\title{
A HISTORIOGRAFIA EM TRABALHO-EDUCAÇÃO como se escreve a história
da educação profissional
}

Maria Ciavatta

Jacqueline Botelho

Jordan Rodrigues dos Santos Lísia Cariello

Marcelo Lima Mônica Rocha Renata Reis Rosângela Rosa Sandra Morais 

A HISTORIOGRAFIA EM TRABALHO-EDUCAÇÃO: COMO SE ESCREVE A HISTÓRIA DA EDUCAÇÃO PROFISSIONAL 



\author{
Maria Ciavatta \\ Jacqueline Botelho \\ Jordan Rodrigues dos Santos \\ Lísia Cariello \\ Marcelo Lima \\ Mônica Rocha \\ Renata Reis \\ Rosangela Rosa \\ Sandra Morais \\ Sânia Nayara Ferreira
}

A HISTORIOGRAFIA EM TRABALHO-EDUCAÇÃO: COMO SE ESCREVE A HISTÓRIA DA EDUCAÇÃO PROFISSIONAL

$1^{a}$ Edição Eletrônica

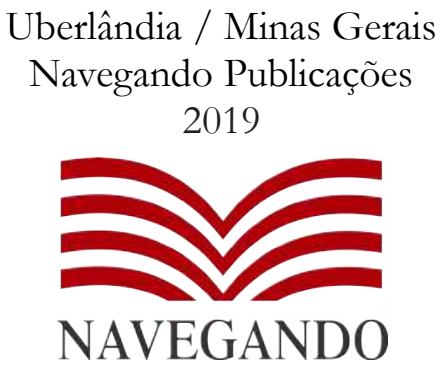




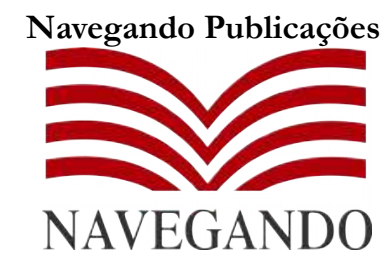

www.editoranavegando.com

editoranavegando@gmail.com

Uberlândia - MG,

Brasil

Copyright (C) by autor, 2019.

M791 - Ciavatta, Maria et al. A historiografia em trabalho-educação: como se escreve a história da educação profissional. Uberlândia: Navegando Publicações, 2019.

ISBN: 978-85-53111-86-2

d.) $10.29388 / 978-85-53111-86-2$

1. Educação 2. Historiografia 3. Trabalho. I. Maria Ciavatta; Jacqueline Botelho; Jordan Rodrigues dos Santos; Lísia Cariello; Marcelo Lima; Mônica Rocha; Renata Reis; Rosangela Rosa; Sandra Morais; Sânia Nayara Ferreira. II. Navegando Publicações. Título.

CDD - 370

$\mathrm{CDU}-37$

Revisão/ Diagramação - Lurdes Lucena

Arte Capa: José Eduardo Fernandes. "Inspirada na obra Passagio de Marcos Duprat".

\section{Índice para catálogo sistemático}

Educação

370 
Navegando Publicações

NAVEGANDO

www.editoranavegando.com

editoranavegando@gmail.com

Uberlândia - MG

Brasil
Editores

\author{
Carlos Lucena - UFU, Brasil \\ José Claudinei Lombardi - Unicamp, Brasil \\ José Carlos de Souza Araújo - Uniube/UFU, Brasil
}

\section{Conselho Editorial}

Afrânio Mendes Catani - USP, Brasil

Alberto L. Bialakowsky - Universidad de Buenos Aires, Argentina. Ángela A. Fernández - Univ. Autónoma de Sto. Domingo, República Dominicana

Anselmo Alencar Colares - UFOPA, Brasil

Carlos Lucena - UFU, Brasil

Carlos Henrique de Carvalho - UFU, Brasil

Carolina Crisorio - Universidad de Buenos Aires, Argentina

Cílson César Fagiani - Uniube, Brasil

Christian Cwik - University of the West Indies, St.Augustine, Trinidad \& Tobago

Christian Hausser - Universidad de Talca, Chile

Daniel Schugurensky - Arizona State University, EUA

Dermeval Saviani - Unicamp, Brasil

Elizet Payne Iglesias - Universidad de Costa Rica, Costa Rica

Fabiane Santana Previtali - UFU, Brasil

Francisco Javier Maza Avila - Universidad de Cartagena, Colômbia

Gilberto Luiz Alves - UFMS, Brasil

Hernán Venegas Delgado - Universidad Autónoma de Coahuila, México

Iside Gjergji - Universidade de Coimbra - Portugal

Iván Sánchez - Universidad del Magdalena -Colômbia

João dos Reis Silva Júnior - UFSCar, Brasil

Jorge Enrique Elías-Caro - Universidad del Magdalena, Colômbia

José Carlos de Souza Araújo - Uniube/UFU, Brasil

José Claudinei Lombardi - Unicamp, Brasil

José Jesus Borjón Nieto - El Colégio de Vera Cruz, México

José Luis Sanfelice - Univás/Unicamp, Brasil

Lívia Diana Rocha Magalhães - UESB, Brasil

Mara Regina Martins Jacomeli - Unicamp, Brasil

Miguel Perez - Universidade Nova Lisboa - Portugal

Newton Antonio Paciulli Bryan - Unicamp, Brasil

Paulino José Orso - Unioeste - Brasil

Raul Roman Romero - Universidad Nacional de Colombia - Colômbia

Ricardo Antunes - Unicamp, Brasil

Robson Luiz de França - UFU, Brasil

Sérgio Guerra Vilaboy - Universidad de la Habana, Cuba

Silvia Mancini - Université de Lausanne, Suíça

Teresa Medina - Universidade do Minho - Portugal

Tristan MacCoaw - Universit of London - Inglaterra

Valdemar Sguissardi - UFSCar - (Aposentado), Brasil

Victor-Jacinto Flecha - Universidad Católica Nuestra Señora de la Asunción, Paraguai

Yoel Cordoví Núñes - Instituto de História de Cuba, Cuba 

A meus filhos e aos alunos que, com suas jovens histórias de vida, me trazem para a realidade de seu tempo. 



\section{AGRADECIMENTOS}

A pesquisa é, por excelência, uma atividade coletiva com momentos fortemente marcados pela imersão individual no âmago dos problemas. Neste percurso, a universidade pública é o lócus da autonomia, da reflexão e da ação que se desdobra na presença dos jovens pesquisadores que, ao participar de um Projeto, constroem seu pensamento, suas pesquisas, teses, dissertações, monografias, e nosso dia-a-dia.

Começo por eles meus agradecimentos nestes cinco anos de convivência, dúvidas e achados importantes na busca de categorias filosóficas, gerais e específicas, da compreensão dos autores estudados e da ampliação de conhecimentos e do pensamento crítico sobre o trabalho e a educação: Ana Cristina de Oliveira, Diogo de Oliveira, Domingos Lima Filho, Gregório Galvão, Júlia Turrini, Lucília Carvalho, Maria Conceição da Silva, Nádia Correa, Rodrigo Lima, Roberta Passos, Samara Morais, Sebastião Gonçalves, Thaís de Moraes, Vitor Bemvindo, além dos coautores deste livro.

Embora o sistema atual de pós-graduação eimpele a nós, pesquisadores e professores da pós-graduação, à competitividade pelos melhores livros e revistas para publicação de nossos textos, toda pesquisa é devedora das ideias que circulam nos coletivos científicos a que pertencemos. São alimentos do espírito investigativo as temáticas que emergem dos estudos e de novas referências de uns e outros, das inquietações teóricas e dos problemas que reconhecem no tecido social.

Assim, por este livro e por muitos estudos que o precederam, agradeço o contínuo aprendizado nos Seminários de Estudo que me desafiam cada mês, no trabalho conjunto com os colegas coordenadores do Grupo THESE - Projetos Integrados de Pesquisas em Trabalho, História, Educação e Educação (UFF-UERJ-EPSJV-Fiocruz): Profs. Gaudêncio Frigotto, Marise Ramos, Lia Tiriba, Eveline Algebaile e Júlio Lima.

Ao Núcleo de Estudos, Documentação e Dados sobre Trabalho e Educação (Neddate) e ao Programa de Pós-graduação em Educação, ambos da Universidade Federal Fluminense, onde o tema do trabalho e da educação avança há três décadas, acompanhando as transformações da sociedade brasileira.

Ao Prof. Marcelo Mustè da Università La Sapienza di Roma por compartir suas aulas de filosofia e sua experiência acadêmica com meu objeto de estudo.

Ao Conselho Nacional de Desenvolvimento Científico e Tecnológico (CNPq) pela Bolsa de Produtividade; pelo suporte institucional, 
docente e acadêmico-científico ao Projeto de Pesquisa "Historiografia em Trabalbo-Educação e o pensamento crítico - Como se escreve a História da Educação Profissional”.

Aos autores que compareceram pessoalmente ou enviaram vídeos e textos ao Colóquio de apresentação e debate dos trabalhos finais da Pesquisa, expondo sua experiência de pesquisadores na elaboração dos livros estudados: Adriana Maria Paulo da Silva, Carmen Sylvia Vidigal de Moraes, Luciano Mendes Faria Filho, Luiz Antonio Cunha, Marcelo Lima, Sílvia Maria Manfredi; aos colegas debatedores e aos coordenadores das mesas: Alessandra Schueller, Angela Tamberlini, Cláudia Alves, Domingos Lima Filho, Eveline Algebaile, Jaqueline Ventura, Júlio Lima, Lia Tiriba, Marise Ramos, Musa Clara Chaves, Olívia Neta, Rebeca Gontijo, Sonia Maria Rummert,

Aos músicos que trouxeram ao Colóquio a musicalidade dos trabalhadores do campo e da cidade: Jordan Rodrigues, Júlio Rocha, Pedro Correia, Sebastião Gonçalves e Zeca Lutier.

A Antonio Carlos por compartilhar, com generosidade, nosso tempo de vida com as exigências da pesquisa.

Rio, julho de 2019

Maria Ciavatta 


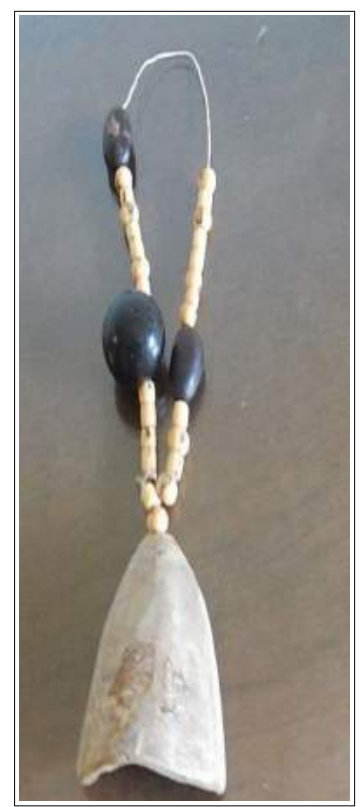

As fontes documentais, à semelhança do colar acreano, são objetos incompletos, instigantes, silenciosos na sua beleza e indeterminação. Cabe aos estudiosos buscar suas referências, suas relações com o mundo real e discursivo, e interpretá-las a serviço do conhecimento crítico aos preconceitos sociais, etnoraciais, de gênero e a toda desumanização e destruição da vida ${ }^{1}$.

\footnotetext{
${ }^{1}$ Acervo pessoal e foto de Maria Ciavatta, Rio de Janeiro, janeiro de 2019. “O pingente, provavelmente, é de coco de praia, a semente escura, maior, é conhecida como 'sabonete', é de uma árvore; a casca desta árvore faz muita espuma que é boa para lavar roupa; a semente escura ovalada é mucuna, boa para adubar naturalmente a terra; a redondinha pequena e 'branca' é semente de açaí (polida); a pequena meio cilíndrica, também clara, provavelmente, é a jarina, o famoso "marfim vegetal"' (E-mail de 08-022019, de Mariana Ciavatta Pantoja, docente, antropóloga da Universidade Federal do Acre, e Mariana Feitosa do Nascimento, matriarca de 89 anos, do povo indígena Kuntanawa, que mora no Rio Tejo, Alto Juruá, Acre).
} 

PREFÁCIO

Gaudêncio Frigotto

APRESENTAÇÃO

Maria Ciavatta

A - HISTORIOGRAFIA EM TRABALHO-EDUCAÇÃO

I - TRABALHO-EDUCAÇÃO - A história em processo

Maria Ciavatta

II - COMO SE ESCREVE A HISTÓRIA DA EDUCAÇÃO

PROFISSIOMAL - Caminhos para a historiografia

Maria Ciavatta

III - HISTÓRIA DA EDUCAÇÃO E DO TRABALHO NO

BRASIL - O livro de Celso Suckow da Fonseca

Sandra Morais e Sania Nayara Ferreira

IV - O PASSADO ESCRAVISTA NO PRESENTE: a Sociologia

histórica de Luiz Antonio Cunha - uma releitura

Maria Ciavatta e Renata Reis

B - TRABALHO E EDUCAÇÃO DE CRIANÇAS POBRES

V - TRABALHO-EDUCAÇÃO DAS CRIANÇAS POBRES NA

PRIMEIRA REPÚBLICA - O livro de Luciano Faria Filho

Rosângela Rosa

VI - O PROTAGONISMO DOS PRETOS E PARDOS NA LUTA

POR ESCOLA NA PRIMEIRA METADE DO SÉCULO XIX - O livro de Adriana Maria Paulo da Silva

Jacqueline Botelho e Mônica Rocha

VII - A RESPOSTA REPUBLICANA AO PROBLEMA DA

INFÂNCIA POBRE - O livro de Milton Ramon de Oliveira

Maria Ciavatta

C - TRABALHO-EDUCAÇÃO DOS TRABALHADORES

VIII - AS CONTRADIÇÕES DO MUNDO DO TRABALHO

NO SISTEMA SENAI - O livro de Marcelo Lima

Jordan Rodrigues dos Santos e Lisia Nicoliello Cariello

IX - HISTÓRIA DA SOCIALIZAÇÃO DA FORÇA DE

TRABALHO EM SÃO PAULO (1873 - 1934) - A contribuição de Carmen Sylvia Vidigal de Moraes

Marcelo Lima e Jacqueline Botelho 
X - RELAÇÕES E TENSÕES ENTRE TRABALHO, ESCOLA 181 E PROFISSIONALIZAÇÃO - O livro de Silvia Maria Manfredi Sandra Morais e Rosângela Rosa

REFERÊNCIAS BIBLIOGRÁFICAS 199

SOBRE OS AUTORES 211 


\title{
PREFÁCIO*
}

\section{Gaudêncio Frigotto ${ }^{1}$}

\author{
A bistória não para de exumar cadáveres. Não há mais trégua à \\ infâmia. $O$ ano esquecido, 1888, é um espectro que ronda. \\ (Juremir Machado da Silva, 2018. p. 486)
}

O livro A bistoriografia em trabalho e educação - como se escreve a bistória da educação profissional resulta de um esforço coletivo de um grupo de pesquisa coordenado por Maria Ciavatta o qual nos ajuda a entender um dos aspectos importantes da luta de classes em nossa sociedade. $\mathrm{O}$ "como se escreve a história da educação profissional” reflete, ao mesmo tempo, a concepção de ser humano, de sociedade, de trabalho e a base epistemológica mediante a qual se desvela ou se mascara as relações sociais que a constituem. Deste modo, consciente ou por condição de classe, este como se escreve é parte da luta de classe.

Os autores e obras selecionadas do livro, os recortes de temas que abarcam e o método de análise nos permitem, num tempo de longa duração, perceber o que se reitera, em diferentes conjunturas, como projeto de educação da classe trabalhadora. O livro engendra, pois, o duplo apreender da história: como processo e como método. Trata-se de, ao percorrer nossa construção histórica como sociedade e como projeto de educação e, no caso em debate, a educação profissional, entender o sentido e a direção das disputas do presente. A coletânea cumpre, assim, o que realça Florestan Fernandes ao expor o sentido de história em processo:

\begin{abstract}
A história em processo é (como foi visto acima) a história dos homens, o modo como eles produzem a sua vida, ligando-se ou opondo-se uns aos outros, de acordo com sua posição nas relações sociais de produção, na sociedade e no Estado, e gerando assim, os eventos e processos históricos que evidenciam como a producão, a sociedade e o Estado se preservam ou se alteram ao longo do tempo. (FERNANDES, 1961, p. 47, grifos do autor).
\end{abstract}

A epígrafe deste prefácio, quer pelo DNA colonizador, quer pelos quase quatrocentos anos de escravidão, quer pela opção de um projeto societário de capitalismo dependente pela classe dominante brasileira, define como a sociedade e o Estado se preservam e qual a concepção de trabalho e de educação profissional buscam reproduzir.

\footnotetext{
*DOI - 10.29388/978-85-53111-86-2-f.1-6

${ }^{1}$ Professor titular em Economia Política da Educação na Universidade Federal Fluminense (aposentado) e, atualmente, Professor Associado na Universidade do Estado do Rio de Janeiro.
} 
Uma particularidade que se expressa na conformação de uma das sociedades mais desiguais do mundo e que tem, portanto, uma concentração de renda e propriedade descomunais mantidas por um duplo mecanismo: a violência de ditaduras e golpes ou mediante artimanhas políticas e jurídicas que anulam os avanços na conquista de direitos sociais e subjetivos formalmente assegurados nas Constituições, em especial a de 1988.

Ao longo do século XX a sociedade brasileira esteve por trinta anos sob as ditaduras de Getúlio Vargas (1937-1946) e a empresarial militar (19641985) e diferentes golpes institucionais. O que ocorreu e vem ocorrendo com a Constituição de 1988, no século XXI, é exemplar para entender os subterfúgios políticos e jurídicos para anular as conquistas da classe trabalhadora no âmbito dos direitos sociais, educacionais, culturais e subjetivos e pela não regulamentação de pontos centrais como os da regulação da mídia empresarial, taxação das grandes fortunas, realização das reformas tributária, política e jurídica. Exemplar, também, para qualificar as disputas, na sociedade, no Estado e na educação profissional, que demarcam as junturas da década de 1990, do período 2003 a 2016 e o que está em jogo a partir de 2019.

O que se denominou de Constituição cidadã, para designar nos marcos da lei os avanços na definição dos direitos sociais e subjetivos, inicia seu desmonte na década de 1990 mediante a adoção das políticas neoliberais no âmbito econômico e educacional. $\mathrm{Na}$ economia, com as privatizações que configuraram a venda do país e o aprofundamento da perda da autonomia e soberania nacionais. No campo da educação com a resistência ao projeto de leis de Diretrizes e Bases da Educação Nacional e o Plano Nacional de Educação que traduziam o espírito dos avanços afirmados na Constituição. O Decreto 2.208/97 oficializa legalmente a dualidade educacional, agora acrescida da diferenciação dentro dos níveis de escolaridade.

Com a ascensão ao poder em 2003 de Luiz Inácio Lula da Silva, por dois mandatos, e de Dilma Rousseff durante um mandato, já que o segundo foi barrado desde o início e, finalmente, impedido por um golpe de Estado, não se trilhou o mesmo rumo na economia e nem na educação, embora sem mudanças estruturais. Um dos pontos altos destes governos foi a política externa com a América Latina e seu papel na criação do Grupo BRICs (Brasil, Rússia, Índia e China e África do Sul), diminuindo a dependência e subserviência ao império Norte Americano. Mas também avanços na distribuição e transferência de renda e investimentos na educação, em especial com criação dos trinta e oito Institutos Federais de Educação Ciência e Tecnologia, com ampla interiorização dos mais de quinhentos campi e a criação e interiorização de dezoito universidades federais.

A revogação do Decreto 2.2008/97 substituído pelo Decreto 5154/04 restabelece a possibilidade da integração da educação profissional à educação básica. O caráter não compulsório desta integração revela a correlação de forças na luta pela direção da educação profissional em três aspectos: a integração 
ou articulação da educação profissional à educação básica, o financiamento e a sua gestão. Diferentes pesquisas, teses e dissertações mostram que esta disputa estava em curso no plano das instituições e da sociedade.

Uma síntese conclusiva possível de sustentar, ainda que possa ter matizes diversos, e suas consequências para o dramático tempo presente a partir do desfecho das eleições de 2018, se expressa nos seguintes desdobramentos:

O golpe de Estado consumado em agosto de 2016 tem como autoria intelectual e política o grupo de forças da década de 1990, em especial do período de oito anos do governo Fernando Henrique Cardoso. A evidência empírica disto está no fato de que os postos-chave do governo golpista foram ocupados por membros daquelas forças que não apenas buscaram completar as reformas de 1990, como as aprofundaram e em aprovação acelerada. A Emenda Constitucional n. 95, as contrarreformas trabalhista e da educação básica e a proposta da contrarreforma da previdência (ainda não aprovada) indicam este aprofundamento. No âmbito educacional liquidou-se com o sentido histórico de educação básica e, na educação profissional, retomou-se, e de forma regressiva, a dualidade do Decreto 2.208/97.

O segundo desdobramento é de que o Golpe de 2016, construído a partir de 2014 já no processo eleitoral, resulta dos acertos, sinalizados acima, dos governos liderados pelo Partido dos Trabalhadores. Mas o impeachment da presidente Dilma Rousseff e a prisão de Luiz Inácio Lula da Silva advêm de seus erros, mormente de ter despolitizado a política e perdido a base social ampla que poderia impedir o golpe e a prisão.

O terceiro desdobramento é a fragorosa derrota nas urnas do grupo golpista do período, sobretudo, do governo Fernando Henrique Cardoso. Este grupo de direita, ao propor-se, a qualquer preço, não deixar Dilma Rousseff governar no segundo mandato e, por casuísmos políticos e jurídicos e apoio, consumar o impeachment e encarcerar o ex-presidente Luiz Inácio Lula da Silva para impedi-lo a concorrer às eleições de 2018 e a sua provável vitória, acabou permitindo a vitória nas eleições de forças majoritárias de extrema direita $^{2}$. E o que é mais perverso é que essas forças derrotadas, do âmbito político, econômico, jurídico e da grande mídia empresarial, por condição de classe, acabam compondo e sustentando o projeto das forças de extrema direita.

O leitor deste livro, pelo que ele revela de nosso processo histórico na relação sociedade, estado e educação da classe trabalhadora e pelo método materialista histórico que orienta as análises, poderá perceber que o presente

\footnotetext{
${ }^{2}$ Para que não caiamos no pastiche destas forças de extrema direita que se elegeram mediante guerra midiática pelo que está se definindo de pós-verdade para a qual não há fatos históricos e, portanto, cria-se e dissemina-se construções discursivas de ódio falseando a realidade, vale a leitura do pequeno livro: Direita e esquerda. Razõos e significados de uma distinção política de Norberto Bobbio (1995). No livro ele caracteriza o sentido histórico de esquerda e direito e a importância de manter esta demarcação, bem como o que catequiza as forças políticas de esquerda, extrema esquerda, direita e extrema direita.
} 
nos traz, agora como farsa, a continuidade de nossa tragédia histórica de exumar cadáveres e que o ano de 1888 continua sendo o espectro que ronda. A farsa assume traços de protofacismo mediante a junção de forças fundamentalistas do campo econômico, político e religioso e que atingem frontalmente a educação pública em todas as suas modalidades.

No campo econômico, os elementos fascistas expressam-se de forma molecular pela aniquilação da esfera pública - único espaço onde se pode garantir direitos universais - e pela adoção das leis de mercado como balizadoras das relações sociais. $\mathrm{O}$ avanço célere nesta direção já se concretizou pelas mudanças constitucionais e contrarreformas nos dois anos de governo golpista, como indicamos acima. O que não se aprovou neste período, a contrarreforma da previdência, passou a ser o tema central e o discurso fetichista de que se não for aprovada o Brasil quebra.

$\mathrm{Na}$ verdade, trata-se de uma proposta que simplesmente acaba com o sistema de proteção social, previdência social, e o futuro das gerações mais novas atuais e das que vêm dependerá da capacidade de cada um fazer a sua previdência mediante a capitalização. Afirmar isso num país onde a renda média mensal é pouco mais de oitocentos reais e que, portanto, a maioria dos brasileiros sobrevive com um salário mínimo, não é apenas cínico, é criminoso.

Um crime, porque significa o que Karl Polany afirma no livro $A$ grande transformação sobre a revogação na Inglaterra em 1984 da lei dos pobres que lhes garantia os bens básicos e a reprodução da vida mediante a criação de "um mercado concorrência de trabalho". Polany conclui que isso representou "a revogação do direito de viver" (POLANY, 2012, p 115). Com Polany podemos afirmar que, se aprovado projeto da previdência e a liquidação dos direitos do trabalho pela proposta da Carteira Verde Amarela, cujo lema claro é ou o direito ou o trabalho, será revogada a lei do direito de viver à maioria do povo brasileiro.

Para que as medidas dos traços fascistas do campo econômico se efetivem necessita-se de um aparato político, jurídico e mediático que o sustente. É neste aspecto que se expressa o fundamentalismo político e onde não se busca o embate de projetos e de ideais com os adversários, mas o objetivo é de aniquilar e eliminar a quem se opunha ao seu projeto e às suas ideias. Este foi o traço de ódio desde a campanha eleitoral e que se prolonga até hoje nas redes sociais. No campo da educação, não por acaso, o que os orienta é a ideologia do Movimento Escola sem Partido, a censura e demonizarão de autores como Paulo Freire e todos os pensadores que se enquadram sob o que denomina de "marxismo cultural". Nesta agenda também está a proposta de retomar a educação moral e cívica e a militarização das escolas.

Por fim, o fundamentalismo religioso, protagonizado pelos adoradores de bezerros de ouro, nos termos de hoje, as seitas que fazem da religião um mercado - as merco-igrejas. O ponto central deste fundamentalismo é de sobrepor o mundo privado à esfera pública e desautorizar a ciência e sobrepor a ela 
a metafísica do criacionismo. Um retrocesso à Idade Média. Isto em nome da moralidade e dos valores da família. Daí resulta, também, a censura ou a incriminação para aqueles que divulgam o que denominam, sem definir, ideologia de gênero.

O livro buscou, nas obras e temas estudados, nos trazer diferentes formas de análise da educação profissional desde nossa fundação como sociedade colonial e escravocrata até a primeira década do Século XXI. As obras, autores e temas analisados refletem o mover da história da sociedade, do Estado e a conformação da educação profissional ligando-se ou opondo-se uns aos outros, de acordo com sua posição nas relações sociais de produção. Por isso refletem, também, o sentido da luta de classe e o que, ao fim, prevaleceu. É a continuidade que se reitera pela violência de ditaduras e golpes, é o estigma do DNA colonizador e escravocrata nas concepções e políticas de formação da classe trabalhadora.

As análises das obras e temas que compõem o livro não tratam dos acontecimentos do tempo de duração que se manifestam em 2013 e se materializam no golpe de Estado de 2016 e da eleição de forças sociais com um projeto societário de extrema direita. Entretanto o sentido das continuidades, agora num contexto de crise do sistema capitalista, o livro nos permite perceber que o que ocorreu não é fruto do acaso. A abertura da apresentação de Maria Ciavatta, autora e coordenadora do livro, não somente indica que sua produção foi efetivada no contexto de acontecimentos que se processaram e se processam a ferro quente, mas o que se desenha como projeto de poder na anulação de direitos e do Estado democrático de direito.

O livro, pela concepção de história como processo inserido na luta de classes e o método materialista histórico como ferramenta para desvelar o que está subjacente aos fatos e acontecimentos, tem um denso caráter formativo que não se restringe ao campo que pesquisa a relação trabalho e educação. Isto numa dupla direção: na compreensão do sentido e da verdade histórica e, a partir desta compreensão, a interpelação de organizar forças sociais capazes de barrar e reverter o projeto de poder em curso e, no médio e longo prazo, a sociedade de classe que o produziu. Esta tarefa é crucial, pois como nos indicam Marx e Engels: "as ideias não podem executar absolutamente nada. Para a execução das ideias são necessários homens que ponham em ação uma força prática. (MARX e ENGELS, 203, p.137, grifos dos autores).

\section{Referências Bibliográficas}

BOBBIO, Norberto. Direita e esquerda: razões e significados de uma distinção política. São Paulo, Editora da UNESP, 1995.

DA SILVA, Juremir Machado. Raízes do conservadorismo brasileiro: a abolição na imprensa e no imaginário social. Rio de Janeiro, Civilização Brasileira, 2018, p.436. 
FERNADES, Florestan. Marx/Engels: História. Rio de Janeiro, Civilização Brasileira, 1961.

MARX, Karl e ENGELS, Friedrich. A sagrada família. São Paulo, Boitempo, 2003.

POLANY, Karl. A grande transformação. 2. ed. Rio de Janeiro, Elsivier, 2012. 


\section{APRESENTAÇÃO*}

O que é de dentro é o fora. E o fora é o mais dentro. Não só a história traz a marca dos indivíduos que a fazem. Mas também é interiorizada pelos individuos que a vivem".

(Paulo Leminski) ${ }^{1}$

Escrevo esta apresentação sob a inquietação gerada no período que deu sinais e contrassinais de turbulências políticas em 2013; arrastou-se até o impeachment de 2016 e a ruptura do sistema democrático sob a ação de um legalismo inverossímil; e, nas eleições de 2018, retomou décadas de autoritarismo e de ameaças aos direitos humanos e sociais prometidos pela democracia. Debruço-me sobre as ideias de "Pós-verdade - A nova guerra contra fatos em tempos de fake News" do livro de Matthew D'Ancona ${ }^{2}$ para buscar entender, no espaço-tempo da sociedade brasileira, a indiferença, a resignação, o conforto das próprias imagens e emoções "curtidas" por dezenas, senão milhares de seguidores no Facebook e em outras mídias sociais. Prevalecem a aceitação do ódio, a banalização da violência, o anti-intelectualismo, a descrença no conhecimento da verdade, salvo as que coincidem com os próprios sentimentos.

E através dos escritos, aqui apresentados em alguns de seus aspectos, chego ao passado da sociedade brasileira. Este livro poderia ter o título de "memórias de um país desalmado", tantos são os maus sentimentos, a crueldade, as perversidades e os tratamentos desumanos registrados em seus textos por alguns autores. Não obstante escreverem a história da educação profissional no Brasil, com as ressalvas da linguagem acadêmico-científica, os acontecimentos narrados e documentados denunciam a sociedade hierarquizada segundo os padrões do trabalho escravo.

Foram quatro séculos de escravidão, primeiro, a tentativa de escravizar os índios que foram privados, de suas terras, mas não submetidos; depois, a escravização ampla de negros, homens e mulheres trazidos da África. Com requintes da submissão estruturada em torno de fortes reis e imperadores, interiorizada nos países de origem, submeteram-se, não sem resistências, a todo tipo de apropriação de seus corpos e de suas vidas para o trabalho dito manual.

A inferioridade do trabalho manual é o pano de fundo da preparação para o trabalho destinado a eles e, subsequentemente, após a Lei da Abolição (1888) e depois da Proclamação da República (1989), à toda a população brasileira pobre. Às vezes explícito, outras disfarçado sob artifícios ideológicos, o

${ }^{*}$ DOI - 10.29388/978-85-53111-86-2-f.7-10

${ }^{1}$ LEMINSKI, Paulo. Vida. Cruz e Souza, Bashô, Jesus e Trotski - 4 biografias. São Paulo: Companhia das Letras, 2013, p. 246.

${ }^{2}$ D’ANCONA, Matew. Pós-verdade. Barueri, SP: Foro Editorial, 2018. 
tratamento do trabalho manual, como inferior, discrimina a massa trabalhadora, separando-a para as duas orientações principais da educação, a acadêmicohumanista e científica, com vistas ao ensino superior, e a profissional manual, técnica ou tecnológica instrumental.

Muitos autores revelaram em seus estudos, a partir da divisão do trabalho, esta divisão de classes sociais e da destinação educacional diferente entre os filhos das elites e aqueles das classes trabalhadoras. São exemplares o trabalho de Luiz Antonio Cunha ${ }^{3}$ sobre as duas redes educacionais, a primáriaprofissional e a secundária-superior; ou de Acácia Kuenzer ${ }^{4}$ reiterando, em seus escritos, o dualismo educacional; e de Gaudêncio Frigottto, ${ }^{5}$ detalhando "como se faz pelas mãos a cabeça do trabalhador".

É o Brasil que emerge sempre do passado para moldar o presente. Não trato do novo. O que é inaugural, neste livro, é o objetivo de um estudo sistemático de como diferentes historiadores pesquisaram e escreveram sobre a educação profissional, com detalhes sobre o enfoque teórico, a documentação utilizada e sobre a discriminação encarnada na estrutura da sociedade brasileira, oficializada pelo Estado e implementada pelos governos e outras instituições para a educação dos mais pobres. Críticas, oposições sempre houve, mas a força hegemônica dos interesses patrimoniais e econômico-financeiros e os preconceitos sociais e raciais sempre prevaleceram sobre as iniciativas de transformação.

Devemos acrescentar que, embora o campo da História da Educação seja amplo e conceituado, são escassos os trabalhos sobre a história do trabalho e da educação ${ }^{6}$. Prevalecem os estudos sobre cultura escolar, gênero, escolarização, currículo, reformas educacionais, escolas, práticas e representações, legislação educacional, intelectuais da educação brasileira, escola pública, período republicano, Estado Novo e outros?

\footnotetext{
${ }^{3}$ CUNHA, Luiz A. Ensino médio e ensino técnico: de volta ao passado. Educação e Filosofia, v. 12, n. 24, p. 65-89, jul.dez. 1998; CUNHA, Luiz A. Uma leitura da escola capitalista. Rio de Janeiro: Achiamé, 1982.

${ }^{4}$ KUENZER, Acácia. Ensino médio. Construindo uma proposta para os que vivem do trabalho. São Paulo: Cortez, 2000.

${ }^{5}$ FRIGOTTTO, Gaudêncio. Fazendo pelas mãos a cabeça do trabalhador. Cadernos de Pesquisa, n. 47, p. 38-45, nov. 1983.

${ }^{6}$ Entre outros, podemos citar no campo da história da educação: LOMBARDI, José C.; SAVIANI, Dermeval. (orgs.). Marxismo e Educação. Campinas: Autores Associados / HISTEDBR, 2005; MORAES, Carmen S. V. Instrução "popular" e ensino profissional: uma perspectiva histórica. In: VIDAL, Diana et al. (orgs.). Brasil 500 anos. Tópicas em História da Educação. São Paulo: Editora da USP, 2001, p. 169-204; GIGLIO, Célia M. B. Impressos operários, leitores e práticas de resistência. In: WARDE, Miriam. Temas de História da Educação. Contemporaneidade e Educação, IEC, ano V, n. 07, p. 71-92, 1º. Sem. 2000.

${ }^{7}$ Uma releitura analítica dos Clássicos da Educação Brasileira está em Xavier (2010) que contempla os autores que escrevem sobre a Escola Nova, a Escola Ativa, a cultura brasileira, o método pedagógico dos jesuítas e outros.
} 
Temos por hipótese que o divisor de águas são as opções políticas e teóricas que, na escrita da história, são polêmicas, primeiro, por tratar da estrutura de classes e da desigualdade social no Brasil; segundo, pela interpretação crítica à luz da contradição capital e trabalho que denuncia as relações sociais de produção capitalistas. Não se pode falar do trabalho no Brasil, sem tratar das relações escravistas e de sua permanência econômica, cultural e ideológica, alicerçada nas grandes fortunas latifundiárias, industriais e financeiras. Através da produção industrial, agroindustrial, de serviços, e da grande imprensa e TV, os grupos hegemônicos comandam uma economia financeirizada a serviço das classes abastadas, do consentimento interessado das classes médias, opondose à elevação dos níveis de vida e de educação universalizados para toda a população.

Com algumas questões iniciais e existenciais, estabelecemos um diálogo que pretende trazer para a pesquisa no campo do materialismo histórico a exigência da fundamentação na história. Quase invisível para muitos, que examinam a sociedade capitalista sob o prisma de crítica à economia política, a história é a produção social da existência como reiteram Marx e Engels na Ideologia Alemä $\tilde{a}^{8}$.

No campo específico de estudos sobre Trabalho-Educação, é básico para os pesquisadores, ir à raiz da exploração do trabalho nas sociedades capitalistas, através da crítica à economia política, à contradição capital e trabalho. Mas são poucos os que se dedicam a ir além da sedutora teoria marxista, e descer aos meandros da empiria, incluindo fontes de arquivos e da concepção da história em Marx. Significa buscar a historicidade dos dois campos de estudo, do trabalho e da educação e de sua expressão como unidade, TrabalhoEducação, na educação profissional, técnica, e tecnológica, na educação de crianças, de jovens e de adultos trabalhadores.

Os autores selecionados para a pesquisa são nomes reconhecidos pela sua contribuição ao conhecimento histórico sobre como a teoria toma forma na prática educacional dos sistemas de ensino, das escolas e de movimentos sociais. São autores que escrevem sobre a história da educação profissional, selecionados em diversas vertentes historiográficas, a factual, a cultural e o pensamento crítico de base marxista.

Os artigos apresentados, no livro, sintetizam os principais conceitos e os fundamentos teórico-metodológicos dos estudos desenvolvidos pelo Projeto de Pesquisa "A Historiografia em Trabalho-Educação e o Pensamento crítico. Como se escreve a História da Educação Profissional"”.

A reflexão teórica partiu da escrita da história pelos "historiadores de ofício" e/ou historiadores da educação, assim como dos fundamentos do materialismo histórico na área de pesquisa Trabalho-Educação. Foi realizada a análise de oito autores brasileiros que escrevem sobre a história dos fenôme-

\footnotetext{
${ }^{8}$ MARX; ENGELS. A ideologia alemã (Feuerbach.) São Paulo: Ciências Humanas, 1979.

${ }^{9}$ Proc. CNPq n. 306286/2012-2. Bolsa de Produtividade 1A, (março/2013 a fevereiro/2018),
} 
nos relativos ao trabalho e à educação, a maioria com foco específico na educação profissional.

O livro divide-se em três partes: a primeira trata da unidade do termo e dos fundamentos teórico-metodológicos da história em processo e da historiografia em Trabalho-Educação; completa-a o estudo da obra de Celso Suckow da Fonseca e de Luiz Antonio Cunha, que tratam dos sistemas de educação profissional, seus primórdios e a implantação da educação profissional no sistema federal de ensino profissional, industrial e técnico.

A segunda parte analisa os trabalhos de Luciano Mendes Faria Filho, de Adriana Maria Paulo da Silva e de Milton Ramon de Oliveira, sobre o trabalho e a escolarização de meninos pobres, brancos, pretos e pardos, as instituições de assistência educativa e de trabalho para "menores desvalidos" no campo e na cidade.

$\mathrm{Na}$ terceira parte, os autores estudados são Marcelo Lima, Carmen Sylvia Vidigal de Moraes e Sílvia Maria Manfredi que escrevem sobre a educação profissional no Sistema SENAI, sobre a socialização da força de trabalho no início do século XX e a formação para o trabalho em diferentes espaços da sociedade civil, iniciativas do Estado, dos empresários e das organizações populares e sindicais.

Os textos elaborados foram apresentados durante o Colóquio "Historiografia em trabalho-educação - Como se escreve a História da Educação Profissional" realizado na Faculdade de Educação da Universidade Federal Fluminense, Niterói, RJ, nos dias 8, 9 e 10 de novembro de 2017. Foram objeto de debate com a participação dos autores dos livros analisados (pessoalmente, em vídeo ou por escrito), e debate com historiadores e pesquisadores da área Trabalho-Educação ${ }^{10}$.

Estes artigos não fecham um ciclo de estudos. São como portas que pretendem abrir-se ao debate e ao reconhecimento da contribuição dos autores selecionados e de sua análise crítica pelos pesquisadores envolvidos no projeto. Deixam em aberto outros autores / historiadores que o tempo-espaço desta pesquisa não permitiu incluir.

Como expressei anteriormente, meus agradecimentos são muitos, a muitas pessoas e instituições. Ao longo do intenso processo coletivo, foram tantas as inquietações teóricas e políticas que ampliaram meus caminhos do conhecimento.

Rio de Janeiro, julho de 2019

Maria Ciavatta

\footnotetext{
${ }^{10}$ Para acesso à íntegra das apresentações e debates, ver o vídeo "Historiografia em TrabalhoEducação - Como se escreve a História da Educação Profissional. Colóquio”. Dir. de MARIA CIAVATTA e ROSÂNGELA ROSA. Niterói: UFF, 2019.
} 


\section{A - HISTORIOGRAFIA EM TRABALHO-EDUCAÇÃO}





\title{
I \\ TRABALHO-EDUCAÇÃO - A história em processo ${ }^{*}$
}

Maria Ciavatta

\begin{abstract}
"Quando o sistema educativo não se apoia na consciência histórica de si mesmo, dificilmente pode dar essa consciência ao povo ao qual serve. Quando o sistema educativo não é nutrido pela pesquisa científica com esta dimensão, ele não consegue assumir sua historicidade". (Ivan Nuñez).
\end{abstract}

\section{Introdução}

Quando falamos sobre Trabalho-Educação como a história em processo, temos por base Marx e Engels (1979) e sua concepção revolucionária de história, ao afirmar que o fato histórico fundamental é a existência humana ao prover a todas as suas necessidades. O segundo fato histórico e que, para viver e atender às suas necessidades de sobrevivência, os seres humanos criam outras necessidades, como os instrumentos de trabalho e as diferentes formas de se relacionar com a natureza para produzir os meios de vida.

Coloca-se aqui a questão do trabalho, de um agir tanto em relação à produção material, como à espiritual. Lukács (1978) fala em um "pôr teleológico" do trabalho, o fim ou finalidade, um agir direcionado a satisfazer necessidades. (p. 6). A história deixa de ser uma coleção de fatos mortos, consumados, como nos empiristas, ou o relato dos grandes feitos de reis, príncipes, imperadores, para ser o processo real da vida humana (CIAVATTA, 2009, p. 49$55)$.

O terceiro fato histórico fundamental "é que os homens, que diariamente renovam a sua própria vida, começam a criar novos homens, a procriar: é a relação entre homem e mulher, entre pais e filhos, a família" (MARX; ENGELS, id., p. 41-42). Ao trabalhar e fazer história, o ser humano produz objetos, fenômenos, conhecimentos e sociabilidade com os demais².

${ }^{*}$ DOI - 10.29388/978-85-53111-86-2-f.13-30

${ }^{1}$ Este tema foi apresentado de modo preliminar, no Seminário de Produção Científica do Gru po THESE - Trabalho, História, Educação e Saúde (UFF-UERJ-EPSJV-Fiocruz), Rio de Janeiro, 4, 5 e 6 de dezembro de 2017. O texto é uma versão ampliada de alguns aspectos do tema, publicado em Trabalho Necessário, n. 32, 1‥ Sem. 2019. Agradecemos a Marise Ramos seus comentários à análise da questão.

${ }^{2}$ No "Fetichismo da mercadoria: seu segredo", Marx (1980) se refere a esta tripla capacidade do ser humano, apropriada pelo sistema capital, como a alienação do produto, do conhecimento e da sociabilidade que se gera no trabalho (p. 79 e ss.). 
Na obra de Marx, o método de produção do conhecimento histórico se revela na construção do objeto. Para Labastida (1983), estabelecer o objeto da história implica uma dupla problemática, a uma só vez, ontológica e gnosiológica. Marx (1977) dá exemplo clássico da população, um todo caótico, abstrato, se não forem observadas as classes sociais, a divisão do trabalho, o trabalho assalariado, o capital etc. que compõem as diversas populações. Sua reconstrução histórica, no nível do pensamento, exige a observação das mediações, das contradições e determinações que constituem a totalidade social de cada população no nível real (de um país, região, cidade, bairro, etc.) (p. 228 e ss.).

É esta a complexidade básica da visão de realidade e de conhecimento que dá vida e forma ao materialismo histórico e dialético. Ele foi elaborado por Karl Marx em sua extensa obra e tem uma entrada restrita no Brasil. Leandro Konder (1984) traça um panorama da entrada das ideias de Marx no Brasil.

Aqui, desde o final do século passado, o nome de Marx aparece em alguns pensadores (a exemplo de Tobias Barreto, 1839-1889), na ironia de Machado de Assis (1839-1908), em um artigo de Euclides da Cunha (1871-1939) citando O Capital. Mas "Na passagem do século [XIX para XX], o incipiente movimento operário já permitia o acolhimento e a difusão no Brasil das concepções da Associação Internacional dos Trabalhadores (ou simplesmente, Segunda Internacional) [...]" e "núcleos organizados de propagandistas do socialismo [...]" (KONDER, id., p. 29-30).

Konder destaca as dificuldades para se chegar a conhecer o pensamento de Marx naquelas primeiras décadas da República. Seus escritos chegaram com a criação do Partido Comunista do Brasil (PCB) em 1922. A despeito divulgação restrita de textos de Marx, nos anos 1930, as vozes da direita "passam a se ocupar dele com irritação crescente" (id., p. 33), seguindo-se períodos de abertura breve e de repressão aos comunistas.

Importa para nossa análise que as pequenas possibilidades de difusão e avanço político das ideias marxistas foram sob o patrocínio da União Soviética, sob Stalin (1878-1953). Não obstante a leitura de Marx de um grupo de intelectuais ${ }^{3}$ a partir de 1958, "sem os percalços de uma ótica imediatista e reagindo contra a pressão de tipo 'instrumentalizador"' (id., p. 38), sempre houve os limites intelectuais impostos pela hegemonia das classes dominantes conservadoras, desde a Colônia até os dias de hoje ${ }^{4}$. E atribuo a entrada limitada

\footnotetext{
${ }^{3}$ Konder cita, entre outros, Octavio Ianni, José Arthur Giannotti, Rui Fausto, Michel Lowy (id., p. 38).

${ }^{4}$ Diferente da Europa que criou universidades já no século XII, de países da América Latina que as criou no século XVI (Peru, República Dominicana, México), o Brasil criou, em nível federal, por um agregado de faculdades, a Universidade do Rio de Janeiro, pela Lei n. 13.343 de 07/09/1920. Mas o regime universitário somente se fez presente pelo Estatuto das Universidades Brasileiras, Decreto 19.851 de 11/04/1931, quando reorganizou-se a Universidade do Rio de Janeiro que veio a se tornar a Universidade do Brasil (ROMANELLI, 1978, p. 132-33).
} 
desta polêmica teoria também à permanência dos limites nativos da interpretação instrumental e economicista do materialismo histórico.

Cabe aqui lembrar um aspecto que se combina com os anteriores, é a divulgação também tardia, apenas em 1933, da Ideologia Alemã (MARX; ENGELS, 1979). Concluída em 1846, a obra, semiacabada, trata da importância da ideologia e da consciência, da divisão do trabalho, da importância de transformar o mundo, mas não apenas. Seu foco inicial é a concepção de história como a produção social da existência.

Os autores são claros e diretos na concepção de história que supera a visão tradicional da história factual, linear, dos grandes feitos dos grandes homens, das elites, dos reis, dos imperadores, dos príncipes e de seus generais nas intermináveis guerras de poder e de sacrifício dos povos. A história é a vida de todos nós:

O primeiro pressuposto de toda a existência humana e, portanto, de toda a história, é que os homens devem estar em condições de viver para poder "fazer história" [...]. A história nada mais é do que a sucessão de diferentes gerações, cada uma das quais explora os diferentes materiais, os capitais e as forças de produção a ela transmitidas pelas gerações anteriores (id., p. 39 e 70).

O processo histórico da afirmação do campo Trabalho-Educação nunca foi simples, pelas controvérsias existentes em suas bases teóricas e pela limitada tradição marxista no campo da educação. Também Marx não tratou a educação sistematicamente como seus temas básicos relativos ao sistema capital. Mas quando o tratou, dá indicações claras sobre a relação entre o trabalho e a educação:

Do sistema fabril, como expõe pormenorizadamente Robert Owen, brotou o germe da educação do futuro que combinará o trabalho produtivo de todos os meninos além de uma certa idade com o ensino e a ginástica, constituindo-se em método para elevar a produção social e de meio de produzir seres humanos plenamente desenvolvidos (MARX, 1980 , p. 554, grifo nosso).

Foi profícuo o recurso aos intelectuais e à produção científica de outros países (tais como a França, Itália, México, Argentina), tão logo a Ditadura começou a definhar no final dos anos 1970, o autoritarismo imerso nas próprias contradições (haja vista a Greve do ABC Paulista, vitoriosa em 1978).

Apesar de estar ancorado nas pesquisas teóricas e empíricas, apresentadas e discutidas nas reuniões anuais do GT Trabalho-Educação da ANPEd, a história e a historicidade do materialismo histórico não era um tema para debate, salvo alguns trabalhos, a exemplo de pesquisas de Paolo Nosella e Ester Buffa. As condições adversas das relações laborais dos trabalhadores, as lutas 
pela democratização do país, a instabilidade das políticas para a relação entre o trabalho e a educação sempre forma lidas e analisadas à luz da crítica à economia política, sem a qual não é possível entender as contradições entre o capital e o trabalho.

A questão adormecida, mas não esquecida em nossas análises de temas relativos à relação entre o trabalho e a educação, foi trazida por um dos intelectuais das ciências sociais, o Prof. Hugo Zemelman ${ }^{5}$ nos idos de 1990. Seriam "trabalho e educação" uma unidade semântica e científica? Pode-se entender que os dois termos se conjugam para designar um fenômeno único? Os dois nomes constituiriam uma unidade epistemológica?

Estando neles presentes, tanto pensamentos e práticas do campo do trabalho, como do campo da educação, poderia Trabalho-Educação estar designando fenômenos tão amplos e complexos como trabalho manual, trabalho intelectual, trabalho simples, trabalho complexo, trabalho rural, trabalho urbano, trabalho agrícola, trabalho industrial, trabalho infanto-juvenil, trabalho precário, trabalho escravo e outras formas de trabalho? Ou, no campo da educação, poderia designar as relações do trabalho com a educação, tais como educação profissional, formação profissional, ensino industrial, ensino técnico, educação tecnológica, educação de trabalhadores etc.?

Hoje, nesta segunda década do século XXI, o amadurecimento do campo da pesquisa nas ciências sociais e em educação permite avançar na busca de resposta à questão. Neste texto procuro discutir como os dois termos, trabalho e educação, ambos substantivos, nos últimos trinta anos, no Brasil, desde os primeiros estudos sobre Educação e Trabalho, têm sido assumidos como um campo de investigação científica.

Semanticamente, independentes, têm, no entanto, servido aos pesquisadores para identificarem um conjunto de questões relacionadas à educação e ao trabalho, sob o pressuposto implícito de que constituem uma unidade semântica, Trabalho-Educação. Quero trazer à discussão alguns argumentos sobre sua unidade do ponto de vista, ontológico, epistemológico, histórico e educacional.

\section{A questão ontológica de Trabalho-Educação}

O uso do termo ontologia requer alguma explicitação. Etimologicamente, a ontologia é o estudo do ser. $\mathrm{O}$ termo remete à metafísica ( $\mu \varepsilon \tau \alpha \varphi \cup \sigma \omega \dot{\eta})$, também chamada de "filosofia primeira", o que está além da física, da matemática, das ciências particulares na concepção filosófica de Aristóteles, (FRAILE, 1956, p. 420 e ss.). É a concepção do ser na sua máxima gene-

\footnotetext{
${ }^{5}$ Hugo Zemelman, sociólogo chileno, professor titular de El Colegio de México, foi professor visitante do Programa de Pós-graduação da UFF (Universidade Federal Fluminense) no Seminário Permanente de Produção do Conhecimento para o Mestrado e o Doutorado, em 1992/93.
} 
ralidade, extensiva a todos os seres. O termo é retomado por outros autores para o estudo do ser enquanto ser.

O termo ontologia também expressa uma concepção de ser, e está presente nos filósofos gregos, Aristóteles, Platão, em Tomás de Aquino (século XIII) e outros filósofos modernos, a exemplo de Kant, Hegel, Heidegger. É sempre uma referência ao estudo do ser enquanto tal. Passa-se do plano lógico, do argumento, das definições, para o plano da existência objetiva do ser na realidade exterior ao pensamento.

No materialismo histórico, destaca-se a contribuição de Lukács que dá ao termo ontologia o sentido dialético, com base em Hegel e em Marx. Enquanto na metafísica, o ser é, e não pode não ser ao mesmo tempo, na dialética, o ser é e não é ao mesmo tempo, porque constitui-se no movimento, na permanente transformação. A concepção ontológica do ser social, presente na obra de Marx, mas não claramente teorizada, tem em Lukács uma demorada e complexa elaboração. É uma concepção de ontologia histórico-materialista. Falar sobre a ontologia do ser social, é dizer como o ser humano se constitui enquanto tal.

$\mathrm{Na}$ conferência, síntese de seu pensamento, "As bases ontológicas do pensamento e da atividade do homem", Lukács ${ }^{6}$ (1978) critica o idealismo e o neopositivismo, trata da existência do ser social com base no trabalho, atividade fundante, "base dinâmico-estruturante de um novo tipo de ser", o ser humano (p. 4). O ser humano age através de uma cadeia de mediações que é posta em movimento para produzir a vida,

[...] transformando a natureza e a sociedade, quanto os homens que nela atuam, as suas relações recíprocas etc. [...]. Com o trabalho, portanto, dá-se ao mesmo tempo - ontologicamente - a possibilidade de seu desenvolvimento superior, do desenvolvimento dos homens que trabalham. (p. 5).

O autor destaca a presença da consciência, do por teleológico, como a ideação que está presente em toda ação humana, "o animal tornado homem através do trabalho, como um ser que dá respostas". A ontologia do ser social implica a dialética da liberdade e da necessidade: "Precisamente, essa ligação do reino da liberdade com sua base sociomaterial, com o reino da necessidade, mostra como a liberdade do ser humano seja o resultado de sua própria atividade" (id., p. 15).

É uma concepção ancorada na categoria da totalidade, nas mediações e nas múltiplas determinações sociais que a constituem. Completa sua compreensão, a categoria da particularidade, desenvolvida por Lukács, com base em Hegel (CIAVATTA, 2014), conforme expõe Chasin (1982) ${ }^{7}$ :

\footnotetext{
${ }^{6}$ Gyorgy Lukács, filósofo, crítico literário e historiador húngaro (1885-1971).

${ }^{7}$ J. Chasin (1937-1998), filósofo brasileiro.
} 
"Em síntese, se a ontologia é o estudo do ser concreto existente, a categoria da particularidade é o acesso a ele, na exata medida que ela é um "campo de mediações"; mediações enquanto cadeia viva entre a singularidade e a universalidade [...]" (p.59, grifo do autor $)^{8}$.

O estudo dos fenômenos do campo Trabalho-Educação, como ciência do ser social, exige, a exemplo da obra de Marx, uma observação cuidadosa e repetida dos fatos, dimensões espaço-temporais, qualitativas e quantitativas, tendo em vista uma determinada objetividade no trato com a realidade que não se deixa apreender apenas pela observação dos aspectos aparentes. Os fenômenos correntes de Trabalho-Educação, expressos na educação artesanal, profissional, técnica e tecnológica não se esgotam no senso comum descritivo, nem nos argumentos empresariais, viabilizados pelas burocracias governamentais.

Há que se buscar a essência, a interioridade que constitui a dialética do ser social ou sua totalidade social; é o lado mais profundo, mais oculto que apenas pode ser captado pela reflexão que vai além do imediatamente perceptível (KOSIK, 1976; CIAVATTA, 2009). Lukács não se estende, nesta reflexão, sobre as formas históricas do trabalho, sobre o fenômeno da alienação do produto, do conhecimento e da sociabilidade gerado pela apropriação privada do tempo de trabalho no sistema capital, mas sinaliza: "só quando a humanidade tiver superado qualquer caráter coercitivo de sua própria autoprodução, só então terá sido aberto o caminho social da atividade humana como fim autônomo" (id., p. 16).

\section{Trabalho-Educação: uma categoria epistemológica}

A epistemologia permite situar o campo de estudos em que se coloca a questão da construção da verdade no campo científico de Trabalho-Educação. No Dicionário Básico de Filosofia de Hilton Japiassú e Danilo Marcondes (1996), lê-se: "Segundo os países e os usos, o conceito de 'epistemologia' serve para designar, seja uma teoria do conhecimento (de natureza filosófica), seja estudos mais restritos, concernentes à gênese e estruturação das ciências" (p. 85). Neste caso, trata-se de entender a estruturação semântica e filosófica dos estudos sobre a relação entre o trabalho e a educação, dois termos gerais para designar uma gama de fenômenos teóricos e empíricos articulados.

Este campo de pesquisa, como toda investigação científica, supõe uma concepção de realidade, de categorias e de conceitos ${ }^{9}$ para tratar teórica e empiricamente, o objeto de estudo. Falo em concepção de realidade no sentido de que todo pesquisador tem uma concepção de mundo, de ser humano e

\footnotetext{
${ }^{8}$ Para maior detalhamento da questão, v. Ciavatta (2009).

${ }^{9}$ Esta seção tem por base Ciavatta (2017a); uma análise mais detalhada do tema está no artigo

"Como se escreve a história da educação profissional" neste livro.
} 
de cultura dos quais participa por nascimento e por experiência de vida (tempo-espaço).

$\mathrm{Na}$ língua portuguesa, categoria e conceito são termos utilizados quase indistintamente nos trabalhos científicos, podem até ter o mesmo significado, enquanto termos que se referem a algum atributo dos seres. Mas também podem servir a uma ordenação mais precisa desses atributos, incluindo os epistemológicos.

Categorias e conceitos são questões fundamentais para o entendimento do próprio conhecimento que se pretende produzir. Ambos os termos lidam com objetos de estudo visíveis e invisíveis. Tanto os objetos e fenômenos visíveis quanto os invisíveis ou de pensamento, são seres materiais ou mentais (afetivos, emocionais, intelectuais etc.) em situação de relação com outros tantos seres. Podem designar conteúdos de ordem geral, quanto de natureza específica.

Os conceitos, por sua etimologia (conceptus, concepção), dão conteúdo teórico aos termos, a ex. de economia, sociedade, classe, cultura etc. Os conceitos gerais devem servir ao universo amplo de todos os seres e podem ser objeto de estudo das ciências sociais, da história e da historiografia. As catego-

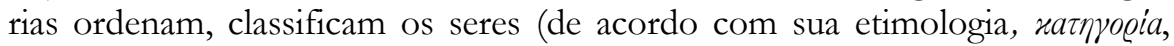
atributo), a exemplo de animais vertebrados e invertebrados, seres minerais, vegetais ou animais etc., nas ciências sociais, quando falamos nas classes sociais, classes de alta, média ou de baixa renda. Quais categorias são gerais e quais são específicas é uma questão do universo de seres (fenômenos, sujeitos, objetos) aos quais se referem.

$\mathrm{Na}$ pesquisa sobre "Como se constroem as categorias" (CIAVTTA, 2012) em história da educação profissional, precisei de instrumentos analíticos com densidade teórica, explicativos do que é história e historiografia, trabalho e educação e outros termos afins, tendo como referencial teórico principal a concepção marxista de mundo, de ser humano e de sociedade. Do ponto de vista epistemológico, Trabalho-Educação é uma categoria ou um conceito, cuja epistéme (verdade, saber, conhecimento) tem por base objetos e acontecimentos externos ao termo linguístico, que constituem a realidade de onde se parte para a elaboração teórica da unidade dos termos.

Outro aspecto conceitual importante para a unidade epistemológica de Trabalho-educação é o conjunto dos processos sociais ou as mediações históricas que constituem sua totalidade social e permitem falar em conhecimento social e cientificamente produzido. Como ensina Marx (1979), o exemplo da população, "síntese de múltiplas determinações" [...] é um resultado, e não um ponto de partida, apesar de ser o verdadeiro ponto de partida e, portanto, igualmente o ponto de partida da observação imediata e da representação." (p. 229). A totalidade social construída não é uma racionalização ou modelo explicativo, mas um conjunto dinâmico de relações que passam, necessariamente, pela ação dos sujeitos sociais. Seus referentes são históricos, quais sejam, ma- 
teriais, sociais, mentais, morais ou afetivos, de acordo com as relações que constituem determinada totalidade (CIAVATTA, 2016, p. 210).

\section{A historicidade de Trabalho-Educação}

Quando falamos na historicidade de Trabalho-Educação, fazemos apelo às categorias tempo-espaço, fontes, sujeitos sociais presentes neste tema de estudos. A pesquisa genérica, sem marcos espaço-temporais, resvala facilmente para a metafísica. $\mathrm{O}$ mundo da história, em uma visão dialética, é o mundo do movimento, da transformação que pauta a vida tal qual a conhecemos como humanidade. No materialismo histórico é o mundo do ser social, dos homens e mulheres em sociedade, agindo, produzindo as próprias condições de vida, nas circunstâncias que lhes são dadas a viver (MARX, 1978).

O campo Trabalho-Educação, como área de pesquisa no Brasil, criouse no início dos anos 1980 (CALAZANS, 1995) ${ }^{10}$, como Grupo de Trabalho, "Educação e Trabalho" no âmbito da ANPEd (Associação Nacional de Pósgraduação e Pesquisa em Educação) ${ }^{11}$. Em 1988, por ocasião da $11^{a}$. Reunião Anual da Associação, levou-se adiante o "aprofundamento da temática do trabalho no interior do capitalismo hoje, a questão do trabalho como princípio educativo" (FRIGOTTO, 1988, p. 25). No ano seguinte, 1989, o GT inverteu os termos e passou a se apresentar como Grupo "Trabalho-Educação"12. Na nova denominação, o trabalho foi destacado como parte fundamental da sociedade, totalidade social onde se situa a educação como uma das mediações do mundo do trabalho e de suas contradições.

A inversão dos termos para Trabalho e Educação seguiu-se ao avanço das forças progressistas, cujos intelectuais mais ativos, como lideranças do GT, eram Gaudêncio Frigotto, Miguel Arroyo, Paolo Nosella, Acácia Kuenzer, Lucília Machado. Eram estudiosos das obras de Marx, a exemplo de $O$ Capital (MARX, 1980); da Crítica à Economia Política (MARX, 1977); dos escritos de Gramsci, introduzidos, principalmente, por Dermeval Saviani (1980) e de outros trabalhos de intelectuais brasileiros, como Octavio Ianni, Caio Prado Jr., Florestan Fernandes.

Os pesquisadores do campo se identificam pelos estudos que desenvolvem sobre o mundo do trabalho, o mercado de trabalho, as relações de trabalho, a formação profissional, técnica e tecnológica, a educação dos trabalhadores, a formação integrada entre o ensino médio e a educação profissional e

\footnotetext{
${ }^{10}$ Além do GT Trabalho e Educação da ANPEd, até 2015, existiam, no Brasil, 34 grupos de estudos e pesquisas neste campo de investigação.

${ }^{11}$ Ver o histórico de sua criação e transformação em Ciavatta (2017b).

12 O Programa de Pós-graduação em Educação da UFF, identifica uma das linhas de pesquisa, por "Trabalho-educação", reafirmando a unidade do campo de investigação sobre as relações recíprocas entre o trabalho e a educação (v. http://www.ppg-educacao.uff.br/novo/index.php/ campos-de-confluencia ).
} 
seus detalhamentos. Têm por base teórica o pensamento crítico expresso pelo materialismo histórico e seus diversos interlocutores ${ }^{13}$.

A diferença de grafia não parece ter sido sentida como significativa no interior do GT Trabalho-Educação da ANPEd. Mas, do ponto de vista epistemológico, cabe observar que o termo "Trabalho-Educação" é uma unidade, enquanto "Trabalho e Educação" são dois termos justapostos, mantendo cada um seu significado próprio. Conheço apenas um trabalho que faz uma reflexão epistemológica específica sobre a questão, Lucília Machado (2005), para quem "O uso do hífen implica a ideia de indissociabilidade e de mútua implicação" (p. 128) ${ }^{14}$.

Machado, citando Cours-Salies (1995, apud id., p. 10), lembra que o termo trabalho tem sido utilizado com diferentes sentidos: "fator de produção mensurável e intercambiável, emprego, qualquer atividade humana orientada por uma situação concreta" (ibid.). Esta é uma questão teórica e de pesquisa das políticas educacionais nas sociedades capitalistas, para a superação de uma visão do trabalho e da educação profissional restrita às necessidades do mercado de trabalho ${ }^{15}$. Compartilho da análise da autora que cita duas referências importantes à estruturação do pensamento do GT Trabalho-Educação, Gramsci e Lukács.

Lukács (1978) trouxe uma contribuição fundamental a este campo de pesquisa, ao sentido do trabalho, como vimos, quando trata das "bases ontológicas do pensamento e da atividade do homem". O trabalho "enquanto base dinâmico-estruturante de um novo tipo de ser", produto do desenvolvimento da reprodução dos seres inorgânicos, aos seres orgânicos da natureza, e destes à separação "dos seres vivos na competição biológica com seu mundo ambiente. O momento essencialmente separatório é constituído não pela fabricação de produtos, mas pelo papel da consciência" (p. 4). É o que nos faz humanos.

Segundo o autor, "O produto, diz Marx, é um resultado que no início do processo já existia ‘na representação do trabalhador', isto é, de modo ideal", no pensamento (LUKÁCS, id.). Lucília Machado (id.) também considera que a premissa fundamental do campo Trabalho-Educação "deriva de nossas

\footnotetext{
${ }^{13}$ A exemplo de Mészáros (2002 entre outros); Antunes (2000 entre outros); Saviani (1980 entre outros); Frigotto (1984 entre outros), Ciavatta,1990 entre outros). Em trabalho recente, Nogueira (2019) cita alguns grandes intelectuais interlocutores de Karl Marx (1818-1883): Max Weber (1864-1920), Gyorgy Lukács (1885-1971), Antonio Gramsci (1891-1937), Karl Korch (18961961), Henri Lefvre (1901-1991), Jean Paul Sartre (1905-1980), Norberto Bobbio (1909-2004). Adam Schaff (1913-2006), Lucien Goldman (1913-1970), Zygmunt Bauman (1925-2017), Jurgen Habermas (1929) (p.46-53).

${ }^{14}$ Outros termos em que dois nomes adquirem unidade semântica: arco-íris, tenente-coronel. tia-avó.

${ }^{15}$ V. a explicitação detalhada destas questões em Ciavatta (2009, p. 17 e ss.).
} 
leituras marxianas sobre o processo de hominização", sobre a essência do homem (p. 130) ${ }^{16}$.

Em seu artigo, Machado (id.) conclui que Trabalho-Educação tem um sentido específico: "trabalho e educação não são dois objetos de pensamento que possam ser classificados, a rigor, como elementos ou noções simples. Um já contém o outro antes mesmo de colocados em associação" (p. 129).

A educação faz parte do mundo do trabalho na medida em que participa do conhecimento gerado pelos processos de transformação da natureza e da sociedade. Cabe reconhecer a importância política da educação na vida da sociedade, e sua insuficiência conceitual como campo disciplinar para a pesquisa científica. Machado (id.) também argumenta, em seu texto, que a delimitação dos fenômenos no campo Trabalho-Educação não deve ocorrer em prejuízo das dimensões históricas da totalidade de todo fenômeno social, de suas múltiplas determinações e mediações (p. 128).

Não obstante a grande obra de Marx ser a crítica ao modo de produção capitalista, sua análise não se faz apenas pelo aspecto econômico. Sua teoria considera a economia como parte da vida social (MARX; ENGELS, 1979). Os sujeitos constroem sua história em espaços-tempos determinados. Esta é uma concepção ampliada do sentido do trabalho para a superação do viés marxista economicista e da visão anticlassista pós-moderna. Assim, "historiadores de ofício" marxistas elaboram suas análises históricas sobre mundo do trabalho, trabalhadores, formação da classe operária e questões afins, a exemplo de Hobsbawn (1987 e outros); Thompson (1987 e outros).

Diferente da história tradicional que registrou a vida humana dando protagonismo aos heróis, aos poderosos, aos grandes feitos, Marx eleva todos os atos da vida humana ao nível do acontecimento. A história é a produção social da existência (MARX; ENGELS, op. cit.). Esta é sua concepção inovadora de história, tão bem apropriada por muitos historiadores que incorporaram novas abordagens, novos temas, novos objetos, os grandes acontecimentos e os fatos do cotidiano ${ }^{17}$. como a "história a contrapelo" (BENJAMIN, 1987), "a história dos de baixo" ou "a história dos vencidos" (DECCA, 1984).

Do ponto de vista teórico-metodológico, duas questões ainda merecem atenção: a história como processo e a história como método ${ }^{18}$. É Marx quem vai explicitar os elementos políticos e ideológicos da história ao concebê-la como o processo da vida real dos homens e como a ciência desse processo, como conhecimento de uma matéria e a matéria desse conhecimento, ou ainda, a história como processo vivido, a história como objeto e como método de conhecimento (ODÁLIA, 1965; CIAVATTA, 2009). Na obra marxia-

\footnotetext{
${ }^{16}$ Citando O capital (MARX, 1980), a Ideologia alemã (MARX e ENGELS, 1979) e os Manuscritos econômico-filosóficos (MARX, 2004) (ibid.)

${ }^{17}$ Referimo-nos, especialmente, à École des Annales e seus desdobramentos (entre outros, Burke, 1991)

${ }^{18}$ Para maior detalhamento destas questões, ver Ciavatta, 2009.
} 
na, a história e a pesquisa histórica não se colocam como uma questão de etapas definidas fora de um objeto de estudo. $\mathrm{O}$ que não significa que a questão do método esteja ausente de sua obra. Até porque, no pequeno e denso texto que é o "Método da economia política" (MARX, 1977), estão expostas as principais questões teórico-metodológicas sobre as quais Marx (1980) elaborou $O$ capital.

O tratamento historicizado dos fenômenos envolve diferentes temporalidades, tanto em relação ao tema de estudo, quanto ao espaço-tempo em que ocorrem os acontecimentos tratados e aos sujeitos em foco nas pesquisas. Ter como fundamento o método da economia política e a história como produção social da existência significa considerar os objetos, fenômenos e acontecimentos na totalidade social de que fazem parte. São as mediações, isto é, os processos sociais complexos que os constituem enquanto tais, são as contradições que se apresentam pelas ações e interesses que se opõem entre os diferentes sujeitos, grupos e classes sociais.

Metodologicamente, no tratamento do tema, a historicidade deve estar presente na superação da visão geral política ou sociológica pela análise da especificidade do acontecimento histórico, irrepetível no tempo e no espaço do mundo que é exterior ao pensamento. Na narração ou na narrativa ${ }^{19}$ dos acontecimentos, deve-se tratar de sua particularidade histórica e, consequentemente, contemplar as categorias espaço-tempo, totalidade social, contexto, mediações, contradições, sujeitos sociais, fontes da pesquisa.

$\mathrm{Na}$ historiografia com base no materialismo histórico, cabe ainda ter presente a visão crítica sobre as políticas (sociais, econômicas, políticas, culturais, educacionais) que determinam o curso das relações de trabalho sobre $o$ trabalho simples e o trabalho complexo, o trabalho alienado, assalariado ou precarizado, a divisão social do trabalho e das classes sociais etc ${ }^{20}$.

O historiador Jorge Nagle (1984) aponta o "desprezo pela dimensão histórica", e as dificuldades comuns às deficiências do estágio atual dos estudos históricos no país, tais como: modismos teóricos mal assimilados e pouco criticados (quando uma abordagem mais ampla do social tomou o lugar dos estudos descritivos tradicionais); falta de continuidade na pesquisa; desprezo pelas informações, pelo dado empírico de natureza estatística, legislativa, de-

\footnotetext{
${ }^{19}$ Não obstante os diversos sentidos dados ao termo narrativa, tradicionalmente, a narrativa histórica refere-se ao modo como a realidade é representada em cada sociedade (oral, escrita, ico nográfica etc.) ou aos modos de pensar a história e de escrevê-la (TRAVERSO, 2008).

${ }^{20}$ No Brasil, particularmente, após o regressivo cancelamento da CLT (Consolidação das Leis do Trabalho) e de outros direitos complementares, das conquistas dos trabalhadores, dos anos 1940 até os dias atuais, o Decreto-Lei 5.452, de 01/05/1943, pela Lei 6.019, de 03/01/1974, pela Lei 8.036, de 11/05/1990 e a Lei 8.212, de 24/07/1991, pela atual reforma (contrarreforma) trabalhista: Lei 13.467, de 13/07/2007 (vigência em 11/11/2017) e a Medida Provisória 808 , de $14 / 11 / 2017$, a fim de adequar a legislação às novas relações de trabalho no sentido da desregulamentação e precarização dos direitos dos trabalhadores; a extinção do Ministério do Trabalho (MP 870/2019).
} 
mográfica, religiosa, artística; esquemas de interpretação simplistas e inadequados (p. 27-8).

A estes acrescento os modismos mais recentes, pós-modernos, culturalistas, desenraizados da complexidade dos contextos socioeconômicos e políticos. Para Nagle (id..), na história da educação, acumulam-se as dificuldades da historiografia mais geral e as específicas da área de educação. De outro, há que se ter em conta o momento crítico em face do avanço atual do pensamento conservadorismo, aquilo que Cueva (1987) chamou de "a direitização do Ocidente".

Nunes (1989) destacou o que considerava o tripé da renovação do tratamento histórico das questões educacionais: o debate sistemático da produção historiográfica em educação; a enunciação e o enfrentamento de certas questões teórico-metodológicas; a conservação e a produção de fontes na área de pedagogia (p. 39).

\section{Trabalho-Educação: o trabalho como princípio educativo ou o princípio educativo do trabalho? ${ }^{21}$}

O trabalho como princípio educativo ou o princípio educativo do trabalho são termos que se referem a uma mesma realidade, conceituados de dois pontos de vista diferenciados, ambos com base no materialismo histórico. Semanticamente, guardam diferenças sutis de linguagem. No primeiro caso, o foco é a educação sob a determinação do trabalho; no segundo caso, o foco é o trabalho que tem em si o atributo educativo.

Ao falar em "princípio" educativo, não faço apelo ao seu sentido clássico de princípio como "ponto de partida" ou "fundamento" de um processo qualquer, "causa" da qual parte um processo de conhecimento. Assumo o termo no sentido de racionalidade do real, cuja gênese está em Hegel, quando o pensamento se obriga a uma busca para compreender a razão no interior da própria trama do ser. "Princípios são leis ou fundamentos gerais de uma determinada racionalidade, dos quais derivam leis ou questões mais específicas" (FRIGOTTO; CIAVATTA, 2012, p. 749).

\subsection{O trabalho como princípio educativo}

Trata-se, de pensar o trabalho como princípio educativo, a partir de uma concepção ontológica do ser, o que se opõe à tradição filosófica que separa razão e realidade e entende o racional como uma norma que se impõe ao ser, para julgá-lo e opor-lhe uma regra superior (AKOUN, 1977, p. 409). Trata-se de pensar historicamente o conceito, pensar a racionalidade, a norma-

${ }^{21}$ Esta seção tem por base Ciavatta, 2009. 
tividade implícita em determinados processos sociais que tornam (ou não) o trabalho capaz de educar, de desenvolver o homem nas suas potencialidades.

No Brasil, muitos são os autores que tem desenvolvido este princípio da fundamental importância do trabalho na educação (a exemplo de FRIGOTTO, 1985; KUENZER, 1988; CIAVATTA FRANCO, 1990; SAVIANI, 1994; FRIGOTTO; CIAVATTA, id.). Nesta concepção, destaca-se a concepção gramsciana do trabalho que educa. $O$ trabalho como princípio educativo é uma expressão tida como elucidativa da importância do trabalho na educação do jovem, não apenas no seu aspecto de preparação estrita para o exercício disciplinado do trabalho. Mas, também, no acesso ao conhecimento técnico e científico dos processos produtivos e no entendimento das relações de classe subjacentes ao trabalho e à educação nas sociedades capitalistas ${ }^{22}$.

Nas suas reflexões sobre o trabalho como princípio educativo, Gramsci (1981) parte, basicamente, de duas questões: a relação educação e política e a relação educação e trabalho. Ele assume que educar é formar o homem que é um produtor e consumidor de bens materiais e espirituais, e que esta produção somente pode ocorrer em uma comunidade humana, isto é, em sociedade. O homem é um ser (animal) político segundo Aristóteles. Significa que ele não apenas produz e consome, mas também decide sobre a produção e seu uso; ele se prepara, ele se educa para a vida política, para a função de dirigente em sua sociedade.

Cabe aqui, resgatar, brevemente, a gênese histórica da expressão em Gramsci (id.), extensamente comentada por Manacorda (1981). Gramsci polemiza a reforma Gentili de 1923, na Itália, quanto aos conteúdos e quanto à es trutura do ensino humanista tradicional. Mas seu foco principal é a crítica a uma educação escolástica separada da realidade do trabalho, das transformações da sociedade, do desenvolvimento tecnológico. Na Introdução ao livro Manacorda (id.) argumenta que sua crítica é "cultural e política no sentido amplo", a uma educação de classe (p. 26). Opondo a escola oligárquica à escola ampliada para toda a população, a escola democrática, Gramsci (id.) defende que é preciso

${ }^{22}$ O legislador absorveu o mesmo princípio ao elaborar o Parecer CEB/CNE n. 05/2011: "Pelo primeiro sentido, o trabalho é princípio educativo à medida que proporciona a compreensão do processo histórico de produção científica e tecnológica, como conhecimentos desenvol vidos e apropriados socialmente para a transformação das condições naturais da vida e a ampliação das capacidades, das potencialidades e dos sentidos humanos. O trabalho, no sentido ontológico, é princípio e organiza a base unitária do Ensino Médio. Pelo segundo sentido, o traba lho é princípio educativo na medida em que coloca exigências específicas para o processo educacional, visando à participação direta dos membros da sociedade no trabalho socialmente produtivo," (p. 21). Disponível em:

$<$ http: / portal.mec.gov.br/index.php?option $=$ com docman\&view $=$ download $\&$ alias $=8016-$ pceb005-11\&Itemid=30192>. Acesso em: 19 jan. 2019. 
[...] criar um tipo único de escola preparatória (elementar-média) que leve o jovem às portas da escolha profissional, considerando-o com pessoa capaz de pensar, de estudar, de dirigir ou de controlar quem dirige (p. 150).

Manacorda (id.) expõe o pensamento de Gramsci que critica a escola tradicional e coloca-se a favor de um "novo tipo de intelectual - o técnico vinculado à produção industrial - cuja função consiste em ser sempre persuasivo, ser construtor, organizador. Sua formação vai da técnica-trabalho à técnicaciência e à concepção humanístico-histórica". Gramsci reflete sobre a relação pedagógica a partir dos valores culturais e da relação política, ele "unifica a razão historicista e a tecnológica na 'história da ciência e da técnica' como base formativa da nova escola unitária" (p. 28).

\subsection{O princípio educativo do trabalho}

$\mathrm{Na}$ expressão o princípio educativo do trabalho, destaca-se também a importância do trabalho que educa, mas seu foco específico é o trabalho na sociedade capitalista. Não se trata apenas de uma diferenciação semântica, mas da concepção do trabalho e da relação do ser humano com o trabalho ${ }^{23}$. Um dos autores dessa especificação do termo assim o explicita:

O elemento central que define a concepção do princípio educativo do trabalho funda-se na explicação marxiana de que é o trabalho que humaniza o homem, mas que no modo de produção capitalista, em que encontra-se subsumido ao capital, é fonte de alienação, que educa os trabalhadores no sentido de uma sociabilidade de relações sociais estranhadas (TITTON, 2008, p. 6).

Outros autores (PALARO; BERNARTT, 2012) tratam do "trabalho como princípio educativo e princípio da alienação" (p. 293). Apoiando-se em Tumolo (2006, apud id., p. 299), fazem uma leitura do trabalho, em Marx, como estranhamento do trabalhador diante do produto do trabalho que não lhe pertence, dadas as condições de exploração, na sociedade capitalista (id., p. 297-299).

A argumentação retoma uma discussão antiga no GT Trabalho-Educação, nos anos 1990: se o trabalho é fonte de exploração e de alienação na sociedade capitalista em que vivemos, como pode ser educativo? O encaminhamento teórico-prático dada à questão tem base em alguns argumentos.

O primeiro deles é a necessidade do exame das condições de trabalho, a partir da análise da mercadoria, nos elementos que Marx (1980) sintetiza como "o fetiche da mercadoria": a dissimulação da expropriação do produto

\footnotetext{
${ }^{23}$ Neste caso, não fiz uma pesquisa exaustiva do uso do termo. Busquei alguns autores que utilizam e argumentam sobre o sentido da expressão.
} 
do trabalho, do conhecimento produzido e da sociabilidade que se gera na produção, quando o trabalho humano assume a forma de valor, na compra e venda da força de trabalho (p. 79-93). As condições históricas de exploração e alienação do trabalho educam no sentido adverso aos interesses da classe trabalhadora, para a realização dos interesses de classe do proprietário dos meios de produção.

Mas não são todas as formas de trabalho para suprir nas necessidades básicas da sobrevivência que se situam nas relações mercantis da produção alienada. São as condições de trabalho que constituem sua totalidade social, como "síntese de múltiplas determinações" que definem o caráter educativo ou alienador do trabalho. Ele faz parte do mundo da necessidade e da liberdade teorizado por Lukács ao tratar da ontologia do ser social (1978 e outros).

Introduzo, assim, o segundo argumento crítico da análise do princípio educativo do trabalho reduzido ao trabalho alienado. O resgate da concepção dialética da realidade como totalidade social inclui o trabalho alienado na submissão às relações produtivas capitalistas; e do trabalho não alienado como produção da vida do ser humano em suas múltiplas dimensões. Esta concepção situa-se na totalidade das ações humanas, no campo da história como produção social da existência. Ontologicamente, é pelo trabalho, que o ser humano produz os meios de vida e também se educa, produz conhecimento e sociabilidade.

Terceiro, nesta visão dialética da realidade, a categoria contradição amplia a compreensão do argumento anterior. Considera o ser humano em seu permanente movimento de transformação, e o trabalho que, mesmo nas condições mais perversas de exploração, engendra a percepção da exploração e os movimentos contraditórios no sentido da libertação, como Lukács (1978) expõe a dialética da necessidade e da liberdade inerente a todo trabalho humano. Quando os autores (TITTON, 2008; PALARO; BERNARTT, 2012), identificam as ações educativas apenas com o trabalho alienado, na relação Trabalho-Educação, abrem mão da historicidade das ações humanas, da totalidade social em que elas ocorrem, da concepção dialética da história como movimento do real sob a ação dos sujeitos, e das contradições inerentes a toda e qualquer aspecto da vida humana.

Outra possibilidade de interpretação do pensamento destes autores, é o recurso a outros autores, a exemplo de Mészáros (2002; 2005 entre outros) ${ }^{24}$ que, na crítica à escolaridade formal. considera que o trabalho somente poderia educar após o fim do sistema de exploração capitalista, o que, implicitamente, requer um processo revolucionário. $\mathrm{O}$ argumento é pertinente, e esta pode ser uma perspectiva de futuro, mas, no presente, sinaliza abrir mão das

\footnotetext{
${ }^{24}$ No entanto, ressalvo a consistente análise de Mészáros sobre as relações sociais capitalistas no uso instrumental da educação e dos sistemas de ensino a serviço do capital, assim como sua concepção da "educação além do capital” (2005 e outros).
} 
ações de intervenção na concepção de educação básica e profissional nos sis temas de ensino.

Um último aspecto sobre a questão está no trabalho teórico-prático do campo Trabalho-Educação que buscou superar a visão estrita dos processos escolarizados e de preparação para o trabalho pautados pelas necessidades da produção capitalista que exige comportamentos, disciplina, qualificações, competitividade, produtividade, desregulamentação das relações de trabalho. Cabe ressaltar que os processos educativos não ocorrem apenas na escola, mas também nos espaços informais da educação para o trabalho, nas experiências de vida para a cidadania, para a cultura, nos movimentos sociais e no desenvolvimento das capacidades organizativas e de resistência.

Todo empenho teórico e prático dos pesquisadores que utilizam a base teórica do materialismo histórico, está no sentido de superar a compreensão de formação profissional apenas como treinamento para atividades manuais, e conceber a educação como formação humana, como um processo de ampliação do conhecimento e da leitura do mundo. Como o trabalho, a formação humana deve ser entendida e praticada em relação aos conceitos de totalidade da vida social e do trabalho como atividade estruturante da vida humana em todo seu potencial, dignidade e ética ${ }^{25}$.

Esse é o locus mais visível da educação pelo trabalho, seja no sentido técnico seja no sentido político, como movimento que oscila nas duas direções: tanto educação pelo trabalho na sua negatividade, enquanto submissão e expropriação do trabalho, quanto na sua positividade enquanto espaço de luta, conhecimento e transformação das mesmas condições. É nas relações imediatas do trabalho produtivo e nas relações mediatas da política que ocorrem os embates capital e trabalho e o "fazer-se trabalhador" (THOMPSON, 1987).

Historicamente, observa-se que, à medida que a escola adquire a finalidade de preparar para as exigências da produção capitalista, ela assume, também, as exigências da ordem social desenvolvida nos processos de trabalho, tais como disciplina, exatidão, submissão física, técnica e moral, cumprimento estrito dos deveres, pontualidade, contenção corporal e afetiva. Salvo os processos de resistência pedagógica e dos próprios trabalhadores, a escola tende a assumir os deveres impostos pela produção, os cursos breves para o trabalho simples, através dos mecanismos políticos e orçamentários do Estado; e relega a segundo plano, sob mil artifícios ideológicos, o direito à educação pública e de qualidade que fundamenta as demandas da sociedade civil.

Se a realidade da escola a serviço do sistema capital cultiva o trabalho na sua negatividade, ela também oferece aos jovens a oportunidade de acesso aos conhecimentos técnicos, tecnológicos, científicos e histórico-sociais presentes no exercício teórico-prático da educação profissional. A totalidade social dos processos educativos não se esgota na alienação prevista pelo sistema,

\footnotetext{
${ }^{25}$ Esta reflexão recupera a análise de Ciavatta (2012, p. 141-145) com base em Rodrigues (2001)
} 
ela gera também a resistência que pode conduzir à sua superação.

\section{Considerações finais}

Neste breve texto, sobre a pertinência do Trabalho-Educação como a história em processo que se realiza na unidade dos termos, busquei argumentar sobre sua unidade semântica com sentido ontológico, epistemológico, histórico e educacional. Neste percurso, foi importante a leitura do texto de Lucília Machado (2005) sobre a unidade do termo Trabalho-Educação. Sob meu ponto de vista, este constitui uma epistéme no sentido marxista de categoria ou conceito, com base na contradição capital e trabalho na sociedade capitalista, e na concepção da história como produção da existência dos seres humanos em todos os tempos.

Sua unidade também tem apoio na concepção dialética do trabalho como princípio educativo, que tem sentido positivo quando a educação para o trabalho se torna formação humana, com o desenvolvimento de todo potencial intelectual, físico, afetivo de produção da vida, de compreensão dos processos sociais e de resistência à exploração. Mas contempla também a formação para o trabalho no seu sentido negativo, como meio de alienação e sujeição dos trabalhadores às condições adversas em que o trabalho soe se apresentar. São as condições de trabalho expressas na totalidade dialética de sua especificidade e de suas contradições históricas que permitem compreender os aspectos de humanização e os de alienação.

Semanticamente, as expressões o trabalho como princípio educativo e o princípio educativo do trabalho se equivalem. A discussão remonta aos anos 1990, no GT Trabalho-Educação da Anped, com base em uma concepção dialética da totalidade social do trabalho e da educação, O que distingue as duas expressões é a concepção ontológica, epistemológica e histórica de seu significado.

A primeira, com base na concepção dialética da totalidade social, concebe o trabalho ontologicamente, base estruturante da vida em sua positividade, e na particularidade negativa das relações sociais de trabalho na sociedade capitalista. A segunda, reduz o trabalho e a educação à sua negatividade em decorrência da alienação histórica do trabalho na sociedade capitalista. Argumentamos em favor da interpretação dialética da totalidade social em que ocorre o trabalho em todas as suas dimensões.

Rio, fev. 2019 



\section{II \\ COMO SE ESCREVE A HISTÓRIA DA EDUCAÇÃO PROFISSIONAL - Caminhos para a historiografia*}

Maria Ciavatta

"Eu sou a caneta dourada que escreve nos tabelião.

Eu escrevo pros governo as leis da Constituição.

Escrevi nos papel de linho, pros ricaço e pros barão, $S$ ó ando nas mãos dos mestres, dos homens de posição"

(Capitão Barduíno / Teddy Vieira) ${ }^{1}$

\section{Introdução}

Este texto é parte da pesquisa que desenvolvemos sobre historiografia em Trabalho-Educação, como se escreve a história da educação profissional ${ }^{2}$. Há uma ambiguidade implícita na expressão "como se escreve a história". Tanto se refere à forma como alguém, o historiador, o literato ou outro letra do relata os acontecimentos ou escreve sobre fatos que presencia ou de que toma conhecimento, como se refere aos acontecimentos propriamente ditos, aqueles que, em sentido figurado, "a história escreve", e que aconteceram em algum tempo e lugar.

$\mathrm{Na}$ metáfora da enxada e da caneta que conversam, estão vários aspectos da história do trabalho e da educação no Brasil, de suas classes sociais e, implicitamente, da divisão do trabalho e das lutas de classes na produção e na apropriação da riqueza social. Em termos breves, além dos dois personagens principais, a enxada e a caneta, são vistos, em cena, o governo, as leis, a Constituição, os "homens de posição", as pessoas detentoras de poder no país. Eles contam uma história que, sem muito esforço, identificamos na his-

\footnotetext{
${ }^{*}$ DOI - 10.29388/978-85-53111-86-2-f.31-56

${ }^{1}$ Estes versos pertencem ao repertório da música caipira, cantados por Zico e Zeca. In: INTERCÂMBIO, Informações, Estudos e Pesquisas. Canções do povo trabalhador. [São Paulo]: IIEP, s. d. Impresso.

${ }^{2}$ Este texto é parte dos estudos de fundamentos do Projeto de Pesquisa CIAVATTA, Maria. $A$ historiografia em Trabalho e Educação e o pensamento crítico. Como se escreve a história da Educação Profissional. Projeto de Pesquisa (CNPq, 2013-2018), Niterói: Universidade Federal Fluminense, 2012. Foram objeto de estudo os autores FONSECA (1986); CUNHA, (2000), FARIA FILHO (2001), MANFREDI (2002), MORAES (2003), OLIVEIRA (2003,), LIMA (2007), SILVA (2000). Também foram objeto de estudo, ainda em elaboração: BATISTA (2015), MEDEIROS (1987), WEINSTEIN (2000) e nossos trabalhos, CIAVATTA FRANCO, (1990; 1993), CIAVATTA (2002, 2007, 2009, 2014, 2015).
} 
tória do Brasil. Referem-se às duas classes principais do povo brasileiro, os que trabalham na terra, os capatazes, os feitores, suas ferramentas ou equipamentos mecanizados; aqueles destinados à disciplina do trabalho fabril, à maquinaria, às linhas de montagem, às ilhas de produção e seus computadores; e aqueles que aprenderam a ler e a escrever, os letrados, os executivos, os donos das fazendas, das indústrias e dos bancos.

Estes personagens representam simbolicamente figuras, tanto seres humanos, como objetos. Homens e mulheres, em diferentes épocas e contextos, são sujeitos sociais que agiram para dar a conhecer os acontecimentos salvos pela memória e por documentos em determinados espaços-tempos. Para sair da visão imediata de todos esses seres e conhecê-los na sua complexidade, precisamos buscar as múltiplas mediações (CIAVATTA, 2014) que os constituem na totalidade social de que são parte constitutiva e constituinte.

Recorremos, assim, a categorias que caracterizam os seres em questão, sujeitos e objetos; recorremos a conceitos que já incorporaram interpretações sobre esses homens e mulheres no contexto dos acontecimentos que eles personificam. Chegamos assim à história. Se avançarmos a como se escreve a história sobre a educação profissional, encontraremos diferentes relatos sobre o mesmo tema ou sobre aspectos diferentes de uma mesma questão, a exemplo de Faria Filho (2001) e Oliveira (2003).

Cada um dos autores selecionados para esta pesquisa escolheu as categorias e conceitos que melhor correspondiam à sua visão de mundo e aos seus objetivos no trato com os acontecimentos. A nós, leitores de seus textos e estudiosos de seus temas, cabe compreender a história real presente nos relatos dos acontecimentos que marcam a concepção e o desenvolvimento da história da educação profissional no Brasil, e interpretar como cada autor os relata, como escreve a história. Apresentamos as seguintes seções: como "os historiadores de ofício" escrevem a história e a historiografia; em segundo lugar, a relação presente e passado presentes na memória e na história; terceiro, as categorias e conceitos, gerais e específicos; por último, história e historicidade em Trabalho-Educação e nossas considerações finais.

\section{Como escrevem a história "os historiadores de ofício" e a histo- riografia}

Não temos a pretensão de realizar uma revisão ampla do conceito de história, ou das peculiaridades da escrita da história ao longo dos séculos (na antiguidade greco-romana, na Idade Média, no período moderno e no mundo contemporâneo) a exemplo de François Cadiu et al. (2007). Mas, com Marc Bloch (2001), para o qual "A história é a ciência dos homens no tempo e tem a constante necessidade de unir o estudo dos mortos com o estudo dos vivos" (apud CADIOU et al, 2007, p. 10), partimos da compreensão de que a história 
envolve as questões da vida humana no tempo-espaço, e não apenas sua representação.

Iniciamos nossa reflexão pelos argumentos e por algumas das controvérsias da reflexão e da prática dos "historiadores de ofício". A apresentação sucinta do pensamento de alguns autores deve ser precedida de uma observação inicial presente em vários autores que tratam da escrita da história. É o reconhecimento do conhecimento acumulado por diversas gerações de historiadores que, no contexto de seu tempo, nos legaram "um patrimônio próprio da memória das sociedades, constituído por sua historiografia" na convergência da teoria e da história (MALERBA, 2006, p. 11) ${ }^{3}$.

Rogério Forastieri da Silva $(2001)^{4}$ considera "o estudo historiográfico como o estudo da história dos escritos históricos, métodos, interpretações e as respectivas controvérsias" (p. 26). Embora eles tenham se constituído como um setor autônomo de estudos no início do século XX, seus antecedentes estão entre os antigos historiadores, na medida de suas preocupações com as narrativas e visões de mundo de outros autores, antecessores ou contemporâneos.

Em seu livro sobre História, teoria e método, Marcello Mustè $(2005)^{5}$ afirma: "Contra a passagem do tempo, que priva os homens de uma parte de si mesmos, a historiografia se consagrou à defesa da lembrança”. Mas acrescenta que, no século XX, "a imagem da memória e, com ela, a imagem do passado modificaram-se profundamente". Cita os avanços do pensamento e da ciência que trouxeram novas interrogações à história que se constituiu pela razão, ao longo dos séculos. O papel do inconsciente por Freud, a análise das estruturas sociais elementares pela antropologia e a etnologia, as representações coletivas dos estudos sociológicos são influências "[...] que atravessaram diversos ambientes sociais, geográficos e ecológicos, alargaram a compreensão e a pesquisa da memória e dos fenômenos não visíveis ao olho humano [...]. E, com as novas tecnologias, tornaram-se disponíveis novos instrumentos metodológicos de pesquisa. É como se "os diversos sentidos do passado tivessem se dividido" (p. 7-8).

Para Pierre Villar (1992) ${ }^{6}$, em seu livro Pensar historicamente, trata-se de "compreender e esforçar-se por fazer compreender os fenômenos sociais na dinâmica de suas sequências" que são complexas no espaço e no tempo" (p. 21). Para ele, Marx estava preocupado "com os mecanismos de fundo das sociedades e não com as suas formas", procurando identificar a ciência social e a história, primeiro em A Ideologia Alemã em 1845, quando afirma "Não conhecemos

\footnotetext{
${ }^{3}$ Jurandir Malerba (1964), historiador brasileiro.

${ }^{4}$ Rogério Forastieri da Silva, historiador brasileiro.

${ }^{5}$ Marcello Mustè (1959), historiador e filósofo italiano.

${ }^{6}$ Pierre Vilar (1906-2003), historiador francês.
} 
mais do que uma ciência, a ciência da história". Depois, em O Capital em 1857. Marx recorria à geografia para tratar dos recursos naturais, à história da cultura, às etnias, à guerra, à história: "O econômico é submetido à crítica no sentido que revela uma condição social". Marx baseava-se em "documentos de primeira mão", em números e em textos, sempre com base na reflexão epistemológica (apud VILLAR, 1985, p. 9-13), como no reconhecido trabalho de história, O Dezoito Brumário (MARX, 1978).

Em um de seus livros, Villar (1992), estão presentes a questão conceitual, o ofício de historiador, a história, o conceito de totalidade e de história total, a reflexão epistemológica e metodológica. No livro Iniciação ao vocabulário da análise histórica, Villar (1985), desenvolve os conceitos de história, de estrutura, de conjuntura, de classes sociais, de povos, nações e estados, capitalismo e economia camponesa.

A escrita da história, coletânea de textos organizada por Jurandir Malerba (2006) teve como critério principal de seleção dos textos, a composição de "[...] um painel, o mais amplo possível, dos campos problemáticos presentes na construção de uma teoria da historiografia" [...] com "diferentes tradições nacionais e simpatias teóricas" (p. 7). Este historiador toma, como campo problemático e investigativo, "o trabalho dos historiadores como veio da pesquisa histórica concreta" e como "um patrimônio próprio da memória das sociedades, constituído por sua historiografia” (p. 11).

O autor considera que no campo da Teoria da História, o maior avanço se deu do século XVII para o século XIX, com Friedrich Hegel e, depois, com Karl Marx que não segue Hegel no campo do "Espírito", mas "na observação das contradições inerentes à vida das sociedades de classes". Fazendo uma breve apresentação de alguns historiadores, detém-se na crítica aos "determinismos da linguagem" que afeta a história e outras ciências humanas, defendendo "uma teoria que visa desvendar os artifícios da construção do texto histórico como artefato linguístico" (p. 12).

Malerba (idem) faz a crítica às teses e propostas de duas vertentes pós-modernas: a primeira é o "antirrealismo epistemológico que sustenta que o passado não pode ser objeto do conhecimento histórico ou, mais especificamente, que o passado não é e não pode ser referente das afirmações e representações históricas". Dilui-se a história em uma espécie de literatura, e o passado seria apenas um texto. "A segunda tese é do narrativismo que confere aos imperativos da linguagem e aos tropos ou figuras do discurso, inerentes ao seu estatuto linguístico, a prioridade nas narrativas históricas". Mas, a despeito da crítica ao pós-modernismo, considera um de seus efeitos positivos contribuir para derrubar alguns dogmas, "certas versões esquemáticas do marxismo e de reminiscências cientificistas insistentes". Entretanto, teria contribuído pouco para o avanço desta ciência (p. 13-14).

O autor considera o caráter autorreflexivo do conhecimento histórico, ou seja, a crítica historiográfica, o resgate de sua própria historicidade. Detém- 
se, assim, na prática da escrita historiográfica, na experiência histórica, no conhecimento histórico e na busca de uma definição de historiografia. Discute, brevemente, os conceitos de experiência histórica e de conhecimento histórico. Toma como ponto de partida Alex Callinicos (apud MALERBA, 1995) que distingue "história" "que cobre (1) a totalidade das ações humanas passadas e (2) a narrativa ${ }^{7}$ ou o relato que delas construímos hoje, ou seja, a 'historiografia ", que se distingue da filosofia da história, e abre dois campos distintos de interpretação. $\mathrm{Na}$ forma tradicional de conceber-se a história, esta seria a "experiência histórica", a história vivida pelos sujeitos, enquanto que a historiografia ocupar-se-ia "dos processos do pensamento histórico", dos meios com que se escreve e dos porquês se escreve e se reescreve a história (p. 18).

Malerba (op. cit.) considera, entretanto, que não há um entendimento comum entre os historiadores sobre "o próprio estatuto do escrito histórico: enfim, um conceito operacional da historiografia". Mas "devido a uma característica básica do conhecimento histórico que é sua própria historicidade, temos que nos haver com todas as contribuições dos que nos antecederam." [...] Essa propriedade eleva a crítica historiográfica a fundamento do conhecimento histórico" (p. 15)

Após haver repassado o pensamento de outros historiadores sobre a questão, tais como Jorn Rüsen e Paul Ricoeur, Malerba (op. cit.), conclui que o conceito de historiografia envolve tanto o produto intelectual dos historiadores, quanto as práticas culturais, produto da experiência histórica da humanidade. Portanto, a historiografia "se apresenta duplamente como objeto e como fonte histórica", uma história que implica a teoria, os conceitos, mas, com base em Reinhardt Koselleck, ${ }^{8}$ necessariamente inscritos no "campo da história social" (p. 23-24, grifo do autor).

\footnotetext{
${ }^{7}$ Tradicionalmente, a narrativa histórica refere-se ao modo como a realidade é representada em cada sociedade (oral, escrita, iconográfica etc.) ou os modos de pensar a história e de escrevê-la. Entre os problemas metodológicos debatidos pelos historiadores, Traverso (2008) refere-se "à história enquanto narração, o que indica, simultaneamente, reconstituir e interpretar o passado", evitando a polêmica entre os positivistas e os pós-modernos, de discutir se a história é apenas um ato de escrita, isto é uma construção narrativa, optando pelo vínculo com o fato "sem o qual a narração perderia seu caráter histórico" (p. 13). Sobre o uso do termo e a expressão "a volta da narrativa", há controvérsias entre os historiadores, a exemplo de "Le Goff no Prefácio à História Nova (cf. Le Goff, 1990, p. 6-7), que entende este retorno como o que teria sucedido à morte da "história-narrativa", que era entendida como o factual que se dispunha cronologicamente na forma do relato, morte esta já efetivada pela Escola dos Annales desde os anos 30, que inaugura a "história problema", concebida como a "história aberta para as outras ciências sociais, a história que não se encerra na narrativa" (Le Goff, 1990, p. 6, apud CARDOSO, 2000).

${ }^{8}$ Reinhardt Koselleck (1923-2006), filósofo e historiador alemão.
} 


\section{História e memória e a relação passado e presente}

Como o passado adquire visibilidade histórica é um tema sempre presente nos estudos sobre história e historiografia. Mustè (2005), afirma que a teoria da histografia teve sempre que defender-se do ceticismo e do relativismo "pela dupla ambição de ocupar-se do passado e tratá-lo como verdade". $\mathrm{Na}$ base do ceticismo está a concepção de verdade científica que supõe a experiência, a comprovação das afirmações. Mas, por princípio, a história se ocupa de fatos do passado que não podem ser experimentados. Outra objeção à verdade histórica é do relativismo que considera a suposta neutralidade do conhecimento científico uma condição que a história não poderia cumprir porque o trabalho do historiador está sempre condicionado pelos pressupostos políticos e ideológicos (p. 11). Hoje, este é um argumento plenamente criticado pelo reconhecimento dos valores e interesses próprios a cada sociedade, às diversas classes sociais, a todas as culturas e concepções de conhecimento, como afirmam Marx e Engels (1979), em sua inovadora concepção de história como a vida de todos nós, de todos os dias, a história como produção social da existência.

Tanto a visão cética da história quanto a relativista são contestadas por autores clássicos como Max Weber ${ }^{9}$, Benedetto Croce $^{10}$ e outros. Marcello Mustè (op. cit.) considera importante ter claro o significado e os limites da pesquisa da verdade. Como o passado se faz presente nos estudos históricos parece ser uma forma de arguir a especificidade da ciência da história.

Para Massimo Mastrogregori (2006), "Há uma relação transcendental entre o passado e o presente: o presente deve referir-se a um passado determinado, que assim adquire realidade e visibilidade." O problema em questão é o da cognoscibilidade de um passado possível: "Condições políticas, econômicas, religiosas, morais, estéticas, convergem em um determinado presente para moldar o passado visível (um passado possível que pode tornar-se real)". Trata-se de identificar "o destino dos traços visíveis do passado" através da memória e da história das condições que o determinaram (p. 75, grifo do autor).

Autores importantes como Benedetto Croce, Walter Benjamin ${ }^{11}$, consideram que "todo presente que carrega em si as condições de cognoscibilidade". Para Maurice Halbwachs ${ }^{12}$ "as memórias tornam-se possíveis devido às condições sociais do presente (les cadres sociaux de la memoire)" (apud MASTROGREGORI, op. cit., p. 75-76). A questão da cognoscibilidade se constitui como uma "relação inédita com o passado" no final do século XVIII, criando

\footnotetext{
${ }^{9}$ Max Weber (1864-1920), jurista, economista, um dos fundadores da sociologia.

${ }^{10}$ Benedetto Croce (1866-1952), filósofo, historiador e crítico literário italiano.

${ }^{11}$ Walter Benjamin (1892-1940), filósofo, crítico e sociólogo alemão.

${ }^{12}$ Maurice Halbawachs (1877-1945), filósofo e sociólogo francês, reconhecido por sua teoria da memória coletiva.
} 
espaço para questões e problemas historiográficos, para a "memória coletiva", as memórias e todos os traços visíveis do passado no presente (ibid., p. 76).

No início do século XX, Marc Bloch (2001) ${ }^{13}$ reconhece e destaca o papel da memória coletiva na evolução histórica. Seria a memória transmitida das gerações mais velhas às novas gerações que dariam aos grupos sociais a relação do presente com o passado. Não se trata de conservar o passado, mas de reencontrá-lo ou reconstruí-lo partindo do presente. Bloch propunha uma compreensão histórica do passado. Como historiador, Bloch preocupava-se com a memória jurídica da sociedade, com a memória familiar, dos grupos religiosos e das classes sociais. Reconhece com Halbwachs a importância dos estudos sobre a "memória coletiva" para a relação passado e presente (CASADEI, 2010).

Jorn Rüsen (2009) ${ }^{14}$ tem uma vasta produção em teoria da história, em defesa do caráter científico da história e de sua relação com a prática do historiador. Inicia seu ensaio com uma afirmação esclarecedora sobre a relação memória e história: "A memória torna o passado significativo, o mantém vivo e o torna uma parte essencial da orientação cultural da vida presente. [...] A história é uma forma elaborada de memória, ela vai além dos limites de uma vida individual". A memória proporciona uma perspectiva para pensar o futuro; a história "trama as peças do passado rememorado em uma unidade temporal aberta para o futuro, oferecendo às pessoas uma interpretação de mudança temporal" (p. 164).

A partir dessa concepção básica, o autor coloca em pauta a questão política da cultura, da ideia de progresso e do conceito de identidade. Destaca sua complexidade para pensar o futuro e a ideia de progresso no mundo atual, diante do "fardo pesado de experiências históricas negativas tais como o imperialismo, as guerras mundiais, o genocídio, o assassinato em massa e outros crimes contra a humanidade" (idem). O processo de construção da identidade histórica impele para o confronto entre os horrores do passado e as possibilidades do futuro. $\mathrm{O}$ autor chama a atenção para a responsabilidade das ciências humanas no tratamento da memória e da história, pelo importante "papel cultural" que memória e história desempenham na produção do conhecimento (id., p. 164-5) ${ }^{15}$.

\footnotetext{
${ }^{13}$ Marc Bloch (1866-1944), historiador francês, um dos fundadores da Écoles des Annales.

${ }^{14}$ Jorn Rüsen (1938), historiador e filosofo alemão; investiga, principalmente, teoria e metodologia da história, história da historiografia, metodologia do ensino da história.

${ }^{15}$ No seu denso ensaio, Rüsen (op. cit.) busca "lidar com o passado em nome do futuro", discutindo "memória" (I) e "história" (II), "os discursos interculturais do presente: identidade e os problemas do etnocentrismo" (III); questões conceituais e metodológicas para a comparação intercultural (IV); experiências históricas traumáticas IV); e "os novos modos de pensamento histórico com respostas a esse desafio: luto e perdão”(vi) (p. 165).
} 


\section{Categorias e $\operatorname{conceitos}^{16}$ - Geral e específico, dois conceitos re- lativos}

$\mathrm{Na}$ pesquisa histórica, categorias e conceitos são questões fundamentais para o entendimento do próprio conhecimento que se pretende produzir. Ambos os termos lidam com o visível e o invisível. Tanto os objetos e fenômenos visíveis quanto os invisíveis ou de pensamento, são seres materiais ou mentais (afetivos, emocionais, intelectuais etc.) em situação de relação com outros tantos seres.

Quando falamos em categorias ou conceitos gerais e específicos, primeiro, ambos referem-se a seres em relação, mas conceitos e categorias servem para ordená-los de modo diferenciado. Na língua portuguesa, categoria e conceito são termos utilizados quase indistintamente nos trabalhos científicos, podem até ter o mesmo significado, enquanto termos que se referem a algum atributo dos seres. Mas também podem servir a uma ordenação mais precisa desses atributos.

De preferência, no nosso entendimento, as categorias ordenam, classificam os seres (de acordo com sua etimologia, $x \alpha \tau \eta \gamma o \varrho i \alpha$ ), a exemplo de animais vertebrados e invertebrados, seres minerais, vegetais ou animais etc. Mas servem também às ciências sociais, quando falamos nas classes sociais, a exemplo de classes de alta, média ou de baixa renda, pobres e ricos; classes proprietárias e não-proprietárias dos meios de produção etc.

No caso desta pesquisa, utilizamos "como se constroem as categorias" querendo significar que os termos ordenadores da realidade precisam de conteúdo teórico, de uma concepção de realidade para serem aptos a dar uma explicação dos fenômenos, e não apenas uma ordenação dos mesmos. Mas, repetimos, muitos autores atribuem às categorias a densidade teórica própria aos conceitos. No caso dos conceitos, por sua etimologia (concepção, $\sigma \chi \varepsilon \delta i \alpha \sigma \eta)$, eles dão conteúdo teórico aos termos, às diversas denominações científicas a ex. de economia, história, filosofia, sociedade, classe, cultura, química, botânica etc.

Passando ao segundo aspecto, quais categorias são gerais e quais são específicas torna-se uma questão do universo de seres (fenômenos, objetos) aos quais se referem. Ao tratar o tema história e historiografia, para ver como os trabalhos de pesquisa sobre Trabalho-Educação "constroem as categorias", precisamos de instrumentos analíticos com densidade teórica, explicativos do que é história e historiografia, trabalho e educação e outros termos afins. Precisamos de conceitos que devem servir ao universo amplo de todos os seres que podem ser objeto da história ou da historiografia neste campo de estudos.

\footnotetext{
${ }^{16}$ Este texto não esgota a teorização necessária dos diversos filósofos e historiadores que tratam de categorias e conceitos. Ele tem por base trabalhos desenvolvidos anteriormente para o Projeto CIAVATTA, Maria. "Historiografia em trabalho e educação - Como se constroem as categorias” (CNPq, 2008-2011).
} 
Tendo em vista que nosso referencial teórico principal é a concepção marxista de mundo, de ser humano e de sociedade, vamos selecionar os conceitos gerais, com o maior nível de universalidade, e que se constituem em instrumentos hábeis para o estudo da realidade social da educação e do trabalho. Selecionamos um conjunto de termos com densidade teórica, conceitual. Mas não significa que todos estes conceitos devam estar presentes nas pesquisas, da mesma forma, depende de sua pertinência ao objeto de estudo e do recorte da realidade escolhido pelo autor da pesquisa.

No estudo da história, algumas categorias são de grande universalidade, capazes de auxiliar no estudo de todos os seres, a exemplo de tempo-espaço, sujeito, totalidade, dialética, mediação, contradição, determinação, concreto e abstrato, essência e aparência. Outras, tais como, conhecimento, contexto, crítica, cultura, estrutura, igualdade, práxis, realidade, trabalho, ser social, verdade, pensamento crítico são também categorias que consideramos gerais, mas não são de tão ampla aplicação como as primeiras. Um terceiro conjunto de categorias, mais específicas ao tema Trabalho-Educação, foram selecionadas em nossos estudos e podem ser úteis para o tratamento de aspectos particulares ao conteúdo da pesquisa (v. Anexo I).

Para melhor compreensão do significado de categorias e conceitos, um tema que podemos situar entre a filosofia da história e a história, como campos de conhecimento, recorremos ao mais importante historiador dos conceitos, Reinhardt Kosselleck ${ }^{17}$. Na conferência em que resume as questões principais de sua pesquisa sobre os conceitos, Koselleck (1992) distingue seis pontos. Inicia distinguindo palavra e conceito, afirmando que nem todas as palavras se prestam a serem tratadas como conceitos (a exemplo de ah! oh!), "porque não comportariam prima facie uma história do conceito (seriam desprovidas de sentido)".

(i) No primeiro desses pontos trata do que possa ser considerado um conceito, aquelas palavras "a respeito do qual poder-se-ia conceber uma história", porque remetem a um sentido e, simultaneamente, a um conteúdo: "São conceitos cuja formulação exige um certo nível de teorização e cujo entendimento é também reflexivo", a exemplo de Estado, revolução, história, classe. São palavras importantes, significativas (p. 135).

Dá como exemplo de como os conceitos se formam através da história, a palavra "bund" que significa "liga", mas que passou a existir ao longo dos séculos XIII a XV na forma da expressão "formar uma liga". "Após a experimentação por duas gerações sucessivas da renovação de acordos verbais em tomo de pontos específicos, podia-se, numa visão retrospectiva, constatar que

\footnotetext{
17 "Reinhart Koselleck (1923-2006) foi um dos mais importantes historiadores alemães do pósguerra, destacando-se como um dos fundadores e o principal teórico da história dos conceitos. As suas investigações, ensaios e monografias cobrem um vasto campo temático". Disponível em: $\quad<$ https: / $/$ www.google.it $/$ webhp? sourceid $=$ chrome-instant\&ion=1\&espv=2\&ie=UTF8\#q=koselleck >. Acesso em: 19 abr. 2017.
} 
se havia estabelecido uma Liga, uma união". O termo "bund" adquiriu um sentido abstrato, generalizante, indicando a totalidade das cidades envolvidas nessa união (p. 135-36) ${ }^{18}$.

(ii) O segundo ponto tratado é a "utilização/emprego dos conceitos". Koselleck defende que todo conceito envolve Fato (Faktor) e Indicador (Indikator), de modo que "Todo conceito é não apenas efetivo enquanto fenômeno linguístico; ele é também imediatamente indicativo de algo que se situa para além da língua". Na sua visão histórica dos conceitos, o autor discorda que se reduza a história ao discurso, a um fenômeno linguístico (p. 136).

(iii) No terceiro ponto, trata dos critérios seletivos quando se pensa na escrita de uma história dos conceitos. Critica os estudos descontextualizados, as análises de discursos, em que se analisam as palavras isoladas. Considera que "todo conceito se articula a um certo contexto sobre o qual também se pode atuar, tornando-o compreensível". O mesmo se pode dizer do texto/ contexto, no sentido de um parágrafo em um texto. Cita como exemplo, a busca de dados sobre uma palavra da língua francesa, em um banco de dados. O computador pode fornecer uma infinidade de dados, mas não o contexto histórico em que cada termo adquiriu densidade teórica.

(iv) O quarto ponto tratado por Koselleck (op. cit.) é: "todo conceito só pode enquanto tal ser pensado e falado/expressado uma única vez. O que significa dizer que sua formulação teórica / abstrata relaciona-se a uma situação concreta que é única" (p. 138). Diante da polêmica que a afirmação causou e das críticas de que essa concepção invalidaria "a possibilidade de uma história enquanto diacronia", o autor parte do uso de koinomia politiké em Aristóteles que dá ao termo o significado de sua época, o qual se transformou ao longo dos séculos até os dias atuais. Seu argumento principal é o tempo histórico que é único para cada fato, para cada momento ${ }^{19}$.

A situação concreta única a que o autor se refere diz respeito ao uso do termo no seu tempo histórico, com o significado próprio em cada sociedade. A análise remete ao conceito de Estado e de economia, evidenciando que o exercício do poder político está ligado ao uso do termo relativo ao poder e à

\footnotetext{
18 "Aqui o termo Bund (liga, política, confederação) ganhou em abstração e teorização, tornando-se um conceito generalizante para além das uniões e associações particulares ensejadas por cada cidade isoladamente. Constituiu-se uma nova totalidade da qual cada cidade participa. Não se trata de uma Liga de cidades, mas de cidades de uma Liga, a qual se torna uma entidade capaz de ação" (op. cit., p. 136)

19 "Ao formular o conceito de Koinonia politike tinha Aristóteles diante de si, como experiência empírica, a realidade da polis e de sua comunidade de cidadãos. Tinha, portanto, diante de si a realidade específica e concreta tanto da cidade de Atenas quanto das outras cidades-Estado da Grécia”. Em Cícero, o quadro da experiência histórica é outro, o termo aparece traduzido para o latim como societas civilis com o sentido da cidadania romana. Nos séculos II e III, no Mediterrâneo, seu sentido é de cidadãos de um mundo ampliado. O autor acrescenta o termo koinomia / economia, hoje, que passou do sentido original de economia doméstica a diversos significados, até a ciência econômica atual (KOSELLECK, id., p. 138-9).
} 
condição econômica dos cidadãos ${ }^{20}$. "A história dos conceitos mostra que novos conceitos, articulados a conteúdos, são produzidos / pensados ainda que as palavras empregadas possam ser as mesmas" (p. 140).

Trazendo para a realidade de nosso tempo, o conceito de sociedade civil em Gramsci (1978), contrapõe-se a sociedade política e complementa o conceito de Estado (grifos nossos): "As relações entre sociedade civil ('condições de vida material' ou, em regime capitalista, sistema de produção 'privada', aparelho 'privado' de hegemonia) e a sociedade política, devem ser concebidos em função da definição de Estado como 'equilíbrio entre a sociedade política e a sociedade civil' “ (p. 234). Historicamente, são conceitos que têm sido usuais nos estudos sobre Trabalho-Educação no Brasil,

Em termos análogos, para Koselleck (op.cit.), temos as novas linguagens criadas pelos jovens em cada geração. Também é o caso da "nouveau langue" criada pelo pensamento neoliberal, ideologizando as transformações nos processos produtivos, supostamente, no sentido do interesse dos trabalhadores, enquanto são evidentes os ganhos do capital ${ }^{21}$. A análise remete, ainda, ao cuidado, nos trabalhos históricos, de utilizar certos termos particulares a cada época no contexto de seu tempo ${ }^{22}$. É o caso, também, dos termos que são conceitos com fundamentação teórica diferente entre os autores. Um caso clássico são os conceitos de ser e essência, aparência, forma e matéria (ou forma e conteúdo) na metafísica de Aristóteles e na lógica dialética de $\mathrm{Hegel}^{23}$.

(v) No quinto ponto, Koselleck (oid.) destaca algumas questões básicas para a elaboração de sua história dos conceitos. A primeira é a semântica que é "imprescindível para a comunicação linguística (Sprachbandlung [o ato da fala]) e para o uso pragmático da língua, [...] para que se possa fazer política, exercer influência social, exercer poder político, fazer revolução, enfim tudo aquilo que se possa imaginar como atos sociais e históricos". A segunda questão é o fato de que "Toda sincronia contém sempre uma diacronia presente na semântica, indicando temporalidades diversas que não posso alterar", diz o autor (id., p. 141).

\footnotetext{
${ }^{20}$ Trata-se de uma argumentação longa e detalhada que não caberia nos objetivos deste texto.

${ }^{21}$ Estamos de acordo com Bourdieu e Wacquant (2000), de que produziu-se uma espécie de "nova língua", uma nowveau langue, com a função de afirmar um pensamento único sobre a crise do capital, tais como, Estado mínimo, reengenharia, reestruturação produtiva, sociedade pósindustrial, sociedade pós-classista, sociedade do conhecimento, qualidade total, empregabilidade etc., para justificar reformas no aparelho do Estado e novas relações capital/trabalho, sempre a serviço da acumulação flexível do capital (grifo nosso). Este último termo foi bastante desenvolvido por (HARVEY, 1992).

${ }^{22}$ Os trabalhadores que se mobilizavam por melhores condições de trabalho, no início do século XX, eram "agitadores"; durante a Ditadura dos anos 1960 e 1970, eram "subversivos".

${ }^{23}$ A exemplo de o ser é e o não ser não é na metafísica de Aristóteles; o ser é e não é ao mesmo tempo, constituindo uma unidade, na lógica dialética de Hegel. Ver ARISTÓTELES. Metafísica. São Paulo: Edipro, 2012; HEGEL, G. W. F. Scienza dela lógica. Roma / Bari: Laterza, 2016.
} 
A semântica tem continuidades, aspectos de longa duração, diferentes do uso pragmático da língua. Ele toma como exemplo o conceito de história (Geschichte) que é do século XVIII. Até então, o termo tinha um sentido plural, histórias, e essas continham sempre ensinamentos morais de como se comportar. No final daquele século, passa-se a usar o termo no singular, história. Aparece a crítica de que se perdera a relação sujeito/objeto. O termo passa a significar "a história ensina" que tinha subjacente "a história do Papado, da Igreja, de uma batalha, enfim, a história de alguma coisa ou de alguém (portanto histórias) ensinava a alguém o que acontecera". Para Koselleck (id.), uma "formulação conceitual altamente abstrata e teorizada, que transforma a história em seu próprio sujeito e também seu próprio objeto" (p. 142). Após considerações detalhadas sobre alguns usos do termo nos países europeus e em Hegel, acrescenta o que entendemos ser coerente com o conceito de totalidade social, tal como se concebe a história no contexto do materialismo histórico de Marx e Engels (1979):

Certamente a formulação do conceito de história é uma criação linguística genial, quando se pensa no momento histórico dessa criação no século XVIII, momento em que as condições de percepção das histórias individuais, até então percebidas isoladamente, de forma relativamente fácil, tornam-se cada vez mais difíceis. Isto porque a compreensão de fatos históricos únicos demanda o estabelecimento de relações múltiplas com outros fatos, constituindo-se num todo altamente agregado de partes, cuja inteligibilidade escapa à experiência individual particular (KOSELLECK, op. cit., p. 143, grifos nossos).

(vi) Uma última questão bastante imbricada com a anterior, diz respeito ao uso das fontes, a partir da elaboração de seu dicionário de conceitos. $\mathrm{O}$ autor estabelece três grupos de fontes. Em todas elas, o tempo tem um papel especial. O primeiro grupo são as fontes de linguagem do cotidiano que, no seu uso, são únicas por princípio, a exemplo de uma informação pessoal, ou manchetes, editoriais do dia em um jornal, ou manifestos, petições, requerimentos que, depois que passa o tempo, perdem a força; são o que ele chama de fontes primárias. Elas se articulam ao cotidiano e seu sentido é de uma única leitura.

O segundo grupo diz respeito às palavras que são as mesmas, mas com vários significados, como nos dicionários ou enciclopédias que "têm por finalidade a descrição normativa dos conteúdos, diferentes conceitos que podem mudar com as edições". Toma como exemplo, a palavra Estado (Staat, State, État, Stato), que, em princípio, significa a situação de um ser humano, a descrição de uma situação. Mas, na acepção moderna, tem o sentido de "um lugar determinado na sociedade, segundo a concepção de uma sociedade de ordens". É um termo cujo sentido varia ao longo do tempo e nos diferentes 
países ou diferentes sociedades. Seu estudo requer "a partir das estruturas repetitivas próprias da semântica, medir inovações de sentido” (id., p. 143-45).

O terceiro grupo de fontes diz respeito aos textos clássicos, um texto de Kant, uma passagem bíblica que se mantêm inalterados ao longo do tempo. Para se ter clareza sobre o que se fala, é preciso fazer a separação analítica entre a comunicação linguística (o ato da fala) e o uso pragmático da língua. Toma como exemplo da importância desta separação, "os textos de Marx e Engels que foram canonizados pelos partidos leninistas internacionais. E no momento mesmo em que foram canonizados podem estes textos alterar os fatos, ainda que a linguagem permaneça a mesma". A compreensão dos fatos é submetida a "uma acomodação da realidade" pela linguagem. O Estado promove a administração da linguagem. O autor adverte ainda que, na pesquisa de conceitos, é preciso estar atento à distinção entre a linguagem sobre experiências de vida e a linguagem política. (id., p. 145).

Não é sem razão que os Estados ditatoriais, liberais, democráticos utilizam amplamente a publicidade no intuito de gerar uma "realidade" a seu favor $^{24}$. Para nossos estudos, cabe situar os conceitos no seu tempo histórico para compreender as implicações subjacentes aos conceitos utilizados pelos autores para reconstruir os fatos no seu tempo histórico.

\section{História e historicidade em Trabalho-Educação ${ }^{25}$}

$\mathrm{Na}$ discussão sobre a historicidade da pesquisa em educação e seus desafios teórico-metodológicos, no campo Trabalho-Educação, buscamos contribuir para a história da educação no que concerne aos processos educativos em sua relação com o mundo do trabalho ${ }^{26}$.

O historiador da educação José Luís Sanfelice (2017) assinala que a história da educação sofreu mudanças que acompanharam as transformações de outras áreas do conhecimento. Ele entende a historiografia como "o produto/conhecimento gerado pelo trabalho dos historiadores" que se caracteriza pelos temas tratados e pelas fontes utilizadas. Assinala ainda as interferências externas, tais como os departamentos universitários, as condições de trabalho, as linhas de pesquisa, os grupos temáticos e as disputas de poder que interferem nas atividades dos pesquisadores (p. 35).

Como vimos em páginas anteriores, entendemos a historiografia como a produção dos historiadores as, também, como a reflexão que os historiadores fazem sobre o próprio fazer historiográfico. Embora a história da educação no Brasil seja uma área de extensa e diversificada produção acadêmi-

\footnotetext{
${ }^{24}$ No Brasil, estamos vivendo, particularmente, a partir do impeachment da Presidenta Dilma Rousseff e as eleições de 2018, a manipulação ostensiva das palavras pelas mídias sociais.

${ }^{25}$ Parte das reflexões desta seção tem por base Ciavatta (2015).

${ }^{26}$ Este tema foi, originalmente, desenvolvido em outros trabalhos, particularmente em fóruns de história da educação (entre outros, Ciavatta, 2014).
} 
ca, são mais escassos os estudos historiográficos sobre o fazer do historiador. Em trabalho anterior (CIAVATTA, 2014) registramos a observação de Maria de Lourdes Fávero (2009) que questiona o próprio trabalho do historiador em educação. Observa que a historiografia brasileira nem sempre discute "seu próprio campo de trabalho, isto é, os estudos de história, seus pressupostos e resultados". E acrescenta, "como se colocaria essa questão no âmbito da história da educação? Haveria sempre a questão de analisar e não apenas descrever o passado, em função do presente?” (SANTOS, 1986, p.5 apud FÁVERO, ibid., p.112).

É de se salientar ainda a ausência do tema trabalho e do tema educação em estudos de "historiadores de ofício". Escrevendo sobre a historiografia da classe operária, o historiador Cláudio Batalha (1998) observa que um livro "que trata dos campos da produção histórica (CARDOSO; VAINFAS, 1997) não dedica nenhum capítulo à história do trabalho ou à história operária, ao passo que a história empresarial, a história das paisagens, ou do uso do computador merecem capítulos específicos" (p. 157.). Observação semelhante fizemos a respeito da ausência da história da educação no mesmo livro (CARDOSO; VAINFAS, op. cit.) que trata, em 19 capítulos, de muitas temáticas (econômica, cultural, política, da sexualidade, das ideias etc.), mas não contempla a história da educação (CIAVATTA, 2015). Na mesma linha de reflexão, o historiador Francisco Falcon (2006) chamou a atenção para a escassez de trabalhos de história da educação entre os historiadores.

Observamos ainda que, na área Trabalho-Educação, a produção historiográfica é restrita a alguns grandes trabalhos, livros e artigos, produtos de pesquisas, teses, dissertações. Predomina nos estudos, a crítica à economia política que, sem sombra de dúvida é fundamental para análises que se ocupam do trabalho nas sociedades capitalistas. Mas observamos que há pouca frequência às fontes primárias em arquivos.

Em parte, talvez, deva-se à sensibilidade dos jovens às urgências das questões do presente que envolvem o capital e a sobre-exploração do trabalho em sociedades desiguais como a brasileira, à dívida secular do país para com a educação básica de toda a população destinada aos ensinamentos da preparação para o trabalho. Em parte, talvez, à carência de formação, de recursos e de tempo para a pesquisa documental nos arquivos históricos. Ou ainda, porque, à exceção de poucos, raros são os historiadores que se dedicam ao estudo da educação e, consequentemente, estudam o trabalho em suas diversas formas e temporalidades, mas não a relação entre o mundo do trabalho e a educação ou a escola. A história da educação profissional não parece ser, no Brasil, uma área nobre, mesmo entre historiadores da educação que, salvo importantes exceções, a exemplo dos trabalhos de Luiz Antonio Cunha, soem não se ocupar dela.

No entanto, não obstante a grande obra de Marx ser a crítica ao modo de produção capitalista, sua análise não se faz apenas pelo aspecto eco- 
nômico. Sua teoria considera a economia como parte da vida social, e a história como a produção da existência humana (MARX; ENGELS, 1979). Falam, assim, sobre a vida de homens e mulheres que não apenas trabalham. Eles comem, se reproduzem, vivem em sociedade, se relacionam, constroem laços de amizade e de colaboração ou competição, pertencem a diferentes grupos e classes sociais, têm ideologias, afetos etc. São sujeitos que constroem sua história em espaços-tempos determinados.

Assumir a história como produção social da existência, é entendê-la como processo real da vida humana e como método de pesquisa ao nível da representação pelo pensamento, pela memória e pela escrita da história. Ao considerar as mediações sociais que constituem a realidade, tanto no nível da sociedade mais ampla, quanto no contexto das instituições, empresas, escolas, busca-se superar uma visão economicista e reducionista do materialismo histórico que dava às questões econômicas a primazia explicativa dos acontecimentos.

Esta é a concepção ampliada de história no sentido de superação do viés economicista e da visão anticlassista pós-moderna. Os "historiadores de ofício" marxistas elaboraram suas análises históricas sobre o mundo do trabalho, os trabalhadores, a formação da classe operária e questões afins (a exemplo de HOBSBAWN, 1987; THOMPSON, 1987).

Diferente da história tradicional que registrou a vida humana dando protagonismo aos heróis, aos poderosos, aos grandes feitos, Marx eleva todos os atos da vida humana ao nível do acontecimento. A história é a produção social da existência. Esta é sua concepção inovadora de história, tão bem apropriada por muitos historiadores que incorporaram novas abordagens, novos temas, novos objetos, os grandes acontecimentos e os fatos do cotidiano ${ }^{27}$. Mas os historiadores não marxistas não reconhecem o singular papel de Marx nessa extraordinária inversão do registro da vida humana, que incorpora a todos, vencedores e vencidos, como a "história a contrapelo" (BENJAMIN, 1987), "a história dos de baixo" ou "a história dos vencidos" (DECCA, 1984).

Do ponto de vista teórico-metodológico, duas questões ainda merecem atenção: a história como processo e a história como método ${ }^{28}$. É Marx quem vai explicitar os elementos políticos e ideológicos da história ao concebê-la como o processo da vida real dos homens e como a ciência desse processo, como conhecimento de uma matéria e a matéria desse conhecimento, ou ainda, a história como processo vivido, a história como objeto e como método de conhecimento. Na obra marxiana, a história e a pesquisa histórica não se colocam como uma questão de etapas definidas fora de um objeto de estudo. O que não significa que a questão do método esteja ausente de sua obra. Até porque, no pequeno e denso texto que é o Método da economia política

\footnotetext{
${ }^{27}$ Referimo-nos, especialmente, à École des Annales e seus desdobramentos (entre outros, Burke, 1991)

${ }^{28}$ Para maior detalhamento destas questões, ver Ciavatta, 2009.
} 
(MARX, 1977), estão expostas as questões teórico-metodológicas sobre as quais Marx elaborou O capital (MARX, 1980).

O tratamento historicizado dos fenômenos envolve diferentes temporalidades, tanto em relação ao tema de estudo, quanto ao espaço-tempo em que ocorrem os acontecimentos tratados, e às questões teórico-metodológicas. Ter como fundamento o método da economia política significa considerar os objetos, fenômenos e acontecimentos na totalidade social de que fazem parte. Lembramos que esses não são apenas informações ou dados como na aparência fazem crer, mas são mediações históricas, isto é, processos sociais complexos que os constituem enquanto tais, assim como as contradições ou mediações contraditórias que se apresentam pelas ações e interesses dos diferentes sujeitos, grupos e classes sociais (CIAVATTA, 2009).

$\mathrm{Na}$ historiografia com base no materialismo histórico, cabe ainda ter presente a visão crítica sobre as políticas (sociais, econômicas, políticas, culturais, educacionais), o trabalho, a divisão social do trabalho e as classes sociais em presença na sociedade. Na pesquisa de fenômenos sobre a história da área Trabalho-Educação, há também as categorias específicas que aparecem nos estudos sobre o tema. São, frequentemente, adjetivadas, tais como, capital humano, dualidade estrutural, ensino médio etc. Algumas mais gerais, outras menos gerais, mais restritas e ou mais específicas a determinado contexto ou objeto, tais como: alienação, trabalho alienado, capital, capitalismo, classes sociais, desigualdade, distribuição de renda e outras.

O tratamento histórico dos acontecimentos e suas estruturas sociais pretende alcançar o pensamento crítico sobre os aspectos da realidade em estudo $^{29}$. O termo "crítico", originalmente nascido como um pensamento político de esquerda, tem se tornado um lugar comum no vocabulário ambíguo das ideologias de direita ou de "centro", como os setores conservadores preferem se apresentar. Consideramos essa última apropriação uma usurpação política do sentido do termo ${ }^{30}$. Substitui-se a essência da realidade, suas múltiplas relações pela generalidade abstrata da palavra ${ }^{31}$.

Metodologicamente, no tratamento do tema Trabalho-Educação, a historicidade deve estar presente na superação da visão geral, política ou sociológica, pela análise da especificidade do acontecimento histórico, irrepetível no tempo e no espaço do mundo exterior ao pensamento. Na narração ou na narrativa dos acontecimentos deve-se tratar de sua particularidade histórica.

Buscamos detalhar alguns procedimentos básicos de pesquisa que são instrumentais, mas não se separam dos conceitos teóricos sobre a realidade que é objeto de estudo. Sem a pretensão de esgotar todas as questões envolvidas na escrita da história e em sua análise, expomos alguns procedimentos te-

\footnotetext{
${ }^{29}$ V. maior explicitação do termo (CIAVATTA, 2015).

${ }^{30}$ V. Torres-Rivas (2009).

${ }^{31}$ V. o exemplo da população na Crítica da economia política de Marx (1977).
} 
órico-práticos sobre as seguintes questões: tempo, memória e temporalidade, espaço ou espaço-tempo, reconstrução histórica, sujeitos sociais e fontes documentais.

\subsection{Tempo, memória e temporalidade}

Queremos situar a questão do tempo não apenas em linhas gerais, mas dar maior precisão possível no uso desta categoria: "últimos 10 anos" quais as datas limite, mesmo aproximadas? A partir dos anos 1990 (até que ano?); por quase 10 anos (quando?); nas tabelas com séries históricas numéricas, a que períodos os dados se referem?

Não é uma simples formalidade a precisão documental sobre o período da pesquisa. Zemelman (1987) lembra que a importância da questão do tempo está no fato de ser este um aspecto básico na constituição do objeto de pesquisa. É, portanto, um problema das ciências em geral e da filosofia em toda a história do pensamento. Sabemos que, como em muitas outras questões, Marx não deu um tratamento teórico específico às noções de tempo e espaço, mas elas estão implícitas na sua concepção de realidade e no tratamento empírico e científico que ele dá aos assuntos de que trata. Tempo e espaço não são substâncias ou essências independentes, mas dimensões objetivas da realidade. Marx trata de um tempo da história construída por homens concretos, e da ciência da história que se constrói não como uma coleção de fatos heroicos ou curiosos, do passado, mas como uma investigação que parte dos problemas do presente para sua gênese no passado (CIAVATTA, 2009). Para Cardoso (1988),

[...] a concepção marxista de tempo e de espaço consiste em considerálos [...] formas de existência da matéria em movimento. A existência do tempo se vincularia à transição do ser ao não ser e vice-versa, ao aparecimento do que é qualitativamente novo, ao surgimento, desaparecimento e transformação das coisas e estados. O curso do tempo - nos seus aspectos de duração e de sucessão - estaria ligado, portanto, à eterna cadeia dos atos do porvir que exprimem as mudanças sucessivas dos acontecimentos quanto à sua existência, ao futuro como processo de nascimento e de desaparecimento. (p. 28-29).

A questão do tempo na pesquisa histórica envolve também uma reflexão sobre memória e temporalidade ${ }^{32}$. Na língua portuguesa, a temporalidade é a qualidade do temporal, do provisório. Do ponto de vista social, é o movimento espaço-temporal onde se pode conhecer a particularidade histórica dos acontecimentos.

${ }^{32}$ Esta reflexão teórica tem por base Ciavatta (2007). 
O que distingue o tempo da temporalidade? Entendemos que o termo tempo expresse a concepção do fenômeno presente no movimento transformador, apreendido através das categorias que indicam situações e fenômenos (a exemplo de ontem, hoje, amanhã, cedo, tarde, inverno, verão) e dos instrumentos de medição concebidos pelo ser humano (desde o relógio de sol até os relógios digitais da atualidade). É uma categoria muito geral de pensamento. Seja o tempo percebido através da transformação da natureza, seja o tempo quantificado dos relógios ${ }^{33}$.

A temporalidade é um conceito menos elaborado na pesquisa social, sinaliza começo e fim dos movimentos do tempo-espaço, a partir dos critérios que aplicamos a esses movimentos. É o tempo no seu movimento, expresso na particularidade histórica, concretizado e percebido através da atuação dos seres humanos. São as transformações sociais da vida, do trabalho e da educação que se expressam em diversas conjunturas históricas. O que se apreende, através da memória e dos documentos preservados sobre essas transformações, é o registro que a sociedade, através de determinados sujeitos sociais, fez, preservou e transmitiu às novas gerações através da linguagem oral, escrita e iconográfica.

O tema tempo, memória e temporalidades evoca duas realidades que se complementam na análise dos fenômenos sociais, conforme a concepção dos tempos múltiplos de Braudel (1982): a relação estreita entre a estrutura econômica (o tempo longo do capitalismo), as diversas conjunturas econômicas e políticas (o tempo médio dos governantes e da sociedade em cada momento histórico) ; e o tempo breve dos acontecimentos (os discursos e ações que concretizam a direção do movimento da história).

O autor denomina de tempos múltiplos o fato de que vários tempos históricos se condensam ou se superpõem em cada acontecimento. Também a memória existe com a marca de múltiplas temporalidades: a do momento em que as lembranças afloram; os conteúdos que as compõem que podem reunir pensamentos e sentimentos de vários momentos do passado; o tempo em que tais fatos ocorreram, alguns datados, marcados temporal e espacialmente, coloridos, sonoros, emocionados ou incômodos e rejeitados; outros difusos, imprecisos, nebulosos, fugidios.

\footnotetext{
${ }^{33} \mathrm{Na}$ filosofia e na história, muitos são os autores dedicados ao estudo do tempo, em diferentes concepções sobre as quais não podemos nos deter nas dimensões deste texto que tem por base as obras de Marx (1979, 1980 e outras). Em outros referenciais teóricos, citamos Henri Bergson (i990) e sua teoria do tempo como duração qualitativa; Norbert Elias (1998), para quem o tempo é um aspecto fundamental do "processo civilizador"; há o tempo dos deuses, do sagrado, dos corpos, das máquinas (ATTALI, 1985); o tempo no pensamento ocidental (GUIDO; SAHAD, 2006)
} 


\subsection{Espaço-tempo}

Situar a questão do espaço social (geográfico e/ou institucional) dos acontecimentos narrados, tais como, o Brasil, a cidade do Rio de Janeiro, a escola tal etc. implica o movimento dos sujeitos e a transformação das instituições no tempo, nas diversas temporalidades que atravessam. A exemplo da categoria tempo, esta indicação operacional não nos exime da necessidade da compreensão conceitual do espaço.

Harvey (2006) cita exemplos dos diversos contextos que podem especificar o espaço: "material”, "metafórico", "liminar", "pessoal", "social" ou "psíquico. A estes acrescenta a construção de expressões: "espaços do medo, do jogo, da cosmologia, dos sonhos, da raiva, da física das partículas, do capital, da tensão geopolítica, de esperança, da memória ou da interação ecológica” (p. 8). E opta por conceituar espaço em sua área de pesquisa ${ }^{34}$. Mesmo brevemente, dados os limites deste texto e de seus objetivos principais, é importante refletir sobre a classificação do autor em espaço absoluto, espaço relativo e espaço relacional.

"Se considerarmos o espaço como absoluto ele se torna uma "coisa em si mesma", com uma existência independente da matéria. Ele se apresenta com uma estrutura que podemos usar para classificar ou distinguir fenômenos". É o espaço de todas as formas de engenharia e de nossa individuação; é o espaço da propriedade privada, dos Estados, das unidades administrativas etc. (op. cit., p. 10).

[...] "A concepção de espaço relativo propõe que ele seja compreendido como uma relação entre objetos que existe pelo próprio fato dos objetos existirem e se relacionarem". [...]. Associa-se essa concepção à teoria da relatividade de Einstein. Seu caráter relativo refere-se às muitas geometrias existentes, "a aquilo que está sendo relativizado e por quem" (ibid.).

O espaço relacional pode ser "considerado, à maneira de Leibniz, como estando contido em objetos, no sentido de que um objeto pode ser considerado como existindo somente na medida em que contém e representa em si mesmo as relações com outros objetos". Para Harvey (ibid.) "os processos não ocorrem no espaço mas definem seu próprio quadro espacial. O conceito de espaço está embutido ou é interno ao processo. Esta formulação implica que, como no caso do espaço relativo, é impossível separar espaço e tempo". (HARVEY, 1973:13, apud op. cit., p. 12).

Harvey (id.) dá uma razão fundamental para usar a categoria espaçotempo relacional. Estudando o papel político das memórias coletivas nos processos urbanos, deu-se conta de que elas não poderiam ser enquadradas nem em um espaço absoluto, nem em função de regras de um espaço relativo (p. 14). Ocorrem sempre em situações de relação, daí o conceito de espaço relacional.

\footnotetext{
${ }^{34}$ David Harvey (nasceu em 1935) é um geógrafo britânico marxista.
} 


\subsection{A reconstrução histórica}

Para o estudo dos fenômenos históricos selecionam-se as categorias de análise mais adequadas ao tratamento do tema. A pesquisa histórica dos acontecimentos, fatos ou dados exige o trabalho com base em categorias ou conceitos. Como vimos anteriormente, entendendo-se os conceitos como categorias com densidade teórica ou científica, decorrente de outros estudos.

Nos estudos sobre Trabalho-Educação e de como se escreve a história nesta área de pesquisa, esses procedimentos podem se traduzir, por exemplo: no conhecimento das políticas públicas e locais, das desigualdades socioeconômicas, das diversidades de identidade, culturais e de diferenças educacionais; em situar a origem das desigualdades socioeconômicas, da pobreza, da violência, que não são fatos naturais, mas frutos da distribuição de renda e de serviços sociais profundamente desiguais. Geram-se diferentes classes sociais, diferentes classes de cidadãos no acesso aos benefícios gerados pela riqueza social produzida pelo trabalho e apropriada pelas classes detentoras do capital.

Hoje, principalmente, pela financeirização da economia - não é preciso ser marxista para reconhecer as causas da desigualdade, a exemplo de Thomas Piquetty (2015) - é preciso reconhecer a gênese da desigualdade. Batalha (1998), nos seus estudos sobre a história da classe operária, situa cuidadosamente a produção historiográfica na história política e social do país. Mostra como os trabalhos acadêmicos acompanham a história do movimento operário e, também, as diferentes conjunturas no quadro maior da estrutura econômica e social do país, dos problemas que emergem dos embates das forças sociais e das ações do Estado.

A reconstrução histórica dos fenômenos e acontecimentos implica ainda alguns procedimentos analíticos resumidos por Enzo Traverso (2012) ${ }^{35}$ em conceituar, contextualizar, comparar e interpretar (grifos nossos). São procedimentos que não podem ser reduzidos a palavras ou a abstrações. Nos termos do autor, (i) "para interpretar a realidade é necessário captá-la através de conceitos", de categorias densas de interpretação teórica; (ii) contextualizá-los no conjunto de relações que lhes dão forma e conteúdo, no espaço-tempo em que ocorrem; (iii) é necessário relacionar uns fatos a outros; e (iv) compará-los refinando a análise para conhecer melhor sua especificidade. E interpretá-los como resultado dos procedimentos anteriores, buscando a objetividade de sua existência exterior ao pesquisador, mas analisados segundo os valores e escolhas do pesquisador. (p. 17).

\footnotetext{
${ }^{35}$ Historiador italiano (nascido em 1957), radicado na França, autor de trabalhos sobre a guerra e a violência no mundo contemporâneo.
} 


\subsection{Sujeitos sociais}

A pesquisa história implica a explicitação dos sujeitos sociais, a exemplo de personagens nomeados, individuais ou coletivos, da juventude em geral ou dos jovens segundo as faixas de idade, escolaridade, a idade, a área geográfica, a origem étnica, a idade, relações de trabalho assalariado ou precário, incidência da pobreza, escolaridade da família e tantas outras características dos sujeitos sociais.

A compreensão da relação sujeito-objeto, segundo a interação dialética entre o sujeito que conhece e o sujeito-objeto conhecido, é fundamental para nossa concepção da construção do objeto real e do objeto teórico da his tória, assim como para o reconhecimento dos sujeitos sociais. Segundo Schaff $(1978)^{36}$, o sujeito não seria apenas um instrumento que registra passivamente o objeto, mas tem um papel ativo, "[...] submetido por outro lado a diversos condicionamentos, em particular às determinações sociais, que introduzem no conhecimento uma visão de realidade socialmente transmitida". (p. 75).

Uma questão que merece atenção é a opção ao anonimato dos sujeitos pesquisados no caso de história oral, caso eles assim o desejem. É uma opção delicada porque reconstrói-se a história em tempos-espaços determinados, com documentação identificada. Mas circunstâncias pessoais ou políticas podem exigir identificação fictícia (explicitando-se este procedimento).

Marx (1977), introduz o conceito de totalidade social das relações recíprocas entre os sujeitos individuais ou coletivos, seu ambiente social e outros acontecimentos. O sujeito dá determinados sentidos ao ato de conhecer e ao conhecimento produzido. Não se trata mais de um indivíduo isolado, mas de um sujeito social. Neste sentido, dependendo da especificidade do tema, o tratamento da questão das classes sociais torna-se fundamental.

Hobsbawn (1983) trata das classes sociais a partir da história social concebida como história global, onde:

"O conceito de classe não define um grupo isolado, mas um sistema de relações tanto verticais como horizontais. Vai daí que, além de tratar-se de uma relação de diferenças (ou semelhanças) e distância, [a relação de classe] implica também uma relação qualitativamente diferente de função social, de exploração, de domínio e de sujeição". (p. 38).

Portanto, os trabalhos sobre as classes devem incluir o restante da sociedade de que elas são parte, da mesma forma que os donos dos escravos não podem ser entendidos sem os escravos e sem os setores não-escravistas de uma sociedade. (idem).

\footnotetext{
${ }^{36}$ Adam Shaff (1913-2006), filósofo polonês marxista, dedicados a estudos filosóficos sobre história, verdade, sociedade e informática.
} 
Marcelo Badaró Mattos (2010), tratando da formação da classe trabalhadora no Brasil, traz o pensamento de E. P. Thompson, para sua análise. Lembra que "o processo de formação da classe trabalhadora só pode ser compreendido a partir das condições objetivas que opõem, nas relações sociais de produção, os produtores diretos àqueles que, detendo os meios de produção, exploram os que nada possuem" (p. 13).

\subsection{Fontes documentais}

A história exige as fontes documentais da pesquisa e supõe sua explicitação (procedimento próprio da história, mas não apenas), sejam fontes de época ou fontes primárias (documentos e fotografias, mapas, jornais, entrevistas), sejam fontes secundárias (revisão de literatura pela qual se inicia o desenvolvimento de um tema, análises feitas por outros pesquisadores), dados estatísticos (procedimento próprio da sociologia, mas não apenas) que, pela quantidade, dão a qualidade através da dimensão ou da abrangência dos fenômenos.

Petersen e Lovato (2013) fazem uma sutil distinção entre documento e fonte. São as perguntas dos historiadores que transformam os documentos em fonte histórica, embora, “em geral, 'documento' e 'fonte' são usados indistintamente para designar os materiais de pesquisa do historiador" (p. 296).

Musté (op. cit.) retoma a reelaboração de $\operatorname{Droysen}^{37}$ (1977, apud Mustè, op. cit.) da escola histórica alemã, sobre a classificação das fontes em três tipos: (i) "restos ou vestígios (Überreste)", ou seja, "a infinita multiplicidade das coisas que podem ser tratadas como fontes imediatas" e que levam ao passado"; (ii) "os monumentos (Denkmäler)", a exemplo das "inscrições, moedas, brasões de armas, obras de arte e de arquitetura, que já apresentam uma elaboração e a 'intenção' de transmitir para a posteridade os acontecimentos na forma de memória"38; (iii) "as fontes verdadeiras e próprias (Quellen) que podem ser escritas e orais e que já propõem uma imagem refletida sobre os fatos". Segundo Droysen (apud Mustè, id.), nessas fontes, "as coisas aparecem transformadas pelas relações, nexos causais, sistemas de motivação, finalidades, condições que não constavam nos originais, mas constam em uma modalidade de representação humana" (p. 17).

Petersen e Lovato (idem) também chamam a atenção sobre a mudança das fontes históricas e de sua conceituação a partir das novas questões que emergem ao longo do tempo e que interessam à pesquisa histórica, "a história

\footnotetext{
37 Johan Gustav Droysen (1808-1884), filólogo, tradutor, historiador e teórico da história, alemão. "Sua obra abriu novas perspectivas para a definição do método histórico e para a autonomia da história ao lado das demais ciências humanas, ao conferir-lhe um estatuto rigoroso e suficiente que, em se tratando das exigências de fundamentação epistemológica, nada deixava a dever às ciências da natureza”. BENTIVOGLIO (2009, p. 7).

${ }^{38}$ Fala do poder presente em todos os monumentos e também nos documentos, na sua intencionalidade e permanência, de acordo com o pensamento inaugural de Le Goff (1992).
} 
das mulheres, dos escravos, dos trabalhadores, dos operários, da sexualidade, do amor, da loucura" (p. 297). Observam que:

(i) na atualidade houve uma ampliação das fontes para além dos documentos escritos e oficiais, tais como "o produto das ações humanas, seja na esfera do trabalho ou da família, no âmbito da religião ou do lazer", além de outros espaços de pesquisa, como os informes governamentais, as fontes arqueológicas, "os arquivos paroquiais, judiciais, de associações esportivas e recreativas, de sindicatos, hospitais, assim como de arquivos pessoais" (p. 29495);

(ii) no "resgate do contexto do surgimento do documento e a análise de sua trajetória até o presente; tão importante é saber se o material é autênti$\mathrm{co}$, como ter conhecimento de quem o produziu, em que local, sob que circunstâncias, submetido a que pressões" (p. 297-98);

(iii) os novos meios de divulgação e as novas técnicas de coleta e de acesso (os acervos em microfilme, os digitais, pelas mídias, pelos programas de armazenamento (p. 308);

(iv) a crítica externa "que investiga a origem dos documentos: por meio da menção de fatos e locais e das especificações linguísticas do texto, busca determinar sua data, seu local e autor" (p. 306);

(v) a crítica interna pela verificação da autenticidade e da veracidade do documento capaz de apreender o conteúdo e o sentido do texto, levando em conta as diferenças linguísticas e culturais (p. 306) e "o grupo social responsável por sua elaboração" (CARDOSO, 1986, p. 50-51), o que dá o sentido da produção social ou do coletivo representado no documento.

Segundo Mustè (2005), "sem um interesse atual, sem uma pergunta que tenha raízes no presente, as fontes não existiriam: os infinitos entes que elas contêm, como um segredo, um obscuro e problemático retorno ao passado, continuariam a permanecer mudas diante da necessidade de verdade dos seres humanos". É o que o autor chama de "interesse histórico", que nos instiga, nos impele a fazer perguntas, "a interrogar o passado". E acrescenta: "Organizar o passado em função do presente: esta poderia se definir como a função da história" (p. 15).

\section{Considerações finais}

Além do trabalho de pesquisa científica sobre o tema Trabalho-Educação, este texto tem o sentido de servir metodologicamente aos participantes desta investigação e a outros estudiosos do tema focalizado. Tratamos da importância de superar abordagens genéricas da crítica à sociedade capitalista, concretizando os problemas do capitalismo na sua historicidade. Esta é uma categoria fundamental na construção de toda historiografia. Ela se revela pela abordagem dos fenômenos singulares a partir de seu pertencimento a uma totalidade social e de sua localização no tempo e no espaço, sob a ação dos su- 
jeitos sociais. Na prática da escrita, significa deter-se no objeto de estudo situado no conjunto de aspectos a eles relacionados, os seus determinantes históricos.

Os "historiadores de ofício" e outros pesquisadores consultados discutem a cientificidade da história que é diferente das ciências experimentais, assim como as condições de cognoscibilidade do presente em relação ao passado. Como os próprios historiadores da educação admitem, há necessidade de que os historiadores reflitam sobre seu próprio fazer histográfico. Além de contemplar a produção histórica, este seria um sentido do termo historiografia, refletir sobre a produção teórica dos historiadores em seus trabalhos.

Detivemo-nos também, na relação presente e passado, presentes na memória e na história. Há que se fazer a crítica ao ceticismo e ao relativismo, às vertentes pós-modernas, como o "antirrealismo epistemológico" que sustenta que o passado não pode ser objeto do conhecimento histórico; e a crítica ao "narrativismo" que confere aos imperativos da linguagem e às figuras do discurso, inerentes ao seu estatuto linguístico, a prioridade nas narrativas históricas.

Metodologicamente, categorias e conceitos são termos utilizados quase indistintamente nos trabalhos científicos, podem até ter o mesmo significado, enquanto termos que se referem a algum atributo dos seres. Mas também podem servir a uma ordenação mais precisa desses atributos na elaboração do conhecimento. Mas categorias e conceitos, em nosso entendimento, devem ter a densidade teórica de uma concepção de realidade para servirem ao trabalho científico, à reconstrução histórica.

Buscamos detalhar alguns procedimentos básicos de pesquisa que são instrumentais, mas não se separam dos conceitos teóricos sobre a realidade que é objeto de estudo. Sem a pretensão de esgotar todas as questões envolvidas na escrita da história e em sua análise, expusemos alguns procedimentos teórico-práticos sobre as seguintes questões: tempo, memória e temporalidade, espaço-tempo, reconstrução histórica, sujeitos sociais e fontes documentais.

Observamos ainda que são escassos os trabalhos de história da educação sobre Trabalho-Educação. Reiteramos ainda, como fizemos em outros trabalhos, a importância da crítica à economia política levada adiante por Marx. Mas, raramente, é reconhecida sua contribuição por ter ampliado o objeto da história, pela historicidade presente em toda sua obra. A concepção de história, antes restrita ao factual e à história política dos poderosos ganha a mais fecunda transformação. Ao considerar a história como produção da existência, Marx, eleva todos os atos da vida humana a acontecimentos históricos.

Ao longo do texto buscamos expressar o que significa o pensamento crítico, que tem uma tradição no pensamento de esquerda latino-americano. Consideramos seu estatuto teórico em construção, no sentido da transformação da sociedade para um mundo com vida digna para todos, da superação da 
divisão social entre "a enxada e a caneta", da integração técnica e social entre o trabalho manual e o intelectual.

Roma / Rio, 2017-2018.

\section{Anexo I - CATEGORIAS GERAIS E ESPECÍFICAS}

Projeto "Historiografia em Trabalho e Educação e o Pensamento Crítico - Como se escreve a história da Educação Profissional" (Proc. CNPq n. 306286/2012-2)

\begin{tabular}{|c|c|c|c|}
\hline \multicolumn{2}{|c|}{$\begin{array}{c}\text { CATEGORIAS GERAIS } \\
\text { da pesquisa social }\end{array}$} & \multicolumn{2}{|c|}{$\begin{array}{c}\text { CATEGORIAS ESPECÍFICAS } \\
\text { de Trabalho-Educação }\end{array}$} \\
\hline ABSOLUTO & MEMÓRIA & Carga horária & $\begin{array}{l}\text { Mercado de } \\
\text { trabalho }\end{array}$ \\
\hline ABSTRATO & $\begin{array}{l}\text { MÉTODO CIENTÍFI- } \\
\text { CO }\end{array}$ & Certificado & Mercadoria \\
\hline ALTERNATIVA & OBJETIVIDADE & Certificação & Método \\
\hline AMBIGUIDADE & OBSERVAÇÃO & Clientes & $\begin{array}{l}\text { Modo de } \\
\text { produção }\end{array}$ \\
\hline APARENCIA & ONTOLOGIA / & Colaboração & Parceria, \\
\hline CATEGORIA & PRÁTICA & Colaboradores & $\begin{array}{l}\text { Pedagogia das } \\
\text { competências }\end{array}$ \\
\hline CIÊNCIA & PRÁXIS & Competência & Planejamento \\
\hline COMPLEXO & PROBLEMA & Competitividade & $\begin{array}{l}\text { Polarização de } \\
\text { competências }\end{array}$ \\
\hline CONCEITO & REALIDADE & Conselho de classe & Política \\
\hline CONHECIMENTO & PRODUÇÃO & Conselho & Proeja \\
\hline CONCRETO & $\begin{array}{l}\text { REFLEXO / REFLE- } \\
\text { XIVIDADE }\end{array}$ & Consumo & Professor \\
\hline CONTEXTO & REPRODUÇÃO & Currículo & $\begin{array}{c}\text { Projeto po- } \\
\text { lítico-pedagógi- } \\
\text { co }\end{array}$ \\
\hline CONTEÚDO & SABER & Controle & Projeto \\
\hline CONTRADIÇÃO & SER & Curso & Projovem \\
\hline CRÍTICA & SER SOCIAL & Disciplina & $\begin{array}{l}\text { Qualidades } \\
\text { pessoais }\end{array}$ \\
\hline CULTURA & SUBJETIVIDADE & $\begin{array}{l}\text { Educação de jovens e } \\
\text { adultos }\end{array}$ & Qualificação \\
\hline DETERMINAÇÃO & SUPERESTRUTURA & Empreendedorismo & $\begin{array}{c}\text { Reestruturação } \\
\text { produtiva }\end{array}$ \\
\hline DIALÉTICA & TELEOLOGIA & Empregabilidade, & Reforma \\
\hline EMANCIPAÇÃO & TEMPO & Empresa & Reprodução \\
\hline ESPAÇO & TOTALIDADE & Ensino médio & Reprovação \\
\hline ESPAÇO-TEMPO & TRABALHO & Ensino modular & $\begin{array}{l}\text { Reserva de } \\
\text { mercado }\end{array}$ \\
\hline ESSÊNCIA & UNIVERSAL & Ensino técnico & $\begin{array}{c}\text { Reunião } \\
\text { pedagógica }\end{array}$ \\
\hline
\end{tabular}

Continua 
Conclusão

\begin{tabular}{|c|c|c|c|}
\hline \multicolumn{2}{|c|}{$\begin{array}{l}\text { CATEGORIAS GERAIS } \\
\text { da pesquisa social }\end{array}$} & \multicolumn{2}{|c|}{$\begin{array}{l}\text { CATEGORIAS ESPECÍFICAS } \\
\text { de Trabalho-Educação }\end{array}$} \\
\hline ÉTICA & VERDADE & Equipe. & Rotina \\
\hline ESTRUTURA & TEORIA & Escola "única" & Sociedade civil \\
\hline EXPERIÊNCIA & & Escola do trabalho & $\begin{array}{l}\text { Sociedade } \\
\text { econômica }\end{array}$ \\
\hline EXPLICAÇÃO & & Escola unitária & $\begin{array}{l}\text { Sociedade } \\
\text { política }\end{array}$ \\
\hline FILOSOFIA & & Evasão & Taylorismo \\
\hline HEGEMONIA & & Ensino industrial & $\begin{array}{l}\text { Taylorismo-for- } \\
\text { dismo }\end{array}$ \\
\hline HIPÓTESE & & Exclusão & Tecnologia \\
\hline HISTÓRIA & & Formação integrada & Terceirização \\
\hline HISTORICISMO & & Formação integral & Toyotismo \\
\hline HISTORIOGRAFIA & & Gestão democrática & $\begin{array}{l}\text { Trabalho } \\
\text { abstrato }\end{array}$ \\
\hline IDEALISMO & & Gestor & $\begin{array}{l}\text { Trabalho } \\
\text { alienado, }\end{array}$ \\
\hline IDENTIDADE & & Grade curricular & $\begin{array}{l}\text { Trabalho como } \\
\text { princípio educa- } \\
\text { tivo }\end{array}$ \\
\hline IDEOLOGIA & & Grêmio estudantil & $\begin{array}{l}\text { Trabalho } \\
\text { concreto }\end{array}$ \\
\hline $\begin{array}{l}\text { IGUALDADE / DE- } \\
\text { SIGUALDADE }\end{array}$ & & Inclusão-excludente & $\begin{array}{l}\text { Trabalho } \\
\text { escravo }\end{array}$ \\
\hline INDIVÍDUO & & Inovação tecnológica & $\begin{array}{l}\text { Trabalho } \\
\text { intelectual }\end{array}$ \\
\hline INFRAESTRUTURA & & Inovação & $\begin{array}{c}\text { Trabalho } \\
\text { manual }\end{array}$ \\
\hline FORMA & & Integração & $\begin{array}{c}\text { Trabalho } \\
\text { necessário }\end{array}$ \\
\hline INTERPRETAÇÃO & & Internacionalização & $\begin{array}{l}\text { Trabalho-edu- } \\
\text { cação }\end{array}$ \\
\hline JUÍZO & & Flexibilidade, & Tutoria \\
\hline MATERIAL & & Laboratório & Utopia. \\
\hline MATERIALISMO & & Meio ambiente & \\
\hline MEDIAÇÃO & & Mercado & \\
\hline
\end{tabular}

Niterói, UFF, 2011-2017. Agradeço aos bolsistas e aos meus orientandos do PPG-Educação / UFF a colaboração no levantamento das categorias / conceitos em livros, teses e artigos da área de pesquisa em trabalho-educação. A Sânia Nayara Ferreira agradeço a organização final do conjunto. 


\title{
III \\ HISTÓRIA DA EDUCAÇÃO E DO TRABALHO NO \\ BRASIL - O livro de Celso Suckow da Fonseca ${ }^{{ }_{1}}$
}

\author{
Sandra Morais \\ Sânia Nayara Ferreira
}

\section{Introdução}

Apresentaremos neste capítulo uma análise do livro de Celso Suckow da Fonseca História do Ensino Industrial no Brasil (1986, V.1). O conjunto da obra abrange as iniciativas de educação desde a época da chegada dos portugueses, passando pelas corporações de ofícios, as ações do Governo Imperial e chegando até as providências iniciais da República. Seu livro é rico em detalhes, sendo apresentado de uma maneira metódica e historicamente linear.

Fonseca faz uma historiografia do ensino industrial no Brasil, principalmente no campo da formação profissional. Sua compreensão valiosa e sua metodologia em organizar os acontecimentos, distinguindo-os em tempos e espaços diferentes, nos permite entender a organização e evolução da educação profissional, retomando a sua gênese a partir de fontes primárias e secundárias que, se não fosse a sua dedicação à documentação e à pesquisa, nós não teríamos acesso ao conhecimento de parte substantiva da história da educação no Brasil.

No capítulo, no primeiro momento apresentamos o autor, o tema e a obra. Em seguida descrevemos as fontes primárias e secundárias que Fonseca utiliza. Sua obra abrange um extenso período da história do ensino industrial no Brasil. No terceiro momento analisamos parte da reconstrução histórica do ensino industrial no Brasil, Finalizamos analisando como Fonseca escreve a história da educação profissional a partir das categorias contradição, classes sociais e ensino industrial. Por último, nossas considerações finais.

\section{O autor, o tema e a obra}

Celso Suckow da Fonseca é uma referência fundamental para estudarmos a História do Ensino Industrial no Brasil. Nasceu em 20 de julho de 1905, na cidade do Rio de Janeiro e faleceu em 1966. Formou-se dentro de um universo técnico e literário. Concluiu o Curso de Engenharia em 1927, na

\footnotetext{
*DOI - 10.29388/978-85-53111-86-2-f.57-78

${ }^{1}$ FONSECA, Celso Suckow da. História do Ensino Industrial no Brasil. Rio de Janeiro: SENAI/ DN/DPEA, $1^{\circ}$. vol., 1986. Este artigo é parte da pesquisa desenvolvida no Projeto CIAVATTA, (2012).
} 
antiga Escola Politécnica do Rio de Janeiro. Sua carreira de engenheiro juntouse à de educador e historiador do ensino profissional e técnico do Brasil e foi diretor da mais importante Escola Técnica de sua época. Trabalhou como engenheiro da Estrada de Ferro Central do Brasil (EFCB) por trinta e cinco anos, exercendo a chefia de vários departamentos, inclusive a de "Ensino e Seleção, no exercício do qual organizou, instalou e pôs em funcionamento dez escolas profissionais" (CIAVATTA; GONTIJO, 2002, p. 253).

Não podemos vê-lo isolado das questões de seu tempo, pois participou dos êxitos e do autoritarismo no período do governo de Getúlio Vargas, "da ideologia do progresso e da ordem que teriam na organização do trabalho e da educação as bases para a formação da nacionalidade" (CIAVATTA; SILVEIRA, 2010, p. 12).

Era conservador e contra as ideias socialistas e comunistas. No entanto, era humanista e reconhecia o trabalho manual como um valor e defendia, que todos deveriam ter acesso ao conhecimento intelectual. Consolidou sua memória na história da educação brasileira por meio de sua obra maior, História do Ensino Industrial no Brasil (FONSECA, 1961; a 2a . edição é de 1986). Fonseca tinha a preocupação de pesquisar as importantes e extensas documentações disponíveis sobre o ensino industrial no Brasil.

É notória a sua expressiva atuação na criação do sistema de escolas técnicas federais. Sua trajetória na Escola Técnica Nacional, que foi construída no lugar da Escola Normal de Artes e Ofícios Wesceslau Braz, coincide com o início das atividades da própria escola, em 1942. A Escola Técnica Nacional foi implementada após a Reforma do Ministro Gustavo Capanema que colocou em execução a Lei Orgânica do Ensino Industrial em 1942. Na primeira gestão, Fonseca, buscou unir a escola ao mundo de produção. A Escola reabriu em novas instalações com o nome de Escola Técnica Federal. "O cenário era o de construção de um projeto de nacionalidade, no qual o Estado Novo assumia o processo de industrialização do país, e a entrada do Brasil no mundo capitalista de produção estava a exigir a formação de homens para a indústria nacional" (CIAVATTA; SILVEIRA, 2010, p. 22).

Fonseca faz parte de uma geração de engenheiros e educadores, dentre os quais se destacam: Francisco Montojos, João Lüderitz, Ítalo Bologna e Roberto Mange. Eles compatibilizaram suas atividades nas principais ferrovias brasileiras, mais tarde unidas na Rede Ferroviária Federal Sociedade Anônima (RFFSA), no Centro Ferroviário de Ensino e Seleção Profissional (CFESP), no Instituto de Organização Racional do Trabalho (Idort) e nas escolas técnicas-profissionais (CIAVATTA; SILVEIRA, 2010).

É importante destacarmos que esse grupo de engenheiros acreditava ser prioritário, do ponto de vista econômico e educacional, a preparação de mão de obra qualificada para a indústria e desenvolvimento do Brasil. No entanto, 
[...] do ponto de vista político, não obstante o interesse das suas iniciativas para os fins a que se destinavam - a necessária preparação de mão-de-obra, a sua política passou ao largo das necessidades educativas da grande massa de trabalhadores analfabetos, do baixo nível de escolaridade da população e das suas condições de vida e de trabalho (CIAVATTA; GONTIJO, 2002, p. 254).

Estudar e pesquisar a obra de Fonseca permite-nos entender os meandros do ensino de ofícios manuais, técnicos e industriais no Brasil. A obra mais divulgada e reconhecida é seu pioneiro trabalho sobre a história do ensino industrial, da Colônia até os anos de 1960. Sua obra ganha relevância em um país desigual, de escasso cultivo da memória e onde o ensino da preparação para o trabalho manual é um tema menor da educação.

Fonseca foi contemporâneo dos êxitos e do autoritarismo do governo Vargas, da ideologia do progresso e da ordem que teriam na organização do trabalho e da educação as bases para a formação da nacionalidade.

\section{As fontes}

Ao narrar a História do Ensino Industrial no Brasil, Fonseca preocupou-se com a heurística ${ }^{2}$ e com a autenticidade de suas fontes. $\mathrm{O}$ autor pesquisou por dez anos nos arquivos, realizando o levantamento de um extenso acervo que depois de ordenados e comentados, constitui-se na obra em análise.

As fontes de documentação foram localizadas nos acervos da Biblioteca Nacional, a ex-Biblioteca Municipal, no Arquivo Nacional, na Biblioteca da Câmara dos Deputados e na extinta Câmara dos Vereadores do ex-Distrito Federal, assim como nos acervos de muitos Estados e Ministérios (FONSECA, 1986). O autor cita na íntegra algumas leis, decretos, regulamentos, regimentos ou instruções,

[...] com o intuito de dar ao leitor não somente uma visão integral do espírito que na época respectiva presidia ao desenvolvimento do ensino de ofícios, como, também, permitir a consulta a documentos de difícil obtenção, alguns podendo, mesmo, ser considerados raros (ibid., p. 8).

A leitura de bibliografia, obras de referência e os relatórios encontrados durante o período da pesquisa documental, propiciou análises mais precisas e argumentativas, que "correspondem rigorosamente à realidade dos acon-

\footnotetext{
2 “Atividade que consiste em localizar, reunir e classificar fontes históricas, delas fazendo em se guida listas, repertórios, inventários, índices remissivos, e mesmo tratando de publicá-las, quando forem documentos manuscritos considerados de grande importância" (CARDOSO, 1986, p. 47).
} 
tecimentos que se processaram no tempo e no espaço" (ibid., p. 7), ou seja, o autor utilizou fontes primárias e secundárias.

Fonseca utiliza-se também de fontes orais por meio de entrevistas. Não podemos deixar de ressaltar que a História Oral não era problematizada na época de Fonseca. Segundo Queiroz, a História Oral é um termo amplo

[...] que recobre uma quantidade de relatos a respeito de fatos não registrados por outro tipo de documentação, ou cuja documentação se quer completar. Colhida por meio de entrevistas de variada forma, ela registra a experiência de um só indivíduo ou de diversos indivíduos de uma mesma coletividade. Neste último caso, busca-se uma convergência de relatos sobre um mesmo acontecimento ou sobre um período de tempo (QUEIROZ, 1987, p. 19).

Fonseca entrevistou professores e dirigentes, conhecedores de alguns aspectos históricos dos problemas, que constituíram-se como fonte de dados. $\mathrm{O}$ autor não especifica que tipo de entrevistas utilizou para a produção de sua obra, mas essas entrevistas foram importantes para relacionar e contextualizar os dados de sua pesquisa.

Teve o "apoio"3 e entendimentos com Secretarias de Educação estaduais e autoridades educacionais, civis e militares. Teve necessidade de ir a campo para a obtenção, in loco, de algumas informações de difícil acesso e também para uma impressão visual das condições em que se encontravam as escolas.

O uso de iconografia ganha destaque em algumas páginas de sua obra. Aparecem assim, ao longo do livro, desenhos e imagens do Padre Antônio Vieira, Manuel de Araújo Porto Alegre, Nilo Peçanha, João Luderitz, Fidélis Reis e Francisco Montojos. Utiliza a Gravura do Engenho de Cana de Açúcar da época, onde acontecia a aprendizagem de ofícios e o desenho da Nau São Sebastião em construção no Arsenal de Marinha do Rio de Janeiro de 1764. Reproduz também a pintura de Debret do Rei D. João VI e o Esquema do projeto de Horácio da Silveira para a criação de um Conselho Nacional do Ensino Profissional. Essas fontes, em alguns momentos, servem de suporte e mediação para que o leitor tenha mais contato visual e aproximação com o período tratado pelo autor. São fontes "que exigem uma série de métodos e técnicas específicos, que devem ser conhecidos por aquele que quiser trabalhar com estes materiais" (PETERSEN, 2013, p. 304).

Fonseca utiliza um número considerável de fontes iconográficas, como as mencionadas acima. Mas para nossa maior compreensão e, também,

\footnotetext{
${ }^{3}$ Consideramos que o apoio das Secretarias de Educação Estaduais e de autoridades Educacionais, constituíram-se em apoios parciais, obtidas com dificuldades, na medida em que foram enviadas "dezenas de cartas pedindo esclarecimentos, ou insistindo na sua remessa" (FONSECA, 1986, p. 8).
} 
a partir do nosso ponto de vista, nos deteremos sobre algumas que representam figuras importantes para o conhecimento da obra.

A imagem do Padre Antônio Vieira (ibid., p.17), por exemplo, ganha destaque. E abaixo da imagem, complementa com a seguinte frase,

[...] o grande pregador que, também edificou igrejas com os índios, ensinando-lhes, entre outras, a profissão de pedreiro: sendo nós mestres e os obreiros daquela arquitetura com o cordel, com o prumo, com a enxada e com a serra e outros instrumentos na mão [...]. (ibid., p. 17).

A imagem do Presidente da República Nilo Peçanha (ibid., p. 175) nos mostra a imagem física do homem que fundou o ensino profissional no Brasil, com a implantação do Decreto 7.566, de 23 de setembro de 1909, criando, nas capitais dos Estados, escolas de aprendizes artífices. Este Decreto representa um marco relevante das atividades do governo federal no campo do ensino de ofícios no Brasil.

A fotografia, como documento, "tal qual um monumento, ela mostra a realidade de um tempo e esconde, atrás de si, outros tempos que já não podemos ver senão pela sua aparência, pelos vestígios, pela reapresentação objetiva/subjetiva da realidade" (CIAVATTA, 2009, p. 114).

Fonseca reproduz também uma gravura do pintor Rugendas, de um Engenho de Cana de Açúcar, "da época, onde se processava uma rudimentar aprendizagem de ofícios” (FONSECA, 1986, p. 77). É uma iconografia importante, pois nos possibilita refletir sobre o passado e o presente, como uma "recriação da realidade, como simulacro que é e não é, ao mesmo tempo, o objeto real, a fotografia no que mostra e no que dissimula, como conhecimento dissociado da experiência que redefine a própria realidade" (CIAVATTA, 2009 , p. 115).

Destaca o desenho de Armando Pacheco, reproduzido da obra "O Arsenal de Marinha do Rio de Janeiro na História”, de Juvenal Greenhalgh. Neste desenho aparece A Nau São Sebastião, "em construção no Arsenal de Marinha do Rio de Janeiro, em 1764. Aí houve intensa aprendizagem dos ofícios ligados à construção naval" (FONSECA, 1986, p. 87).

Exibe da mesma forma, a pintura de Debret, do Rei D. João VI, "fundador de instituições, desempenhou papel de relevo na história do ensino industrial no Brasil" (ibid., p. 103). Fonseca a utiliza, talvez para ampliar a "capacidade humana de se representar, construindo a história e conferindo significado a essas representações" (CIAVATTA, 2009, p. 114).

Outro tipo de fonte utilizada está no final do $1^{\circ}$. Volume de seu livro sobre a História do Ensino Industrial no Brasil, a reprodução de um "Esquema para formação da rede de ensino técnico e profissional" de autoria de Horácio da Silveira (ibid., p. 237), "um plano de organização e difusão do ensino profissional" e de criação de um órgão "que poderia ser chamado Conselho 
Nacional do Ensino Profissional” (ibid., p. 235). Sua concepção vai influenciar a criação do SENAI (Serviço Nacional de Aprendizagem Industrial) e a implantação da Lei Orgânica do Ensino Industrial no governo Vargas.

Portanto, o uso das fontes para Fonseca é muito importante, uma vez que, antes dele, não havia livro semelhante abrangendo a história do ensino industrial no Brasil, desde o tempo do descobrimento até meados do século XX. São qualidades de Fonseca a historicidade do livro ao localizar os acervos documentais, ler, selecionar, manter uma organização de coleta de informações, para que correspondesse de forma fidedigna à realidade dos acontecimentos, situando-os no tempo e no espaço em que os mesmos aconteceram. Não podemos, no entanto, esquecer que o autor faz parte de um grupo de estudiosos que faziam uma História do Brasil factual, baseada em uma concepção positivista onde se pretende apresentar "a explicação causal dos fenômenos, de forma objetiva, neutra, livre de julgamentos de valor ou ideologias" (LOWY, 1987, p. 17).

\section{Fonseca e a reconstrução histórica do ensino industrial no Bra- sil.}

O livro de Celso Suckow da Fonseca (1986) sobre a história do ensino industrial em nosso país é narrado de maneira metódica, linear ${ }^{4}$, descritiva e de acordo com a extensa documentação existente. Sua obra é uma importante "radiografia" do ensino e aprendizagem de ofícios manuais, técnicos e industriais no Brasil e, na segunda edição (1986), está dividido em cinco volumes:

[...] o primeiro volume cobre das iniciativas de educação na época do descobrimento, passando pelas ações do Governo Imperial, até as providências iniciais da República; o segundo discorre sobre as consequências da Lei Orgânica do Ensino Industrial, do papel das Organizações Militares e sobre a ação das estradas de ferro; o seguinte aborda a criação do SENAI, o trabalho da CBAI, a preparação dos professores e a evolução do pensamento do ensino industrial. Os dois últimos volumes estão dedicados às iniciativas tomadas sobre o ensino industrial no âmbito das Unidades Federativas (FONTES, in FONSECA, op. cit., p. 56).

Segundo Fonseca, em 1500 quando os colonizadores chegaram às terras de Santa Cruz, denominação anterior do Brasil, ocuparam vários pontos da extensa costa e dispersaram-se. Em volta dos pontos de fixação, formaram-se

\footnotetext{
${ }^{4}$ Enredo linear é quando o tempo, o espaço e os personagens são apresentados de maneira ló gica e as ações desenvolvem-se cronologicamente, assim, observa-se o começo, o meio e o fim da narrativa (SILVA, Marina Cabral da. Enredo linear e não linear; Brasil Escola. S/d. Disponível em: <http://brasilescola.uol.com.br/redacao/enredo-linear-naolinear.htm>. Acesso em: jan. 2018.
} 
pequenos sítios e depois fazendas, constituindo-se assim centros de produção e consumo. O poder e a justiça eram provenientes do núcleo mais rico e seu proprietário era um verdadeiro patriarca. A família que o cercava, constituía a camada mais alta da sociedade rural. Logo abaixo, vinham os artífices, mecânicos e tecelões que formavam uma classe intermediária e no degrau mais baixo os índios e posteriormente os escravos. Nessa época, a transmissão dos conhecimentos profissionais era feita nas rudimentares oficinas e de acordo com as necessidades.

Os Jesuítas foram os precursores do processo de educação no Brasil e sua doutrinação baseava-se principalmente em difundir a religião católica e a instrução. O Ratio Studiorum ${ }^{5}$ de 1599 era um vasto plano pedagógico. "E como havia poucos artífices, os missionários foram também mestres de ofícios, formando numerosos discípulos nas artes de tecelagem, da carpintaria, da ferraria ou da sapataria" (ibid., p. 20). Os primeiros aprendizes de ofícios no Brasil foram os índios e os escravos. Fonseca destaca que isso marcou com o estigma de servidão o início do ensino industrial em nosso país.

$\mathrm{Na}$ Europa, as corporações de ofício surgem na Idade Média. "Hierarquicamente falando, os ofícios se estruturavam em três categorias: mestres, oficiais e aprendizes. A reunião dos mestres de um mesmo ofício é que formava a corporação daquele ofício" (ibid., p. 29-30). A vida penosa do menor aprendiz começava geralmente dos doze aos quatorze anos, e seu tempo de aprendizagem era de quatro anos. Para atingir o título máximo de mestre eram necessários cerca de nove anos de estudos e trabalho.

Fonseca destaca que a religião católica era a base de toda a estrutura das corporações. Com o advento do Renascimento, isto era um fator que dificultava o progresso da indústria. Ou seja, era uma contradição, pois, ao mesmo tempo em que as Corporações de Ofícios tinham se transformado em elemento propulsor das manufaturas, elas impediam o seu progresso.

Em Portugal, elas não se estabeleceram da mesma forma que no resto da Europa. Com o aparecimento das fábricas e o seu incipiente desenvolvimento industrial, decresceu o prestígio das corporações que foram extintas de Portugal em 1834. No Brasil não se sabe quando começaram as Corporações de Ofício. No entanto, Fonseca destaca que em 1603 o rei Filipe I, instituiu o "Código Filipino" que vai regulamentar o trabalho profissional e impor taxas ao trabalho profissional de vários artífices (denominados de oficiais mecânicos) e sapateiros. As Câmaras eram as responsáveis por organizar os ofícios e no Brasil elas ficaram conhecidas como "Bandeiras dos Ofícios" ${ }^{\circ}$. Nesta época

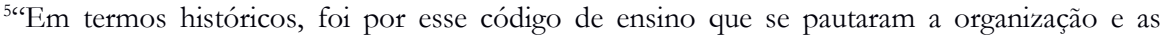
atividades dos numerosos colégios fundados e dirigidos pela Companhia de Jesus. Essas instituições multiplicaram-se rapidamente, chegando a um total de 728 casas de ensino em 1750, nove anos antes da expulsão dos jesuítas do Brasil e dos demais domínios portugueses, e 23 anos antes da supressão da Ordem pelo papa Clemente XIV” (SAVIANI, 2010, p. 57).

6 "A forte influência religiosa junto às corporações e as obrigações religiosas que os oficiais mecânicos das diversas profissões passaram a exercer - especialmente pela representação desempe-
} 
a indústria no Brasil era quase nula. As Corporações de Ofícios aqui foram extintas após a Independência, em 1824.

A economia brasileira no período colonial se estruturava principalmente na produção do açúcar, e os engenhos polarizavam a aprendizagem de ofícios, chegando o Brasil a ser no século XVII o maior produtor mundial do produto. No entanto, com a descoberta do ouro em Minas Gerais, ocorre uma mudança importante na estrutura econômica e social do país. No final do século dezessete há uma transferência das atividades econômicas do Nordeste para o Sudeste. O ouro fez com que aparecesse uma nova modalidade de ensino profissional. Como afirma Fonseca "homens experimentados deveriam ensinar aos aventureiros a melhor maneira de examinar o metal e lavrar as minas" (ibid., p. 79).

A partir do momento que as autoridades portuguesas passam a exigir o pagamento do "fisco" (imposto), apareceram as Casas de Fundição e de Moeda "onde se transformava o ouro em barra e se cunhava, aproveitando a oportunidade para cobrar a taxa devida" (ibid., p. 80). É importante destacarmos a discriminação social que surge com este novo ofício que era dirigido aos homens brancos da sociedade e não podia ser realizado por negros. Surgia assim um novo ofício, o fundidor ou moedeiro, com uma aprendizagem parecida com as dos engenhos de açúcar.

O autor destaca a diferença da aprendizagem nos Engenhos de Açúcar da aprendizagem feita nas Casas da Moeda. A aprendizagem nos Engenhos dava-se de modo inteiramente assistemático e os candidatos não precisavam provar os conhecimentos práticos por meio de exames. Mas na aprendizagem nas Casas da Moeda, os aprendizes, no final de um período de cinco a seis anos, passavam por exames, ou seja, "ficavam sujeitos a demonstrar as suas habilitações perante uma verdadeira banca examinadora constituída por dois membros, e pediam, no final, que se lhes passasse uma certidão de aprovação, uma espécie assim dos modernos diplomas" (ibid., p.81). Após esse exame, os aprendizes brancos, ao serem considerados capazes, seriam admitidos na Casa da Moeda, "vencendo salário e fazendo parte do quadro do respectivo pessoal" (ibid., p. 81).

No ano de 1763 o Brasil passou à categoria de Vice-Reino e, no Rio de Janeiro, foi criado o Arsenal da Marinha que passou a ser um importante foco de aprendizagem de ofícios para os interessados na construção naval. Segundo Fonseca, "a maioria dos operários constituía-se de brancos e portugueses, [...] e traziam para o serviço seus escravos a fim de os auxiliarem nas diferentes tarefas profissionais" (ibid., p. 89-90). Os presos e 'vagabundos' também eram recrutados para o serviço no Arsenal.

nhada nas procissões, nas quais cada ofício carregava a bandeira do respectivo santo protetor -, explica a designação que receberam de bandeiras. E, neste caso, as bandeiras dos ofícios funcionavam com uma rigorosa hierarquia profissional" (MARTINS, 2017). 
Para o autor, foi incontestável a importância dos Arsenais da Marinha para a transmissão dos conhecimentos manuais, reduzidos aos conhecimentos práticos, porque não havia uma preocupação com os conhecimentos teóricos. E isso é uma questão importante que acompanha a nossa história, perpassando o período da Colônia, do Império e da República, com repercussão até os dias de hoje na desvalorização do trabalho manual.

A vinda da Corte portuguesa para o Brasil em 1808 promoveu grandes realizações na economia, na política e na cultura, influenciando diretamente o setor de ensino de ofícios. Com a abertura dos portos ao comércio estrangeiro e a permissão de instalação de fábricas no Brasil, lançaram-se os fundamentos da era industrial. Em 1809, é criado o Colégio das Fábricas, por D. João VI, com a finalidade de fornecer educação aos artistas e aprendizes que vinham de Portugal, atraídos pela permissão de criação de indústrias no Brasil. Ocorre também neste período, a criação da Companhia de Artífices ${ }^{7}$, que posteriormente vai promover uma intensa aprendizagem no Arsenal de Guerra do Rio de Janeiro.

Diferente foi o desenvolvimento da intelectualidade brasileira, que se deu, principalmente, a partir da implantação da Imprensa Nacional, que introduziu as oficinas gráficas, incluindo aprendizes na Real Impressão. O que vemos, diante da preocupação da Corte Portuguesa em formar artífices, é a evolução das condições da vida, que passava por uma transição das áreas rurais ao agrupamento nas cidades, e a uma melhor organização da vida econômica.

Diante da divisão de classes, desde o início, não é de estranhar, que o ensino profissional fique pouco a pouco destinado exclusivamente aos "deserdados da sorte, os desamparados, os infelizes" (ibid., p. 113). Em 1818, por exemplo, em Olinda, criou-se o Seminário dos Órfãos que marca o início de uma longa série de estabelecimentos destinados a recolher órfãos e dar-lhes ensino profissional. Também na Bahia é criado o Seminário dos Órfãos com o mesmo intuito.

No período próximo à Independência, começam a surgir as primeiras fábricas no Brasil. Entre elas, fábricas de massas alimentícias, tecidos de algodão, destilaria, pólvora, etc. Surgem também neste período, pequenas instalações industriais denominadas oficinas. Produziam, por exemplo, calçados, tamancos, pequenos objetos de uso doméstico, tipografias, entre outros. No ano da Independência, em 1822, D. Pedro I criou um novo regimento para os aprendizes da Tipografia Nacional, conhecida posteriormente como Imprensa Nacional.

Após a Independência, o Império foi instituído, marcando a vitória do pensamento liberal sobre a mentalidade conservadora. Os debates travados na Assembleia Constituinte de 1823, buscavam uma nova orientação para a edu-

\footnotetext{
7 “A Companhia de Artífices tinha uma organização perfeitamente militar, com subordinação, uniforme e ordem de formatura, como se fora uma unidade qualquer da tropa. Os mestres equivaliam a sargentos e os contramestres a cabos de esquadra" (ibid., p. 105).
} 
cação. Fonseca destaca que no tocante ao ensino de ofícios, não houve nenhum progresso. "A mesma mentalidade, o mesmo pensamento de destinar aquele ramo de ensino aos humildes, aos pobres, aos desvalidos, continuava a imperar" (ibid., p. 135). A Constituição Outorgada em 1824 não tratava diretamente do ensino profissional, mas influenciou as suas diretrizes e seu desenvolvimento futuro. Uma de suas principais ações foi a extinção das Corporações de Ofícios no Brasil.

Outro marco definidor do ensino profissional no Brasil foi realizado pelo Ato Adicional de 1834, correspondendo ao desejo das Províncias de uma educação descentralizada. Elas ficaram responsáveis pelo ensino primário e secundário, legislando o governo central apenas quanto ao ensino superior. Em consequência, não tínhamos naquele período, uma política nacional de educação.

A fundação em 1837, no Rio de Janeiro, do Imperial Colégio D. Pedro II, teve uma grande importância para a educação brasileira. A sua função foi a "disseminação do ensino secundário, de caráter humanístico e literário" (ibid., p. 140).

Em 1854, foi fundado o Imperial Instituto dos Meninos Cegos, hoje Instituto Benjamim Constant e, dois anos mais tarde, criou-se o Imperial Instituto dos Surdos-Mudos. Em ambas as casas funcionavam oficinas para aprendizagem de ofícios. No Instituto Benjamim Constant, por exemplo, o ensino profissional era relativo aos trabalhos tipográficos em braile, obras de encadernação, afinação de pianos, entre outros. No Instituto dos SurdosMudos ensinava-se a fabricação de sapatos, encadernação, pautação e douração.

O autor destaca o Projeto de Lei nº. 236, em 1882, que incluiu a criação do ensino técnico nas Províncias. Entretanto, "o ensino industrial aparecia, assim, de mistura com o secundário, embora não trouxesse o acompanhamento indispensável da parte prática" (ibid., p. 156). Fonseca critica a passagem do ensino primário e do secundário para as províncias pois sucedera o inevitável:

[...] à falta de diretrizes gerais e de condições econômicas uniformes, a eficiência fora pequena; em vários casos, o ensino primário limitara-se, apenas, a ministrar leitura, escrita e contas. Enquanto isso, o ensino superior dilatara-se, expandira-se em quantidade e qualidade, formando uma nata de letrados, doutores e bacharéis, que ocupavam os principais postos da administração, da política e do magistério (ibid., p. 159-160).

Fonseca destaca a mentalidade da época que incentivava as profissões liberais, inundando o país de bacharéis que saíam do interior do país, e se con-

\footnotetext{
${ }^{8}$ Com o avanço da ciência e sua repercussão na linguagem, a instituição passou a chamar Insti tuto Nacional de Educação de Surdos (INES).
} 
centravam nas grandes cidades e ingressavam no serviço público. Acentua-se, assim a divisão das classes sociais.

No final da década, nos termos da lei da Abolição, acabaria o trabalho escravo. A Proclamação da República, por sua vez, apresentou-se como um movimento político importante, pois propôs-se a abrir novos horizontes, indicando o início de outro ciclo na orientação da educação nacional.

No início do século XX, o conceito de ensino profissional era impreciso. Sentia-se a necessidade da interferência do Governo Federal no assunto. A proposição no 195 de 1906, feita pela Câmara dos Deputados, foi um marco na história do ensino industrial no Brasil, sendo o "primeiro documento oficial habilitando, com recursos financeiros, o poder público a iniciar, entre nós, as escolas profissionais do âmbito federal" (ibid., p. 170). Ocorria uma mudança de mentalidade por parte dos dirigentes do país, que começaram a entender a importância da criação de uma rede de institutos de ensino técnico e profissional para o progresso das indústrias.

A criação da Escola Prática de Aprendizes das Oficinas do Engenho de Dentro, em 1906, na Estrada de Ferro Central do Brasil foi outro marco importante. Havia no país um pensamento convergente para a implementação de um ensino visando possibilitar o desenvolvimento da indústria nascente. Exemplificando em números, na Proclamação da República em 1889 havia 636 estabelecimentos industriais no Brasil. Vinte anos depois, em 1909, foram fundados 3.362 outros. "A quantidade de operários empregados naquelas indústrias também crescera bastante. Em 1889 eram 24.369 homens e, em 1909, o número subira a 34.362" (ibid., p.174).

As tarefas nas indústrias exigiam homens com conhecimentos especializados, usando técnicas próprias. O então Presidente da República Nilo Peçanha, em 1909, através do decreto $\mathrm{n}^{\circ} .7566$ de setembro de 1909, cria nas capitais dos Estados, as Escolas de Aprendizes Artífices. Esse decreto, segundo Fonseca, representava o "marco inicial das atividades do governo federal no campo do ensino de ofícios" (ibid., p. 174). No entanto, continuava a ter o mesmo pensamento e posição, ele seria destinado aos pobres, aos humildes, os desfavorecidos pela fortuna.

No ano de 1917, a Prefeitura Municipal do Distrito Federal fundou a Escola de Artes e Ofícios Venceslau Brás com o objetivo de formar professores, mestres e contramestres, para atuarem nos estabelecimentos de ensino profissional. Posteriormente, a Escola deixou o âmbito municipal e passou à esfera federal, com o intuito de formar pessoal para todas as Escolas de Aprendizes Artífices do país.

Fonseca destaca que neste período, houve um projeto revolucionário sugerido pelo parlamentar Fidélis Reis, em 1922, defendendo o ensino profissional extensivo a todos, fossem pobres ou ricos. Este projeto, no entanto, como era de se esperar, teve forte oposição. 
Em 1934, Anísio Teixeira estava à frente do Departamento de Educação, e Joaquim Góes Filho fazia parte da Superintendência de Educação Geral e Técnica da Prefeitura do Distrito Federal. Eles desejavam lutar pela democratização do ensino, dando oportunidades a todos que quisessem estudar.

No pensamento dos "reformadores", estava a ideia da predominância da formação geral sobre a específica profissional. Eles acreditavam que há uma grande facilidade de se adaptar às necessidades técnicas que surgem no trabalho, por aqueles que possuem uma boa base de conhecimentos gerais.

O que importava, o que valia era a iniciativa pessoal dos alunos, ou seja, a sua capacidade criadora e inventiva. Os cursos das escolas técnicas secundárias incentivavam, nos alunos, a formação de personalidades, o desenvolvimento do espírito de solidariedade e cooperação, assim como o incentivo ao senso prático, capacidade e interesse pela experimentação científica, e hábitos de saúde, leitura e trabalho.

Em 22 de janeiro de 1942, através do Decreto-Lei no. 4.048, o Governo Federal criou o Serviço Nacional de Aprendizagem Industrial (SE$\mathrm{NAI})^{9}$. O artigo $1^{\circ}$. desse regimento estipulava que o SENAI ficaria subordinado ao Ministério da Educação, cujo Ministro era Gustavo Capanema, mas seria dirigido pela Confederação da Indústria. O Ministério da Educação, por sua vez, fixaria as diretrizes pedagógicas do ensino dos cursos de aprendizagem de todo o país e faria a fiscalização. Logo, o Ministério da Educação ficava com a função normativa, enquanto que a parte executiva era entregue aos industriais. O que não deixava de ser, uma contradição.

Em 30 de janeiro de 1942, fez aprovar a Lei Orgânica do Ensino Industrial pelo Decreto-lei n. 4.073, que alterou profundamente a organização e a filosofia da educação profissional. Até 1942 o ensino profissional no Brasil não possuía regras que valessem para todo o território nacional. Como afirmamos, a União, até o momento regulamentava somente as escolas federais. Os estabelecimentos estaduais, municipais e particulares faziam suas próprias normas ou obedeciam a regulamentação de caráter regional. A partir deste documento, definem-se não só as bases pedagógicas da educação profissional, assim como o funcionamento das escolas e as normas gerais.

\section{A escrita da história e algumas de suas categorias}

Ao lermos um clássico da historiografia educacional brasileira, principalmente no campo da formação profissional no Brasil, percebemos que Fonseca não se detém em teorizar sobre os conceitos e categorias. Sua obra revela a importância dos fatos, das datas, dos locais, das pessoas importantes e das fontes que utiliza em sua pesquisa, o que faz a sua obra densa de historicidade.

\footnotetext{
9 Para maiores detalhes ver "O SENAI" em FONSECA (1986., vol. 3); e LIMA, (2007) sobre o SENAI e os paradigmas da produção industrial no Espírito Santo 1948 / 1999.
} 
Mas é preciso situá-la na história factual e em seu critério de verdade de adequação do relato aos acontecimentos. O objetivo deste artigo não é criticar ou estereotipar o pensamento do autor, esboçado em sua obra, mas sim, o de reunir possíveis categorias implicitamente presentes, que possam contribuir para compreendermos como sua escrita revela a história de ensino profissional.

Procuramos não aprisionar o pensamento de Fonseca, e sim, fazer uma análise de como ele escreve a história da educação profissional a partir de algumas categorias relevantes na obra. Nossa análise tem por base o materialismo histórico dialético, segundo o qual nenhum fenômeno pode ser compreendido isoladamente, pois é resultado do momento histórico, econômico, social e cultural que o circunscreve (MARX, 1982; CIAVATTA, 2015) e da história como produção social da existência (MARX; ENGELS, 2007).

Neste sentido, ao tratarmos a história como processo, as categorias ganham relevância, uma vez que o nível teórico e a acumulação de conhecimento que lhe dá sustentação passam a adquirir qualidade de um conceito, tendo assim a capacidade de explicar a realidade (CIAVATTA, 2015). Escolhemos trabalhar com as categorias: contradição, classes sociais e ensino industrial. As duas primeiras categorias não aparecem explicitamente no livro do autor, mas pode-se perceber que essas categorias perpassam o texto indiretamente, enquanto a categoria ensino Industrial é o fio condutor da obra. É importante ressaltarmos que não pretendemos esgotar todas as categorias e conceitos. Discutiremos essas categorias, buscando explicar os respectivos significados teóricos e práticos, relacionando-os como elas se articulam no pensamento de Fonseca.

\subsection{Contradição}

Marx distingue a contradição fundamental da sociedade capitalista "Entre o caráter social da produção e o caráter privado da propriedade".

Marx e Engels aplicaram a lei da contradição inerente aos fenômenos,
ao estudo do processo da história da sociedade, descobriram a con-
tradição existente entre as forças produtivas e as relações de produção,
a contradição entre as classes dos exploradores e dos explorados, assim
como a contradição existente entre a base e a superestrutura (política,
ideologia etc.); e descobriram como essas contradições engendravam
diferentes espécies de revoluções sociais nas diferentes espécies de so-
ciedades de classes (Mao Tse-tung, 2001, apud, Ciavatta, 2015, p. 43).

Essa contradição nas forças produtivas, pode ser observada na passagem em que, 
[...] terminados os quatro anos de aprendizado e recebido o "certificado de saída", passava a oficial aquele que iniciaria sua carreira como aprendiz. Sua vida, entretanto, permanecia a mesma, pois continuava a habitar a casa do mestre, começando, contudo a receber um salário compatível com a sua nova função, e que era igual ao de todos os oficiais da mesma profissão (FONSECA, 1986, p. 33).

Como ressalta Ciavatta na filosofia clássica, contradição é a oposição entre uma proposição afirmativa e outra negativa. Ou seja, elas são incompatíveis entre si.

Para Hegel, a contradição é o momento necessário da dialética,

[...] é o movimento da realidade em transformação, afirmando que o ser é e não é ao mesmo tempo, ao nível do pensamento e do real, porque o mundo externo está em permanente transformação. Para o filósofo idealista, o movimento se realiza em três fases: tese, antitese e sintese, 'que marcam o progresso da consciência e o movimento da história até o espirito absoluo' (Hegel, 1990, grifos do autor, apud Ciavatta, 2015, p. 43).

Nesta perspectiva, "se conjugarmos essa análise ao conceito de mediação, veremos que os processos sociais ou as mediações que constituem toda e qualquer realidade estão sempre em um movimento de transformação", sendo assim, a contradição tem o "sentido de movimento, que pode ser também de conflito, de um choque de ideias, de interesses e de ações" (CIAVATTA, 2015, p. 44).

Fonseca ao narrar, em seu livro, sobre o ensino industrial no Brasil, parte da explicação das Corporações de Ofícios, na Idade Média, ressaltando que para os aprendizes adquirirem algum ofício, teriam que ingressar em uma corporação, onde um mestre ensinaria os segredos da profissão. Mas para que isso acontecesse, os responsáveis pelos menores aprendizes, assinavam um contrato, que segundo Fonseca nem sempre eram cumpridos "porque comumente, se viam os aprendizes transformados em verdadeiros empregados domésticos dos mestres, muitos dos quais deixavam de ensinar certos aspectos de suas técnicas com receio de se verem suplantados pelos discípulos" (FONSECA, 1986, p. 31). Havia um conflito de interesses entre o mestre e o aprendiz e a submissão do aprendiz às tarefas estranhas ao aprendizado.

Para Ciavatta,

Marx inscreve a concepção de contradição de Hegel no mundo real. Para ele, 'a contradição é o conflito histórico entre as forças produtivas e as relações de produção, devendo culminar na revolução suscetível de mudar um regime social [um modo de produção] para outro (Marx, 1980, apud Ciavatta, 2015, p. 43). 
São várias as contradições encontradas nos acontecimentos tratados no livro de Celso Suckow da Fonseca, mesmo que elas não apareçam explicitamente. Uma delas é ele ter participado dos êxitos e autoritarismo do governo de Getúlio Vargas. Era um governo conservador da estrutura social brasileira. Mas, Fonseca era ao mesmo tempo, um humanista e acreditava que todos deveriam ter acesso ao conhecimento intelectual das atividades técnicoindustriais denunciando, em sua obra, a discriminação social oriunda do trabatho dos negros escravizados.

Outra contradição de classe revelada na obra de Fonseca é referente à criação do Seminário de São Joaquim no Rio de Janeiro, em 1818, que abria inscrição a "todos os rapazes de boa educação." No entanto, Fonseca deixa claro que "Não se dizia que aquela espécie de ensino era para os pobres, órfãos ou abandonados" (FONSECA, ibid., p. 113).

No Brasil, a eclosão da Primeira Guerra Mundial, em 1914, contraditoriamente, ocasionou dificuldades financeiras e econômicas. No entanto, a Guerra acabou beneficiando a indústria nacional, já que, como não se conseguia importar os produtos de que o país necessitava, implantaram-se algumas fábricas e indústrias. Elas não só incrementaram o mercado interno, como também possibilitaram que produtos brasileiros fossem comercializados para o mercado exterior.

\subsection{Classes Sociais}

O termo classe origina-se no "latim. classis: grupo convocado para as armas". No sentido lógico, "é um conjunto de seres, de objetos ou fatos, em número indeterminado, todos possuindo certas características comuns" (JAPIASSÚ; MARCONDES, 2006, p. 47).

O termo classe, em sentido sociológico, era denominado pelos antigos como "parte da cidade". Era assim designado

[...] um grupo de cidadãos definido pela natureza da função que exercem na vida social e pela parcela de vantagens que extraem de tal função. Platão, admitia três classes ou melhor, três partes da sua cidade ideal: a dos governantes ou filósofos, a dos guerreiros e dos agricultores e artífices; confiava à primeira a tarefa de distribuir os indivíduos entre as classes (Rep., III, 412 b ss., apud ABBAGNAMO, 2012, p.169).

Fazendo um contraponto com as Corporações de Ofício analisadas por Fonseca, em cada contexto e necessidade do Estado, percebemos que a hierarquia entre os cidadãos e os níveis de aprendizagem eram distintos. Em Portugal, por exemplo, as classes não se estabeleceram da mesma forma que no resto da Europa. Ou seja, em Portugal, a hierarquia estava organizada entre mestres, oficiais e aprendizes. No entanto, com o surgimento das fábricas e o 
seu incipiente desenvolvimento, diminui o seu prestígio e elas são extintas em 1834.

Fonseca destaca que:

[...] o fato de, entre nós, terem sido índios e escravos os primeiros aprendizes de ofícios marcou com um estigma de servidão o início do ensino industrial em nosso país. É que, desde então, habituou-se o povo de nossa terra a ver aquela forma de ensino destinada somente a elementos das mais baixas categorias sociais (FONSECA, 1986, p. 22).

Ao longo de todo o texto, o autor ressalta que o ensino e o trabalho manuais eram 'desonrosos' no Brasil, e esta mentalidade vai acompanhar todo o nosso processo político, econômico, social e cultural da Colônia à República. Por isso, os filhos dos colonos se afastavam de todo trabalho manual ou físico, chegando posteriormente a ser condição para desempenhar funções públicas, o candidato nunca ter trabalhado manualmente. Este fato gerou uma profunda divisão entre as classes ricas e pobres da sociedade brasileira.

A noção de classe ficou acentuada no séc. XVIII com a Revolução Francesa e todo movimento cultural que a acompanhou e, também, com o início do modo de produção capitalista. Hegel considerava a divisão de classes como um ajustamento necessário à sociedade civil, devido aos bens privados, ou seja, ao capital. "Hegel atribui às classes a função mediadora entre o governo e o povo; sua determinação exige delas tanto o sentimento de Estado e governo, quanto o dos interesses dos grupos particulares e dos indivíduos" (ABBAGNAMO, 2012, p. 170).

É consenso entre os autores ligados a diversas tradições políticas e intelectuais que é muito difícil encontrar uma definição de classe social. No entanto, todos estão de acordo que elas são uma consequência das desigualdades existentes na sociedade. Assim, por exemplo, o conceito de classe, foi introduzido, como instrumento analítico pelos estudiosos, com o fim de interpretar as transformações sociais que levaram à formação do proletariado industrial.

O conceito de classe envolve dois aspectos compatíveis entre si: de um ponto de vista teórico, serve para identificar os agrupamentos que emergem da estrutura das desigualdades sociais; de um ponto de vista histórico, serve para identificar os sujeitos do curso da história, ou seja, as coletividades que se apresentam como artífices do devir da sociedade no tempo (BOBBIO; MATTEUCCI; PASQUINO, 1993, p. 169).

Os dois aspectos compatíveis entre si, que envolvem o conceito de classe são explicitados quando Fonseca, descreve a aprendizagem nas Casas da Moeda, no Brasil, que era parecida com a que se realizava nos engenhos,

[...]sem método e sem caráter sistemático de ensino, diferia dela, entretanto, fundamentalmente, por se dirigir aos elementos brancos da sociedade, filhos de colonos ou de pequenos funcionários das próprias Casas 
onde se trabalhava o ouro. Além disso, surgia com o aspecto de preparo de pessoal para as necessidades do serviço, não aparecendo cercada das ideias de assistência a menores desvalidos, que mais tarde tolheriam o desenvolvimento do ensino de ofícios (FONSECA, 1986, p. 80).

O autor que explicita de forma clara a primeira elaboração teórica do conceito de classes é Marx. Ele a conceitua como expressão do modo de produzir da sociedade de forma que o próprio modo de produção vai ser definido pelas relações que se situam entre as classes sociais. Essas relações dependem não só da relação das classes como também dos instrumentos de produção (BOBBIO; MATTTEUCCI; PASQUINO, 1993).

A relação das classes com o modo de produção podemos ver em algumas passagens da obra de Fonseca:

A profissão de fundidor, e exercê-la em uma das Casas de Fundição não era coisa desinteressante, relativamente ao salário percebido, o que demonstra, também, que hierarquicamente a profissão, não podendo ser exercida por negros, estava bem conceituada (FONSECA, 1986, p. 84).

E também na passagem onde ele diz que

[...] a falta de homens para aquelas tarefas era enorme, fazia-se o recrutamento 'manu militari'. À noite saía uma patrulha do Arsenal e 'apenava' todo aquele que fosse encontrado vagando pelas ruas depois do toque de recolher. Algumas vezes a necessidade de pessoal era tanta, que se recorria ao Chefe de Polícia, pedindo-se-lhe que enviasse, dos seus presos, aqueles que estivessem em condições de produzir algum trabalho profissional (ibid., p. 90, aspas do autor).

Em todo o livro, Fonseca destaca com veemência que o ensino profissional era destinado aos deserdados da sorte, aos desamparados, aos infelizes. Como exemplo, podemos citar a criação do Seminário dos órfãos, em 1818, em Olinda, e o Seminário dos Órfãos na Bahia com o mesmo intuito de recolher órfãos para dar-lhes ensino profissional. Ocorre, assim, uma fundamental e clara separação de classe. De um lado uma minoria rica e instruída, convivendo com a grande maioria do povo analfabeto, responsável pelas tarefas difíceis e pesadas. Como observamos ao longo do trabalho de Fonseca, esse conceito antidemocrático do ensino de ofícios vai se perpetuar até depois do advento da República. 


\subsection{Ensino Industrial}

A categoria Ensino Industrial é o fio condutor na obra de Fonseca, já que ele reconstrói, desde os seus primórdios no Brasil, a relação entre as atividades produtivas e a preparação para o trabalho. Há uma clara separação da oferta de trabalho e de educação, de acordo com a classe social. As atividades braçais e manuais eram destinadas aos negros, pobres e desvalidos. As atividades intelectuais eram reservadas aos filhos dos latifundiários e dos burocratas da Colônia e do Império.

Segundo Ciavatta,

[...] a historicidade da Educação Profissional, em uma concepção dialética do espaço-tempo, trata dos fenômenos sociais da vida humana na sua temporalidade complexa, a exemplo dos tempos múltiplos de Braudel (1982), quando fala da longa duração da estrutura, da média duração da conjuntura e do tempo breve dos acontecimentos (CIAVATTA, 2015, p. 33).

Sem citar Braudel, Fonseca transita por essa temporalidade múltipla ao trazer da Colônia para o tempo de sua escrita, os diversos acontecimentos que alteraram, ao longo dos séculos as estruturas da sociedade brasileira, mantendo a separação das classes sociais e seus aprendizados profissionais. Também sem mencionar o fenômeno da contradição latente na sociedade capitalista, expõe os nexos contraditórios entre o capital e o trabalho, intimamente relacionados a uma sociedade de classes e à divisão social do trabalho e à apropriação dos produtos do trabalho (MARX, 2008).

O estudo da gênese da relação entre trabalho e educação, evidencia que ela ocorre em uma dupla dimensão. "O trabalho tem um sentido ontológico, de atividade histórica, criativa e fundamental da vida humana; e tem formas históricas, penosas, socialmente produzidas, particularmente, no espaço das relações capitalistas" (LUKÁCS, 2010, apud CIAVATTA, 2015, p. 35). Historicamente, a educação profissional ocorre "a serviço de interesses e valores do mercado, não convergentes com o seu sentido fundamental de formação humana, potencializadora do desenvolvimento pleno do ser humano (GRAMSCI, 1978b, apud CIAVATTA, 2015, p. 35).

Fonseca também não se detém no tratamento do termo "ensino industrial" que dá nome a seu livro, mas todo livro é permeado pelo sentido original, denso de história, do termo "indústria". Do latim industria, a palavra vem do verbo indo (vestir), do nome indusium (vestido) e guarda o sentido de atividade, aplicação, assiduidade ${ }^{10}$ (GAFFIOT, 1934). Em português é um termo rico de significados, ${ }^{11}$ bem expressos por Fonseca na sucessão de fatos e medidas que, ao longo dos séculos, dá forma ao ensino industrial.

${ }^{10}$ GAFFIOT, Felix. Dictionaire ilustré. Paris: Librerie Hachette, 1934. 
No último capítulo do $1^{\circ}$. Volume, o autor trata das iniciativas que alimentaram o desenvolvimento industrial no país e "a tese da industrialização das escolas" (FONSECA, id., p. 167).

A proposição 195, de 1906, da Câmara dos Deputados, deve ser saudada como um marco na história do ensino industrial no Brasil, uma vez que representa, na República, o primeiro documento oficial habilitando, com recursos financeiros, o poder público a iniciar, entre nós, as escolas profissionais de âmbito federal. (ibid., p. 170, grifo nosso).

A passagem dos ofícios e da manufatura para os processos da Revolução Industrial, para a produção capitalista e a existência do proletariado na Europa, não era um fato alheio ao conhecimento das elites no Brasil. É um período de transição da produção artesanal para a produção por máquinas, além de novos produtos químicos e da exploração de novas fontes de energia. Para Hobsbawn (1982), "pela primeira vez na história da humanidade, foram retirados os grilhões do poder produtivo das sociedades humanas, que daí em diante se tornaram capazes da multiplicação rápida, constante, até o presente ilimitada, de homens, mercadorias e serviços" (p. 44) ${ }^{12}$.

No Brasil, as transformações ocorridas com a vinda de D. João IV, em 1808, possibilitaram a abertura dos portos para o comércio estrangeiro, e no mesmo ano foi permitido a instalação de fábricas. Estavam, assim, sendo lançados, os fundamentos da era industrial. Esse período "[...] haveria de marcar uma época de grandes realizações nos campos da economia e da cultu$\mathrm{ra}$, as quais iriam influenciar extraordinariamente os destinos de nossa terra, inclusive no setor do ensino de ofícios" (FONSECA, 1986, p. 99).

Ainda no período anterior à Independência, tinham começado a surgir pequenas instalações industriais, chamadas de oficinas como a de: calçados, tamancos, esteiras, pequenos objetos de uso doméstico, cerâmicas de barro e pequenas tipografias. A Constituição outorgada de 1824 deu uma nova organização à aprendizagem de ofícios.

Cunha (2000), escrevendo sobre "O ensino de ofícios nos primórdios da industrialização", fala sobre a ideologia do industrialismo vigente na época:

\footnotetext{
${ }^{11}$ Em português significa: "1. Destreza ou arte na execução de um trabalho manual; aptidão, perícia. 2. Profissão mecânica ou mercantil; ofício;.3. Fig. Invenção, astúcia, engenho. 4. Em econ. Atividade de produção de mercadorias, especialmente de forma mecanizada e em grande escala, abrangendo a extração de produtos naturais (indústria extrativa) e sua transformação (indústria de transformação). 5. O conjunto das empresas industriais; o complexo industrial (AURÉLIO. Novo dicionário. S. 1.: Positivo, 2004, digital).

${ }^{12}$ Sobre as grandes Revoluções, inclusive, a Revolução Industrial, nas primeiras décadas do século XIX, v. Hobsbawn, 1982.
} 
O industrialismo consistia na atribuição à indústria de sinônimo de progresso, emancipação econômica, independência política, democracia e civilização. Seus adeptos esperavam que a indústria conduzisse o Brasil ao nível das nações civilizadas, pois ela levaria o país a possuir aqueles atributos próprios dos países da Europa e dos Estados Unidos (p. 14).

No mesmo ano de 1906, é criada a Escola Prática de Aprendizes das Oficinas do Engenho de Dentro na Estrada de Ferro Central do Brasil. É importante ressaltar que as necessidades das indústrias eram muito complexas, principalmente para a sociedade da época. As tarefas exigiam conhecimentos especializados, serviços com técnicas próprias. Tornava-se cada vez mais necessário o estabelecimento do ensino profissional.

Rodrigues (1998) ao tratar da atuação da Confederação Nacional da Indústria (CNI), destaca "a inegável e forte presença da burguesia industrial no debate educacional brasileiro" (p. 11) $)^{13}$.

Como apresentamos, na reconstrução histórica do ensino industrial no Brasil, no livro de Fonseca, há um conjunto de iniciativas governamentais que, sem mudar a natureza dual da sociedade e da educação que era oferecida à população trabalhadora, estabelece marcos educacionais com avanços no sistema de ensino profissional, mas que respondiam às necessidades dos empresários.

Fonseca (ibid.) lamenta que as Escolas de Aprendizes Artífices, criadas em 1909, pelo Presidente Nilo Peçanha, estivesse marcada pelo "velho preconceito que emprestava à aprendizagem de ofícios a feição secular que a destinava aos pobres e humildes [...] 'aos desfavorecidos da fortuna"' (p. 177), referindo-se ao caput da Lei (Decreto n. 7566/1909). Mas reconhece que as Escolas representaram um marco na aprendizagem de ofícios e mais tarde daria seus 'frutos' sob a forma das modernas escolas industriais e técnicas do Ministério da Educação. Em 1937, o Ministro Gustavo Capanema vai reformar o Ministério da Educação e Saúde Pública, e as Escolas de Aprendizes Artífices, passaram a ser chamadas de Liceus.

A Constituição de 1937, ainda sob o regime ditatorial, no governo de Getúlio Vargas, instituiu a cooperação entre a indústria e o Estado e manteve "o ensino pré-vocacional e profissional destinado às classes menos favorecidas" (Art. 129). Ou seja, a destinação de origem quase nada havia mudado desde o início do século XX. A Lei Orgânica do Ensino Industrial (Decretolei n. 4.073/1942) vai alterar a organização e a filosofia sobre o ensino das escolas técnicas e profissionais. $O$ ensino deixou de ser ensino estanque e, mesmo com limites para passar de uma rede a outra, passou a se interligar com o

\footnotetext{
13 “A CNI, fundada em 1938, constituiu-se como o mais importante órgão de representação da burguesia industrial brasileira, saltando do tímido Centro Industrial do Brasil (CIB), fundado em 1904, para a imponente Confederação que representa 27 federações, cobrindo todo o território nacional.” (RODRIGUES, 1998, p 7).
} 
restante do sistema educacional. No mesmo ano, sob a pressão dos empresários junto ao Ministério do Trabalho, o Presidente Vargas criou o Serviço Nacional da Aprendizagem Industrial (SENAI) (Decreto-lei n. 4.936/1942), obrigando aos empregadores manterem em seus estabelecimentos com mais de 500 empregados, "uma certa percentagem de aprendizes ganhando salário pelas horas em que aprendessem ofícios em escolas custeadas pela indústria e sindicatos" (FONSECA, 1986, V.3, p. 18-19).

$\mathrm{O}$ dualismo esteve presente na educação brasileira durante vários séculos e permanece aos dias atuais. Apenas na metade do século XX, o analfabetismo se coloca como uma preocupação e se torna objeto de políticas de Estado.

Esse dualismo toma um caráter estrutural especialmente a partir da década de 1940, quando a educação nacional foi organizada por leis orgânicas. A Lei Orgânica do Ensino Secundário de 1942, promulgada durante o Estado Novo, na gestão de Gustavo Capanema, acentuava a velha tradição do ensino secundário acadêmico, propedêutico e aristocrático juntamente com esta havia o conjunto de leis orgânicas que regulamentaram o ensino profissional nos diversos ramos da economia, bem como o ensino normal (FRIGOTTO; CIAVATTA; RAMOS, 2005, p. 32).

$\mathrm{Na}$ década seguinte, sob a pressão da população pelo acesso ao ensino secundário e superior, a Lei 3.552/1959, reorganiza o ensino industrial, dando outra finalidade ao primeiro ciclo do ensino industrial, ao permitir autonomia didática, administrativa e financeira às escolas ${ }^{14}$. "As novas diretrizes traçadas para o ensino industrial deverão influir na harmonia social do país, pois constituem um meio de miscigenação de classes, um fator de equilíbrio das massas populares" (FONSECA, 1986, V.5, p. 203).

Fonseca não deixa de ressaltar que era importante era dar aos alunos/ trabalhadores da indústria não só instrução profissional, mas educação no seu sentido mais geral. "Olhado por esse prisma, o ensino industrial assume um aspecto que o recomenda aos olhos dos governos verdadeiramente democratas, pois sua expansão será decisiva no equilíbrio social da nação" (ibid., p. 204).

Para a análise da categoria ensino industrial, no livro de Fonseca, não podemos deixar de nos reportar a Marx e Engels (1979), que nos ensinaram que a história é a produção social da existência. Devemos, assim, abrir "uma janela de possibilidades para a compreensão não apenas dos grandes feitos, mas de todos os fenômenos da vida, de todas as classes sociais, da vida e da educação profissional dos trabalhadores" (CIAVATTA, 2015, p. 33).

\footnotetext{
${ }^{14}$ Sobre as chamadas Leis de Equivalência do ensino profissional e técnico ao ensino secundá rio e acesso ao ensino superior, v. Ciavatta, 2009 (p. 389 e ss.).
} 
Devemos também entender de forma dialética o sentido e a natureza das transformações das políticas e das práticas sociais, de acordo com seu tempo histórico, como fez Fonseca. Mas "a complexidade da apreensão do sentido e da natureza dessas mudanças do trabalho se amplia quando o tecido estrutural da sociedade, em suas múltiplas dimensões, apresenta tensões e mudanças abruptas e profundas, sem que haja uma ruptura do modo de produção" em que elas se realizam (CIAVATTA, ibid., p. 35).

\section{Considerações finais}

O livro História do Ensino Industrial no Brasil de Celso Suckow da Fonseca é um clássico da historiografia educacional brasileira, principalmente na perspectiva da educação profissional. $\mathrm{O}$ autor pesquisou longamente, resultando em uma obra de vários volumes na segunda edição, em 1986. Destacamos, neste estudo do $1^{\circ}$. Volume, a abundância de fontes primárias e secundárias, como: leis, decretos, regimentos, regulamentos, entrevistas, o que permitiu ao autor escrever a história do ensino industrial de maneira cronológica e articulada aos acontecimentos do ensino dos ofícios manuais, técnicos e industriais do Brasil, desde a chegada dos portugueses até o início da República, localizando-os no seu tempo-espaço. Buscamos aprofundar o uso de três categorias presentes na obra: contradição, classes sociais e ensino industrial.

Não havia, nas épocas tratadas pelo autor, a preocupação em ensinar os conhecimentos teóricos, científicos e humanísticos próprios à educação dos filhos das elites; priorizava-se o ensino de conhecimentos práticos. Mas Fonseca destaca que entre os séculos XVI e XVII, começa a surgir na Europa uma nova mentalidade visando unir as operações manuais ao ensino intelectual. Como representantes dessa geração, cita: Comenius, Locke e Rousseau.

Mas o autor reitera que, no Brasil, o início do ensino industrial é marcado com o estigma da servidão. Como os nossos primeiros aprendizes foram os índios e depois os escravos, os trabalhos manuais eram considerados 'desonrosos' e essa maneira de pensar vai acompanhar todo o processo político, econômico e social do país, ao longo dos séculos.

A obra de Celso Suckow da Fonseca tem sido uma referência fundamental para os pesquisadores, do campo de estudos sobre o Trabalho-Educação, particularmente, a educação profissional, a exemplo de Cunha (2000, entre outras), Ciavatta (2009, entre outras). Ao longo do artigo procuramos elucidar algumas posições e embates políticos que permearam esse importante tratado histórico da educação profissional em nosso país desde a chegada dos Portugueses em 1500 até as décadas iniciais da República. 


\title{
O PASSADO ESCRAVISTA NO PRESENTE: a Sociologia histórica de Luiz Antonio Cunha - uma releitura ${ }^{*_{1}}$
}

\author{
Maria Ciavatta \\ Renata Reis
}

\section{Introdução}

\begin{abstract}
"Passou-se de um temor de que os escravos libertados se recusariam a trabalhar, salvo se fossem educados para isso. Em decorrência, a abolição da escravatura deveria ser gradual, não só para evitar que a produção fosse prejudicada, isto é, que os senhores perdessem sua força de trabalho cativa, como também para dar tempo para a educação dos escravos [...]" (CUNHA, 2000a, p. 181).
\end{abstract}

Apresentaremos aqui uma análise do livro de Luiz Antônio Cunha " $O$ ensino de oficios artesanais e manufatureiros no Brasil escravocrata" (2000a) que abrange a preparação para o trabalho, do Brasil Colônia ao início do século XX. O livro é o primeiro de uma trilogia que aborda o ensino de ofícios no Brasil escravocrata, nos primórdios da industrialização e o ensino profissional na irradiação do industrialismo (CUNHA, 2000 a, 2000b, 2000c).

Embora a história dos processos produtivos e sua relação com a vida dos trabalhadores seja inerente às relações entre o trabalho e a educação, poucos são os pesquisadores desta área de estudos que tratam do tema em termos historiográficos. O professor Luiz Antônio Cunha traz uma valiosa e indispensável contribuição à historiografia da educação profissional brasileira remontando à sua gênese a partir de fontes primárias e secundárias.

Este texto está assim organizado: no primeiro ponto apresentamos o autor, sua obra, as fontes de pesquisa utilizadas e a sociologia histórica ou história social na obra em análise. Em segundo lugar, a herança escravista na educação do presente. O terceiro ponto abordará tempo e espaço, categorias fundamentais da historicidade. E por fim, a reconstrução histórica e algumas categorias selecionadas: a herança escravista no presente; escravos, libertos e o aviltamento do trabalho manual; a organização do trabalho e o ensino de ofícios artesanais e manufatureiros; o trabalho e a educação para o trabalho.

\footnotetext{
*DOI - 10.29388/978-85-53111-86-2-f.79-96

${ }^{1}$ Este capítulo é parte da pesquisa desenvolvida no Projeto CIAVATTA (2012) O texto é uma releitura da obra e do artigo (CIAVATTA; REIS, 2016) após a realização do Colóquio "A Historiografia em Trabalho-Educação", que aconteceu nos dias 08 a 10 de novembro de 2017 na Faculdade de Educação da UFF, com a presença do autor do livro.
} 


\section{Luiz Antônio Cunha: sociólogo historiador da educação}

Luiz Antonio Constant Rodrigues da Cunha é um cientista social mineiro formado em 1967 pela PUC do Rio de Janeiro. Em seu mestrado, concluído em 1972, na mesma instituição, a dissertação teve como título "O Ensino Técnico industrial e a profissionalização do Ensino médio" (CUNHA, 1973), orientada por Claudio de Moura Castro, economista, do qual seu extenso trabalho intelectual se distancia pela análise sociopolítica da educação brasileira. No ano de 1980, concluiu o doutorado em Filosofia da Educação pela Pontifícia Universidade Católica de São Paulo. Sua tese teve como título "A Universidade Crítica" (CUNHA, 2007), orientado por Dermeval Saviani.

Depois de exercer o magistério na PUC-Rio, na FGV, na Unicamp, na UFF, na FLACSO, atua, desde 1997, como professor titular da Universidade Federal do Rio de Janeiro, onde recebeu o título de Professor Emérito da UFRJ. Tem experiência na área de Sociologia, principalmente nos seguintes temas: política educacional, educação brasileira, ensino técnico, história da educação, ensino superior e a laicidade do Estado, hoje, seu objeto principal de pesquisa.

Autor de referência para muitos mestres, doutores e pesquisadores, em nível nacional, considerado por Saviani (2013) um "pesquisador da dualidade escolar", Luiz Antônio Cunha evidencia a dualidade presente na escola brasileira através de suas pesquisas históricas, tanto para o ensino superior, quanto para a educação profissional.

Para a realização do estudo de que trata este artigo, Cunha (2000a) cita, de modo particular, a "obra monumental" de Celso Suckow da Fonseca como "referência básica e interlocutora permanente" (p. 4). O autor recorreu a diversos documentos históricos do período, que abrange desde o Brasil Colônia até as vésperas da Proclamação da República, tais como decretos, relatórios governamentais, cartas, manuscritos; suas próprias pesquisas sobre aprendizagem e as raízes das escolas de ofícios manufatureiros, o ensino de ofícios manufatureiros em arsenais, asilos e liceus.

Assinala ainda que contribuíram, direta ou indiretamente, na pesquisa para a obra em foco neste trabalho: os professores Joaquim Faria Góes Filho e Roberto Hermeto Corrêa da Costa da FGV, estagiários e bolsistas do IESAE/FGV, os professores Lea Pinheiro Paixão, Dermeval Saviani, José Oliveira Arapiraca, Luís Carlos Soares e Gisélia Lima Azzedino. Valiosos também foram os acervos da Biblioteca Nacional, do Instituto Histórico e Geográfico do Brasil e do Arquivo Nacional.

A partir da argumentação do historiador Peter Burke (1991), consideramos de sociologia histórica ou de história social, o extenso e denso trabalho de Luiz Antônio Cunha sobre a educação profissional no Brasil. Esta classificação no campo científico da sociologia e da história está presente também na obra do autor. 
$\mathrm{Na}$ Introdução ao tema, um de seus esclarecimentos iniciais "é sobre a focalização no artesanato, na manufatura e na indústria em detrimento da agricultura, do comércio e dos serviços" e sobre sua "orientação metodológica na pesquisa histórico-sociológica". Cunha (2000a) justifica essa opção pela relevância que aqueles setores foram assumindo ao longo do tempo, comparados aos demais setores da economia (p. 4, grifos nossos).

$\mathrm{Na}$ apresentação da coleção, podemos ler: "A presente série de livros pretende sistematizar a produção conceitual - teórica e de reconstrução histórica metodológica e técnica, elaborada e/ou utilizada "nos estudos realizados pela Sede Acadêmica Brasil da FLACSO (Faculdade Latino-Americana de Ciências Sociais (ibid., p. ix, grifo nosso).

O autor é parcimonioso nas referências teóricas ao longo do texto, sem deixar de fazer análise crítica. Sua base teórica está implícita na construção do relato sobre os temas abordados. Alguns autores reconhecidos estão presentes na escrita e outros nas referências bibliográficas ${ }^{2}$. Sua pesquisa histórico-sociológica está ancorada em tempos, espaços e sujeitos sociais bem determinados, em um contexto de transformações políticas, econômicas e culturais, incluídas as educacionais. $\mathrm{O}$ autor atende, assim, a algumas exigências básicas dos trabalhos historiográficos ${ }^{3}$.

De nosso ponto de vista, estes são aspectos fundamentais da historicidade na análise dos fenômenos sociais. Além da contextualização dos acontecimentos abordados e de sua localização no espaço-tempo da época, categorias e conceitos vão surgindo e sendo explicitados através dos fatos apresentados e suas articulações econômicas, políticas e sociais: trabalho manual, trabalho intelectual, trabalho escravo, trabalho livre, força de trabalho, ofícios, além das categorias que colocam em foco o trabalho e a educação: educação artesanal, educação manufatureira, educação industrial, ensino, educação profissional.

O autor aponta ainda o "espaço vazio" da história da educação profissional ${ }^{4}$. Isto poderia ser explicado pelo fato de que "os historiadores da educação brasileira se preocupam, principalmente, com o ensino que se destina às elites políticas e ao trabalho intelectual, deixando o trabalho manual em segundo plano" . Ele vê como um sinal de transformação "a preocupação nos meios acadêmicos pela articulação entre os 'mundos' do trabalho e da educação onde prevalece o viés do 'chão da fábrica"' (CUNHA, 2001 a, p. 1-2).

\footnotetext{
${ }^{2}$ Além de muitos historiadores e sociólogos, constam das referências Marx, (1975), Prado Júnior, (1963), Schaff (1978), Schwarcz, (1973), Smith (1983).

${ }^{3}$ Não necessariamente, todas as categorias da reconstrução histórica têm base no referencial marxista.

${ }^{4}$ Também já apontamos esta lacuna na história de educação em nossos trabalhos, a exemplo de Ciavatta (2015).

${ }^{5}$ Apontamos a mesma lacuna na história de educação, em nossos trabalhos, a exemplo de Cia vatta (2015).
} 


\section{Tempo e espaço: categorias fundamentais da historicidade}

A história é a ciência do ser humano no espaço-tempo de sua vida e da memória que é preservada sobre os acontecimentos vividos, sobre as ideias e os sentimentos que moveram as ações e produziram a existência humana, tal como ela é relatada pelos historiadores. "O espaço e o tempo são categorias básicas da existência humana” (HARVEY, 1992, p, 187).

Os conceitos de espaço e de tempo têm sofrido as transformações decorrentes das concepções que emergem da vida social, científica e cultural. Geógrafos e historiadores têm dado uma contribuição significativa para a compreensão dos acontecimentos localizados na particularidade do espaço social da produção da existência pelo trabalho e nas diversas temporalidades (CIAVATTA, 2007) onde se situam os relatos históricos.

$\mathrm{Na}$ escrita da história do trabalho e da educação, Cunha (op. cit.) não se detém em apresentar os elementos teóricos que nos ocupa nesta seção. Mas é importante explicitá-los aqui porque são conceitos que sustentam a historicidade de seu trabalho. Ele escreve sobre um tempo e um espaço social que dão significado e compreensão aos acontecimentos e aos sujeitos sociais, no contexto das transformações socioeconômicas e políticas que moldaram o trabalho e a sociedade dos tempos coloniais, do Império e do início da República no Brasil.

Próximo ou distante, o passado tem sempre um sentido para nós, sentido que é dado pelo registro da história que nos é contada. Ela nos ajuda a compreender o mundo em que vivemos no presente ou a aceitar as justificativas que legitimam a ordem social estabelecida.

O historiador Jörn Rüsen (2009) nos ajuda a compreender a historicidade da pesquisa nas ciências humanas e sociais e em educação, e a imperiosa relação com a questão do tempo: "A memória torna o passado significativo, o mantém vivo e o torna uma parte essencial da orientação cultural da vida presente". A história é uma forma elaborada de memória que vai além dos limites da vida individual. O passado é rememorado em uma unidade de tempo que se abre para o futuro e permite aos sujeitos sociais uma interpretação das mudanças "para ajustar os movimentos temporais de suas próprias vidas" (p.164).

Os estudos históricos nos revelam que, tradicionalmente, a história era a sucessão linear dos acontecimentos no tempo, a história teleológica, sensível ao conhecimento especulativo e à influência metafísica sobre o conhecimento. A história tradicional registrou a vida humana dando protagonismo aos heróis, aos poderosos, aos grandes feitos

As ciências sociais vão submeter a sociedade à representação do tempo da física, da matemática, buscando regularidades, estabilidades, reversibilidades, homogeneidade, quantidades, permanência. São vertentes diferentes da concepção de história de Marx que eleva todos os atos da vida humana ao nível do acontecimento. A história é a produção social da existência (MARX; 
EN, 1979). Esta é sua concepção inovadora de história, tão bem apropriada por muitos historiadores que incorporaram novas abordagens, novos temas, novos objetos, os grandes acontecimentos e os fatos do cotidiano ${ }^{6}$.

Assumir a história como produção social da existência, é entendê-la como processo real da vida humana e como método de pesquisa ao nível da representação pelo pensamento, pela escrita da história. A historicidade dos fenômenos envolve diferentes temporalidades ${ }^{7}$, tanto em relação ao tema de estudo, quanto às questões teórico-metodológicas e ao espaço-tempo em que ocorrem os acontecimentos tratados.

Compreender presença do passado no presente implica uma concepção de tempo-espaço em que os acontecimentos são vistos, não como um tempo linear, matemático, mas no próprio movimento da história da vida humana., como faz Braudel (1982). O autor concebe a duração social como tempos múltiplos e contraditórios que não pertencem somente ao passado, mas também ao presente, em uma contínua oposição entre o instante e o tempo que nos parece lento, prolongado.

$\mathrm{Na}$ tentativa de criticar a forma de escrever história que trata somente do tempo limitado dos eventos, como a história tradicional, Braudel propõe a diferenciação de três ritmos: um do tempo individual, um do tempo social e um do tempo geográfico, também expressos como a breve duração dos acontecimentos, a média duração das conjunturas e a longa duração da geopolítica, dos longos processos que estruturam as sociedades.

\section{A reconstrução histórica e algumas de suas categorias}

Luiz Antônio Cunha não se ocupa de tratar teoricamente a questão do tempo, mas seu trabalho de pesquisa articula os acontecimentos e seus sujeitos sociais nas múltiplas temporalidades dos séculos de escravidão, das conjunturas da história da sociedade brasileira e das iniciativas individuais e institucionais que marcaram cada período histórico do ensino de ofícios artesanais e manufatureiros no Brasil

Ressalva a escolha metodológica da pesquisa, ao não abordar a agricultura, o comércio e os serviços. Apesar de ser a base forte da economia na época, a educação agrícola não chegou a influenciar a educação profissional tal como a rede de Escolas de Aprendizes Artífices, criada pelo Presidente Nilo Peçanha em $1909^{8}$.

Outra questão teórica presente, mas não explicitada em referenciais teóricos é o contexto social onde os sujeitos agem e ocorrem os acontecimen-

\footnotetext{
${ }^{6}$ Referimo-nos, especialmente, à École des Annales e seus desdobramentos em diversas tendências de interpretação e de escrita da história (v. entre outros, Burke, 1991).

${ }^{7}$ Desenvolvemos o conceito de temporalidade em Ciavatta (2007), tendo por base a concepção dos tempos múltiplos de Braudel (1982)

${ }^{8}$ Decreto n. 7366 de 23 de setembro de 1909.
} 
tos. Nos relatos sobre o Brasil escravocrata, são muitos os sujeitos sociais que fazem a história do país e de suas vidas. São os africanos escravizados que ganham visibilidade nas contradições das relações com seus proprietários, donos dos engenhos, fazendas, áreas de mineração, senhores poderosos na política e na economia.

Depois da Lei da Abolição, como libertos, são vistos como ignorantes, sem qualificação para a indústria nascente, "classes perigosas", prontas a se rebelar. Seus filhos e todas as crianças que perambulam pelas ruas, os órfãos e abandonados são "desvalidos da sorte" que devem ser amparados e regenerados os de maus costumes. E havia a elite intelectual do Império que se inspirava nos intelectuais europeus.

O contexto do ensino de ofícios artesanais e manufatureiros está presente na aprendizagem desses ofícios no Brasil Colônia e no Reino Unido de Portugal com o Brasil, da Metrópole com a Colônia e suas formas de exploração econômica e de educação; nas mudanças na força de trabalho, nas instituições criadas e em suas matrizes ideológicas

As matrizes ideológicas norteadoras dos primórdios da nação brasileira estavam ancoradas no pensamento de diversos intelectuais do século XVIII, tais como: Voltaire, Adam Smith, Jean-Baptiste Say, Robert Malthus, François Guizot (p. 146-148). Cada um destes intelectuais, a seu próprio modo, pregava a manutenção da ordem social através da educação do povo para o trabalho.

No Brasil, o autor cita uma série de intelectuais que contribuíram para disseminação da ideologia que pressupunha uma educação para o trabalho: José Bonifácio, Hipólito da Costa, Pinto de Almeida, Gonçalves Dias, Frederico Burlamaqui, Liberato Barroso, Martin Francisco, João Barbalho Uchoa Cavalcanti, João Alfredo Correa de Oliveira, Felix Ferreira, Leôncio de Carvalho, Joaquim Nabuco, Rui Barbosa, Tarquínio de Souza Filho, José Ricardo Pires de Almeida (ibid., p. 149-177).

Outra consideração de ordem teórica diz respeito aos conceitos e categorias utilizados na reconstrução histórica, e que para nós são fundamentais para a compreensão da desvalorização histórica da educação profissional no Brasil herdada da sociedade escravocrata. Embora nos trabalhos filosóficos e científicos, ambos os termos, categorias e conceitos são utilizados como sinônimos, os dois termos guardam diferenças etimológicas e de apropriação intelectual dos objetos dentro do universo a que se referem.

No nosso entendimento, de preferência, as categorias classificam (de acordo com sua etimologia), ordenam os seres, a exemplo de animais vertebrados e invertebrados etc. Mas servem também às ciências sociais, quando falamos nas classes, de extratos sociais, a exemplo de classes pobres ou ricas, classes altas, médias etc. No caso dos conceitos, por sua etimologia (concepção), eles dão conteúdo teórico aos termos que denominam ou classificam os 
seres e seus atributos, a exemplo de ideologia, contradição, valor etc. (CIAVATTA, 2016; 2016a).

Cunha não se detém em teorizar sobre conceitos e categorias. Mas o tratamento dos fatos, fenômenos ou dados de sua pesquisa são densos de historicidade. No texto, a narrativa segue uma ordem cronológica. Não temos a pretensão de esgotar todas as categorias e conceitos. Nossa escolha foi pautada por aquelas que são centrais para compreendermos a descrição analítica dos temas pelo autor.

Cunha expõe o escravismo presente nas relações sociais, econômicas e políticas e discute as razões do aviltamento do trabalho manual. Aborda a aprendizagem de ofícios artesanais e manufatureiros no Brasil Colônia, destacando o aprendizado de ofícios nos engenhos, nos colégios, na mineração, nas ribeiras e o legado que este período deixou para a educação. Em seguida apresenta as mudanças na força de trabalho com a abolição, a questão do branqueamento do trabalho e a convivência de trabalhadores escravizados e trabalhadores livres nas manufaturas. O ensino de ofícios no Brasil Império e suas principais instituições de ensino também são objeto de análise do autor. Discorre sobre as matrizes ideológicas e o pensamento dos intelectuais da época que influenciaram a educação profissional no Brasil.

Para este trabalho selecionamos as principais categorias analíticas, densamente descritas pelo autor, organizadas por nós em ordem temática, São elas: a herança do escravismo no presente; escravos, libertos e o aviltamento do trabalho manual; a organização do trabalho e o ensino de ofícios artesanais e manufatureiros; o trabalho e a educação para o trabalho.

\subsection{A herança do escravismo no presente}

Uma das principais contribuições do autor para a compreensão do legado escravista na educação do presente é sua reflexão sobre a depreciação histórica do trabalho manual no Brasil, após 1888. Ainda hoje, presenciamos, no Brasil, a desvalorização econômica e social (baixos salários e menor status) dos trabalhadores manuais, profissionais e técnicos. O autor propicia a aproximação entre a história da escravidão e a permanência da dualidade da educação no Brasil, o ensino de nível médio e superior das elites econômicas e intelectuais, e o ensino primário e profissional para a grande maioria da população (CUNHA, 1998).

No passado secular, estudado pelo autor, as marcas das relações escravistas de produção acabaram por afastar a força de trabalho livre do artesanato e da manufatura. Os homens brancos e livres se negavam a aceitar este tipo de trabalho para se diferenciarem da condição de escravo. Gerou-se no país uma estrutura de classes diferenciadas economicamente e por discriminação ideológica étnica e cultural. 
Os estudos sobre o mundo do trabalho e a educação e a história das políticas educacionais ${ }^{9}$ em curso, evidenciam a permanência das diferenças de classe e o preconceito contra o trabalho manual. O longo processo de escravização, como base econômica e como fundamento das relações sociais, alicerçou a ideologia do preconceito na vida pública e privada, nos espaços de convivência e nas relações familiares.

A leitura de Cunha (2001a entre outros) e o conhecimento da história de nosso país evidenciam que, através dos séculos de colonização, de geração em geração, buscou-se consolidar o poder patriarcal das oligarquias latifundiárias e empresariais no mundo político e no padrão de vida da população. Gerou-se grande desigualdade de acesso aos bens econômicos e sociais, inclusive à educação diferenciada para diferentes classes de cidadãos brasileiros.

A análise de Luiz Antônio Cunha sobre o desvalor do trabalho manual nos instiga ainda a refletir, a partir dos debates suscitados pela recente produção acadêmica, sobre a historiografia do trabalho no Brasil, que vem desde a década de 1980, propondo novas formas de interpretação sobre o trabalho escravo e as relações sociais engendradas. A visão do escravizado como um ser coisificado, subjugado por seu senhor, incapaz de protagonizar sua própria história, pensar e agir por si e para si, dá lugar a sujeitos que redefinem significados culturais e políticos, que se manifestam através de diferentes percepções sobre liberdade e sobre a conjuntura política e social em que estavam inseridos.

As revoltas e organizações quilombolas, talvez sejam as formas mais imediatamente reconhecidas como mecanismos de luta e de resistência da população escravizada até o século XIX. Uma das mais difundidas e conhecidas é a Revolta dos Malês, ocorrida em 1835, em Salvador, Bahia (REIS, 1986) ${ }^{10}$. Mas houve muitas outras formas de resistência e protagonismo na história através de estratégias utilizadas no cotidiano da sociedade escravista. Chalhoub e Silva (2009) chamam a atenção para a forma como os trabalhadores escravizados souberam utilizar em proveito próprio as contradições presentes no Estado Imperial, lutando por seus direitos através dos mesmos mecanismos e instituições que garantiam a continuidade da hegemonia da classe senhorial:

[...] a legislação escravista da segunda metade do século XIX abriu brechas para que escravos obtivessem a liberdade por via judicial à revelia da vontade senhorial. [...] esse tipo de aproximação concebe o Estado escravista não como sujeito unívoco e demiurgo da nação, mas vazado

\footnotetext{
${ }^{9}$ Esta reflexão tem por base Ciavatta, 1998 e 2016

${ }^{10}$ A Revolta dos Malês foi um levante de africanos escravizados muçulmanos de língua iorubá, conhecidos como nagôs na Bahia. Foi um movimento político que tinha como um dos principais objetivos a tomada do governo da capital.
} 
por contradições que permitem a escravos e libertos lutar por objetivos próprios e conquistar direitos" (p.24).

Da mesma forma, Silvia Lara (1989) enfatiza os diferentes modelos de exploração do trabalho escravo que não estavam limitados somente ao trabalho nas fazendas no meio rural. A escravidão nas cidades assumia outros modos, como, por exemplo, os chamados escravos de ganho, que trabalhavam para seus senhores, ou eram alugados para terceiros, executando atividades e recebendo uma remuneração que, ao fim de um período determinado (fim do dia, da semana ou do mês), deveria ser entregue ao senhor.

A distância física entre senhores/feitores e seus escravos, permitia o exercício de escolhas e ações individuais que fugiam à rede de vigilância e controle a que os escravizados estavam submetidos. Por outro lado, a complexidade das relações sociais entre senhores e escravos, permeadas por paternalismos e apadrinhamentos, envolvia e controlava os cativos, mostrando ser um mecanismo de dominação bastante eficiente, evitando que estes quebrassem seus elos com as residências senhoriais.

Lara (1989) cita ainda a interferência e participação dos escravos em seus próprios processos de compra e venda que ocorriam nas negociações subsequentes ao tráfico, barganhando do mesmo modo suas condições de trabalho e de sobrevivência.

\begin{abstract}
Muitos se recusavam a ser vendidos: manifestavam desagrado pelo novo senhor [...], procuravam padrinhos que os protegessem ou mesmo que os comprassem; fugiam quando a venda estivesse acertada; ou praticavam ações mais violentas que os levassem às malhas da justiça, tornando assim o negócio impraticável” (LARA, 1989, p.9).
\end{abstract}

\title{
3.2. Escravos, libertos e o aviltamento do trabalho manual
}

A sociologia histórica de Luiz Antonio Cunha apresenta as raízes da formação da classe trabalhadora brasileira e as instituições responsáveis por sua formação, do tempo do escravismo às primeiras décadas da República. Deixa explícita a preocupação das elites com os escravos, depois com os libertos e seus filhos, sob a alegação de manter a "ordem social". O autor expõe diversas iniciativas, desde o século XVIII, de caráter filantrópico, do poder público e da Igreja, que estimulavam o recolhimento das crianças pobres e órfãs, os denominados "desvalidos da sorte"

Uma das questões que o autor destaca, e que era o principal problema para as classes dominantes, na segunda metade do século XIX, era como fazer trabalhar quem já não era mais escravo. A Constituição de 1823, em seu artigo

\footnotetext{
${ }^{11}$ Os "desvalidos" é uma categoria recorrente nos escritos de outros autores analisados por esta pesquisa: Faria Filho (2001), Fonseca (1986); Oliveira (2003).
} 
255, determinava o trabalho compulsório como um meio de corrigir vadios, dissolutos e criminosos. Da mesma forma, o Código Criminal do Império no Brasil de 1830, estabelecia penalidades severas para vadiagem e mendicância. (CUNHA, 2000 a. p. 89)

Chalhoub (1990) traz uma interessante discussão sobre o conceito de "classes perigosas" que aparece de forma implícita na obra de Luiz Antonio Cunha. O termo parece ter surgido na primeira metade do século XIX presente no pensamento de ideólogos que estudavam criminalidade e infância. Mary Carpenter, escritora inglesa, em 1840, definia classes perigosas como "constituídas por pessoas que já haviam passado pela prisão, ou as que, mesmo não tendo sido presas, haviam optado por obter o seu sustento e o de sua família, por meio da prática de furtos e não do trabalho" (CARPENTER, 1840 apud Chalhoub, 1990, p. 5). Cita ainda outro autor europeu, desta vez francês, M.A. Frégier, alto funcionário da polícia de Paris que, no mesmo período, escreveu um livro sobre as "classes perigosas" nas grandes cidades.

No Brasil, o termo passa a ser um dos eixos importantes nos debates parlamentares que ocorreram nos anos pós-abolição. A principal preocupação era com as consequências da libertação dos escravos para a organização do trabalho. Cunha analisa:

A despeito da sobrevivência na legislação brasileira, até recentemente, da possibilidade da prisão por vadiagem, os intelectuais foram cada vez mais se ajustando às práticas vigentes no mercado de trabalho, que substituía a coação pela necessidade material, mediada pela motivação interiorizada via educação (id., p. 182).

Carpenter e Frégier foram apropriados pelos parlamentares da época, encarregados de formular leis sobre o trabalho, ociosidade e criminalidade no Brasil. O resultado dos trabalhos da Comissão Parlamentar revela a ideologização e criminalização daqueles que não se adaptavam às novas regras impos tas para o trabalho livre: todos eram suspeitos de algo até que se provasse o contrário.

Neste contexto, os negros libertos tornaram-se suspeitos preferenciais, pois seus "defeitos" são atribuídos à sua própria "natureza". (Chalhoub, 1990, p. 8). O racismo aqui já mostrava seus efeitos sórdidos.

Nesta perspectiva Luiz Antonio Cunha traz uma outra discussão fundamental para compreensão do aviltamento do trabalho manual: a tentativa de branqueamento do trabalho com o estímulo da vinda de imigrantes europeus para o trabalho nas lavouras.

Negro e Gomes (2006), propõe a superação de uma dicotomia na escrita da história sobre o tema do no Brasil através de abordagens que contemplem a experiência do trabalho escravo com outras formas de trabalho compulsório, livre e assalariado. Para isso, os autores afirmam a premência de um reexame sobre o papel dos africanos escravizados e libertos na formação da 
classe trabalhadora brasileira, mais comumente estudada a partir da chegada dos imigrantes europeus nas lavouras de café.

Tanto Negro e Gomes (2006) como Mattos (2009), apontam para a coexistência de trabalhadores escravizados e assalariados no trabalho manufatureiro e pré-industrial no decorrer do século XIX. Esta convivência proporcionou também formas de organização e de luta, agregando valores e expectativas comuns, que influenciaram momentos posteriores do processo de formação da classe trabalhadora no Brasil. (Mattos, 2009).

\subsection{A organização do trabalho e o ensino de ofícios artesanais e manu- fatureiros}

Cunha (id.) esclarece a distinção entre três tipos de atividades produtivas que vão orientar a organização do trabalho e o ensino de ofícios artesanais e manufatureiros e suas instituições: a produção artesanal, a aprendizagem industrial e a educação manufatureira.

$\mathrm{Na}$ produção artesanal não havia uma sistematização dos processos de aprendizado. A relação entre o mestre e o aprendiz se dava de forma direta e pessoal, muitas vezes coabitando o mesmo espaço de moradia. Os instrumentos de trabalho pertenciam ao mestre de ofício. A regulação da aprendizagem era feita através das corporações de ofício, quando havia.

A aprendizagem industrial era sistematizada e regulada. A formação seguia uma padronização com resultados previsíveis e controláveis, voltada para um grande número de jovens. Era desenvolvida em ambientes especializados como escolas e centros de formação. Os pressupostos eram os mesmos da produção fabril, com intensa divisão do trabalho, separação entre concepção, gerência e execução. A propriedade dos instrumentos de trabalho e o local de aprendizagem não pertenciam aos trabalhadores. A finalidade era estabelecer um posto bem delimitado para o trabalhador assalariado.

$\mathrm{Na}$ educação manufatureira, que ocupava uma posição intermediária entre o artesanato e a indústria, os processos educacionais estavam orientados tanto para o trabalho artesanal quanto para o trabalho industrial, ainda que incipiente naquele período histórico. As Escolas de Aprendizes Artífices, criadas em 1909 no governo Nilo Peçanha, são citadas pelo autor como um exemplo de ensino para o trabalho em manufaturas por possuir tanto uma aprendizagem voltada para o artesanato, como para as formas iniciais da indústria.

Ao abordar a aprendizagem de ofícios artesanais e manufatureiros nos tempos da Colônia, o autor expõe as diferentes conotações que este termo previa à época: os oficiais eram os funcionários da burocracia do Estado, ligados à governança, tais como juízes, desembargadores, procuradores, escrivães, tabeliães, tesoureiros, almoxarifes, recebedores, contadores e vereadores das câmaras municipais. 
Os oficiais mecânicos eram os trabalhadores ligados à atividade produtiva: carpinteiros, pedreiros, ferreiros, barbeiros e outros. As diferenças do termo situam-se nos aspectos econômico e político de suas atividades. Os oficiais mecânicos eram ligados diretamente à produção, e constituíam uma classe dominada econômica e politicamente. (id., p.28).

No Brasil, ao contrário do que aconteceu na Europa, não houve uma linearidade entre as distintas formas de organização da produção. Desta forma, o artesanato não originou a manufatura, como também, desta não se originou o industrialismo. A historiografia sobre o trabalho tem demonstrado que na passagem do século XIX para o XX, havia uma coexistência entre estas formas de produção. Foi necessário, no entanto, importar mão de obra qualificada e equipamentos europeus e adaptá-las à realidade brasileira de homens livres oriundos de um regime escravocrata.

Essas três formas de organização do trabalho e seus objetivos de ensino dos ofícios artesanais e manufatureiros estavam ancoradas em instituições que ostentavam finalidades laborais e educativas, mas com finalidades filantrópicas. Cunha apresenta as seguintes instituições: os estabelecimentos militares, as manufaturas estatais e as entidades filantrópicas propriamente, os Liceus de Artes e Ofícios e a Academia de Belas Artes.

(i) Os estabelecimentos militares foram instituições fundamentais para o ensino de ofícios manufatureiros no Brasil Império. Dentre estas o autor cita o Arsenal de Guerra do Rio de Janeiro, criado em 1733, que mesclava objetivos técnicos, econômicos e ideológicos com o atendimento aos desvalidos. Em Mato Grosso havia a coexistência de modalidades distintas de trabalho: como assalariados por contrato, por empreitada, escravos do Estado, escravos alugados de particulares, trabalho compulsório de soldados cumprindo serviço militar e de prisioneiros civis e militares.

O trabalho nos Arsenais implicava uma rotina rigidamente controlada e disciplinada, com a previsão de penas e infrações e práticas religiosas. Em 1857, a Marinha regulamentou o funcionamento de suas Companhias de Aprendizes Menores dos Arsenais da Marinha. Os aprendizes tinham idades entre 7 e 12 anos e deviam ser robustos, órfãos e desvalidos da sorte. Os estabelecimentos militares foram os primeiros a utilizar a mão-de-obra de menores desvalidos para a formação de força de trabalho para seus arsenais (id., p. 111-112):

(ii) As manufaturas estatais foram criadas após a transferência da corte portuguesa para o Brasil em 1808. A mudança operou profundas mudanças econômicas, políticas, ideológicas e culturais no Rio de Janeiro que ganhou uma biblioteca de 60 mil volumes, um teatro, um museu de mineralogia e um jornal. Criou-se a Imprensa Régia que praticava o ensino de ofícios com tipos trazidos de Lisboa.

A população da cidade mais que dobrou em dez anos. A política econômica estava voltada para o incentivo à produção da indústria manufatureira 
privada. No entanto, mesmo com uma série de medidas que previa a isenção de direitos alfandegários, doação de capital financeiro para particulares e reservas de mercado, as manufaturas privadas não alcançaram o desenvolvimento esperado.

Foi necessário a criação de manufaturas estatais e iniciativas de economia mista para o avanço de alguns setores como a produção de pólvora, de ferro e de outros insumos de uso militar e civil de um modo geral. O autor chama a atenção para o fato de que as primeiras iniciativas de ações educacio nais que surgiram a partir do estabelecimento destas manufaturas estavam voltadas para o contexto de guerra.

(iii) As Casas de Educandos Artífices foram criadas entre 1840 a 1865. Foram dez estabelecimentos mantidos exclusivamente pelo Estado, criados por Presidentes das Províncias, através de leis aprovadas nos parlamentos. Tinham a finalidade o atender aos órfãos e "Expostos da Roda" ${ }^{12}$. Eram vistas mais como instituições de caridade e menos como "obra de instrução pública". A disciplina era rigorosa, militar ou paramilitar. A instrução era dada nos arsenais militares ou em oficinas particulares.

O autor destaca o Asilo dos Meninos Desvalidos do Rio de Janeiro, criado por João Alfredo Correia de Oliveira, ministro do Império, como o mais importante destes estabelecimentos. Segundo Cunha, a clientela destas instituições compreendia também, além dos "desgraçados" sociais, os "desgraçados" físicos portadores de necessidades auditivas e visuais. Os filhos de escravos libertos da coroa também tiveram uma escola profissional, a Escola Mista da Imperial Quinta da Boa Vista, criada em 1882.

(iv) Os Liceus de Artes e Ofícios foram criados com o mesmo intuito de amparo aos órfãos para ensinar-lhes uma profissão. Os liceus surgiram em meados do século XIX nas cidades do Rio de Janeiro, Salvador, Recife, São Paulo, Maceió e Ouro Preto.

Funcionando a partir de doações realizadas por suas sociedades mantenedoras, os cursos eram abertos ao público, vedados apenas aos escravizados. O currículo organizava-se em ciências aplicadas e artes. No entanto, por conta da precária estrutura e da falta de oficinas para o ensino profissional, havia uma grande dificuldade em fixar mestres e instrutores.

O autor concorda com a observação de Fonseca (1986) que afirmava que o liceu era só de artes, não de ofícios. Após a Proclamação da República foram criados novos incentivos jurídicos e fiscais que possibilitaram a manutenção dos Liceus, especialmente no Rio de Janeiro e em São Paulo.

\footnotetext{
12 "Em 1726, o Vice-rei Vasco Meneses determinou que todas as crianças "expostas" fossem abrigadas em asilos. A Santa Casa da Misericórdia, no Rio, adotou, então, o sistema da "Roda", utilizado na Europa desde a Idade Média, e que, aqui, atravessou a Colônia, o Império e chegou à República". Disponível em: <http://rio-curioso.blogspot.com/2009/09/roda-dos-expostos.html>. Acesso em: 08 fev. 2019.
} 
(v) A Academia de Belas Artes cujo funcionamento se efetivou em 1855, tinha o objetivo declarado de servir, direta ou indiretamente, ao desenvolvimento das artes e "auxiliar os progressos da indústria nacional". Os alunos eram divididos em dois grupos: os artistas que se dedicavam às belas artes, e os artífices que professavam as artes mecânicas. Estes últimos eram submetidos a um intenso controle pedagógico.

$\mathrm{O}$ autor recorre ao Renascimento que produziu a diferença entre os artífices e os artistas. $\mathrm{O}$ artista era reconhecido pelo trabalho individual e pela genialidade pessoal, além da capacidade de trabalhar em qualquer lugar, independente de uma associação profissional. $\mathrm{O}$ artífice tinha seu trabalho ligado ao anonimato, restrito ao âmbito de uma corporação de ofícios, que constituía, ao mesmo tempo, uma atenuação de seu enfraquecimento diante das novas condições de produção que se anunciavam. (id., p.12)

Cunha trata das distinções ideológicas entre a Academia de Belas Artes e os Liceus: a primeira criada para ser uma escola superior da aristocracia e do talento, a segunda criada para ser uma escola do povo, "útil às inteligências modestas". Observamos que, já nos primórdios, institucionaliza-se a separação entre o ensino superior e o ensino profissional.

\section{4. O trabalho e a educação para o trabalho}

Trazendo a discussão para tempos mais recentes, Cunha destaca uma questão dos intelectuais no período de transição do Império para a República: como fazer os trabalhadores trabalharem? As relações escravistas de produção passaram a ser vistas como empecilho à acumulação de capital. A solução estava em substituir a força de trabalho escravo pelo trabalho livre e educar para o trabalho.

Cunha (id.) trata do aviltamento do trabalho manual e de quem o praticava. Utiliza a categoria "(des)valor do trabalho manual" ${ }^{13}$ no sentido da desvalorização social do trabalho manual. A pesquisa do autor evidencia que o trabalho manual foi, historicamente, desvalorizado e negligenciado por estar associado ao trabalho desempenhado pelos escravos, considerado como algo menor e que, pretensamente, não prevê trabalho intelectual.

Desde o início da colonização no Brasil, uma das principais questões que preocupavam a classe dominante, desde a metade do século XIX, era

\footnotetext{
${ }^{13}$ Entendemos que o autor não faz referência ao conceito de mais-valia (MARX, 1980), que significa a apropriação de um tempo de trabalho não pago ao trabalhador pelo empregador. Este tratamento do termo "(des)valor" é coerente com um tempo histórico em que não prevalecia o regime do contrato de trabalho assalariado, próprio das relações de trabalho do sistema capitalista. Mattos (2010), tratando de escravos e libertos no mesmo período, registra as lutas dos trabalhadores livres para vender sua força de trabalho como assalariados, apoiando as lutas pelo fim da escravidão, que constituíram o início da formação da classe trabalhadora no Brasil (p. 11 e ss.).
} 
como fazer trabalhar quem já não era mais escravo. As relações escravistas de produção afastaram a força de trabalho livre, os homens brancos, do artesanato e da manufatura. Para os trabalhadores, tratava-se de não deixar dúvidas quanto à sua própria condição e tentar eliminar as ambiguidades da classificação social dos escravos, e as condições aviltantes dos processos de trabalho, condicionados às necessidades do capital nos primórdios da acumulação capitalista no Brasil.

Se no Brasil, que se desenvolveu na modernidade, não tivemos as corporações de ofício no seu sentido próprio, herdamos padrões ideológicos de regulamentação do trabalho, dos ofícios e da educação. Cunha, citando Manacorda (1989), comenta: "[...] a cultura de seus protagonistas não passava de "cacos da ideologia das classes dominantes" (p. 187, apud Cunha, id., p. 11), somados a alguns rudimentos de instrução formal na leitura, na escrita e no cálculo (ibid.).

Duas outras distinções ajudam a entender o trabalho e sua organização no período escravista. É a divisão entre as artes liberais e as artes mecânicas. As artes liberais eram reconhecidas como dignas dos homens "livres da necessidade de trabalhar para viver", entre os que sabiam ler e os que não sabiam. (ibid., p.12).

Outra questão recorrente é convivência de escravos e trabalhadores livres nas manufaturas no século XIX. O autor cita os estudos realizados por Eulália Lobo (1971) e Luiz Carlos Soares (1980), que comprovam a coexistência de trabalhadores livres (brancos e não brancos) e escravizados compondo a força de trabalho nas atividades manufatureiras. Os estudos demonstram ainda que a força de trabalho escravizada (alugada ou contratada diretamente) era formalmente assalariada, no entanto, mantinha o pagamento de rendas aos seus senhores. (ibid., p. 100).

Sempre sem teorizar sobre conceitos, Cunha desdobra seu estudo trazendo ao debate uma série de contradições que cercam a escravidão e o processo progressivo de abolição da escravidão ao longo do século XIX, a exemplo da Lei do Ventre Livre (1871), a Lei dos Sexagenários (1885), poucos anos antes de ser aprovada a Abolição. O branqueamento da força de trabalho é uma das contradições em que se envolveram as classes dominantes.

Dois anos após a independência do Brasil de Portugal, o governo imperial promoveu a imigração de trabalhadores europeus. Uma lei de 1884 criou um imposto anual por escravo que trabalhasse em atividades agrícolas, que deveria ser pago em dobro caso este fosse desviado para outros tipos de trabalho. A receita obtida era revertida para custear a imigração de europeus. $\mathrm{O}$ autor aponta que esta lei era uma tentativa de limitar o emprego de mão-de-obra escravizada na produção agrícola (ibid., p. 96).

Além de representarem uma mão-de-obra com o padrão europeu de cultura do trabalho, os imigrantes contribuíram para a criação das primeiras entidades de trabalhadores no Brasil, familiarizados que já estavam com os pa- 
drões da disciplina industrial em meados do século XIX. Iniciaram formas de organização que acabaram por dar origem aos sindicatos nas primeiras décadas do século XX.

Cunha cita as categorias profissionais dos tipógrafos e dos ferroviários como as pioneiras da organização dos trabalhadores no país, inclusive com as primeiras greves em 1858. O Jornal dos Tipógrafos, criado neste mesmo ano, foi influenciado pelo Manifesto Comunista que havia sido lançado na década anterior (id., p. 94).

Cunha destaca a questão da educação e dos intelectuais no período de transição do Império para a República: como fazer os trabalhadores trabalharem? As relações escravistas de produção passaram a ser vistas como empecilho à acumulação de capital. A solução estava em substituir a força de trabalho escravo pelo trabalho livre e educar para o trabalho.

Colocava-se a questão da aprendizagem compulsória diante do aviltamento do trabalho manual. Algumas ocupações não atraíam pessoas dispostas a desempenhá-las. Em consequência, era necessário ensinar ofícios a crianças e jovens que não tivessem escolha, como os escravos e as crianças abandonadas à Roda, meninos de rua e outros desafortunados (p.23).

As instituições filantrópicas tiveram um importante papel neste período histórico, no que diz respeito à educação profissional dos filhos de pobres ou órfãos. Desde o século XVIII os "desvalidos da sorte" foram objeto de várias iniciativas de educação moral e preparação para o trabalho. O autor destaca a Casa Pia da Bahia, criada em 1804, ainda como colégio da capela de São José do Ribamar, e o Colégio dos Órfãos de São Pedro no Rio de Janeiro, que foi a primeira escola para os "desvalidos", criada em 1739. Posteriormente, transformou-se no Seminário São Joaquim, embrião do Colégio Pedro II.

A Sociedade Auxiliadora da Indústria Nacional foi instalada em 1827. Seu objetivo era de auxiliar a indústria, a agricultura e a pecuária. Também tinha função moralizadora e a instrução ministrada possuía um forte caráter ideológico. Uma curiosidade que o autor destaca é que a escola industrial carecia de alunos. Após dois anos de sua criação a escola continuava vazia.

As razões encontradas pelo autor dizem respeito à vergonha dos adultos de frequentarem a escola e o fato de seus alunos não receberem dispensa do recrutamento para a guarda Nacional, ao contrário do que acontecia nas escolas superiores e nas escolas secundárias públicas. Devido ao insucesso desta iniciativa, posteriormente, o termo indústria foi sendo definido de forma cada vez mais estrita, confundindo-se com a produção manufatureira. Por volta de 1891/1892 a entidade foi fechada por falta de recursos financeiros.

O ensino secundário oferecia formação geral nas ciências e nas humanidades, era restrito e ministrado em poucos estabelecimentos. Destaque para o Seminário São Joaquim, no Rio de Janeiro, que foi a instituição da qual se originou o Colégio Pedro II. De forma paralela, o Estado incentivava um outro tipo de ensino, apartado do ensino secundário, para a formação de uma 
força de trabalho diretamente ligada à produção e ao trabalho manual, os artífices para oficinas, fábricas e arsenais.

\section{Considerações finais}

Trata-se de um trabalho exemplar pelas pesquisas realizadas pelo autor, pela abundância de fontes históricas, pela articulação histórica dos acontecimentos no tempo-espaço em que ocorreram, do século XVI ao século XX. O trabalho de Luiz Antonio Cunha inscreve-se na categorização dialética do tempo de Braudel (1982), que trata dos tempos múltiplos, da longa duração das estruturas, da média duração das conjunturas e do tempo breve dos acontecimentos.

A historicidade da obra se constitui com a contextualização dos fatos, e suas articulações sociais, ideológicas e políticas, assim pelo protagonismo dos sujeitos sociais, individuais e coletivos dos acontecimentos narrados. $\mathrm{O}$ texto contém uma abundância de categorias analisadas no contexto da época em que os fatos ocorreram, e que nos permitem fazer a interlocução com o campo da história da escravidão no Brasil, com o mundo do trabalho e com a educação.

Embora trate da questão do trabalho, principalmente do trabalho escravo, e de relações sociais construídas em torno do trabalho escravo pela sociedade brasileira, Cunha não utiliza explicitamente a análise do capital e da força de trabalho como mercadoria. O "(des)valor do trabalho manual" tem o sentido da desvalorização social e ideológica do trabalho manual. No entanto, estão presentes, em suas referências bibliográficas, O Capital de Marx e obras de historiadores da linha teórica marxista, como A Formação econômica do Brasil contemporâneo de Prado Jr., e História e verdade de Adam Schaff.

A forma como o autor constrói e articula sua narrativa, deixa explícita a questão da dualidade presente historicamente nas políticas de educação profissional no Brasil e que se materializa em uma distribuição desigual da escolarização.

O risco no uso do conceito "dualidade educacional", sem a identificação das particularidades históricas da totalidade do processo, conduz ao abandono da dialética, das mediações e contradições dos fenômenos sociais. O importante são as raízes sociais da questão, a questão estrutural das classes sociais que lhe dão sustentação e sua ideologização como a educação desejável. (CIAVATTA; RAMOS, 2011, p. 29).

As categorias descritas por Cunha tratam das raízes da relação trabalho e educação nos primórdios da formação do país. Elas não esgotam a riqueza dos textos e do detalhamento histórico conduzido pelo autor, mas permitem compreender a herança perversa da sociedade elitista que organizou o trabalho e a educação em condições de desigualdade social e educacional que 
penalizam os trabalhadores e seus filhos até os dias de hoje, na segunda década do século XXI.

Podemos observar que ao lado da especificidade das instituições e dos processos formativos para o trabalho, prevalece o discurso da ordem social, o que nos faz entender que a Educação Profissional no Brasil é moralizante. Seu legado revela o desvalor do trabalho manual, daqueles que o exercem e da educação dos trabalhadores brasileiros. 
B - TRABALHO E EDUCAÇÃO DE CRIANÇAS POBRES 



\section{$\mathbf{V}$ \\ TRABALHO-EDUCAÇÃO DAS CRIANÇAS POBRES NA PRIMEIRA REPÚBLICA - O livro de Luciano Faria Filho ${ }^{*}$}

Rosângela Rosa

\section{Introdução}

A análise em questão refere-se ao livro "República, trabalbo e educação: a experiência do Instituto João Pinheiro 1909/1934", de Luciano Mendes de Faria Filho ${ }^{2}$. O autor investiga de forma minuciosa, a experiência de Leon Renault à frente do Instituto João Pinheiro, na Primeira República, no início do século XX, em Belo Horizonte, Minas Gerais.

Como historiador, o autor publicou e/ou organizou vários livros, tem artigos e capítulos de livros publicados no Brasil, e no exterior, que abordam aspectos do sistema educacional durante a Primeira República.

O livro de Faria estrutura-se a partir de uma introdução e divide-se em sete capítulos, onde o autor discorre sobre a história do instituto e sua organização. $\mathrm{O}$ resultado de seu percurso de pesquisa evidenciou um painel histórico, onde figuram ideais republicanos, que se desenha como um modelo de serviço público para atenção às crianças desamparadas.

O texto, com base nas fontes selecionadas para a pesquisa, o livro cobre quase três décadas da história do Instituto. A experiência educativa/ formadora/ modeladora, embora fosse instituída como "caridade", constituiu-se como ação disciplinadora, sob a ótica da burguesia que a idealizou. Porém tudo não se deu nessa perspectiva, foi necessário aceitar e assimilar, também, experiências de vida, visões do mundo e aspirações dos sujeitos sociais, os educandos do Instituto.

\footnotetext{
*DOI - 10.29388/978-85-53111-86-2-f.99-116

${ }^{1}$ Luciano Mendes de FARIA FILHO. República, trabalbo e educação: a experiência do Instituto João Pinheiro 1909/1934. Bragança Paulista: Editora da Universidade São Francisco, 2001. Este artigo é parte da pesquisa desenvolvida no Projeto CIAVATTA (2012). A pesquisa inicial sobre o livro de Luciano Faria Filho contou com a colaboração de Thaís Fonseca.

${ }^{2}$ Mineiro, nascido em 1964, na cidade de Pocrane, formado em Pedagogia pela Universidade Federal de Minas Gerais (UFMG) (1984-1988), Mestre em Educação (UFMG, 1989-1991). Faria Filho defendeu a dissertação sobre a política de assistência e a educação para meninos pobres em Minas Gerais, no período de 1909 a 1934 que deu origem ao livro. Em 1995 ingressou na Associação Movimento de Educação Popular Paulo Englert (AMEPPE), organização nãogovernamental que trabalha na defesa dos direitos da criança e do adolescente. Doutor em His tória da Educação (USP, 1996). É professor do Programa de Pós-graduação em Educação da UFMG.
} 
Contextualizando seu objeto, Faria Filho apresenta algumas importantes informações sobre a política, a sociedade e a educação ao ser proclamada e instalada a República do Brasil. A leitura nos permite verificar a ênfase na necessidade de formação de um novo cidadão com base na educação, no trabalho e para o trabalho, naquele período. No processo de formação das classes sociais mineiras, o projeto educativo significa uma expressão da formação da burguesia, bem como um momento de formação da classe trabalhadora.

Em nossa análise, o uso de referências teóricas não apropriadas pelo autor, tem o objetivo de ampliar o debate sobre as questões tratadas no livro no campo da historiografia em Trabalho-educação.

\section{As fontes}

A pesquisa historiográfica apresenta questões complexas a serem desveladas. Ao abordar a produção acadêmica de alguns autores, temos a oportunidade de identificar, com um pouco mais de acuidade, a questão do método com que se apresenta o objeto investigado e as escolhas feitas pelo pesquisador para sua análise.

Foi possível identificar pela descrição das fontes, uma quantidade significativa de documentos e, ainda, pelas transcrições e ilustrações utilizadas no livro, um minucioso trabalho de análise documental. Com relação às escolhas, as fontes foram determinantes para o processo de pesquisa. Os documentos de arquivos ou das seções de manuscritos das bibliotecas são considerados fontes primárias. Designamos secundárias, as fontes acessadas por meio de uma outra obra, autor ou pessoa. Michel de Certeau (1982) afirma sobre o estabelecimento das fontes ou da redistribuição do espaço, afirma:

Em história, tudo começa com o gesto de separar, de reunir, de transformar em "documentos" certos objetos distribuídos de outra maneira. Esta nova distribuição cultural é o primeiro trabalho. Na realidade, ela consiste em produzir tais documentos, pelo simples fato de recopiar, transcrever ou fotografar estes objetos mudando ao mesmo tempo o seu lugar e o seu estatuto. [...]" (p. 81).

Faria Filho identifica como suas fontes: o Arquivo Público Mineiro, onde seleciona quatro documentos oficiais do Instituto, sendo um Regulamento da Instituição (1910) e mais três publicações emanadas da Direção do Instituto (1909, 1930 e 1933); documentos da FEBEM (Fundação Estadual do Bem Estar do Menor); arquivos do Instituto João Pinheiro (IJP): prontuários dos ex-alunos; fotografias da instituição; entrevistas com alunos e professores; jornais locais da época e uma vasta bibliografia sobre História e Historiografia, sobre História e Teoria da Educação, elaborados no âmbito de Belo Horizonte, do estado de Minas Gerais e do Brasil. 
A busca na FEBEM resultou no nome de um ex-aluno, João Emério Reges que ingressou no Instituto no período de 1915/1916, tendo permanecido como aluno até 1924, e foi uma fonte importante para o trabalho. Trabalhou, posteriormente como chefe de pavilhão e chegou a Diretor do Instituto na década de 1960. O autor consegue obter acesso a prontuários de ex-alunos, cerca de 4.000. Detalha que os prontuários, analisados mais detidamente, somaram 145, onde se encontravam informações sobre vida dos meninos, anterior e posterior à passagem pelo Instituto. Destaca o conteúdo heterogêneo das pastas com relação à quantidade de documentos averbados, guardados no Arquivo do Setor de Pessoal da Secretaria de Justiça, entre os quais fotografias.

Com base nestas reflexões, analisaremos como o autor trabalha com as fontes que subsidiam sua pesquisa. $\mathrm{O}$ trabalho com as categorias baseou-se nos estudos anteriormente desenvolvidos por Ciavatta: $(2007$; 2012; 2016).

\section{A escrita da história e suas categorias}

Faria Filho descreve de onde fala e sobre suas intenções de pesquisa no Mestrado. Destaca como fonte o livro "Proteção ao menor: Leon Renault um pioneiro", de Delso Renault. ${ }^{3} \mathrm{O}$ autor utiliza, para sua análise, um relatório de pesquisa sobre a organização dos grupos escolares e a formação dos professores da escola pública de primeiro grau de Minas Gerais. O material do relatório remete para os primórdios da legislação mineira e brasileira de proteção à criança e ao adolescente e, mais do que isto, para a própria história de uma experiência concreta de trabalho com crianças abandonadas.

Elabora um projeto de pesquisa sobre o Instituto João Pinheiro, fundado em 1909, para analisar a história de sua organização, proposta educativa, dentre outros aspectos. Para a criação do Instituo é nomeada uma comissão de políticos e de educadores republicanos ligados ao Presidente.

As fontes documentais permitiram uma visão detalhada da organização e da proposta educativa do Instituto durante suas seis primeiras décadas de funcionamento. Desta maneira, a pesquisa ficou delimitada do ano de criação, 1909, até o período final de 25 anos, 1934, período em que Leon Renault esteve à frente da Instituição.

A partir dos prontuários dos ex-alunos, foi possível ao autor analisar algumas dimensões do cotidiano de alunos e de professores do Instituto. Faria Filho concluiu que o Instituto objetivava a formação do trabalhador assalariado e do "cidadão republicano", tendo um pouco de escola e um pouco de prisão, de formação técnica e de formação disciplinar.

\footnotetext{
${ }^{3}$ RENAULT, Delso. Proteção ao menor: Leon Renault um pioneiro. Belo Horizonte: Imprensa Oficial, 1974. Relato sobre o trabalho desenvolvido por Leon Renault, na organização do sistema de proteção à criança e ao adolescente em Minas Gerais e no Brasil, na direção do Instituto João Pinheiro.
} 
A experiência mineira, segundo relata o autor, foi adotada como referência no país, por seu pioneirismo. Outros aspectos que destacamos neste modelo é sua filosofia e a intervenção do Estado na legitimação de políticas de amparo aos menores órfãos e às crianças abandonadas. $\mathrm{O}$ projeto tinha uma matriz prática e teórica, cujo princípio orientador era formar o cidadão que se submetesse ao trabalho, contando, para isso com um sistema público de educação estruturado. Partindo de suas análises nos propomos a identificar quais as categorias nucleares emergem do tratamento teórico e documental dado ao objeto de estudo.

No estudo das categorias presentes no livro, como um todo, percebemos que sua apresentação está substanciada nas inter-relações entre a categoria e o contexto em que se inserem, quando apresentadas. O estudo da teoria, sobre a produção historiográfica dos "historiadores de ofício" e de historiadores da educação brasileira, ajudou-nos a situar o Instituto e a melhor compreender os antecedentes da criação da instituição.

Faria não conceitua ou define suas categorias, mas muitas vezes as ilumina com conceitos encontrados nos documentos de sua análise. As categorias específicas ao tema são: a formação dos meninos; os alunos, os professores, a pobreza, o cotidiano, o trabalhador assalariado, a formação técnica, a formação disciplinar, o "cidadão republicano", a assistência social, as crianças abandonadas, a mão-de-obra, o ensino agrícola, a experiência, o delinquente, a questão social, a resistência. Como historiador da educação, Faria Filho afirma que o Instituto, como instituição eminentemente educativa, era uma instituição penal, tendo acentuado caráter disciplinador e repressivo.

$\mathrm{Na}$ Introdução, o autor trata da base empírica de sua pesquisa, da problemática expressa nas categorias em destaque, sem, contudo, discorrer sobre elas. Emergem do livro as seguintes categorias: criança, adolescente, classes populares, educação, história, trabalho, experiência, professores e ensino agrícola. Ainda na Introdução, no momento em que delineia a organização dos capítulos, destaca, no preâmbulo, as seguintes categorias: povo, formação, educação, formação intelectual.

Faria Filho parte para proposta aventada pela Comissão Fundadora do Instituto que registra orientações para o futuro, defendendo a intervenção do Estado para superação da questão da violência, por meio da atenção às crianças. Os documentos levam em conta a experiência de vários países sobre o tema. Relata que, no Brasil, a assistência social era privada, na forma de filantropia. A intervenção do Estado, tomada como "caridade oficial" poderia contribuir para constituir o cidadão republicano "bem formado", e a solução de um dos grandes problemas da República.

A proposta era dar atenção pública as crianças menores de oito anos, de ambos os sexos, e a meninos maiores de oito anos. Para meninas maiores de oito anos, a opção era a filantropia. A justificativa para isso era a de formação de um novo cidadão, com base na educação e no trabalho. 
A incorporação dos trabalhadores à nação passaria pela formação ideológica dos mesmos, assim o "povo" passaria a identificar a República como algo que pertencesse a ele. Portanto, fazia-se necessária a reforma educacional, tendo com princípio o trabalho como elemento moralizador.

É importante contextualizar o período sobre o qual Faria Filho escreve (1909 / 1934), como novo regime político brasileiro, a República ${ }^{4}$, promulgada em 1889, além de algumas medidas jurídico-políticas, como a recente abolição da escravatura, promulgada em 1888. Trata-se de um período histórico em que o novo se contrapunha ao velho. E este misto de novas perspectivas políticas, ainda atreladas a antigas concepções, interferem em outras dimensões da sociedade, como na cultura e na economia. Revelam-se explícitos abismos de desigualdade social nas relações de trabalho, tornando de extrema relevância a "questão social", a questão da pobreza e da dificuldade entre as classes sociais - o que ocorre até os dias de hoje - como expressa Iamamoto (2007):

Tais desigualdades revelam o descompasso entre temporalidades históricas distintas, mas coetaneamente articuladas, atribuindo particularidades à formação social do País. Afetam a economia, a política e a cultura, redimensionando, simultaneamente, nossa herança histórica e o presente. [...] a modernidade das forças produtivas do trabalho social convive com padrões retrógrados nas relações no trabalho, radicalizando a questão social. (p. 128-129).

O problema social encontrava, na forma de pensar dos políticos, um discurso comum. Defendiam que, para formar um novo cidadão, um indivíduo disciplinado para o trabalho, tal aluno precisava ser formado (ou conformado/modelado) em um sistema público de educação, com estrutura específica e capacidade para tal missão.

Como registramos neste texto, são muitas as categorias analíticas, teórico-empíricas, das quais destacamos as mais recorrentes, a saber: alunos, instituição, trabalho, educação, escola, questão social, resistência.

\subsection{Alunos}

Antes da criação do Instituto João Pinheiro, já tinham sido criadas sociedades civis voltadas ao amparo de crianças órfãs e abandonadas ${ }^{5}$. E a educação profissional no Brasil, inaugurada pela ação do Presidente Nilo Peçanha

\footnotetext{
${ }^{4}$ A maior parte do período histórico brasileiro trabalhado por Faria Filho se refere à Primeira República (1989-1930) e início do Estado getulista (1930-1945).

5 "Um olhar para o passado revela que a questão da infância foi um fenômeno recorrente em contextos de rápida industrialização e desenvolvimento urbano acelerado." (ALVIM; VALADARES, 1988, p. 3).
} 
em 1909 (Decreto n. 7.566/1909), se inicia com caráter assistencialista e com o objetivo de amparar os órfãos e os demais "desvalidos da sorte". Como explicita Faria Filho (2001), falando sobre o Instituto, eram os menores "aban donados material e moralmente", "os órfãos", os "deserdados da sorte", "desvalidos", "desassistidos", as crianças que participavam da clientela dessas instituições, para que tivessem bons costumes. Eram crianças cujas famílias não tinham como proporcionar educação. Foi a partir da correlação de forças políticas e de interesses de classe, que a clientela foi sendo definida.

O autor detém-se na análise da clientela do Instituto, que não era formada por um alunado qualquer. Quem eram os internos? Embora o regimento, defina que somente seriam aceitos pela instituição os menores "abandonados material e moralmente", "os órfãos", "os deserdados da sorte", "os desvalidos", "os desassistidos", outras crianças também participavam da clientela, eram todas crianças pobres educadas para serem trabalhadoras. A relação com a produção se estabelecia no espaço de formação.

A categoria alunos emerge de significativas formas de descrever a clientela, sua faixa etária e perfil dos alunos, a situação familiar, a condição social, as tentativas de superação das condições sociais. Da modelação a resistência, os sujeitos foram sendo apresentados no trabalho de Faria Filho.

A análise destaca outros aspectos, tais como: descrição da estrutura dos pavilhões diferenciados onde os ficavam as crianças, estudo sobre a evolução na capacidade de atendimento dos meninos, estudo sobre o percentual de ingressantes no período de 1909 a 1934, motivos para a internação, situação familiar, profissões exercidas pelos pais, origem e procedência dos meninos, origem geográfica, passado escolar, etc. Pode ser percebido no período, o caráter elitista e de reprodução da estrutura social, claramente definido num modelo estratificado da organização social.

\subsection{A Instituição}

Para Marx (2005), na análise feita na Crítica à Filosofia do Direito de Hegel, as instituições, assim como as ideologias, são partes integrantes das superestruturas, ou seja, do complexo das ideologias religiosas, filosóficas, jurídicas e políticas de determinada classe social dominante numa sociedade. As instituições podem ser definidas como instâncias do saber que permitem a todo tempo a recomposição das relações sociais. Ainda que considerado seu aspecto simbólico, não estão desvinculadas da prática social. Cada sociedade, de acordo com o seu modelo infraestrutural, cria instituições que serão, muitas vezes impostas e mantidas, assim como todas as relações sociais. O Estado, a igreja, a escola, a família, as relações de trabalho, entre outros, serão permeados por instituições das mais diversas ordens e relações de poder.

A concepção, implantação e implementação do Instituto João Pinheiro alimentam a categoria instituição, no que se refere a esta pesquisa. A criação 
do Instituto foi baseada em outras experiências, e podemos dizer que tais experiências foram sendo ajustadas, de acordo com os interesses da elite republicana e com a necessidade de formação da classe trabalhadora.

O Regulamento do Instituto justificava os motivos pelos quais o Estado deveria agir para resolver o problema dos "menores abandonados". Faria Filho analisa os argumentos da Comissão Fundadora para apreender qual o significado da criação da Instituição. Destacou a importância de Leon Renault, por seu protagonismo à frente da instituição e por sua participação na comissão encarregada da instalação do Instituto João Pinheiro. Segundo Faria Filho (2001),

A primeira das razões pelas quais os fundadores defendem a intervenção do estado na resolução do problema das crianças abandonadas, seja esta intervenção entendida como 'caridade oficial' ou dever mesmo do Estado enquanto instituição social, é que uma política para essa área poderia contribuir para a resolução de um dos grandes problemas da República, na perspectiva de alguns republicanos: a ausência de um cidadão republicano ‘bem’ formado (p. 17).

O autor identifica, no que foi expresso pelos republicanos que estavam à frente da Comissão, que a assistência à criança abandonada seria uma intervenção para a construção da Nova República e uma forma de prevenção criminal, uma vez que, para eles, "o abandono de crianças leva à marginalidade". Para tal intento, acreditavam que as ações do Estado e as ações filantrópicas deveriam se equivaler. A necessidade de formar mão de obra traduzia um dos mais sérios problemas enfrentados pela economia mineira naquela época, faltavam braços para a lavoura, e também havia a necessidade de repressão à vadiagem. Essas foram causas apontadas para justificar a criação da instituição.

\subsection{O trabalho}

As modalidades de trabalho praticadas pelo Instituto e a organização dos estudos foram os temas dos capítulos quarto e o quinto, que recuperaram a forma como os ideais republicanos se fizeram presentes naquela instituição. Faria Filho apresenta o que seria o elemento mais importante para os responsáveis pelo Instituto: o trabalho.

Sua prática e seu significado diferem bastante dos conceitos de trabalho e educação como princípios educativos entre os autores que com base em Marx, sustentam a crítica às contradições entre o capital e o trabalho, ao assalariamento e às diferenças de classe entre o trabalhador e o empregador que é dono dos meios de produção.

A categoria trabalho emerge da de um conjunto de fatores intrinsecamente relacionados. Para melhor compreensão da categoria recorremos a Gramsci (2006) que esclarece serem a vida e o trabalho, os elementos consti- 
tuintes da escola unitária. A formação escolar, construção da escola unitária proporcionaria o início de novas relações entre trabalho intelectual e trabalho industrial, modificando as relações sociais não somente na escola, mas, sobretudo na vida social.

O advento da escola unitária significa o início de novas relações entre trabalho intelectual e trabalho industrial não apenas na escola, mas em toda a vida social. O princípio unitário, por isso, irá se refletir em todos os organismos de cultura, transformando-os e emprestando-lhes um novo conteúdo (p. 40).

A teoria de Gramsci aponta para uma direção transformadora capaz de orientar a prática dos educadores, de desvelar a função política da educação e as relações de poder que visam perpetuar as contradições geradas pela sociedade. Os aspectos do trabalho como princípio educativo em Gramsci constituem um importante subsídio para compreensão da formação para o trabalho, nos diversos períodos históricos. Sobre o trabalho como princípio educativo, Gramsci afirma:

O conceito e o fato do trabalho (da atividade teórico-prática) é o princípio educativo imanente à escola elementar, já que a ordem social e estatal (direitos e deveres) é introduzida e identificada na ordem natural pelo trabalho (GRAMSCI, 2006, p. 43).

Gaudêncio Frigotto (2006) quando discorre sobre os projetos societários em disputa, reflete sobre a categoria trabalho e as bases técnico- científicas da produção, no modo de produção capitalista. Em sua análise mostra que o trabalho não se reduz à economia e ao desenvolvimento, considerando a educação como variável interveniente, que deve ser alcançada no sentido ético-político de formação humana. Parte da especificidade do capitalismo que foi tomando forma no Brasil, e da análise das dificuldades objetivas e subjetivas da afirmação da

[...] concepção e da prática da educação escolar omnilateral e politécnica, bem como dos processos massivos de qualificação (científico-técnicas) do trabalhador que superem a lógica do adestramento [...] (p. .242).

Sobre o trabalho, Faria Filho esclarece como o Instituo João Pinheiro se organizava, quais eram seus objetivos e as características que o trabalho deveria assumir. Eram quatro as modalidades em que se organizavam os trabalhos dos alunos no Instituto: manual, agrícola, oficinas e internos:

1. O trabalho Manual, que consistia numa preparação ao trabalho na oficina e ao qual o menor deveria se submeter durante os dois primeiros anos de permanência no Instituto. 
2. O trabalho Agrícola, responsável pela formação de trabalhadores agrícolas e pela produção de gêneros alimentícios para a própria instituição.

3. O trabalho nas Oficinas, pensado como complemento do trabalho agrícola na formação dos agricultores, formador de competências artesanais e também destinados a produzir roupas, caixas e outros utensílios para o Instituto e o para o mercado de Belo Horizonte.

4. O trabalho Interno, em cada pavilhão, uma vez que os educadores eram responsáveis pela limpeza/higiene do mesmo, pelos cuidados com o jardim, por alguma criação doméstica (galinha, porco, etc.) e pela escrituração (p. 87-88).

Ressalta, porém, que uma parte do trabalho era realizada também por educadores. Exceto cozinhar e o trabalho de escrituração, todo o restante era feito pelos próprios alunos. De acordo com o artigo $11^{\circ}$ do Regulamente do IJP "aos menores ficará incumbido o asseio do prédio e dependências; a eles caberão igualmente o serviço da copa, do auxílio na cozinha, da jardinagem, horticultura e pomicultura, de lavagem e conserto da roupa" (REGULAMENTO, 1910, p. 30 apud FARIA FILHO, 2001, p.99).

Além das especificidades de cada modalidade do trabalho, que capacitava as crianças tecnicamente, o Instituto direcionava o trabalho diretamente à formação de costumes, de hábitos e de valores morais. O principal valor do trabalho difundido entre as crianças era o valor do trabalho na vida humana. Era muito comum, mesmo entre os alunos, o discurso de que o trabalho enobrece, dignifica, os afasta do ócio e dos vícios, que apenas é digno de viver em sociedade aquele que trabalha, e sem o trabalho é impossível viver. A formação, a que o Instituto se destinava a oferecer, não era apenas uma formação profissional, era também moral e ideológica.

Entre as quatro modalidades de trabalho, a que mais chama a atenção, é a do trabalho interno porque era o que orientava a formação dos alunos, aprender fazendo de acordo com as normas do Instituto. É possível observar que o trabalho interno tinha um objetivo muito singular: o castigo. Além de ser uma tarefa que não atribuía remuneração aos alunos, o trabalho interno era encarado como "muito modesto" diante das outras modalidades "mais dignas".

A ênfase da formação, notadamente, preparava para o trabalho agrícola, lembrando, como já mencionado, que o programa se voltava às necessidades específicas da economia mineira. Mas o que era gerado pelas crianças beneficiava também a instituição; parte dos ganhos era para custear sua manutenção, e os alunos eram remunerados de acordo com sua produção.

O documento, "Experiências e perspectivas sobre Escolas de Produção no meio urbano no Brasil", ' pode auxiliar na compreensão das experiências de Escolas de

${ }^{6}$ CENAFOR. Experiências e perspectivas sobre Escolas de Produção no meio urbano no Brasil. Relatório Final. São Paulo, CENAFOR, 1982. 
Produção no Brasil. Sobretudo auxilia a explorar aspectos da relação educação/trabalho, pois nestas escolas assim como no Instituto, os alunos trabalhavam para custear, em parte, seus estudos.

As chamadas escolas de produção, nos anos 1970, reproduziam tais práticas. Surgiram como uma das alternativas de operacionalização da relação trabalho-educação-renda, buscando estreitar as relações entre trabalho e educação. A proposta pretendia combinar o ensino com o trabalho produtivo. Assim as escolas do sistema formal de educação passariam a desenvolver projetos produtivos onde os alunos, aprendendo a produzir, gerariam renda.

Com relação à formação para o trabalho no Instituto João Pinheiro, ressaltamos que o trabalho da escola burguesa é o trabalho sob as relações capitalistas de produção. Nessa perspectiva de formação, jovens e crianças são educados sob os princípios do trabalho alienado, explorado, desigual e desumanizante. Podemos dizer que o trabalho como princípio educativo também orienta a concepção burguesa de educação. Mas, em uma visão dialética da realidade, o caráter formativo e emancipador ou alienante do trabalho depende das condições de vida e das relações de trabalho dos trabalhadores, e de sua capacidade organizativa para ter acesso ao conhecimento e a condições dignas de vida.

Tais análises nos instigam, como Ciavatta (2009), a buscar "compreender como a relação trabalho e educação ganha forma e significado nas escolas que preparam pequenos e jovens trabalhadores para o trabalho, no contexto das relações sociais capitalistas e do desenvolvimento das forças produtivas". (p. 37).

\subsection{A "educação"}

Também para a análise da categoria educação iniciamos recuperando o pensamento de Gramsci (1978) como um contraponto à educação dos alunos do Instituto. Consideramos a educação como espaço de formação do sujeito social, Uma ideia só se realiza plenamente se é apoderada pelo movimento social concreto e se transforma em ação prática. Gramsci defendia a importância da escola, entendendo-a em sua função educativa que permeia toda a estrutura social.

Segundo quando Gramsci, nenhum projeto de transformação social cumprirá seu objetivo se não vier acoplado a uma profunda reforma intelectual e moral. Neste processo está em jogo "[...] a concepção de um 'bloco histórico' em que precisamente as forças materiais são o conteúdo e as ideologias a forma, [...] porque as forças materiais não seriam concebíveis historicamente sem forma e as ideologias seriam caprichos individuais sem as forças materiais" (id., p. 66)

Faria Filho aborda a categoria educação a partir da organização dos estudos no Instituto João Pinheiro. Destaca que o Instituto organizou um cur- 
so primário de oito períodos, cada período com a duração de um ano. No ano de 1909, de acordo com o autor, os alunos foram divididos em duas turmas, cada uma em um turno.

A ênfase na formação, notadamente, preparava para o trabalho agrícola e para as necessidades específicas da economia mineira. Constituía-se em um curso primário, composto por oito períodos com duração de um ano cada, cujo "objetivo era propiciar aos alunos o ensino da leitura, da escrita, do cálculo e os ensinamentos teóricos básicos para o trabalho na agricultura" (FARIA FILHO, 2001, p. 107).

As aulas eram ministradas de $6 \mathrm{~h} 30 \mathrm{~min}$ às 9 horas da manhã e das 18 horas às $20 \mathrm{~h} 30 \mathrm{~min}$ da noite. A carga horária diária de aulas era de apenas duas horas e meia a três horas. Há uma lacuna de informação direta sobre as atividades no intervalo entre os dois turnos de aula, o matinal e o noturno. Mas é importante a observação do autor que a carga horária diária destinada à formação intelectual das crianças era inferior à carga horária destinada ao trabalho nas oficinas ou na lavoura. Além de que, "Mais de uma vez, L. Renault e os visitantes chamam a atenção para o fato de que, dadas as necessidades da lavoura, muitas vezes a "escola foi sacrificada" (idem, p. 107).

A educação era para o trabalho, acontecia na forma de produção, era aprender fazendo, realizando a formação no trabalho. Parte desse trabalho se revertia em remuneração, dentro do cotidiano do IJP. Constituía-se de dois modos: uma oportunidade de ganho e um mecanismo de formação. Aprender a ser um trabalhador assalariado não se resumia apenas na função econômica, mas também na função moralizante comportamental de cada aluno.

E a noção de dinheiro? Cada aluno da "João Pinheiro" aprende, a saber, o que o dinheiro vale. A vadiação é multada. A malcriação é paga em dinheiro. $\mathrm{O}$ mau procedimento é dinheiro perdido. Cada aluno ganha um tanto. $\mathrm{O}$ que fizer de mal lhe diminui a renda: a que embolsa, a que lhe fica para pecúlio. A cada fato social corresponde uma certa situação econômica. (Alberto Deodato, 1926. In: Assistência, 1930, p.85 apud FARIA FILHO, 2001, p.100).

Os elementos levantados por Faria Filho nos permitem compreender a ênfase do projeto educacional e o movimento da categoria educação. As intenções ideológicas, hegemônicas e modeladoras se expressavam na forma de educar, preparar os alunos do Instituto para a vida e para o trabalho.

\subsection{A escola}

A categoria escola aparece de forma recorrente nos capítulos do livro de Faria Filho, o que mostra sua força como categoria teórica no contexto de nosso estudo. As escolas "estão diretamente direcionadas para a formação, nas crianças, de valores, hábitos, atitudes e de capacidades técnicas àqueles que de- 
verão viver do próprio trabalho", como observa Faria Filho (2001, p. 88). A escola em questão é uma escola modeladora e cumpriu um importante papel no que se refere a sua função social.

Se voltamos a Gramsci (1975), vemos que defendia a importância da escola, entendendo-a em sua função educativa, que permeia a estrutura social e, ainda, como um problema técnico e político ao mesmo tempo, considerando que, no Estado burguês (Estado parlamentar-democrático), "o problema da escola é insolúvel política e tecnicamente: os ministros da Instrução pública são investidos no cargo porque pertencentes a um partido político, não porque capazes de administrar e dirigir a função educativa do Estado" (p. 255). Gramsci pensava em uma escola que atendesse às necessidades da população pobre para dar-lhes meios de elevação social, não para modelá-los a serviço dos proprietários rurais, como no caso do IJP. Esta é uma ambiguidade implícita na instituição escolar.

Segundo Gramsci, o Estado não se reduzia ao aparelho de Estado, mas compreendia algumas das instituições da sociedade civil, como a Igreja, as escolas, os sindicatos. No que se refere às escolas, o autor acreditava que a escola, como outras instituições da sociedade civil, vai cumprir dialeticamente a dupla função estratégica de, por um lado, conservar, ou seja, perpetuar a estruturas de classes e, por outro, a mesma escola poderia minar as estruturas capitalistas.

Para ele a concepção de mundo se manifesta em diferentes níveis, desde o senso comum e o folclore passando pela religião, ideologia, ciência e filosofia. Sua convicção era de que escola tinha extrema importância para os trabalhadores, pois atuaria como um instrumento de preparação de intelectuais dos vários níveis, elevação da formação cultural e intelectual dos grupos sociais.

Retomando o livro de Faria Filho, observamos algumas das motivações da Comissão que fundamentou a necessidade de criação do Instituto,

[...] seria um lugar onde a criança receberia "tratamento" visando sua "regeneração" bem como ao seu afastamento do "meio deletério" representado por seus acompanhantes e pelas ruas das cidades, passando pela localização no campo, a organização em forma de pavilhões "familiares", pela superposição de modelos educativos/formativos [...] (id. p. 131-132).

Faria Filho, no capítulo seis do seu livro, "Fontes inspiradoras: escola nova ou escola-prisão?", destaca as fontes que inspiraram a criação do Instituto João Pinheiro. Resgata a concepção dos fundadores na definição do modelo escolar e avança apontando a defesa do tipo de educação ofertada pelo IJP por parte dos republicanos mineiros da época. Os fundadores defendiam a intervenção do Estado na resolução do problema das crianças abandonadas. Visando cumprir esse objetivo, a Comissão Fundadora inspirou-se em experiên- 
cias conhecidas e teve sua concepção nas ideias de Enrico Ferri, outros autores europeus e João Pinheiro que os recomendava.

$\mathrm{O}$ autor esclarece, pontualmente, os ícones da época que inspiraram a concepção do Instituto, tais como, Enrico Ferri (1856 - 1929), criminalista italiano, considerado um expoente da Escola positivista, que avaliava o crime como uma doença social; Mettray, uma escola agrícola francesa com organização idêntica ao Instituto, fundada em 1839 por M. Metz (1797-1873), magistrado e filósofo francês, que inspirou-se numa experiência alemã, a colônia Rauhe-Haus, situada em Hamburgo, que atendia a crianças viciadas, pervertidas ou ameaçadas de perversão.

Outra experiência citada é École des Roches, fundada na França, em 1899, por Edmond Demolins, apresentava uma proposta pedagógica e organizacional inspirada no ideário escolanovista, destinada exclusivamente às elites, com forte ênfase na formação intelectual, encarava o trabalho manual como um passatempo útil.

Alguns desses processos são utilizados com crianças pobres no sentido de prevenção aos maus costumes e ao crime, de regeneração e de disciplinamento. Faria Filho cita alguns exemplos que inspiraram a do IJP, quanto à "participação dos educandos na vida escolar, a intenção de não impor castigos corporais às crianças, o "jornal escolar", a localização no campo" (FARIA FILHO, 2001. p. 120-131). O IJP surgiu nesse contexto, como escola modeladora que ensinaria o "novo cidadão republicano" a se comportar, "seguindo o figurino da classe dirigente, na República, no trabalho e no lar" (id., p. 137).

Outro elemento que aparece como subsídio das análises de Faria Filho parte da observação de fotografias da época, em que Faria Filho dedica vários parágrafos à dissertação etnográfica sobre a apresentação física das salas de aulas, a posição dos alunos e dos professores. Entre outros aspectos, o autor destaca a falta de conforto, as condições precárias das carteiras e a falta de material pedagógico decorativo como ausência de estímulo visual, mostrando que a imagem histórico-fotográfica pode revelar o significado do discurso sobre a realidade da escola (p. 108-109).

Faria Filho finaliza este capítulo afirmando que as experiências do IJP deveriam ser encaradas não apenas a partir de uma perspectiva pedagógica, mas "uma intervenção política" na formação de

[...] uma sociedade republicana. onde a organização disciplinar, a vivência moral, enfim, todas as relações, podem ser controladas e, mais que isto, com base nesta vivência pretendem-se propor reformas à sociedade "de verdade" com o intuito de resolver seus "problemas "sociais como a luta de classes, a pobreza e a existência de "classes perigosas". [...] valendo-se dos mais "modernos" referenciais liberais,

\footnotetext{
${ }^{7} \mathrm{O}$ "jornal escolar" circulava dentro do IJP, com a importante participação dos alunos.
} 
incorporar os trabalhadores cidadãos ao trabalho assalariado e à República, sob o controle e domínio da classe dirigente (p. 133-134).

\subsection{A questão social}

A expressão "questão social" surgiu na terceira década do século XIX (CASTEL, 1998: 30). Para entender seu significado e seu uso no livro, consideramos a trajetória da expressão "questão social" nas obras de Marx e Engels. Tal abordagem permite-nos compreender como a expressão ganhou um status de categoria teórica. Depois dos anos 1830, com o afervorar das lutas de classe entre proprietários e não-proprietários, Marx e Engels renunciaram à expressão e passaram a referir-se aos problemas sociais sob a ótica classista dos trabalhadores.

A expressão teria emergido no cenário europeu, quando as múltiplas expressões da "questão social" tornaram-se um problema a ser enfrentado pelas classes dominantes. Seu uso faz-se presente a partir da separação positivista, no pensamento conservador, entre o econômico e o social, dissociado das questões tipicamente econômicas, as "questões sociais" (NETTO, 2001, p. 42). Tal separação surge quando a classe burguesa perdeu seu caráter crítico revolucionário perante as lutas proletárias e surgiu um novo tipo de racionalidade (LUKÁCS, 1992, p. 109). Segundo Lukács, foi a chamada "decadência ideológica da burguesia", assim descrita:

[...] após o surgimento da economia marxista, seria impossível ignorar a luta de classes como fato fundamental do desenvolvimento social, sempre que as relações sociais fossem estudadas a parti da economia. Para fugir dessa necessidade, surgiu a sociologia como ciência autônoma [...] Desta forma, "o nascimento da sociologia como disciplina independente faz com que o tratamento do problema da sociedade deixe de lado a sua base econômica; a suposta independência entre as questões sociais e as questões econômicas constitui o ponto de partida metodológico da sociologia (p. 132).

Muitos críticos sociais utilizaram o termo, para descrever as condições de vida de trabalhadores, submetidos à exploração capitalista no início da era burguesa e, por conseguinte, submetidos a condições miseráveis. O uso indiscriminado da expressão "questão social" acabou por fornecer-lhe diversos conteúdos e atribuições muito diferentes, mas uma coisa é certa: todos eles se referiam ao pauperismo absoluto dos trabalhadores assalariados (NETTO, ibid.).

A partir da análise marxista a que se propõe este trabalho, é possível apontar que, a utilização do termo "classes perigosas", citado por Faria Filho, se refere a uma pobreza que não é encarada como um problema de distribuição de renda, mas como um problema social. Para melhor elucidar este deba- 
te, recorremos ao José Paulo Neto (id., p. 146-149) que aponta a "questão social" como fato engendrado pelo capitalismo. Muito além do que se imagina popularmente quando se destaca a produção capitalista como produção e reprodução da mais-valia e das mercadorias, José Paulo Neto afirma que a produção capitalista é produção e reprodução de relações sociais.

A "questão social" manifesta-se na miséria, na pobreza. Suas causas estavam vinculadas a três tipos de fatores: o primeiro, um déficit educativo; o segundo um problema de planejamento; $e$, por fim, problemas de ordem moral, comportamental. Assim, a questão social não é entendida como uma consequência da exploração econômica, e sim como um conjunto de fenômenos autônomos e de responsabilidade individual ou coletiva das pessoas pobres.

Esta concepção de pobreza, típica da Europa, dos séculos XVI a XIX, teve forte influência na organização de ações filantrópicas. Surgem, desta forma, os abrigos para "pobres" e as organizações de caridade e filantropia, como o IJP. O objetivo dessas instituições era alterar os aspectos morais do indivíduo, com seu papel moralizador, Segundo Netto, considerando a pobreza e as manifestações da "questão social" como um problema que se expressa em comportamentos, a solução seria alterar tais comportamentos por meio da educação (NETTO, 2001).

Paulatinamente, a compreensão do que se entende por "questão social", passa a ser internalizado na ordem social, não como um problema do indivíduo, mas como consequência do desenvolvimento social e econômico. Como adverte Netto, a "questão social" passa de ser um "caso de polícia". É o que Faria Filho descreve fidedignamente, quando relata o disciplinamento no Instituto e as necessidades de formar um cidadão republicano.

Para a esfera da política, a questão passa a ser tratada de forma segmentada, mas sistemática, mediante as políticas sociais estatais (id.). Portanto, a oferta de trabalho, destinado aos alunos, pode ser encarada como uma função dentro do IJP, para integrá-los à sociedade por meio de um emprego.

\subsection{A resistência}

A categoria resistência foi selecionada para nossa análise por sua desafiadora significação no contexto de formação do IJP. Ressaltamos que a categoria resistência deve sempre ser analisada em função de um acontecimento histórico datado e localizado no espaço e no tempo. Considerando ainda que a resistência nasce de um processo dialético, pois é produto de contradições, buscaremos contextualizar seu significado no estudo desenvolvido no livro de Faria Filho (id.), tendo como referência da análise outros autores.

O termo resistência, em Michel Foucault, envolve a questão do poder. $\mathrm{O}$ autor enfatiza "o papel do indivíduo e das coletividades nas lutas de transformação das estruturas de poder ora vigentes. Os modos de ser das lutas de 
resistência [...] (BRANCO, 2001, p. 237). Marx trabalha as relações de poder exercidas pelo Estado de acordo com as forças sociais dominantes.

Marx (1979), em seus escritos, afirma que "as ideias dominantes, são as ideias da classe dominante", visto que dispõe dos meios de produção material que se refletem na produção intelectual (p. 72). Mas, os dominados desenvolvem estratégias de resistência, o que gera a consciência do proletariado. Logo a consciência de classe é marcada pela luta de classes, estando a categoria resistência circunscrita à luta de classes.

No ensaio, "Narrativa e Resistência", Bosi (2002) busca uma categorização da resistência. $\mathrm{O}$ autor esclarece que pensar sobre a resistência significa pensar a distinção entre razão e intuição, nas esferas artística e política. Desta forma, a categoria resistência é apresentada pelo autor com os seguintes termos: resistir é opor-se à vontade alheia, posto que a resistência se vincula a uma relação entre valores e antivalores, que se opõem, a exemplo de liberdade e despotismo, igualdade e iniquidade etc.

O pesquisador argentino Federico Lorenz (2012), estudou a elaboração da categoria resistência, pensando, inicialmente, na etimologia do termo, e analisando as condutas militares, como exemplo de força opositiva paradigmática. $\mathrm{O}$ autor enfatiza a importância de um grupo para que haja resistência, afirma que ela não é solitária, pois resistir equivale a contestar algo, e, portanto, um único indivíduo não conseguiria ter chances de sucesso.

No trabalho de Faria Filho, o destino dos egressos foi analisado nas fontes referentes ao tempo de permanência dos meninos, prontuários dos exalunos, motivo alegado para a exclusão dos alunos, profissão exercida pelos alunos, localidade onde trabalham os ex-alunos e contratos de trabalho. Os egressos questionam as intenções da instituição, visto que a mesma estava profundamente ligada aos interesses classistas de seus instituidores, segundo o autor, "um momento do processo de formação da burguesia e classe trabalhadora mineira" (p. 166).

$\mathrm{Na}$ conclusão do seu trabalho dissertativo a respeito do IJP, Faria Filho esclarece que a proposta da instituição na época, de fato, foi algo efetivamente bastante singular. A intencionalidade da instituição estava visceralmente ligada aos interesses classistas de quem a organizou. Ele destaca que os objetivos que o Instituto perseguia eram claros e definidos: "[...] formar um trabalhador capacitado, técnica, ética e disciplinarmente para o mercado de trabalho assalariado; mas também um cidadão ordeiro e respeitador da lei e da autoridade" (id., p.163-164).

De acordo com o autor, o sucesso da instituição era evidente a partir de duas perspectivas: a criação de outras instituições similares, dando continuidade ao trabalho iniciado na IJP; e também pela influência de Leon Renault na legislação mineira quando se tratava de assistência pública às crianças oriundas das camadas populares. 
Faria Filho atenta ao fato de que, muito provavelmente, a Comissão fundadora do IJP não imaginou que a instituição, inicialmente voltada apenas para as crianças abandonadas, se estenderia também às crianças tuteladas por seus responsáveis, devido à falta de escolas públicas, ou mesmo pela dificuldade que muitas famílias tinham em criar seus filhos.

$\mathrm{O}$ autor ensaia sobre a possibilidade de problematizar a questão da resistência dos alunos dentro do Instituto. Afinal, a educação não reproduz, somente. No entanto, não elabora esta hipótese, justamente, por ter identificado nos prontuários dos ex-alunos inúmeros elogios positivos sobre o "internamento". Porém, ele destaca como resistência o fato dos ex-alunos recusarem massivamente o trabalho agrícola. É possível afirmar, a partir da leitura do autor, que, na época de sua vida no Instituto, os ex-alunos, na tentativa de traçarem seus destinos no mundo do trabalho, subverteram, a seu favor, as práticas rígidas de controle e a vigilância por parte do Instituto, ao resistirem ao trabalho no meio rural.

Neste ponto, finalizando a sua exposição, Faria Filho tangencia o uso da categoria contradição, ainda que não a apresente literalmente. Ao questionarem o cumprimento do contrato trabalhista, a submissão do seu tempo livre para o trabalho, as práticas que permeiam o salário, entre outros aspectos que os levam a recusa massiva do trabalho agrícola, os ex-alunos do IJP se colocam em situação de conflito e luta com os interesses ideológicos daqueles que criaram a instituição. Em longo prazo, se constrói uma cultura de luta, resistência e participação ativa "da classe trabalhadora mineira" (id. p.165-166). Faria Filho possibilita um percurso pelos indícios da presença dos movimentos de resistência nas relações de poder instituídas no espaço de formação do Instituto João Pinheiro.

\section{Considerações finais}

No trabalho desenvolvido no livro "República, trabalbo e educação: a experiência do Instituto João Pinheiro 1909/1934", de Luciano Mendes de Faria Filho, o autor investiga de forma minuciosa a experiência de Leon Renault à frente do Instituto João Pinheiro, na Primeira República, A obra constitui-se em um precioso trabalho de investigação de fontes na busca de escrever a história da experiência do Instituto.

Sua pesquisa historiográfica cuidadosa descreve o contexto da criação do Instituto e cobre quase três décadas da história em meio a ricas citações de documentos da época, à explicitação da conjuntura política e do projeto pensado para a formação da classe trabalhadora. Ademais, quando se refere aos alunos, lhes confere o movimento de sujeitos sociais que ofereciam resistência à conformação pretendida, à experiência modeladora, pensada para educação dos "pobres" e instituída como "caridade". 
São muitas as categorias encontradas no texto. Faria não conceitua ou define suas categorias, mas muitas vezes as ilumina com conceitos encontrados nos documentos de sua análise. As categorias recorrentes referem-se a sujeitos sociais (alunos, educadores, trabalhadores, crianças, abandonados, menores), a trabalho (agrícola, assalariado, social, industrial, intelectual, capitalista, manual), à formação (educação, escola, repressão, disciplina, cidadão republicano), a relações sociais (assistência social, filantropia patronato, questão social, resistência)

Para nosso estudo selecionamos as categorias teórico-empíricas que, na apreciação, mas se destacaram: alunos, instituição, trabalho, educação, escol, questão social e resistência, por suas possibilidades de adensar nossas reflexões sobre a história e a historiografia de trabalho-educação. A investigação sobre a escrita da obra e suas categorias de análise serviram como uma relevante contribuição para o objetivo principal do projeto de Pesquisa do qual é parte, como se escreve a história da educação profissional no Brasil. 


\title{
VI \\ O PROTAGONISMO DOS PRETOS E PARDOS NA LUTA POR ESCOLA NA PRIMEIRA METADE DO SÉCULO XIX - O livro de Adriana Maria Paulo da Silva ${ }^{*_{1}}$
}

\author{
Jacqueline Botelho \\ Mônica Rocha
}

\section{Introdução}

O presente artigo é resultado do estudo da obra da historiadora Adriana Maria Paulo da Silva "Aprender Com Perfeição e sem Coação: uma escola para meninos pretos e pardos na Corte", que muito tem a contribuir para a análise do percurso histórico das políticas educacionais brasileiras, especialmente àquela direcionada ao ensino das primeiras letras iniciado no Brasil, no século XIX. No Mestrado em Educação, na Universidade Federal Fluminense (19971999), a autora desenvolveu seus estudos explorando a documentação relativa às iniciativas governamentais e, também, às experiências privadas da educação no século XIX ${ }^{2}$.

Pretendemos, no presente artigo, destacar as categorias presentes no livro, e que vieram revestidas de um referencial teórico-metodológico ancorado na teoria crítica $^{3}$, o que permitiu uma percepção da realidade histórica vivenciada pelos escravos africanos classificados como pretos $^{4}$, bem como dos crioulos e pardos, num cenário que demonstra a movimentação política e ideoló-

\footnotetext{
${ }^{*}$ DOI - 10.29388/978-85-53111-86-2-f.117-130

${ }^{1}$ SILVA, Adriana Maria Paulo da. Aprender Com Perfeição e sem Coação: Uma escola para meninos pretos e pardos na Corte. Série passado/presente v.1, Brasília: Editora Plano, 2000. Este artigo é parte da pesquisa desenvolvida no Projeto CIAVATTA (2012),

${ }^{2}$ A Professora Adriana Maria Paulo da Silva fez seu Doutorado em História pela Universidade Federal de Pernambuco no período de 2002-2006. Atualmente é professora Adjunta da Universidade Federal de Pernambuco e professora do Curso de Pós-graduação em Educação. Lidera o Grupo de Pesquisa "História da Educação e das práticas de educabilidade no mundo iberoamericano" e atua no ensino e pesquisa, com ênfase em história social da educação, história so cial do trabalho docente e historiografia do ensino de história.

${ }^{3}$ A autora não se detém em explicitar sua concepção da teoria crítica, mas cita, na introdução ao texto, José Baía Horta e Hebe Castro e, nas referências bibliográficas, muitos historiadores, entre os quais, Carlo Ginzburg, Robert Danton, Sidney Chalhoub, Alfredo Bosi, Mário Manacorda, Florestan Fernandes.

${ }^{4}$ Pretos (escravos africanos) crioulos (escravos brasileiros) e pardos (homens ou mulheres de cor preta ou mestiços que estavam livres). Não utilizaremos aqui a expressão negro, mais utilizada por alguns movimentos sociais na atualidade, pois esta não foi a expressão utilizada na época analisada pela autora.
} 
gica da classe conservadora, os chamados Saquaremas ${ }^{5}$, no uso da instrução e do ensino, como forma de garantir a manutenção do status quo numa sociedade escravista sob o regime monárquico ${ }^{6}$.

O objeto inicial de Silva (2000) é o acesso à escola e a permanência de crianças pobres neste espaço. Através de uma pesquisa de grande fôlego no Arquivo Nacional do Rio de Janeiro, a autora foi às fontes primárias na busca de compreender os múltiplos porquês que justificavam a autorização concedida pelo Inspetor Eusébio de Queirós para que Pretextato dos Passos e Silva, autodeclarado como homem preto, pudesse lecionar para meninos/as pretos/ as e pardos/as, num cenário ainda escravista. Pretextato foi o protagonista de uma história onde se mostrou como um educador com veia militante ao denunciar o racismo nas escolas e declarar a possibilidade dos discípulos aprenderem com perfeição, sem coação, ao ter um homem preto como mestre. A escola de Pretextato funcionou aproximadamente vinte anos, na Rua da Alfândega, 313, local que era também a residência do professor.

\section{O livro e sua historicidade}

O livro de Silva (2000) conta com um prefácio do Professor Osmar Fávero, que sinaliza a "adequação do instrumental teórico-metodológico" e a descoberta pela autora de caminhos a serem explorados num autêntico trabalho de pesquisa histórica. (Idem, p. 9).

Em sua primeira incursão, Silva (idem) busca nos arquivos das Conferências da Glória, datados dos anos 70 do século XIX, documentos sobre a instrução pública e a Lei da Obrigatoriedade de 1854. Nos documentos das Conferências aparecia o "desleixo" das famílias pobres, como justificativa oficial para a ausência de crianças pretas e pardas nas escolas. A historiadora desconstrói esta afirmação ao longo de sua pesquisa e, buscando vestígios da época, encontra vozes silenciadas nas fontes, que foram ocultadas nos arquivos oficiais. A autora indaga aos documentos o que não estava dito, questionando também o dito "desleixo".

Com um texto de instigante leitura, Silva (idem) relata que "começou a mexer nos documentos buscando as pistas" nos ofícios referentes a Inspeção Municipal, já que, desde 1834, através de Ato Adicional, era incumbência dos municípios fazer o controle das escolas. Em suas pesquisas Silva (idem) encontrou um ofício, datado de 1856, do então inspetor-geral da instrução primária e secundária da Corte, Eusébio de Queirós, ao Ministro do Império

\footnotetext{
${ }^{5}$ Mais sobre os Saquaremas pode ser encontrado em MATTOS, Ilmar Rohloff de. O tempo saquarema. A formação do estado imperial. $2^{a}$ edição, São Paulo, Hucitec, 1990.

${ }^{6}$ Não utilizaremos aqui a expressão negro, mais utilizada pelo movimento negro na atualidade, pois esta não fora a expressão utilizada na época analisada pela autora do livro.

7 Silva destaca "desleixo" ou "desleixados" sempre entre aspas; nós também decidimos mantêlas.
} 
Couto Ferraz, pedindo o funcionamento de uma "escola destinada para meninos de cor". Também curioso à pesquisadora era o fato de o ofício pedir isenção de algumas exigências ao professor requerente, o professor Pretextato dos Passos Silva, criando, assim, concessões ao funcionamento da escola. Eusébio de Queirós omitiu a cor de Pretextato, e, também, as outras características de sua vida privada (estado civil, profissão e endereço anterior) na documentação que era exigida para autorizar o funcionamento da sua escola, e a autora busca investigar os motivos para esta omissão.

Em sua pesquisa, Silva (idem) relata experiências em pleno período de escravidão negra no Brasil. As escolas públicas de ensino das primeiras letras, naquela época, eram proibidas para os pretos. A autora dialoga com o leitor, que é provocado pelo texto a pensar novas respostas à concessão de Eusébio de Queirós ao funcionamento da escola de Pretextato. Considerando o lugar de classe de Eusébio de Queirós e o contexto de desumanização vivenciado por pretos e pardos naquela sociedade de base escravista, percebemos que, certamente, haveria interesse em ocultar o protagonismo de um homem preto, para que não servisse como referência para os demais, numa conjuntura de escravismo tardio (MOURA, 1988), e reação dos escravizados no Brasil, guardadas as particularidades regionais.

Silva (idem) preocupa-se em mostrar como a formação dos pretos esteve confinada ao espaço privado, e desconstrói a hipótese de que havia "desleixo" dos pais em não colocarem seus filhos na escola ao demonstrar que a escola não estava acessível a todos, e que o Professor Pretextato reivindicou a escola como única alternativa para as crianças pretas e pardas aprenderem sem discriminação. O livro é composto de quatro capítulos, que situam o papel social esperado da escola pelos pretos e pardos, para garantirem o distanciamento da condição escrava.

No primeiro capítulo, ganha destaque a dominação colonial na América Portuguesa que, a partir das análises da autora, revela um cotidiano de submissão. Porém, na contradição, era possibilitada uma mobilidade da população preta e parda no período, que tinha como base a busca pelo afastamento da experiência da escravidão e de suas marcas, bem como, em algumas situações, o exercício de ofícios nas cidades, possibilitado pelo aluguel de escravos, sem que fossem arrefecidas as marcas da escravidão. (MOURA, 1988)

Silva demonstra como os autores utilizados trataram suas fontes. Mattos (1990), Villela (1990), Alves (1992), Castro (1995), Cardoso (1987 e 1988), Chalhoub (1990), Góes (1999), Slenes (1989), Silva e Reis (1989), Carvalho (1998), Faria (1990) Wissenbach (1998) foram pesquisadores de característica documental, um traço próprio da historiografia clássica ou tradicional.

Ao fazer a revisão bibliográfica, a autora buscou informações completas sobre os sujeitos da época, incluindo informações como "cor" e "escolarização" dos requerentes por espaços escolares, demonstrando isto, quando diz: 
Naqueles documentos constam informações sobre os mais variados assuntos que vão de alforrias a divórcio, incluindo pessoas de todas as categorias sociais, cor e sexo, e permitem, portando, uma aproximação satisfatória à sociedade da época. (SILVA, 2000 p.25).

Com base no trabalho de Mattos (1990), destaca a formação do Estado Imperial, levado à frente pela classe senhorial, também em formação neste mesmo processo. "O trabalho que era compulsório, viveu o extremo na América Portuguesa", diz a autora. A partir de Novais (1998), Silva (idem) situa a metamorfose do regional em nacional para além dos antagonismos de classe. Para a autora, a nossa emergência na história possui relação com o estudo da privacidade e do cotidiano, tomado como manifestações, articuladas com as demais esferas da experiência humana. As esferas do público e privado se confundiam em vários momentos, no contexto estudado pela autora.

A legislação que regulamentava a educação vai outorgar ao Estado o controle sobre o trabalho dos professores:

Assim, pelo Decreto de 1816, o Desembargador do Paço foi encarregado de controlar os estudos e escolas, além de controlar as nomeações de professores. E o Decreto de 1821 centralizou, mais ainda, tal controle na figura de José da Silva Lisboa, unicamente encarregado desta função, acrescentando à sua responsabilidade o Museu e "outros estabelecimentos científicos" que D. João não tivesse posto a cargo de ninguém em especial. Não foi vã a mudança do título do cargo de "Diretor" para "Inspetor", na variação dos termos transparece a preocupação com a vigilância constante daquele ramo da administração". (ibid., p.39-40 grifos nossos)

Assim, controle e vigilância à educação aparecem como controle dos espaços públicos e privados, controle das normas, controle do trabalho, da moralidade e da vida cotidiana dos professores. Os professores, para exercerem o magistério, deveriam atestar sua moral publicamente junto às autoridades. Desta forma, Pretextato precisou reunir assinaturas de vizinhos e autoridades da época para que pudesse lecionar.

O capítulo segundo é denso em números, datas e documentos. A autora começa o capítulo contando o caso do Professor Anacleto Elias de Vargas e Vasconcelos, como requerente de uma cadeira de Instrução Primária na Freguesia de Santiago de Inhaúma. Sobre Anacleto, apenas disse ser possuidor de família, com filhos e conhecedor dos investimentos do Império na educação primária, reconhecendo-se como súdito.

$\mathrm{Na}$ Instrução Primária da época do Império, nas primeiras décadas do século XIX, o Brasil seguiu a orientação de Portugal, e nas Escolas da Corte o Ensino Mútuo foi o método adotado, com o Governo português criando as 
escolas nos espaços dos quartéis ${ }^{8}$. Segundo Silva, a questão ia além da divulgação do método. As escolas eram criadas por decisão do governo, através das Portarias Imperiais que foram anteriores à Primeira Lei da educação no Brasil, de 15 de outubro de 1827. Silva (2000) afirma que:

\begin{abstract}
No projeto original, deveriam ser criadas escolas de ensino mútuo em todas as capitais de províncias. Seriam também criadas nas vilas, cidades e lugares mais populosos que tivessem prédios apropriados ao método. Somente os professores destas últimas localidades, caso não conhecessem o método, deveriam se dirigir às capitais para aprendê-lo por conta própria. (ibid., p. 68)
\end{abstract}

Os espaços escolares também eram espaços que demonstravam hierarquização, considerando que nem todos tinham liberdade para acessá-los, especialmente os escravos e libertos pobres.

Considerando a responsabilidade do Estado com a escola, a autora aborda no texto que "a Constituição de 1824 estipulou a gratuidade do ensino primário, e a Lei de 1827 obrigou o governo apenas a cobrir os gastos materiais das escolas de primeiras letras que instituíssem o ensino mútuo" (ibid., p.81.) Somente os cidadãos ativos tinham direito à escola e ao ensino das primeiras letras. Na lei de 1827 havia uma orientação para que as escolas fossem instaladas em localidades com maior contingente populacional.

A pesquisadora enxerga o "não dito", ao olhar as entrelinhas dos requerimentos que solicitavam as escolas. Ao destacar a frase: "A dura necessidade de existir" (idem, p.81), faz menção à parte do texto de uma carta do Professor Felizardo Joaquim da Silva Moraes, que lecionava em casa alugada na Rua da Alfândega, 84 (era vizinho de Pretextato) por 20 mil réis. A pesquisadora considera, com este destaque, o sentimento daquele professor em relação ao seu ofício. As escolas particulares cresciam mais que as públicas; segundo a pesquisa de Silva eram públicas 6 escolas, com 488 meninos, e particulares 90 escolas, com 2134 meninos e 705 meninas. Eram Anacletos, Felisbertos, Pretextatos e centenas de meninos e meninas povoando a Rua da Alfândega e adjacências, em espaços escolares.

A categoria trabalho aparece em todo capítulo terceiro, que tem como objetivo demonstrar como a formação da classe senhorial exercia o monopólio de terras e homens, e como ela via na educação escolar não um direito, mas um privilégio. Era a oposição senhor/escravo, que atravessando todos os aspectos da vida na Corte, conferia estatuto e significados diferenciados em rela-

\footnotetext{
${ }^{8} \mathrm{O}$ Ensino mútuo surgiu como proposta a partir de iniciativas privadas para educação popular, com o Pastor Anglicano Andrew Bell (1753-1812) e o Quaker Joseph Lancaster (1778-1838). O Método Lancasteriano era baseado no ensino mútuo (Silva não entra nos detalhes do método). Cita o livro "O Ensino Mútuo" do alemão José Hamel, traduzido para o italiano em 1819. Para Hamel o ensino mútuo era: sintético, econômico, uma instrução elementar e oportuno. Era “uma instrução para as classes inferiores da sociedade.” (SILVA, 2000, p. 65).
} 
ção às condições de trabalho. Segundo Silva, isto não provocava questionamento, e era visto como "natural" e autoexplicativo, repercutindo nas demais relações, incidindo inclusive sobre os não escravizados.

As estratégias alternativas estavam contidas em "espaços de liberdade", e na estrutura de controle das relações escravistas. Os chamados "espaços de liberdade" estavam representados pela mobilidade possível pelo aluguel dos escravizados, pela migração, pela convivência de escravizados e libertos, pretos, pardos e crioulos no espaço urbano, eventualmente com acesso às primeiras letras, sem que se tornasse possível o apagamento da opressão, do preconceito e do racismo.

Existiam escravos que trabalhavam "a ganho", era uma espécie de terceirização de mão-de-obra escrava, que oferecia um trabalho especializado.:

Na realidade urbana da Corte, da primeira metade do século XIX, os escravos, majoritariamente africanos, estavam presentes em todos os tipos de atividades: domésticas, comerciais, artesanais, industriais, nos serviços urbanos, construção civil, limpeza urbana, calçamento das ruas, carregamento de água para residências e estabelecimentos comerciais/industriais, iluminação, correios, encanamentos de rios, e nos transportes de gente e mercadorias, como estivadores, carregadores de leiteria, remadores e marinheiros. Exerciam também o ofício de cirurgiões barbeiros, os quais eram encarregados de cuidar dos cabelos e barbas de quem procurasse - incluindo população escrava. Outros, ainda, exerciam profissões artísticas, eram entalhadores, santeiros, ourives, armeiros, pintores, escultores, músicos e dançarinos (ALGRANTI, 1980, p. 73-95, apud. SILVA, idem, p. 103-104).

Para aqueles que trabalhavam no meio urbano saber ler, escrever e contar potencializava o valor do trabalho.

Aprendizagem de jardineiro, cocheiro ou cozinheiro, além de ler, escrever e contar e cozer oferecem-se aos negros ou negras de 8 a 10 anos numa organização da Rua Direita (atual Primeiro de Março) (ALGRANTI, 1980, p.90, apud SILVA, idem, p. 105).

A instrução ou especialização era oferecida para crianças, conforme o texto citado, e tinha como foco a preparação para trabalhos domésticos, e também a manutenção de determinados lugares sociais. Os trabalhadores na Corte eram muito jovens. Segundo Adriana "A imagem é fortíssima!" Exclama: "Podemos visualizar a capital da Corte Imperial, do ponto de vista de seus trabalhadores, como uma cidade de meninos". (SILVA, 2000, p.106).

A autora demonstra como caminhos alternativos foram trilhados, e ao contar a história, explicita como novas pesquisas buscaram dar voz para aqueles que foram silenciados. Para a autora a construção da "liberdade" girou em torno da propriedade, mesmo que não fosse de si mesmo, mas sim de algumas 
coisas, como roupas, pertences pessoais, mobilidade para transitar do local de moradia para o local de trabalho. Interessante também é destacar, que para Silva, existia uma segmentação do mercado de trabalho e uma disputa entre brancos pobres e escravos, transformando os conflitos em questões de classe.

No capítulo quatro, a experiência do Professor Pretextato é contada, considerando a hipótese desta experiência ser apenas mais uma, entre várias outras possíveis à época.

Silva aponta a influência da pesquisa da Professora Hebe de Castro (1995) em seu trabalho. Para Castro, a mobilidade estava associada à liberdade, e mover-se territorialmente só era possível ao não escravo. Na perspectiva da pesquisa de Castro, os livres "viviam sobre si" e os não livres "serviam a", e "viver sobre si" é "mover-se". O que Silva quer destacar como relevante para o seu trabalho da pesquisa de Castro, é a mobilidade do Sudeste escravista na primeira metade do século XIX, considerando a propriedade da terra e a propriedade de escravos.

$\mathrm{Na}$ sociedade escravista brasileira do século XIX a experiência de liberdade estava associada ao não trabalho. Contudo, era trabalhando que os escravos se moviam. Estudar ou frequentar um espaço escolar significava lutar pela mobilidade, sendo escravo ou não.

Ainda fazendo menção ao trabalho de Castro (1995), a autora destaca que todos os livres eram mencionados nos documentos como brancos ou pardos. Pardo, segundo Castro, era a designação da "condição mais geral do não branco". E crioulo e preto para forros recentes e escravos. Sendo crioulo o escravo brasileiro, e preto o escravo africano. Então, ser pardo não era referência à cor, mas à condição social. A identificação de cor sumiu dos documentos, havia um "silêncio da cor" (Idem, p. 34).

\section{Falando das fontes}

As fontes são como porta de entrada para construir o conhecimento sobre o passado, e esta é parte intrínseca ao ofício dos historiadores e historiadoras, sendo sua apresentação indispensável para a realização deste trabalho (ALVES, 2001; PETERSEN, 2013). As fontes que Silva recorreu foram, a princípio, as "Conferências da Glória", e posteriormente, os "ofícios da instrução". Diante dos documentos, inquiriu os mesmos, e com posição crítica ao observar o que os mesmos ofereciam, questionou se todos os pais seriam ou não "desleixados". Com esse questionamento possibilitou à pesquisa mudar de direção. Ao interrogar o documento, o historiador transforma o objeto em fonte, pois os documentos sozinhos não dizem nada. (PETERSEN, 2013). Silva (2000) interrogou os documentos sobre o "desleixo" dos pais que apareciam como causa do fracasso escolar das crianças.

No início, sua motivação aos arquivos foi observar a origem da obrigatoriedade do ensino. A partir do conhecimento da publicação das chamadas 
"Conferências da Glória" ou "Conferências Populares" (1873-1885), a autora foi se familiarizando com os temas educacionais do debate da época. Silva (idem) levantou uma questão para este período: "Quais os motivos pelos quais a Lei do Ensino Obrigatório de 1854 não vingou?” Com este questionamento, Silva foi a busca dos homens e mulheres que deram origem às relações sociais no período.

A autora foi pesquisar no Arquivo Nacional a documentação sobre a instrução pública e os ofícios trocados entre a Câmara Municipal da Corte e o Ministério do Império. Nesta correspondência tinha uma resposta como causa do não cumprimento da Lei de Obrigatoriedade, que era o "desleixo dos pais". Contudo, o suposto "desleixo dos pais" não convenceu prontamente a pesquisadora, que encontrou nos documentos pesquisados um ofício de Eusébio de Queiros, sobre a escola de Pretextato. Desta forma, Silva questiona as fontes, possibilitando a percepção concreta de dominação das elites, a partir de diferentes mecanismos, que incluem os documentos oficiais utilizados pela autora.

Vimos com isto, que a insatisfação da pesquisadora em relação à justificativa oferecida pelos documentos mudou o curso do projeto original, e, mais do que isto, possibilitou o conhecimento das alternativas educacionais para aquele período.

As fontes de Silva estavam no Arquivo Nacional, local onde buscou os documentos da instrução pública e os ofícios trocados entre a Câmara Municipal da Corte e o Ministério do Império. Documentos datados do período de 1830 à 1854 foram a base para os relatórios ministeriais do Império (documentos das escolas públicas de Primeiras Letras da Corte nas freguesias urbanas e rurais). Com isto, as Conferências da Glória perdem centralidade, agora definida nos relatórios, onde a definição "desleixo" eventualmente aparecia.

As perguntas durante o processo de pesquisa são feitas numa perspectiva, obedecendo uma orientação teórica e institucional, pois toda fala e toda escolha estão "subordinadas" a um determinado lugar. (CARDOSO, 1986; PETERSEN, idem) $\mathrm{Na}$ relação com as fontes, o/a historiador(a) leva em consideração seus interesses e motivações, que possuem uma ligação direta com sua trajetória pessoal, com suas escolhas e também vinculação institucional.

O conhecimento ou saber histórico tem como compromisso, desde sua origem como disciplina isolada, no século XIX, a autenticidade documental, e assim sendo a concepção dominante prevaleceu, pois os dados oficiais são os dados que estão nos arquivos do Estado (JANOT'TI, 2008)

Tanto as autoridades como os professores povoaram os arquivos, nos registros pesquisados por Silva(2000), sendo o arquivo o espaço do escrito, do oficial. Quanto aos pais dos alunos, eram pobres, não apareciam na burocracia cartorial. Silva (idem) indaga quais eram as condições materiais que permitiam àqueles pais agirem supostamente daquela forma, desconfiando dos arquivos oficiais, que os caracterizavam de "desleixados". 
No que diz respeito à mobilidade discente, Silva (idem) afirma que o "desleixo" dos professores aparecia como justificativa. Porém, o motivo da mobilidade discente, não mencionado nos relatórios, era a frequente mudança de endereço das famílias no meio urbano como estratégia para o afastamento das marcas da escravidão e de busca por sobrevivência.

Silva (2000) volta às fontes, aos inquéritos, aos processos. Mas, o registro burocrático é o mundo dos livres. Da mesma forma que pergunta: Quem era Pretextato? Pergunta também: Quem era Eusébio? Com suas inquietações e insatisfações diante do que o documento oferecia como relato oficial, a historiadora constrói sua pesquisa num pensamento crítico, o que permitiu o protagonismo de Pretextato, possibilitando destacar na história o trabalho de um professor preto, reivindicando uma escola para crianças pretas, com uma solicitação de pais pretos, num momento em que ser preto era sinônimo de ser escravo. Com este trabalho histórico, Silva (idem) recupera a voz de Pretextato, localiza sua escola, e comprova, na construção da pesquisa, que os relatos oficiais nem sempre são compatíveis com o cotidiano e a história.

A escola de Pretextato era de iniciativa privada, porque a educação ainda não se configurava como um direito para pretos e pardos. Porém, Pretextato não escondia a cor, ao contrário, ela era tomada como argumento para organizar uma escola destinada especificamente a meninos e meninas pretos e pardos, pois assim, segundo ele, estariam estes livres do "racismo" ou discriminação de outros professores. Antes mesmo de ser um argumento de Pretextato, segundo a historiadora, este também era o argumento usado pelos pais que reivindicaram o funcionamento da escola de Pretextato, que teve seu funcionamento autorizado a pedidos destes, em formato de abaixo assinado anexado ao requerimento de pedido de funcionamento. Ao contar esta história, Silva (idem) também fez um trabalho de historiografia. Desta forma, bibliografia também é fonte. "Quando a pesquisa é sobre historiografia a bibliografia é uma fonte primária" (PETERSEN, 2013, p.303)

\section{A escrita da história e suas categorias}

Cada coisa sobre a qual o homem concentra o seu olhar, a sua atenção, a sua ação ou a sua avaliação, emerge de um determinado todo que a circunda, todo que o homem percebe como um pano de fundo indeterminado, ou uma conexão imaginária, obscuramente intuída. Como o homem percebe os objetos isolados? Como únicos e absolutamente isolados? Ele os percebe sempre no horizonte de um determinado todo, na maioria das vezes, não expresso e não percebido explicitamente. (KOSIK, 1993, p. 31.

O objetivo principal deste artigo é destacar suas contribuições para pensar determinadas categorias na construção da pesquisa histórica sobre o tema proposto. 
$\mathrm{Na}$ intenção de investigarmos as categorias teóricas e categorias específicas ao campo trabalho-educação, utilizadas pela autora nesta obra, buscamos identificar o contexto sócio-histórico narrado pela mesma, e identificar de que forma as categorias que aparecem no texto revelam o referencial teórico metodológico escolhido pela autora.

Durante a pesquisa e a confecção deste artigo, diversas categorias foram identificadas. Porém, para este artigo, selecionamos a apresentação de algumas categorias mais expressivas para concluir a reflexão sobre o livro de Silva (idem). Desta forma, damos destaque às categorias totalidade/particularidade, classe, social, espaço-tempo, trabalho, escolarização.

As categorias servem para ordenar e explicar uma situação histórica, fazendo uma conexão entre passado e presente, o passado da história contada e o presente de quem conta a história. É o referencial teórico-metodológico que permite "selecionar" as categorias que expressam os processos sociais ou mediações históricas que constituem os acontecimentos. A categoria particularidade aparece na relação com a categoria totalidade, considerando a reprodução do concreto real como totalidade concreta pensada. Contudo, o uso da categoria particularidade exige atenção, pois "particularidade não é singularidade", a particularidade é um "campo de mediações", o campo da história. (CIAVATTA, 2007; 2009).

Consideramos que destacar as categorias é mais do que numerá-las, é trazer para discussão suas referências. Dado os limites deste texto, não podemos aprofundar as referências de todas as categorias utilizadas pela autora. Temos, como questão principal, como a história é escrita, tendo o texto de Silva como objeto de estudo.

\subsection{Totalidade/particularidade}

Ao abordar a questão da escola para meninos e meninas, que se classificavam como pretos e pardos, a autora utiliza categorias lançando mão de um referencial teórico que observa a história deste período com base na formação da identidade da sociedade brasileira, que estava sendo forjada. Consideramos que o caso de Pretextato, não é singular, mas particular na totalidade da Corte. Embora, exista na pesquisa de Silva a relação entre a particularidade de Pretextato, sua escola e a totalidade da Corte Imperial do Brasil do século XIX, a categoria particularidade não aparece explicitamente no texto, mas o tratamento histórico do tema permite esta análise.

\subsection{Classe social}

A categoria classe social surge no texto de Mattos (1990; 1991, apud Silva, 2000). A autora toma por base o referencial gramsciano de Mattos. A construção das classes sociais, no Brasil, surge como três classes, a saber: a 
boa sociedade, composta pelos homens brancos proprietários; o povo, homens livres não proprietários; e os escravos, homens e mulheres que eram propriedade de outros homens. Também destaca no texto, que existia uma hierarquização entre os livres, realizada segundo o patrimônio. Eram dois tipos de hierarquização, uma entre cidadãos e não cidadãos, com base na liberdade; e outra entre os cidadãos ativos e os não ativos, também com base no patrimônio. Assim, era um único Império e três mundos, com hierarquizações, incorporações e exclusões intraclasses e extraclasses.

Quanto à classe trabalhadora, a autora não se detém nesta categoria, mas às dimensões culturais e subjetivas do sujeito principal da história no livro, Pretextato, e de seus pares, são relevantes. Fica claro que a classe trabalhadora é uma relação social, historicamente formada, não simplesmente um conceito forjado como resultado das relações de produção, independente dos sujeitos sociais que a constituem.

Trazer tal questão é fundamental e decisivo para o debate contemporâneo. Mattos (2015), assim como Silva(2000), também estudou este período da história brasileira, e diz que a categoria classe trabalhadora, para categorizar os trabalhadores, é uma importação que tem como base uma Europa industrializada, aplicada a um Brasil escravista". Para Thompson, "o processo de formação de classe só pode ser compreendido a partir das condições objetivas que opõem, nas relações de produção, os produtores diretos que, detendo dos meios de produção, exploram os que nada possuem" (MATTOS, 2010, p. 13). Por isso, defende que, para entender classe trabalhadora no Brasil, é necessário estudar como os trabalhadores escravizados e os trabalhadores livres se constituíram classe na resistência às relações de trabalho escravistas, antes e depois da lei da Abolição (Idem, p. 9-14).

\subsection{Escolarização/Escola}

A escolarização surge como um espaço para controlar e instrumentalizar estes sujeitos tão hierarquicamente diferenciados no mundo material, com o acesso à escola também hierarquizado, obedecendo à lógica material dos três diferentes mundos, com escolarização diferenciada para as diferentes classes.

A escola para meninos pretos do Professor Pretextato, traz um conteúdo histórico, que possibilita aberturas para pensar como a categoria trabalho, e sua relação com a educação para grupos subalternos, tinha uma conexão que não era necessariamente a oficial, dominante no Império escravista, na formação de uma população brasileira diferenciada, e com formação desigual.

\footnotetext{
${ }^{9}$ Mattos cita Hobsbawn e Thompson que influenciaram as análises sobre classe trabalhadora no Brasil. MATTOS, Marcelo Badaró. Trabalho, classe trabalhadora e o debate sobre sujeito histórico ontem e hoje. In: NEVES, Renake Bertholdo David (org.) Trabalho, estranhamento e emancipação. Coleção NIEP Marx v. 1, Rio de Janeiro, Consequência, 2015.p.93.
} 


\subsection{Trabalho}

Como já mencionado, a categoria trabalho aparece em todo capítulo terceiro, que tem como objetivo demonstrar como a formação da classe senhorial exercia o monopólio de terras e de homens escravizados no trabalho, e como a mesma via na educação escolar não um direito, mas um privilégio. (SILVA, 2000)

Todo tipo de trabalho na Corte, na primeira metade do século XIX, era exercido por escravos. Segundo Silva (idem), os escravos estavam presentes em todos os lugares da vida social brasileira. A autora, ao discriminar o trabalho na Corte, afirma que existiam três formas de trabalho escravo nesse período: sob o mando, alugados e "ao ganho". Esta diferenciação conferia condições diferentes de trabalho e, também, de movimentação de seus executantes, possibilitando também uma mobilidade, ou até uma flexibilidade da condição escrava.

As relações de trabalho, livres ou compulsórias coexistiam na Corte do século XIX, e as fronteiras entre trabalho escravo e trabalho não escravo eram fluidas. O ambiente urbano da Corte no Rio de Janeiro, com portos e um cotidiano de exportação/importação, possibilitava o compartilhamento de experiências na venda da mão-de-obra, entre trabalhadores escravizados e não escravizados.

Pretextato, o protagonista da história de Silva era identificado como professor, se tinha outras atividades, se era livre ou escravo, não está dito no texto, nem nos documentos que serviram de fontes, mas podemos inferir que tratava-se de um homem livre ou liberto, por não haver registros sobre seus proprietários nos documentos oficiais.

\subsection{Espaço-tempo}

Destacamos também do texto de Silva a categoria espaço-tempo. É um dos traços da historicidade do estudo desenvolvido. Consideramos que a autora constrói seu texto ao pensar sobre o significado que a educação ocupa na Corte Imperial do final do século XIX, e as vozes que são produzidas nestes espaços e sobre estes espaços, naquela temporalidade ${ }^{10}$. Para os professores, a escola era espaço de aprendizado e o magistério um instrumento de atuação política para transformação da realidade. Para Pretextato e para seus alunos, a escola era espaço de afirmação de identidade, em um tempo de escravidão.

\footnotetext{
${ }^{10} \mathrm{~A}$ pesquisa social superou a concepção do tempo de Newton segundo um modelo matemático, como algo fixo, imutável, absoluto. A categoria espaço-tempo tem por base a concepção de tempo como movimento no espaço, e de espaço como uma relação social, e não apenas geo gráfica (HARVEY, 2005; CIAVATTA, 2007).
} 
O acesso à escola foi amplamente controlado, na medida em que ela era tomada como lugar que poderia viabilizar a desobediência, a revolta, e também a insatisfação dos populares. Juntamente com Silva (2000), pudemos compreender a educação institucionalizada na escola, e o papel que a mesma ocupava na Corte Imperial, bem como as vozes que são produzidas, através de uma história protagonizada por Pretextato.

Os espaços de formação escolar eram espaços de manutenção, produção de hierarquias e divisão dos papéis sociais, assim como de divisão de trabalho intelectual e manual, o que fazia a diferenciação entre instrução e educação. Os espaços físicos de formação eram escassos, conforme o texto diz:

Hábitos como ir à escola, ao teatro, à biblioteca, às reuniões, aos salões, à rua passear e outros, foram aqui construções sociais tardias, em comparação à realidade europeia. Não faltavam apenas os hábitos, faltavam também, mesmo no Rio de Janeiro, espaços físicos adequados para tal, que passaram a ser construídos após a presença da Corte portuguesa (BENCHIMOL apud SILVA, 2000, p.42)

Os espaços escolares também eram espaços que demonstravam hierarquização, considerando que nem todos tinham liberdade para acessá-los, especialmente os escravos e libertos pobres.

Ao caracterizar os espaços escolares, Silva (idem) descreve os espaços das escolas da Corte (Sacramento, São José, Santa Rita, Engenho Velho, Candelária e Santana) como espaços "exíguos, escuros e úmidos". Assim foi o início da expansão da rede pública. Para ela, a Lei de 1827 já faz uma diferenciação e assinala uma desigualdade. Citando os primeiros artigos da Lei, observa a existência de uma legalidade para exclusão no ensino público.

Pretextado ensinava os meninos em sua casa, as primeiras letras e a contar. Para ele, isto era reconhecido como o seu trabalho, ou como mencionamos, era mais uma atividade que fazia entre uma e outra? O livro de Silva (2000) nos instiga a buscar esta resposta. A história de Pretextato provoca e propõe a existência de outras experiências, que são chamadas de "alternativas". Aparentemente, a afirmação da autora é que a liberdade é uma construção histórica, envolvida em aspectos cotidianos e também nas contradições da época, através da relação liberdade/propriedade.

\section{Considerações finais}

O livro traz no título, "aprender com perfeição e sem coação", o argumento da solicitação de Pretextato e dos pais de seus alunos ao solicitar o funcionamento da escola, ao considerarem que um professor "preto" seria fundamental para maior aproximação das crianças com o professor. Pelo livro, aprende-se que, no processo de ensino aprendizagem, é necessário ir além do 
conteúdo, haver a aproximação entre educador e educando e a construção de uma identidade e afetividade necessárias à aprendizagem.

Desta forma, o texto de Silva (2000) se faz extremamente atual, nos auxiliando a pensar nas questões do presente:

Na relação entre professor e aluno, as pesquisas mostram que há hierarquização das crianças. As brancas recebem mais atenção e manifestações afetivas de professores que as demais; os elogios são feitos a elas não como pessoas: são inteligentes, bonitas, espertas, etc. No caso das crianças negras, são feitos elogios às tarefas que estão bem feitas, mas não a elas como seres-humanos dignos de admiração e incentivo (CARNEIRO, 2009, p.14)

Como afirma o texto citado, estudos indicam a presença de estereótipos de professores em relação à educabilidade das crianças negras e pobres, que contribuem para configurar negativamente a auto-estima dos alunos negros, o que corrobora para o fracasso escolar.

$\mathrm{Na}$ época estudada por Silva (idem), os espaços escolares também eram espaços de hierarquização, considerando que nem todos tinham liberdade para acessar estes espaços, e os que eram livres para isto sofriam controle. Porém, vale salientar que Pretextato, como professor e também os pais dos alunos de Pretextato utilizaram-se do espaço escolar como lugar de aprendizado, mas também lugar de resistência, na busca pelo conhecimento como estratégia de luta e contra o racismo. Aprender a ler e escrever potencializava espaços de "liberdade" e de mobilidade. À autora do livro cabe o mérito de reconstruir sua historicidade no cuidadoso trabalho com fontes documentais da época. 


\section{VII \\ A RESPOSTA REPUBLICANA AO PROBLEMA DA INFÂNCIA POBRE - O livro de Milton Ramon de \\ Oliveira $^{*_{1}}$}

Maria Ciavatta

\section{Introdução}

Milton Ramon Pires de Oliveira $^{2}$ trata de um fenômeno recorrente na sociedade brasileira., a presença das oligarquias latifundiária e empresarial brasileiras que sempre foram pródigas em manter suas riquezas e privilégios. $\mathrm{E}$ sempre estiveram preocupadas em tratar como problema, como "questão social", as lutas das classes trabalhadoras e a infância pobre, buscando atenuar seus males com o assistencialismo religioso e as iniciativas do Estado republicano. O livro em questão traz uma fundamentada análise de sociologia histórica sobre os patronatos agrícolas, criados para formar "cidadãos úteis" no início do século XX.

Ainda hoje, encontramos pequenos vendedores nas ruas das grandes cidades, apesar da proibição legal do "Estatuto da criança e do adolescente" (Lei n. 8.069 de 13/7/1990), de proibição do trabalho infantil a menores de 14 anos, art. 60). É como se estivéssemos em um passado sempre presente na pobreza de grande parte da população trabalhadora nos dias de hoje ${ }^{3}$. Oliveira apresenta uma das soluções assistencialistas e de controle social da infância pobre, gerada pela desigualdade das classes sociais que atravessa a Colônia e o

\footnotetext{
*DOI - 10.29388/978-85-53111-86-2-f.131-146

${ }^{1}$ OLIVEIRA, Milton Ramon de. Formar cidadãos úteis: os patronatos agrícolas e a infância pobre na Primeira República. Bragança Paulista, 2003. Este texto é parte do Projeto de Pesquisa CIAVATTA (2012). Agradecemos a Diogo Henrique Araújo de Oliveira a participação na discussão inicial deste trabalho

${ }^{2}$ Milton Ramon Pires de Oliveira, possui graduação em Ciências Sociais pela Universidade Federal Fluminense (1984), mestrado em Educação pela Universidade Federal Fluminense (1991). O livro em análise é produto de sua tese de Doutorado em Educação pela Universidade Federal do Ceará (2000). Professor associado na Universidade Federal de Viçosa até 2017, quando aposentou-se. Tem experiência na área de Educação, com ênfase em Educação Infantil, História, Sociologia e Antropologia da Educação, atuando principalmente nos seguintes temas: história do ensino agrícola; infância, lúdico e educação; relações étnicas; e cultura popular.

3 "Em 2017, os 10\% da população com os maiores rendimentos detinham 43,3\% da massa de rendimentos do país, enquanto a parcela dos $10 \%$ com os menores rendimentos detinha $0,7 \%$ desta massa." Disponível em: <https://agenciadenoticias.ibge.gov.br/agencia-sala-deimprensa/2013-agencia-de-noticias/releases/20843-pnad-continua-10-da-populacaoconcentravam-quase-metade-da-massa-de-rendimentos-do-pais-em-2017.html>. Acesso em: 22 jul. 2018.
} 
Império, mantendo-se na República proclamada em 1889. São os patronatos agrícolas, 20 unidades, criadas de 1918 a 1926 (OLIVEIRA, 2003, p. 35-37).

No estudo de sua obra, buscamos identificar e analisar as categorias teóricas gerais e as categorias específicas do campo de pesquisa Trabalho-Educação. No primeiro momento, refletimos sobre as oligarquias e a Primeira República. A seguir, apresentamos as fontes e os procedimentos utilizados pelo autor, na pesquisa. Por último, analisamos algumas das categorias utilizadas na escrita da história de Trabalho-educação no tema focalizado.

\section{As oligarquias, o trabalho e a educação na Primeira República}

Procuramos compreender os fundamentos sociais do tipo de instituição que foram os patronatos agrícolas. Oliveira (idem) destaca, em seu estudo, "a conformação da força de trabalho" e a presença do Estado e das forças sociais no poder. Fábio Konder Comparato (2017) permite compreender dois dos fatores estruturantes das sociedades, no caso, a brasileira, que são as relações de poder e a consciência social que são aceitas ou rejeitadas na organização dos grupos dominantes - que interpretamos como o poder nas relações entre e intraclasses, a consciência social e a adesão aos valores e à cultura que dão forma às relações sociais

Nos termos de Marx e Engels (1979), "As ideias da classe são, em cada época, as ideias dominantes, isto é, a classe que é a força material dominante da sociedade e, ao mesmo tempo, sua força espiritual dominante" (p. 72, grifos do autor). Nos seus termos, Gramsci (1978) discute o "homem coletivo" e o "conformismo social" que constituem a

Tarefa educativa e formativa do Estado, que tem sempre o fim de criar novos e mais altos tipos de civilização, de adequar a "civilização" e a moralidade das mais vastas camadas populares às necessidades do contínuo desenvolvimento do aparato econômico de produção e, portanto, de elaborar também novos tipos de humanidade. (p. 223).

Comparato (ibid.), com base no direito romano, distingue a potestas, "o poder consentido do homem sobre o homem", e o dominium, "o poder sobre coisas e objetos". Em sua concepção, o núcleo semântico do poder é "a capacidade de imposição de uma vontade a outra" (p. 12). Ambos os sentidos do poder estão presentes na constituição da sociedade brasileira, primeiro na colonização e, a seguir, na escravidão, no poder de vida e de morte sobre os territórios, os súditos e os escravizados; depois nas condições desiguais de renda e de acesso aos bens produzidos e aos serviços sociais (trabalho, educação, saúde, moradia, segurança, previdência).

Outra questão, abordada pelo autor, é a distinção aristotélica entre o poder de poucos, a oligarquia, e o poder da plebe, do povo, a democracia. 
Comparato (ibid.) continua: “[...] a oligarquia é o regime político próprio da civilização capitalista que no presente é a civilização mundial. Importa, entretanto, acrescentar que essa oligarquia é sempre dissimulada sob a falsa aparência de um regime de base popular". Desde a ascensão da burguesia, o soberano de fato é "formado pelo conjunto dos poderes econômicos privados, intimamente ligados aos grandes agentes estatais". Citando Fernand Braudel, conclui que "o capitalismo só triunfa quando se identifica com o Estado, quando é o Estado" (p. 15 e 17).

Atuando como agentes dessa coligação oligárquica, tivemos desde sempre as corporações militares e, até, praticamente, o último quartel do século XX, a Igreja Católica. Seus integrantes sempre gozaram de uma posição privilegiada, em relação aos demais cidadãos, mas um privilégio de fato e não de direito.

O grande ausente desse regime oligárquico é e sempre foi o povo (ibid., p.19).

Essas premissas de análise nos permitem compreender não apenas a estrutura de classe oligárquica, do país, mas também, as condições de vida e de educação da população destinada ao ensino limitado ao aprendizado das atividades produtivas e noções elementares de aritmética e linguagem. É o que evidenciam os estudos de Oliveira (ibid.), Faria Filho (2001) e os estudos exaustivos de Fonseca (1986) e Cunha (2000).

$\mathrm{Na}$ análise das relações de poder na sociedade brasileira, Compartato (ibid.) mostra que, desde o regime colonial, no século XVI, o país "foi marcado pela doação de terras públicas aos senhores privados e pela mercantilização dos cargos públicos". Associaram-se "os potentados econômicos privados aos principais agentes do Estado" de tal forma que as mudanças de regime político sempre foram fruto de "uma dissidência entre os grupos componentes da oligarquia" (p. 18 e 20). Não foi diferente na Proclamação da República. A corporação militar descontente, após a Guerra do Paraguai, que pleiteava manter o protagonismo no quadro dos poderes públicos, encontrou apoio nos grandes latifundiários do Sudeste "decepcionados com a Lei do Ventre Livre e a Lei Áurea, impostas pelo poder monárquico” (p. 22).

Seu pensamento, aqui apresentado em termos breves, sintetiza os fundamentos estruturantes da sociedade brasileira que são o contexto do livro de Oliveira (ibid.). Os patronatos agrícolas da Primeira República eram parte das ações da oligarquia no intuito de formar e conformar a força de trabalho, com a intervenção direta ou com o apoio do Estado a instituições privadas. Juristas e médicos, engenheiros e militares, todos demandavam espaços nos debates sobre como deveria ser o país. "Miravam-se nas cidades europeias onde investimentos foram implementados visando ao controle da população e à consolidação da racionalidade proclamada pela modernidade, com base na organização da existência pela lógica da produção industrial” (p. 10). 
Tratava-se de buscar os meios de transformar em "cidadãos úteis" à República, uma população recém-liberta do trabalho escravo, convertida legalmente, mas não de fato, com meios materiais, em trabalhadores livres. O conceito de trabalho é ressignificado como regulador e civilizador da sociedade. Pelo trabalho e pelo controle que continuaria a ser exercido sobre a população, haveria de se forjar "[...] o sentimento de "nacionalidade", superar a "preguiça" e a "rotina" associadas a uma sociedade colonial" e abrir-se aos padrões europeus (CHALHOUB, 1986, p. 29).

A potestas e o dominium que vigiam sem limites, salvo a resistência, sempre negada e punida, de escravos durante a Colônia e o Império. "o mundo do trabalho estava obviamente circunscrito na esfera mais ampla do mundo da ordem, que consagrava o princípio de propriedade". As ideias geradas na capital da República eram as ideias que orientavam as políticas de criação da nova nacionalidade, a exemplo do projeto de repressão à ociosidade de Ferreira Vianna, apreciado na Câmara dos Deputados em julho de 1888, pouco tempo depois da lei da abolição em 13 de maio (CHALHOUB, id., p. 39 e 40).

As transformações econômicas exigiam uma nova ordenação do trabalho. As classes dominantes percebiam o mundo como se tivesse havido um nivelamento de todas as classes. A ameaça tinha uma de suas expressões no combate à ociosidade, na inculcação da ordem, no combate aos vícios que "seriam vencidos através da educação, e educar libertos significava criar o hábito do trabalho através da repressão, da obrigatoriedade" (ibid., p. 39-42).

A análise do contexto do início da República onde Oliveira (id.) situa as instituições de amparo à infância e à adolescência pobre é convergente com vários outros estudos sobre a época. Ente outros, Russel-Wood (1981), Rizzini (1993). "Gilberto Freyre (1982) também cita o deslocamento da atenção para questões que ascendem ao status de problemas sociais à medida que ga nham visibilidade nos espaços das cidades" (apud OLIVEIRA, id., p. 12).

Turazzi (1989), trata da "euforia do progresso e a imposição da ordem" no contexto da indústria, no início do século XX e reitera "a moralização pelo trabalho" existente nas relações com o trabalho no campo:

Se de um lado o ranço escravocrata exalava um forte preconceito contra o trabalho manual e uma inclinação para o bacharelismo, de outro lado [...] valorizava o trabalho e condenava o ócio, a indolência, a sexualidade 'desregrada' e todas as formas de expressão da cultura popular que escapavam à lógica da sociedade capitalista (p. 111-112).

\section{Fontes e procedimentos teórico-metodológicos da pesquisa}

Fontes de pesquisa são o que resta da memória humana, materializada em palavras, imagens, objetos, documentos escritos, orais, iconográficos. As fontes registram a história humana vivida em suas particularidades, pelos sujei- 
tos sociais. Em termos breves, o uso das fontes também tem uma história porque os temas, as concepções de mundo e os interesses dos pesquisadores variam no espaço-tempo de suas trajetórias de vida, contextos político-sociais e identidades culturais.

A relação dos historiadores com as fontes tem variado ao longo do tempo, desde "os documentos [vistos] como fontes de verdade, testemunhos neutros do passado, aos que analisam seus discursos, reconhecem seus vieses, desconstroem seu conteúdo, contextualizam suas visões" (JANOTTI, 2006, p. 10; 25), até os que veem as fontes apenas como expressões discursivas, aparentemente, desencarnadas (CIAVATTA, 2015). As fontes de que dispomos são registros do passado que se projetam no presente e permitem o reconhecimento dos acontecimentos, suas consequências no presente e a projeção do futuro (CIAVATTA, 2002).

As fontes de Oliveira são secundárias e primárias, isto é, escritos de outros autores afins com a questão, as primeiras, e fontes de época, as segundas. Entre as primeiras, estão os autores que produziram uma literatura específica sobre a cultura política e econômica na Primeira República (a exemplo de CHALLOUB, 1986; TURAZZI, 1989); ou sobre a infância e adolescência pobres (entre outros, BRAGA, 1993; ALVIM; VALADARES, 1988); ou sobre o controle policial da população pobre (v. BRETAS,1997) ou sobre as instituições e uma visão geral do tema no país (como RIZZINI, 1993); e os estudos sobre a educação no período (v. NAGLE, 1975).

Para Oliveira, as fontes de época, os arquivos documentais, são decisivas para apreender a particularidade das instituições que combinaram trabalho e estudo com finalidades assistenciais, de controle da infância e da adolescência pobres, através da educação para o trabalho no campo, os patronatos agrícolas. São os Relatórios do Ministério da Agricultura, Indústria e Comércio (MAIC) de 1909 a 1934; são documentos sobre a Polícia do Distrito Federal ou "produzidos por diversos setores estatais e da sociedade [...] [que] em geral solicitavam vagas para menores em instituições de assistência e disciplinar", da Série Justiça do Arquivo Nacional (ibid., p. 17-21).

$\mathrm{O}$ autor procede detalhadamente com uma narrativa apoiada em aspectos sociais, sobre os menores internados nos patronatos, transcrevendo trechos de documentos legais (a exemplo de p. 51-52), declarações de autoridades (p. 63-64), ofícios administrativos (p. 67), pedidos de pais ou responsáveis (como na p. 71), oriundos de sua pesquisa documental ou transcrevendo outros autores que estudaram a questão. São abundantes, também, os dados quantitativos, tais como localização, número e data de criação e de inauguração dos patronatos (id., p. 36-37); idade e quantidade dos menores; internações e desligamentos (p. 73 e 75); quantidade e envio de menores para patronatos agrícolas pela Polícia do Distrito Federal e pela Diretoria de Povoamento (p. 77 e 78$)$. 
As fontes disponíveis permitem a apresentação dos mecanismos de internação e assistência aos menores de acordo com as exigências econômicas, políticas e culturais da época. Não há registro da resistência de crianças e adolescentes envolvidos nessa ação de socialização pela assistência, o trabalho e a educação, salvo na breve menção a fugas quando o MAIC registra as razões de desligamento de menores ${ }^{4}$.

\section{Conceitos e categorias - A escrita da história de Milton Ramon de Oliveira}

As ciências sociais são ricas de categorias e conceitos nas diversas vertentes teóricas de produção do conhecimento. Os pesquisadores escolhem as categorias e conceitos que melhor correspondem à sua visão de mundo e aos objetivos da investigação sobre os acontecimentos vivenciados ou de que tomam conhecimento.

Categorias e conceitos referem-se a seres em relação, mas servem para ordená-los e compreendê-los de modo diferenciado, embora sejam termos utilizados quase indistintamente nos trabalhos científicos, podendo até ter o mesmo significado, enquanto termos que se referem a algum atributo dos seres. No sentido estrito de classificação, as categorias podem servir a uma ordenação mais precisa desses atributos.

Os conceitos devem conter, necessariamente, densidade teórica para dar sentido explicativo aos fenômenos aos quais se aplicam. Alguns são gerais, e devem servir ao universo amplo de todos os seres; outros são específicos a um campo de estudos e podem ser objeto da história ou da historiografia, a exemplo de trabalho e educação no caso deste livro ${ }^{5}$.

$\mathrm{Na}$ pesquisa histórica de base marxista, categorias e conceitos são fundamentais para a ordenação e compreensão dos fenômenos e de objetos de estudo, e de entendimento sobre suas relações com os demais seres, com os quais constituem uma totalidade social, Conceitos são categorias gerais, densas de conteúdos teóricos que permitem explicar os fenômenos como mediações, como processos sociais complexos. É elucidativo, como se constrói o conceito, o exemplo da população, ponto de partida como um nome, um substantivo, uma abstração, e, como conceito, concreto pensado, ponto de chegada com suas particularidades históricas, "síntese de múltiplas determinações" (MARX, 1977, p. 228-229) ${ }^{6}$.

Para Traverso (2012) quatro são os grandes pressupostos teóricometodológicos da pesquisa histórica, procedimentos iluminados pela teoria: (i)

\footnotetext{
4 "O Ministério recorria à Polícia do Distrito Federal quando havia casos de fugas de unidades dos patronatos agrícolas, com o objetivo de capturar os menores" (OLIVEIRA, op. cit., p. 101).

${ }^{5}$ Sobre categorias e conceitos, v. Ciavatta (2015, p. 40).

6. São determinações históricas, no caso de população, o trabalho assalariado, suas condições de vida e de trabalho, o capital etc. (MARX, op. cit., p. 228).
} 
a contextualização, (ii) a historicização, (iii) a comparação e (iv) a conceituação. São pressupostos que orientam a busca e o tratamento das fontes segundo um conceito de realidade, uma visão do mundo e uma concepção do ser humano do historiador. As quatro categorias enunciadas concorrem para a apreensão histórica dos fenômenos. Constituem um roteiro teórico-prático de pesquisa social a partir das fontes disponíveis (CIAVATTA, 2015, p. 49)

Oliveira (id.) não se detém em enunciar categorias e conceitos, o que não significa que não tenha pressupostos de pesquisa. É possível identificá-los no decorrer de sua narrativa. Inicialmente, faz a contextualização de seu objeto através da busca de fontes secundárias e primárias, histórico-sociológicas, que tratam da sociedade brasileira na Primeira República ou República Velha (1989-1930), divisão política usual entre os historiadores brasileiros, a exemplo de Carone (1974 e outros).

O autor não explicita esse procedimento, mas conduz sua análise a partir do contexto da época: a presença do Estado, a sociedade patriarcal do período e a quantidade de instituições assistenciais presentes no Rio de Janeiro, capital da República, "caixa de ressonância de questões em debate pelo país e enquanto vitrine para as demais cidades". Destaca a presença de ordens religiosas católicas voltadas para a questão da pobreza, particularmente, feminina, orientadas pelo assistencialismo, "o que viabilizava o controle desse segmento populacional recortado pelas paróquias" e "a articulação da assistência aos pobres ao modelo fabril" (p. 11 e 12).

No contexto de assistência aos desvalidos estavam também as "pressões de médicos e higienistas, que propunham a assistência baseada nos conceitos de higiene e eugenia, contrapostos aos hábitos de criação dos filhos pelas famílias" (id., p. 13). Era necessário reintegrar os pobres e desvalidos "no processo de produtividade da sociedade, ou seja, reintroduzi-los nos circuitos produtivos" (VAN BALEN, apud OLIVEIRA, 2003, p. 13). O Estado passou a "subvencionar com regularidade", o setor privado, atuando politicamente, indo além dos objetivos assistenciais.

Para Traverso (ibid.), a historicização "Significa a necessidade de enfrentar os fatos e as ideias em uma perspectiva diacrônica, capaz de captar as transformações no tempo." Recupera Benjamin e sua crítica ao tempo linear “"homogêneo e vazio' que entra em empatia com os vencedores e desemboca irremediavelmente em uma visão apologética do passado". Defende um "historicismo crítico que afirma com força a ancoragem na história, não obstante a multiplicação dos sujeitos e suas representações literais e rasteiras" (p. 17). Entendemos que, nesta expressão, Traverso busca sinalizar a superação do historicismo factual, tradicional.

A historicização do tema está presente na escrita de Oliveira que concentra-se em recuperar os autores e documentos que tratam da infância e da adolescência pobres e das instituições que se ocupavam desses "menores", ter- 
mo da época para designar as crianças e adolescentes pobres ${ }^{7}$ nos distantes anos do início do século XX

Trabalho e educação seriam princípios que responderiam à repressão e ao controle da "vadiagem", classificação jurídica expressa na legislação dos menores:

“A Lei n. 2.059 de 1924, quando trata dos menores abandonados, define '[...] vadios como aqueles que vivessem em casa dos pais ou tutor, mas que se mostrassem refratários a receber instrução ou entregar-se ao trabalho sério e útil, preferindo vagar pelas ruas e logradouros públicos”' (BRAGA, 1993, apud OLIVEIRA, op. cit., p. 14).

Outro pressuposto apresentado por Traverso (id.) é a comparação. Entendemos que fazer analogias, comparar são processos inerentes ao conhecimento (CIAVATTA, 1992; 2015). Precisamos distinguir um fenômeno de outro ou um objeto de outro, e nomeá-los para poder afirmar algo sobre sua natureza, propriedades e relações. E situamos cada um no seu espaçotempo histórico, para poder afirmar sua presença e participação nos acontecimentos que constituem os pequenos e os grandes acontecimentos da vida humana.

Oliveira (id.) qualifica a infância e a adolescência pobres na Primeira República, comparando, mesmo que brevemente, a denominação crianças e adolescentes das classes sociais abastadas, com os "menores", as crianças filhas homens libertos e suas famílias, suas instituições (escolas, patronatos) e os valores presentes nas ideologias ${ }^{8}$ vigentes nas ações levadas adiante, junto à parcela pobre da população brasileira. Foi necessário comparar os grupos e classes sociais da época para poder afirmar que, no Rio de Janeiro,

[...] quase $1 / 3$ da população [estava] inserida em atividades classificadas como na fronteira da legalidade, sendo os registros de embriaguez, jogo, desordem e vadiagem os que eram realizados com maior frequência pela polícia", e produziam a "preocupação

\footnotetext{
${ }^{7} \mathrm{O}$ termo "menor", tradicional na legislação brasileira e na linguagem corrente, para designar crianças e adolescentes pobres, foi intensamente criticado após o fim da Ditadura (de 19641985), particularmente, quando da tramitação no Congresso Nacional e aprovação do Estatuto da Criança e do Adolescente (Lei n. 8.069 de 13 de julho de 1990). Além da crítica ao uso diferenciado do termo para designar os filhos das classes médias e altas, que não eram "menores", mas sim, "crianças e adolescentes", o Art. $5^{\circ}$.do Estatuto determina que "Nenhuma criança ou adolescente será objeto de qualquer forma de negligência, discriminação, exploração, violência, crueldade e opressão, punido na forma da lei qualquer atentado, por ação ou omissão, aos seus direitos fundamentais".

${ }^{8}$ Com base em Marx (1979), concebemos as ideologias como representações que atendem a in teresses expressos nos discursos e ações das diversas classes sociais, particularmente, as classes dominantes que têm o poder de mando e de formação da consciência social em cada época.
} 
republicana com o controle da população marginal da cidade (CARVALHO, 1987, p. 36, apud OLIVEIRA, op. cit., p. 15).

O quarto pressuposto de Traverso (id.) é a conceituação ${ }^{9}$. que está presente ao longo de todo o livro de Oliveira. Além do tempo-espaço da pesquisa, a República e suas instituições no início do século XX, a conceituação caracteriza seu trabalho científico, e será detalhada nesta análise da escrita da história da "formação de cidadãos úteis" e a infância pobre nos patronatos agrícolas.

Sem declinar as categorias utilizadas, Oliveira (id.) revela um constante trabalho conceitual que dá forma e conteúdo à sua análise socio-histórica. Três são as grandes questões de introdução do tema, mediações históricas da "formação de cidadãos úteis": (i) a infância e adolescência pobres, (ii) a conformação da força de trabalho e (iii) os patronatos agrícolas. Outras categorias mais pontuais são recorrentes no texto: modernização, controle social, disciplinamento, preparo para o trabalho, educar e regenerar.

\subsection{A infância e a adolescência pobres}

A infância e a adolescência pobres são apresentadas através das condições políticas e culturais do Brasil na Primeira República, do constrangimento das elites da época com os trabalhadores libertos da escravidão e seus filhos, vistos como uma ameaça à sociedade. "Progresso e civilização", "Brasil moderno", "modelo europeu de civilidade", "o modelo de civilização garantidora da não-barbárie” (id., p. 23-24) eram termos correntes para expressar a categoria modernização nas aspirações da oligarquia da época. A ideia de "ficar em pé de igualdade com a Europa" estava presente no "cotidiano, nas instituições, na economia, ideias liberais etc.” (HERSCHMAN; PEREIRA, 1994, p. 12, apud OLIVEIRA, id., p. 24).

Le Goff (1996) afirma "a equivalência entre modernização e ocidentalização" que seria o modelo de "identidade nacional" para "nações atrasadas" (p. 185, apud OLIVEIRA, ibid.). Era o caso do Brasil, que aspirava deixar de ser "essencialmente agrícola" para se inserir em um mercado urbano, fabril, moderno. "O discurso, as ações, seu reconhecimento, eram perseguidos pelas elites locais, atentas aos interesses cujos centros decisórios situavam-se fora do país" (ibid.). O Ministério da Agricultura, Indústria e Comércio (MAIC) seria o principal órgão governamental capaz de fazer a "modernização técnica e econômica", racionalizando a agricultura com base em conhecimentos científicos (ibid.).

\footnotetext{
${ }^{9}$ Divergimos de Traverso (2012) que fala em conceitos como uma espécie de "tipos ideais", termo de origem weberiana que faz referência à ideia de modelo, uma representação racional de um fenômeno (burocracia, religião, economia etc.) para ajudar na sua compreensão (CIAVATTA, 2015, p. 49).
} 
Embora o autor não faça referência específica ao processo progressivo de libertação dos escravizado ${ }^{10}$ nas fazendas brasileiras, os estudos sobre $o$ período que se seguiu à lei de 13 de maio de 1888, revelam a insatisfação dos donos dos latifúndios com a nova situação institucional dos libertos, de seus trabalhadores. Ao problema da mão-de- obra, aliavam-se as aspirações "civilizatórias" de uma sociedade que criara as próprias bases da opressão e da pobreza, da ausência de educação e da destinação ao trabalho braçal na terra, aos trabalhos manuais e aos serviços para os grandes proprietários no campo e na cidade. Não são de estranhar as demandas ruralistas da Sociedade Nacional de Agricultura (SNA), que estão na origem do MAIC, desde seu congresso realizado em 1901. Pretendiam:

a) a diversificação produtiva; b) o associativismo; c) a criação de uma agência do aparelho do Estado permeável a suas petições e inquietudes; d) modernização da agricultura pelo ensino técnico e da mecanização e. finalmente, e) a multiplicação da pequena propriedade como estratégia de fixar a mão de obra no campo (MENDONÇA, 1997, p. 50, apud OLIVEIRA, id., p. 46).

Um aspecto focalizado pela historiadora Sonia Mendonça e reproduzido por Oliveira é o papel mediador

[...] dos conflitos intraclasse dominante agrária, contribuindo para a valorização do discurso modernizador acerca da agricultura [...] Ainda que ferrenho defensor da vocação eminentemente agrícola do país, o MAIC viria a constituir-se num dos principais responsáveis pela consolidação da dualidade entre campo/atraso x cidade/progresso" (MENDONÇA, 1997, p. 117, apud OLIVEIRA, id., p. 49, grifos do autor).

O preconceito contra os libertos, a infância e a adolescência pobres são parte da história da penúria dos trabalhadores e de suas famílias nas décadas que se seguiram à Lei da Abolição e à Proclamação da República. A obra revela o Estado autoritário, a repressão, a opressão dos libertos, a não incorporação da população brasileira a um projeto nacional de cidadania (id., p. 117).

\footnotetext{
${ }^{10} \mathrm{O}$ controvertido processo progressivo de libertação dos escravizados ocorreu pela Lei Eusébio de Queirós de 1850 (proibição do tráfico de escravos intra-atlântico), seguida pela Lei do Ventre Livre de 1871 (considerava livre todos os filhos de mulher escrava nascidos a partir da data da lei), pela Lei dos Sexagenários de 1885 (concedia liberdade aos escravos com mais de 60 anos de idade). e pela Lei Áurea em 1888 (extinguiu a escravidão no Brasil). Estas iniciativas oficiais não foram plenamente assimiladas pela sociedade e resultou, após 1888, no abandono da população liberta. Os preconceitos contra essa população foram o fruto perverso da desigualda de de classes e da ausência de uma política verdadeira de emancipação dos libertos da pobreza, da opressão do trabalho semiescravo, com meios materiais e sociais para levar uma vida dentro do ideário de cidadania proclamado pelas elites.
} 


\subsection{A conformação social da força de trabalho}

O debate sobre a infância e a adolescência pobres conduziam a um objetivo comum à oligarquia da época, "a conformação social da força de trabalho" que devia tornar-se ordeira e produtiva, disciplinada, de modo "a incorporar as formas de sociabilidade demandadas pelas relações sociais da produção capitalista". O modelo ideal de trabalhador era o imigrante, "enquanto os nacionais eram qualificados como preguiçosos". Os recursos para mudar essa situação, desde 1888, eram a "repressão à ociosidade" e "a transformação do liberto em trabalhador" (id., p. 15).

O atraso do campo seria corrigido com a intervenção dos cientistas na produção e com a instrução agrícola e preparação de trabalhadores em agropecuária. "Contribuir para a formação do mercado de trabalho livre e para a disciplinarização da força de trabalho eram os objetivos que diversas agências da sociedade implementavam, o MAIC entre elas" (id. p. 54). Cuidava-se de " [...] agir sobre uma população tida como ignorante, ministrando-lhe conhecimentos práticos a respeito do trato com a agricultura, eis o sentido mais amplo atribuído à chamada instrução elementar agrícola no bojo desse debate" (MENDONÇA. 1997, p. 90, apud OLIVEIRA, id., p. 55).

Oliveira sinaliza a recorrência do tema e a presença das "instâncias do Estado e fora delas ${ }^{11}$. especialmente as organizações não governamentais" (id., p. 9); menciona personagens semelhantes (negros, mulheres, trabalhadores, prisioneiros) tomados como problema social - fenômenos que observamos até os dias atuais. A pesquisa "volta-se para esse tema, inscrevendo-o entre os investimentos direcionados para a conformação da força de trabalho" (ibid., p. 15). Urgia civilizar os pobres.

Três mediações principais concretizam esse ideário no tratamento dispensado a eles: o controle social que se exercia pela ação policial aos considerados vadios ou perigosos; o preparo para o trabalho; e o disciplinamento em instituições assistenciais.

A presença da Polícia do Distrito Federal por toda a cidade, incumbida do controle social da população "produzia ações específicas voltadas para intervir na situação da infância pobre [...]". Assim, "são afastados os que andavam descalços nas novas ruas e os pedintes.” (id,, p. 90) ${ }^{12}$.

O preparo para o trabalho fazia-se articulado ao disciplinamento nos patronatos agrícolas e em outras instituições. Segundo o autor, "Nas primeiras décadas do século XX, as questões sociais eram inseridas num universo buro-

\footnotetext{
11 "Instâncias do Estado e fora delas", é uma categorização utilizada pelo autor. Em uma visão marxista, a partir de Gramsci (1978), falaríamos do Estado como a sociedade política, e da sociedade civil, composta pelos aparelhos privados de hegemonia.

${ }^{12}$ Entre outros autores que trataram da modernização da cidade do Rio de Janeiro e do afastamento dos pobres do centro da cidade para áreas mais distantes, a exemplo do desmonte do Morro do Castelo. V. Ciavatta (2002).
} 
crático e repressivo, herança das recentes relações sociais fundamentadas no trabalho compulsório, entre outros aspectos" (id., p. 15), próprio do escravismo vigente durante quatro séculos no país.

\subsection{Os patronatos agrícolas}

Os patronatos agrícolas são o objeto exemplar da cultura política e econômica, trazido pelo autor. Pela quantidade e diversidade das instituições existentes, Oliveira situa seu estudo na capital federal, o Rio de Janeiro. As tendências diversas das intervenções são expressas por um conjunto de mediações que reconstroem o tema na sua totalidade social ${ }^{13}$ : a atuação das ordens religiosas da igreja católica; as propostas articuladas ao modelo fabril; a presença e a palavra de juristas, políticos e médicos; a articulação das iniciativas dos poderes privado e estatal; as propostas centradas na relação entre o trabalho e a educação "enquanto princípios eficientes para promoverem modificações na situação e na trajetória daqueles que ingressavam nas instituições" (id., p. 1314).

A proposta dos patronatos agrícolas e de 1918. No mesmo ano foram criadas e implementadas cinco unidades; duas em 1919 e uma em 1920, e outras nos anos seguintes, até 1926, em um total de vinte unidades; primeiro nos estados de Minas Gerais e São Paulo e, depois, em Pernambuco, Rio Grande do Sul, Pará e Santa Catarina. O autor registra a distinção entre os patronatos que recebiam menores encaminhados com intermediação da polícia e as Escolas de Aprendizes Artífices, destinadas ao ensino profissional, criadas em 1909 pelo Presidente Nilo Peçanha ${ }^{14}$.

A documentação consultada por Oliveira permitiu conhecer dados sobre a criação das instituições, a clientela dos patronatos, as formas de ingresso, de desligamentos e a quantidade de "menores" nos patronatos. Grande parte ingressava através de solicitação padronizada à Polícia do Distrito Federal, a pedido dos pais, dos responsáveis ou de outras pessoas. Também ingressavam

[...] menores que se apresentavam à própria polícia, visto não disporem de lugar para ficarem; outros eram encontrados nas ruas, resultado da ação da própria polícia que os detinha, junto com outros indivíduos, todos classificados na valorização do trabalho e punição daqueles que não

\footnotetext{
${ }^{13} \mathrm{O}$ autor não utiliza os conceitos marxistas de mediação e de totalidade social. Nós o utilizamos para expressar, neste referencial teórico, a qualidade científica do texto: a mediação é compreendida como processo social complexo que é constituído e constituinte de determinada totalidade social, "uma síntese de múltiplas determinações" (v. MARX, 1977, p. 227)

${ }^{14}$ O Decreto n. 7.566 de 3 /9/1909, contém o Considerando “[...] não só habilitar os filhos dos desfavorecidos da fortuna com o indispensável preparo técnico e intelectual, como fazê-los adquirir hábitos de trabalho profícuo, que os afastara da ociosidade ignorante, escola do vício e do crime".
} 
eram incorporados em relações sociais de produção reconhecidas e valorizadas socialmente. (id., p. 66-67).

A pesquisa revelou uma íntima relação entre os patronatos agrícolas e a Polícia do Distrito Federal, com a participação do Juízo e Órfãos e Ausentes do Rio de Janeiro. Embora não contemplado pelos estudos de educação profissional, o objetivo de "regenerar os menores" era a ponte entre as duas instituições: "As estatísticas oficiais apresentam um quadro dos menores recolhidos pela polícia e encaminhados a 'juízes, à Escola XV de Novembro ou a patronatos agrícolas"' (BRETAS, 1997, apud OLIVEIRA, id., p. 19). O autor transcreve alguns documentos oficiais das autoridades governamentais e policiais, identificando textualmente menores recolhidos e os encaminhamentos dados a eles (a exemplo das pp. 39-41).

Destaca a atuação da polícia no quadro complexo da sociedade da época, com práticas repressivas, particularmente no Rio de Janeiro: "À europeização de seu perfil urbano correspondeu um crescimento da polícia, demandado pela complexificação do perfil social dos habitantes e das relações entre os grupos" (id., p. 94).

Do ponto de vista de nossa análise da historiografia do período, não se tratava apenas das relações entre grupos. Basicamente, devia-se, como se deve ainda hoje, na segunda década do século XXI, a uma estrutura de classes sociais com acesso extremamente desigual aos benefícios gerados pela riqueza social. O modo de produção capitalista e sua oligarquia detentora do poder econômico e político, mantêm uma relação adversa entre os donos do capital e os trabalhadores.

Relatório do Ministério da Agricultura de 1924 sobre os patronatos agrícolas, registra um total de 1.085 internações, 384 desligamentos e um total de 2.174 atendidos nas 17 unidades existentes nos diversos estados da federação, no período entre 1918 e 1927 (id., p. 75). Os desligamentos ocorriam em caso de fuga, falecimento ou por solicitação do pai, parente, tutor ou pessoa interessada na retirada do menor, nas seguintes condições: "salvo mandado de juiz competente [...] [não poderia ser] antes do prazo de doze meses, a contar da data da matrícula e sem que tenha adquirido os conhecimentos precisos no estudo da língua materna." Exigia-se ainda atestado firmado de que teria capacidade moral e recursos materiais para manter o menor, mas, detalhe, o requerente "deve indenizar a fazenda Nacional das despesas feitas com a assistência prestada [...]" (id., p. 78-79).

"Educar e regenerar" eram as finalidades atribuídas aos patronatos agrícolas. Elas determinam os dois modelos pretendidos: "o escolar - voltado para o ensino profissional, educando para o trabalho agropecuário - e o correcional - regenerar por meio da vida no campo com a predominância da reclusão e da ênfase nos aspectos disciplinares" (id., p. 32-33). Grande parte do tempo era ocupada pelo ensino de ofícios ou arte, mas cabia o trabalho na ter- 
ra, para implementar atividades produtivas e manter "o ensino profissional que tinha entre suas atribuições concorrer para a manutenção dos serviços oferecidos aos alunos e funcionários". Parte da produção servia à instituição e parte era comercializada (id., p. 33) ${ }^{15}$.

A assistência se fazia em regime de internato, incorporando também "atendimento médico e odontológico, além de cuidados físicos, quer por meios dos exercícios e da vida ao ar livre, quer por meio da alimentação e condições higiênicas de moradia" (ibid.). Considerava-se que havia falta de formação moral nas famílias para dar aos filhos uma formação adequada. Por meio do trabalho estariam assegurados os "princípios educativos, de socialização e morais" (ibid.)

Controle social, controle urbano, controle das classes perigosas são categorias reiteradas pelo autor ao enfocar a articulação do tratamento dado à infância e adolescência pobres para a conformação de uma força de trabalho por meio dos patronatos agrícolas. A eles "era atribuída a possibilidade de concorrer para o aumento progressivo da capacidade produtora, impulsionando a transformação econômica do país" e instituindo o ensino profissional. E ainda concorreria "para estabelecer o equilíbrio entre a população das cidades e a populaşão dos campos" (id., p. 26, grifos do autor).

\section{Considerações finais}

Reconhecemos o valioso trabalho historiográfico do autor, que se torna, muitas vezes, uma denúncia contundente sobre a herança escravista que organizou a República e perdura até hoje, com os resquícios de um passado que se fez de modo cruel no trato com a população negra escravizada e com os trabalhadores libertos. Ontem como hoje, nossas elites herdeiras da terra e da riqueza produzida no país, aliam-se a interesses externos e buscam subjugar a população trabalhadora e seus filhos à produção e à produtividade capitalista.

Sob o ideário da modernização e do progresso, os detentores dos meios de produção no sistema capitalista, a oligarquia detentora do poder econômico e político, organizou a República, com a ação da polícia, para o controle dos hábitos de vida e de trabalho da infância e da adolescência pobres. O autor situa seu objeto de estudo no tempo-espaço da Primeira República ou República Velha. Mas muitos dos traços e estratagemas do período perduram no tempo, no trato com os moradores das periferias das grandes capitais.

\footnotetext{
${ }^{15}$ Oliveira (id.) informa que os relatórios contêm, para prestação de contas e demandas de recursos para o exercício do ano seguinte, os produtos, as quantidades e os valores, além de fotos ilustrativas das atividades (p. 33). Este modelo de escola esteve presente no Art. 10 ${ }^{\circ}$. Do Decreto n. 7.566 de 25/09/1909 da criação das Escolas de Aprendizes Artífices. É claramente retomado nos anos 1970 (a exemplo de CENAFOR, 1982), no período da Ditadura Civil-militar (1964-1985) e foi alvo de debates e de crítica.
} 
Do ponto de vista de nossa análise da historiografia do período, não se tratava apenas das relações entre grupos dominantes, mas entre as classes sociais. Basicamente, devia-se, como se deve ainda hoje, na segunda década do século XXI, a uma estrutura de classes sociais detentores dos meios de produção e os trabalhadores. Estes têm apenas sua força de trabalho e acesso extremamente desigual aos benefícios gerados pela riqueza social.

Oliveira é parcimonioso na explicitação das categorias teóricas com que reconstrói a história das crianças e adolescentes e das instituições criadas para abrigá-los sobre rigoroso sistema disciplinar de trabalho no campo. Mas suas categorias analíticas estão presentes na apropriação de fontes documentais e de outros autores que se dedicaram ao estudo do tema. Três são as grandes questões de introdução do tema: a infância e adolescência pobres, a conformação da força de trabalho e os patronatos agrícolas. Outras categorias sobre aspectos mais pontuais enriquecem sua análise: modernização, controle social, disciplinamento, preparo para o trabalho, educar e regenerar.

Os patronatos agrícolas têm semelhanças com o Instituo João Pinheiro criado em Minas Gerais, em 1910, dentro do mesmo ideário de "'produzir" um cidadão disciplinado e um trabalhador apto ao trabalho assalariado na lavoura mineira", objeto de estudo do historiador Luciano Mendes Faria Filho (2001, p. 39). A cultura de classes que moldava todas essas instituições destinadas ao trabalho produtivo nas fazendas e nas fábricas, proclamava o ideário republicano da formação para a civilização imposta pelo regime capitalista. É o que evidenciam as pesquisas históricas do campo Trabalho-educação sobre crianças e adolescentes, sobre escolas profissionais, industriais e técnicas, e sobre a socialização de trabalhadores jovens e adultos. 

C - TRABALHO-EDUCAÇÃO DOS TRABALHADORES 



\title{
VIII \\ AS CONTRADIÇÕES DO MUNDO DO TRABALHO \\ NO SISTEMA SENAI - O livro de Marcelo Lima ${ }^{{ }^{*}}$
}

\author{
Jordan Rodrigues dos Santos \\ Lisia Nicoliello Cariello
}

\section{Introdução}

Marcelo Lima é graduado em Pedagogia pela UFES (Universidade Federal do Espírito Santo), tem mestrado em Educação pela UFES e doutorado em Educação pela UFF (Universidade Federal Fluminense). É professor adjunto II do DEPS-CE-UFES (Departamento de Educação, Política e Sociedade do Centro de Educação do Programa de Pós-graduação da UFES (Universidade Federal do Espírito Santo).

Esta obra (LIMA, 2007) tem uma relação estreita com seu autor. Marcelo Lima, que estudou no SENAI/ES (Serviço Nacional de Aprendizagem Industrial / Espírito Santo) consegue enxergar seu objeto sob dois pontos de vista: enquanto pessoa que participou da dinâmica da instituição e enquanto pesquisador. Com olhar investigativo, Lima se preocupa com métodos de análise e em comprovar (ou não) sua tese: a de que os novos métodos organizacionais e gerenciais da produção capitalista, bem como o desenvolvimento tecnológico pressionaram pela elevação da escolaridade do trabalhador. Mas, por outro lado, colocaram em xeque a qualidade de seus processos formativos em função das "demandas do mercado" e dos "novos paradigmas da produção". O autor analisa como esse processo se delineia historicamente no SENAI/ES.

A obra foi publicada em 2007 e traz seis capítulos, além da introdução e da conclusão. Logo na introdução, Lima define o assunto a ser tratado em seu livro, bem como as fontes utilizadas por ele. Segundo o autor,

[...] a investigação buscou elucidar quais as possíveis compatibilidades ou incompatibilidades qualitativas e/ou quantitativas decorrentes das relações estabelecidas entre as demandas por mão de obra qualificada e os modelos de formação profissional historicamente constituídos pelos SENAI/ES, tendo em vista os paradigmas de produção industrial existentes no Espírito Santo.” (LIMA, 2007, p.12).

\footnotetext{
${ }^{*}$ DOI - 10.29388/978-85-53111-86-2-f.149-166

${ }^{1}$ LIMA, Marcelo. A História da formação profissional: os passos e descompassos históricos do SENAI-ES com os paradigmas da produção no Espírito Santo - 1948/1999. Vitória: O Autor, 2007. Este texto foi desenvolvido como parte do Projeto de Pesquisa CIAVATTA (2012).,
} 
Além disso, a historicidade de sua obra, ou seja, a demarcação do espaço e do tempo utilizados, deixa claro, já na introdução, o objetivo do autor: mostrar a contradição, categoria central utilizada na análise, que permeia a história do SENAI no Espírito Santo, principalmente na relação entre oportunidade de inserção social e ocupacional para jovens capixabas e os interesses das empresas capitalistas. Esta contradição pode ser identificada como a contradição principal do fenômeno analisado pelo autor no bojo do pensamento de Mao Tsé-Tung que, em sua obra "Sobre a Contradição", argumenta que "todo processo tem, necessariamente, uma contradição principal, cuja existência e o desenvolvimento determinam a existência e o desenvolvimento das demais contradições ou agem sobre elas" (TSÉ-TUNG, 2001, p.70).

No Espírito Santo a instituição está presente desde o ano de 1948. O SENAI completou 56 anos de existência em 1999, ano em que autor defendeu a sua dissertação de mestrado na UFES, e que deu origem ao referido livro. Marcelo Lima destaca, ainda, a diversidade de cursos que o SENAI/ES vem abarcando desde sua criação enquanto entidade paraestatal, partindo da marcenaria à mecatrônica, da panificação à robótica; compreendendo cursos que atendem o $1^{\circ}$ e o $2^{\circ}$ segmentos do ensino fundamental.

\section{Fontes de pesquisa}

As fontes se fazem importantes para conferir historicidade ao texto. Dessa maneira, Marcelo Lima é bem explícito sobre o uso que fará delas logo em sua introdução. $\mathrm{O}$ autor escreve que utilizará a análise documental, entrevistas, formulários, relatórios anuais, fotografias e anúncios de jornal.

Para análise documental, o autor realizou um levantamento histórico e estatístico dos indicadores socioeconômicos que tratam da implantação e funcionamento da atividade industrial a partir de 1940. Entrevistou 32 pessoas envolvidas no ensino, na gerência e/ou no aprendizado do SENAI/ES, sendo 11 instrutores, 8 diretores de escola, 2 coordenadores, 2 supervisoras de estágio, 1 supervisor da área de Eletricidade, 1 secretário de escola, 1 diretor de formação profissional, 1 orientadora educacional, 2 diretores regionais, 3 presidentes da FINDES (Federação das Indústrias do Espírito Santo), 1 ex-representante do MEC (Ministério da Educação e Cultura) no Conselho Deliberativo do SENAI, ex-diretor-chefe de Recursos Humanos da CRVD (Companhia Vale do Rio Doce), 1 ex-professor dos cursos técnico-tayloristas (TWI).

Realizou também onze entrevistas com os gerentes de manutenção da CVRD, da Aracruz Celulose, da Samarco Mineração, da Cimento Paraíso, da Carboindustrial, da Flexibras, da Fibrasa, da Garoto, da Poltex, da Metalúrgica União e da CST (Companhia Siderúrgica de Tubarão).

Além das fontes já citadas, 235 trabalhadores egressos do SENAI/ES e inseridos nas empresas já citadas, como por exemplo a CST, e Eluma Cone- 
xões forneceram contrapontos e subsídios complementares aos dados gerais da pesquisa através do preenchimento de formulário.

Relatórios anuais de atividades do SENAI/ES de 1955 a 1997 também foram analisados: cursos oferecidos, matrículas, carga horária, número de escolas, programas, metodologia de ensino, currículos, materiais didáticos e roteiros de trabalho para percorrer as principais mudanças na formação profissional no Espírito Santo.

Fotografias antigas, usadas como ilustração da realidade da formação profissional no Espírito Santo, bem como a seleção de anúncios do jornal A Gazeta dos anos 1971, 1984, 1994 e 1998, pelos quais analisou os requisitos de qualificação profissional e de escolaridade exigidos pelos empregadores para cada período levantado, organizando-os em tabelas.

\section{O livro e suas categorias de análise}

Logo no primeiro capítulo o autor estabelece sua escolha teóricometodológica. Marcelo Lima faz uma análise marxista do tema e, para isso, expõe os conceitos e as categorias que serão utilizadas por ele ao longo do livro. Para explicar Marx, apropria-se de seu antecessor Hegel e de seu oposto Feuerbach. O que o autor pretende e faz com propriedade, neste capítulo, é explicar a relação dialética entre Trabalho e Educação e expor os conceitos básicos de sua fundamentação teórico-metodológica.

Destacam-se os conceitos de concreto e abstrato, concreto espiritual (Hegel), concreto sensível (Feuerbach) e concreto pensado (Marx), múltiplas determinações, totalidade, mediação, contradição, essência e aparência. Para fins metodológicos, neste trabalho enfatizaremos as categorias mediação, contradição, trabalho. Ao longo do livro, ao apresentar a História da Formação Profissional no SENAI, pudemos reconhecer algumas categorias específicas ao tema tratado. Delas, neste texto, selecionamos Trabalho-Educação, historicidade de Trabalho-Educação, formação profissional, mudanças econômicas e educacionais, formação geral e formação profissional e requalificação profissional dos trabalhadores.

\subsection{Totalidade, mediação e contradição}

Lima ressalta a historicidade no tratamento do tema, situando os acontecimentos no tempo-espaço de sua realização. Explicita, especialmente, as categorias totalidade, mediação e contradição. As mediações são categorias de base para a compreensão da totalidade na relação parte/todo, evitando que se caia em abstrações ou em empiricismos - embora não faça uso deste termo, 
tem em vista não ficar preso a relações mecanicistas. Para isso, apropria-se da dialética materialista.

Nesta concepção dialética da realidade, mediação não se confunde com meio, termo próprio à área de comunicação (meios audiovisuais, mídias sociais etc.). CIAVATTA (2014) sinaliza "a importância dos meios, dos objetos para alcançar determinado conhecimento. De outra parte, aparentemente, simplifica-se o seu papel mediador ao concebê-los como meios" (p. 222). Este é o mundo das aparências, do conhecimento imediato.

Mas os processos sociais, incluindo os meios de comunicação, são mais complexos, como expõe Marx com o exemplo da população, ponto de partida e ponto de chegada, quando superamos a abstração, a convenção da língua, inerente a toda palavra, e alcançamos o fenômeno expresso por ela, um grande conjunto de pessoas de algum tempo e lugar, "síntese de múltiplas determinações". (MARX, 1977, p. 229). Estamos assim, no campo das mediações, dos processos sociais complexos que constituem, a totalidade social de determinada população nos seus aspectos físicos, econômicos, culturais etc. (a população brasileira, a portuguesa, a carioca etc.).

Sobre a contradição, Mao Tsé-tung (2001), na história do conhecimento existem duas concepções de mundo opostas: a metafísica e a dialética. A primeira, própria do idealismo, considera os fenômenos isoladamente e acaba por explicar os fenômenos sociais a partir de condições exteriores a eles. Ao contrário da concepção dialética que busca entender o movimento dos fenômenos a partir de suas contradições internas, concebendo as causas externas como a condição das modificações. Assim, na esteira do pensamento marxiano, que concebe a contradição fundamental da sociedade capitalista como o caráter social da produção, em um polo, e o caráter privado da propriedade no outro polo, Marcelo Lima procura entender as particularidades do fenômeno capixaba de formação profissional. no SENAI.

Para isso, utiliza a "subtotalidade" trabalho-educação enquanto parte de uma totalidade ampla, homem/educação/trabalho/natureza), à qual o autor dedicará. Seu trabalho estabelece uma relação de modelação recíproca "pela qual política econômica que (que constitui uma realidade em que ocorre um tipo de trabalho) e política de educação (que constitui um tipo de educação denominado formação profissional) se orientam, ou podem orientar-se mutuamente". O autor utiliza a metáfora do barro que é modelado pela mão humana, mas também ela se modela por ele, constituindo uma totalidade social que vai variar de acordo com a materialidade histórica (tempo-espaço) na qual está inserida (LIMA, 2007, p. 25-26), grifo do autor). 


\title{
2.2 Trabalho-Educação
}

\author{
Lima destaca:
}

Ou seja, partimos do pressuposto de que há na relação trabalho e educação, no Brasil, determinações dinâmicas e recíprocas que, conforme o momento histórico, se mostram por vezes sincrônicas, mas, na maioria das vezes, anacrônicas ou no mínimo, defasadas, nas quais os modelos e os ciclos formativos e os modelos produtivos e os ciclos produtivos, embora se influenciem mutuamente, poucas vezes coincidem, seja qualitativamente seja quantitativamente. (idem, p.26).

Ainda no primeiro capítulo, com base em Lukács, concebe o trabalho como uma mediação fundamental no processo de "hominização", desenvolvendo ontologicamente o ser humano que, através do trabalho, relaciona-se com a natureza e seu meio social, dando forma a produtos e produzindo a si mesmo. Mas não somente, produzindo também as relações às quais atribuirá finalidades orientadoras de suas atividades. A partir disso, apropria-se de suas próprias realizações, agindo como sujeito cognoscente (id., p. 26-28).:

A atividade humana transcende o aspecto subjetivo e ideal quando o sujeito prático transforma algo material, exterior a ele. Quando isso ocorre, o campo subjetivo do sujeito integra-se e realiza-se num processo objetivo, caso em que ocorre a práxis: ‘[...] união indissolúvel de uma consciência (que projeta ou modela idealmente) com a mão (que opera e plasma o projetado numa matéria prima)'." (VÁSQUES apud LIMA, 2007, p.28).

O autor vem realizando um debate teórico acerca da produção humana e social do conhecimento, tributária do desenvolvimento histórico das sociedades que, em função da divisão social do trabalho e mesmo sendo um determinado saber alicerçado naquela produção, se torna cada vez mais fragmentado. Essa situação se agrava a partir das inovações tecnológicas e produtivas às quais acrescentaríamos também organizativas - realizadas pelo modo de produção capitalista. Esses dados possuem repercussões significativas na formação ontológica do ser. Para o autor,

Em outros termos, a perda do controle da forma, da composição, da densidade e da temporalidade do saber em uso na produção pode ser traduzida pela perda de controle sobre o próprio trabalho e sobre o próprio movimento de formação do ser do indivíduo. (id., p.31). 


\subsection{Historicidade de Trabalho-Educação}

Depois de uma explanação teórica, o autor utiliza a história, expressa nas suas múltiplas mediações, para provar sua tese no capítulo II. Para Lima,

[...] o ensino do 'fazer' carregou-se negativamente, igualando seu status ao das classes às quais era destinado, denegrindo de tal forma esse 'saber' a ponto de negá-lo, transformando essa pedagogia, que passou a ser feita e principalmente entendida sob a égide da organização racional do trabalho, numa espécie de 'não-saber', de educação para as mãos e não para a cabeça, de algo simples, menor e alienante. (id., p.39).

O paralelo realizado por Marcelo Lima é que a concepção pedagógica do aprender fazendo foi depreciada em função da divisão social do trabalho, que incorre na perspectiva dicotômica entre um "saber para as mãos e não para a cabeça". Ao saber reduzido ao trabalho das mãos, atribui-lhe menor valor e menor prestígio, tornando-a uma concepção "inútil" à educação propedêutica, concepção que, para o autor, é inverossímil. De acordo com sua argumentação, essa conceituação é simplificadora e é isso que ele tenta provar ao longo do capítulo e, de certa maneira, ao longo da obra ${ }^{2}$.

Frigotto (1983) ajuda a refletir sobre a diferenciação entre o "saber para as mãos" e o "saber para a cabeça" e a depreciação do primeiro em relação ao segundo. $\mathrm{O}$ autor chama a atenção para a concepção de trabalho sobre a qual se baseia a prática pedagógica da formação profissional. Trata-se de uma concepção ideológica da categoria trabalho, que tem sua significação reduzida a uma relação espúria, na qual,

O trabalho nas relações pedagógicas da formação profissional de tipo SENAI/SENAR, aparece sob especificação histórica em que foram dissolvidas as relações sociais de produção da existência onde o homem trabalhador é um proprietário e o proprietário trabalha. (p.39-40).

Perde-se a dimensão do trabalho que se constitui através da relação interativa do homem com a natureza em que ele a transforma e também modifica a sua própria natureza. Esses aspectos ficam subsumidos às demandas da formação de mão de obra qualificada. O trabalho só é valorizado quando está intelectivamente direcionado aos interesses do capitalista, e não à produção dos bens necessários à manutenção de sua vida. Neste sentido, o

\footnotetext{
${ }^{2}$ Celso Suckow da Fonseca (1986) em sua História do Ensino Industrial, também estudado nesta coletânea, mostra como o trabalho escravo restringiu o trabalho artesanal aos negros escravizados, marcando a sociedade brasileira e sua educação com preconceito e desprezo pelas atividades manuais e por aqueles que as executam.
} 
trabalho é valorizado enquanto mercadoria. Há a depreciação entre os dois tipos de saberes. Escreve Frigotto:

Em suma, trabalho que é a ação dirigida com o fim de criar bens úteis, valores de uso, forma de apropriar-se dos elementos da natureza para satisfazer necessidades humanas, condição do intercâmbio entre homem e natureza, condição do próprio devir humano - aparece sob a determinação social e histórica do trabalho abstrato, um trabalho separado dos sujeitos - força de trabalho, mercadoria. (id., p.40).

Lima vai ao século XVII para mostrar que no artesanato a pedagogia de ensinar a fazer fazendo era natural devido à falta de textos escritos. No caso brasileiro, para o autor, "a pouca expressão do trabalho artesanal e a longa duração do trabalho escravo impediram a constituição de uma tradição pedagógica desse tipo" (id., p.40). Essa perspectiva pedagógica só entra no Brasil na virada do século XIX para o XX durante o processo de desenvolvimento industrial que coincide com a passagem do Império para a República. Mas, para chegar a isso, o autor reconstitui a história do ensino industrial no Brasil desde a Colônia até a República, marcando temporalmente os momentos que ele recorta.

Uma mediação importante nessa reconstituição histórica é o ensino ferroviário que Lima utiliza como marco na divisão dos períodos da evolução histórica do ensino profissional no Brasil. Ao longo de sua argumentação, ele demonstra como o ensino ferroviário influenciou diretamente na metodologia de ensino utilizada pelo SENAI, último assunto tratado no capítulo.

A metodologia de ensino do SENAI que se delineou, segundo sua linha de argumentação, pelos decretos que se seguiram após sua criação. Neste movimento, destaca a adoção, pelo SENAI, da metodologia de aprendizagem formulada por Della Voz, diretor da Escola Imperial de Estradas de Ferro de Moscou, que no Brasil ficou conhecida como SMOs (Séries Metódicas Ocupacionais) ${ }^{3}$.

Lima explica a metodologia e faz um histórico de como ela chegou ao Brasil e ao SENAI. Tudo isso para corroborar sua tese de que o modelo pedagógico profissional adotado nesta instituição pode mostrar elementos contraditórios que possibilitam ao educando ir além dos aspectos negativos estudados por outros autores, como Ferreira ${ }^{4}$ que diz que:

\footnotetext{
${ }^{3}$ As Séries Metódicas Ocupacionais se caracterizam por uma seriação a partir do progressivo nível de dificuldade de uma determinada tarefa de uma etapa da produção na qual, através de um planejamento prévio, o aprendiz aprendia a executá-la com perfeição, alcançando-a pela repetição (LIMA, 2007, p. 46-50).

${ }^{4}$ FERREIRA, M. O SENAI e o paradigma do trabalho pós-fordista: horizontes de uma formação a serviço do capital. 1995. 270 f. Dissertação (Mestrado em Educação) - Faculdade de Educação, Universidade Federal do Ceará, Fortaleza, 1995.
} 
[...] a verdadeira preocupação do SENAI e dos empresários é tornar os indivíduos aptos para desenvolver as atividades requisitadas pelo capital na realização dos lucros, necessitando, para tanto, reduzir ou adulterar o verdadeiro sentido da educação. (FERREIRA apud LIMA, 2007, p. 49)

Mas Marcelo Lima assinala a contradição neste processo produtivo disciplinador:

[...] à medida que executam as tarefas previstas nas SMOs e se apropriam dos procedimentos usuais, os educandos podem superar os conteúdos e estabelecer, no processo produtivo ou mesmo no ambiente educacional, novas formas de realizar o trabalho, que levem em consideração sua subjetividade, anseios e capacidade de realização. (LIMA, 2007, p.50)

Mas o autor afirma que, embora o sujeito possa encontrar uma saída para a superação da sua condição "alienada", dada por uma formação mecanicista, o SENAI/ES tem uma linha de trabalho bem delineada: o atendimento das necessidades do setor produtivo industrial, evidenciando, a contradição na instituição capixaba.

Assim, podemos observar no texto de Marcelo Lima a categoria contradição como básica na estruturação de sua argumentação sobre a atuação do SENAI na formação de mão-de-obra no Espírito Santo, e a categoria mediação quando caracteriza as relações e as conjunturas históricas nos diferentes momentos que atravessam o SENAI, incidindo direta e indiretamente em suas propostas de formação profissional.

\subsection{Formação profissional}

O termo formação profissional foi o usual nas instituições destinadas à preparação para o trabalho. Somente a partir da LDB n. 9.394 de 1996, introduziu-se o termo educação profissional, nem sempre, até hoje, assimilado na prática dos trabalhadores.

O capítulo III é reservado para uma recuperação histórica das demandas por formação profissional no Espírito Santo que se deu a partir do Consenso de Washington (1989). O acordo garantiu a criação da Companhia Vale do Rio Doce e o início do processo de transporte de minério pelas estradas de ferro Vitória-Minas. Essa mudança exigiu mão-de-obra qualificada para fabricação e reparação de vagões e locomotivas. Isso possibilitou, segundo Lima, a primeira experiência no campo da formação profissional no estado. Além disso, a instalação de importantes indústrias de aço, minério pelotizado e celulose no Espírito Santo também possibilitou a ampliação das demandas por formação profissional no estado. Nesse sentido, o desenvolvimento das forças pro- 
dutivas dá forma a diferentes demandas por força de trabalho, "contribuindo" para o surgimento de novas profissões ou para seu desaparecimento, dando relevo a essas contradições.

Para ilustrar a demanda de mão de obra no Estado o autor recorre a dados do Departamento Estadual de Estatística (DEE) e aos almanaques de pessoal da Companhia Vale do Rio Doce, nos quais analisa o crescente quadro de trabalhadores com qualificação (artífices, carpinteiros, auxiliares de artífices, eletricistas, marceneiros, mecânicos, retificadores, torneiros, por exemplo).

A partir da década de 1970, houve uma polarização da mão de obra, isto é, das atividades que necessitavam de força de trabalho manual qualificada, em relação à formação de técnicos especialistas e de terceiro grau. Esta demanda sofreu significativo aumento, face à ampliação do parque industrial capixaba, com a implantação de novas fábricas, tais como a da mineradora Samarco (1977), a cerveja Antártica (1978) e a entrada em operação da Companhia Siderúrgica de Tubarão (CST) (1983). Entretanto, a partir da década de 1980, o maior empregador responsável pelo aumento da população economicamente ativa (PEA) capixaba foi o comércio (LIMA, 2007, p. 62-66).

\subsection{Mudanças econômicas e educacionais}

No capítulo IV, o assunto principal é o SENAI/ES propriamente dito. Para o autor, embora, como já dito anteriormente, o SENAI possibilitasse aprendizados positivos aos alunos trabalhadores, a raiz da formação profissional no Brasil está nos objetivos correcionais e assistencialistas do ensino industrial, que perpassa a história até os anos 1940. Mais uma vez a categoria contradição se torna essencial para entender a argumentação de Marcelo Lima.

O SENAI/ES foi criado sob o manto da Companhia Vale do Rio Doce (CVRD), cujas primeiras atividades de ensino foram realizadas na a Escola Ferroviária João Neiva em 1948, antes de sua criação oficial em 1952 sob a forma de Delegacia do Departamento Regional do Rio de Janeiro. Neste mesmo ano inaugurou sua primeira Escola de Aprendizagem, a Pedro Nolasco, fato que marca também um momento de transição para abertura de escolas maiores, os Centros de Formação Profissional.

Lima escreve a linha do tempo da história do SENAI/ES. O recorte é feito a partir da inclusão e da retirada da Educação Geral: de 1948, ano de sua criação, a 1972. A aprendizagem era monotécnica, com ênfase nos menores de idade: "a ênfase no menor aprendiz permitia certa precocidade na formação dos futuros profissionais e vinculava-se aos interesses de um adestramento contínuo, útil e produtivo". Cabe observar o caráter de terminalidade da formação monotécnica, cuja escolaridade final concedida ao educando era a de, no máximo, a $6^{a}$ série do ensino fundamental (LIMA, 2007, p. 74).

De 1972 a 1980, quando o SENAI/ES assume um modelo "multitécnico com educação geral" 
[...] passou a fornecer aos alunos que ingressavam em suas escolas o ensino supletivo de quinta a oitava série, dando um salto de qualidade enorme, integrando o ensino profissional e a educação geral que, embora "supletivada", apontava novas perspectivas de continuidade e de formação para além dos interesses imediatos da produção. (LIMA, 2007, p. 79).

No período de 1972 a 1980 houve ampliação da "escolarização" do SENAI/ES, nas unidades de ensino aprendizagem. A escolaridade mínima exigida do educando ingressante na instituição era de $4^{a}$ série do ensino fundamental, e a escolaridade final obtida pelo mesmo era a de $8^{a}$ série do mesmo nível. A nomenclatura do curso sofreu alteração. Alterou-se de Curso de Aprendiz de Ofício (CAO) para Curso de Aprendizagem Industrial (CAI).

$\mathrm{Na}$ década de 1980, o processo de expansão das escolas, das unidades de ensino do SENAI/ES continuou. Expansão essa que, após 1982, admitiu a existência de uma rede de escolas duais, isto é, unidades que ofertavam a aprendizagem concomitante ao ensino propedêutico, em modalidade supletiva. Por outro lado, havia unidades que ofertavam somente a aprendizagem, sem garantia de elevação da escolaridade, como tradicionalmente realizava o SENAI/ES, com escolaridade e idade mínima, respectivamente, de $4^{\mathrm{a}}$ série primária e 14 anos de idade para ingresso na instituição.

No decorrer da redação de Marcelo Lima fica evidenciado como o SENAI/ ES, ao longo de seu desenvolvimento, vai se alinhando progressivamente aos interesses e às demandas do mercado, inclusive na estrutura e na organização pedagógica. Lima escreve:

Ao que parece, a partir daí a relação custo qualidade da Formação Profissional começou a ser reavaliada por objetivos mais economicistas que educacionais, numa perspectiva mais de curto do que de longo prazo. (LIMA, 2007, p. 86)

Assim, a década de 1980 é um marco, pois ocorre o fim da oferta obrigatória da educação técnica e profissionalizante no Brasil, ${ }^{5}$ passando a existir dois modelos no SENAI/ES: educação técnica e profissional com formação geral e outra somente com a formação profissional. Contudo, sabese que essa cisão não se deu pura e simplesmente pelas injunções do mercado, mas também como expressão das pressões sociais em função do imaginário ainda nutrido pela sociedade, acerca de uma hierarquia que reflete uma construção histórico-social, da educação, nos termos de Lima, uma "para cabeça" e outra para "as mãos", sendo a primeira a mais valorizada. Ressalta-

\footnotetext{
${ }^{5}$ A referência ao fim da obrigatoriedade da profissionalização, nos termos da Lei n. 5.692/ de 1971, é a lei n. 7.044 de 1982 que a tornou opcional "a critério dos estabelecimentos de ensino" (Art. $1^{\circ}$., par. $2^{\circ}$.).
} 
se também a categoria mediação expressa indiretamente, no desenvolver do texto, podendo ser lida em seu movimento discursivo, destacando os fatos não apenas como fatos isolados, mas relacionados a uma estrutura maior, a totalidade social a que pertencem.

Neste contexto, sobretudo a partir de 1982, além das disputas políticas que existiam acerca das possíveis cidades capixabas que poderiam vir a ter uma unidade do SENAI, existiam disputas pelas perspectivas e objetivos que o SENAI deveria assumir no que diz respeito à formação do sujeito. Para provar isso, Marcelo Lima utiliza entrevistas.

Com essa escolha, emerge a necessidade de abrir um espaço de discussão sobre a História Oral, campo recente e bastante polêmico na História. A polêmica gira em torno da pergunta: onde se encaixa a História Oral? Ela é uma técnica, uma disciplina ou uma metodologia?

Os teóricos que defendem este campo como técnica só enxergam sua função enquanto conservação de acervo. Já os que veem a História Oral como disciplina defendem que ela inaugurou técnicas específicas de pesquisa, procedimentos metodológicos singulares e um conjunto próprio de conceitos. Os que a enxergam como metodologia argumentam que ela estabelece e ordena os procedimentos de trabalho, assim como formula perguntas. Entretanto, ela não é capaz de respondê-las, cabendo à Teoria da História solucionar esta problemática.

$\mathrm{Na}$ apresentação do livro Usos \& Abusos da História Oral, as organizadoras Marieta de Moraes Ferreira e Janaína Amado (2006) debatem essas questões. Além disso, se posicionam fortemente quando escrevem: "Entendida como metodologia, a história oral remete a uma dimensão técnica e a uma dimensão teórica. Esta última evidentemente a transcende e concerne à disciplina histórica como um todo." (p. viii, 2006.)

Pelo que pudemos observar, Marcelo Lima também adota a escolha pela História Oral como metodologia, principalmente com o uso de entrevistas para corroborar, ou não, sua hipótese sobre a oferta de formação geral pelo SENAI/ES: de acordo com suas entrevistas, há setores, nos quais se incluem ex-gestores, ex-funcionários, bem como gestores e funcionários ainda atuantes na instituição, que defendem a formação geral como algo muito positivo para a formação do sujeito trabalhador. Já, outros setores, justificam que a formação escolar é dever do Estado e que, em função dos altos gastos que a formação profissional demanda, caberia ao SENAI/ES a sua função "precípua”, formar para a indústria.

Neste sentido, Lima transcreve trecho da entrevista que realizou com ZRS, representante do MEC no Conselho Regional do SENAI: 
"De acordo com ZRS [...] a forma de trabalho do Civit ${ }^{6}$ tinha uma conotação muito mais grave":

O que justifica a escola do Civit sem Educação Geral é uma tentativa do empresariado em dar um caráter de terminalidade à Formação Profissional, e dispor dessa mão de obra sem uma consciência crítica. $\mathrm{O}$ empresariado tem interesse naquela mão-de-obra que atenda aos seus interesses. Como um empresário vai admitir alguém que está cursando Mecânica Geral aspirando ser um engenheiro. (LIMA, 2007, p.87).

\subsection{Formação geral e formação profissional}

O que verificou na década de 1980 foi o esfacelamento dos cursos com formação geral e a gradual prevalência dos cursos de curta duração em detrimento dos cursos de aprendizagem. A partir da década de 1990 esse movimento fica ainda mais delineado, conforme Lima ilustra com dados estatísticos:

Os cursos de aprendizagem registraram 585 matrículas, em 1985, e 799, em 1991, mas as matrículas em cursos de curta e média duração passaram de 10.145, em 1985, para 16.169, em 1991, o que não destituiu a aprendizagem como modelo predominante, mas continuou a mostrar como o SENAI começava a reconhecer também a importância do treinamento e da qualificação. (LIMA, 2007, p. 90-92)

De 1992 a 1994, quando começou a ocorrer mudanças motivadas pela busca da redução de custos, houve queda na quantidade e na permanência dos alunos e, a escola passou de gratuita a paga, de pública a privada. De 1994 a 1999, quando o SENAI, buscando aumentar sua receita, acelerou o crescimento dos cursos, promoveu a extinção ou diminuição dos cursos de maior custo e de longa duração. Mudou também o perfil de seu público, posto que, com o fim da educação geral, a escolaridade mínima exigida para ingresso no SENAI aumentou. Este fato não representou ganhos qualitativos no que diz respeito à qualidade dos cursos e da formação do sujeito.

Ao longo de toda sua argumentação, Marcelo Lima se preocupa em deixar no horizonte o objetivo do empresariado quanto à formação profissional: o objetivo econômico, a busca pelo lucro. Nesse sentido, a década de 1990 é sintomática, pois pari passu ao processo nacional, o SENAI/ES se reestrutura e se volta para as novas demandas do mercado.

O modelo de ensino muda o foco: antes, visava a aprendizagem de jovens trabalhadores que buscavam seu espaço no mercado; passou a visar a qualificação e o treinamento do operário já empregado. Esse buscava, principalmente, novas qualificações, objetivando maior inserção em outros setores

\footnotetext{
${ }^{6}$ Centro Industrial de Vitória.
} 
produtivos das indústrias, tornando-se polivalente e mais atraente para o empregador. É nesse momento de análise que Lima também enxerga outra contradição: a valorização do trabalho versus a desvalorização do trabalhador:

Por um lado, exige-se mais preparação científica e técnica para a execução de um trabalho; por outro, desvalorizam-se, precarizam-se as conquistas dos trabalhadores, aumentando o valor do que é produzido, sem que isso represente, na mesma proporção, a valorização daquele que produz. (Lima, 2007, p. 184)

Ciavatta (2015) contribui para pensarmos a contradição posta entre a valorização do trabalho e a desvalorização do trabalhador analisada por Lima. A autora aponta a coexistência de duas lógicas: a lógica da produção e lógica da educação. A primeira é pautada pelas necessidades de lucro, pelo curto tempo necessário à produção e o aumento da mesma, pela "mercantilização de toda atividade humana". A segunda, preza a formação do sujeito, "o tempo médio e longo da aprendizagem, a humanização, e a emancipação das amarras da opressão" (p. 27).

O SENAI/ES passou a priorizar os cursos de curta duração visando a redução de custos e o aligeiramento da formação em razão da implementação de políticas neoliberais de reestruturação produtiva no Brasil. Dessa maneira, mais uma vez, a instituição capixaba se adequou aos interesses industriais do estado, e prevaleceu a lógica da produção. Para esse movimento, modificou-se o público-alvo que, antes, era composto por jovens que visavam a entrada na indústria. O SENAI buscava requalificar os trabalhadores já inseridos nessa lógica, pois as políticas neoliberais exigiam maior qualificação e, contraditoriamente, depreciava os salários.

Em meio a esse processo, pelo qual o SENAI/ES passou, existiram tensões entre os interesses dos industriais, empresários e a "demanda" por formação integral, formação geral; entre aquilo que o mercado exigia ou não; entre uma percepção e visão a longo prazo e a satisfação das necessidades do mercado a curto prazo, ou seja, um acirramento das contradições entre capital e trabalho.

\subsection{Requalificação profissional dos trabalhadores}

Marcelo Lima realiza o aprofundamento do debate sobre educação geral e formação e/ou educação profissional e suas relações, a partir de entrevistas com empresários, membros e ex-membros do SENAI. No bojo de toda a problemática descrita, nas transcrições que Lima (2007, p. 111-118) realiza em seu livro, acerca da percepção dos sujeitos envolvidos no processo de implementação da educação geral e da sua posterior retirada, avaliamos que há um acirramento das opiniões entre os envolvidos no processo. Contudo, existe uma perspectiva muito positiva do período em que existia a formação geral, 
principalmente dos instrutores que ainda atuavam nas instituições do SENAI/ ES, sinalizando uma série de pontos positivos da educação geral no processo da aprendizagem profissional. Também pudemos verificar essa visão em uma parte significativa de dirigentes e ex-dirigentes.

O capítulo $\mathrm{V}$ é dedicado para análise dos pré-requisitos de emprego explicitados nos anúncios de jornal. Marcelo Lima mantém, de acordo com a metodologia descrita no primeiro capítulo, as quatro datas: 1971, 1984, 1994 e 1998. Ele apresenta os resultados obtidos por meio de tabelas e, a partir delas, tira suas conclusões.

Em 1971, por exemplo, o SENAI ainda não era referencial de ingresso no trabalho industrial. Já em 1984, o curso do SENAI era visto como diferencial na hora da contratação. $\mathrm{O}$ autor não consegue comprovar sua hipótese inicial de que já haveria, no início dos anos 1990, uma sofisticação dos requisitos exigidos para inserção no trabalho industrial, pois, segundo ele, os anúncios de jornal de 1994 não revelaram isso. Mas os jornais de 1998 mostram os sinais do novo paradigma de produção, porém, em locus privilegiado, as empresas de grande e médio porte voltadas para o mercado externo.

No capítulo VI, Marcelo Lima aprofunda o olhar sobre o novo paradigma de produção, a partir de entrevistas realizadas com gerentes de recursos humanos, de produção e de manutenção das indústrias capixabas, tais como Chocolates Garoto e Vale do Rio Doce. O autor destaca o processo de requalificação em que o profissional tende a aglutinar funções e a se apropriar de funções, a partir da formação de equipes multidisciplinares, nos vários segmentos industriais e, a partir de cursos internos promovidos pelas próprias indústrias, com a finalidade, também, de reduzir tempo e custos sobre as necessidades e demandas da produção.

$\mathrm{Na}$ década de 1990 ocorrem mudanças que já vinham sendo apontadas pelos funcionários, ex-funcionários, dirigentes e ex-dirigentes de instituições como a FINDES (Federação das Indústrias do Espírito Santo), por exemplo, destacando a revalorização dos profissionais com maior nível de escolaridade, sobretudo o $2^{\circ}$ grau técnico. Essa revalorização era parte do processo de reestruturação produtiva e da modernização das tecnologias das plantas industriais do Espírito Santo, bem como de novos métodos gerenciais e organizacionais da produção. Rompia-se, assim, em significativa medida, com o modelo taylorista, exigindo maior capacidade criativa, autonomia do trabalhador e desenvoltura na resolução de problemas.

O autor notou, ainda, a busca de requalificação profissional dos trabalhadores associada à formação técnica e, também, ao aumento do nível de escolaridade dos mesmos, incentivados, pelas próprias empresas. Neste sentido, vemos que a educação é uma mediação de desenvolvimento de um trabalhador polivalente, que se adapte melhor às novas exigências dos círculos de qualidade, da produção e às novas tecnologias advindas da modernização gradual 
que vinha ocorrendo no parque industrial capixaba, sobretudo nas indústrias direcionadas ao mercado externo.

Esse processo era parte de um movimento que se integrava aos novos paradigmas da produção em escala mundial, não limitada ao Espírito Santo. Além de tornar os trabalhadores mais "adaptáveis" às novas condições que se apresentavam, tinham em vista atingir as exigências de qualidade e, assim, as certificações como, por exemplo, a ISO 9000 e a do PRODFOR (Programa Integrado de Desenvolvimento e Qualificação de Fornecedores) ${ }^{7}$.

No bojo das necessidades e demandas da produção industrial sob forte impacto da reestruturação, destaca-se a polivalência, o processo de terceirização e quarteirização dos serviços para a aceleração do processo produtivo, enxugamento do quadro de operários para prover a redução de custos. Neste contexto, ressalta a gradual extinção de postos de trabalho historicamente formados pelo SENAI/ES em decorrência do desenvolvimento das forças produtivas (LIMA, 2007, p. 150-155).

Um processo observável, ainda hoje, é a exigência de maior qualificação e de formação técnica para a inserção nas indústrias. Esse dado, observa o autor, está gerando uma depreciação dos cursos oferecidos pela SENAI/ES, bem como a depreciação dos salários. Isso ocorre na medida em que a força de trabalho passa a ser nivelada "por cima", mesmo que as atividades desenvolvidas não exijam grande conhecimento teórico da função, fato que gera uma pressão negativa sobre os salários.

Deste modo, técnicos e tecnólogos são contratados e têm suas carteiras de trabalho assinadas como "técnicos de manutenção", postos de trabalho, anteriormente, ocupados por profissionais formados pelo SENAI/ES.

Assim, Lima conclui que

[...] em toda sua história, o SENAI esteve a serviço dos interesses empresariais nacionais, em particular os dos capixabas. No entanto, os modelos constituídos e historicamente praticados foram mediados por outros interesses e estratégias, que forneceram diferentes níveis de qualidade e abrangência aos serviços de Formação Profissional prestados pela Instituição à sociedade capixaba. Contudo, à proporção que a Instituição foi perdendo a mediação de interesses sociais e humanísticos na realização de seus objetivos mais fundamentais, os dos empresários, ela

\footnotetext{
7 "O Programa Integrado de Desenvolvimento e Qualificação de Fornecedores (PRODFOR) nasceu em 1997 com o objetivo de desenvolver e qualificar os fornecedores de bens e serviços das grandes empresas estabelecidas no Espírito Santo, garantindo a qualidade das atividades e produtos oferecidos". Disponível em: <http://www.iel-es.org.br/consultorias-e-solucoesempresariais/prodfor/>. Acesso em: 07 jan. 2017.
} 
foi perdendo sua capacidade de enxergar mais longe, rendendo-se ao imediatismo e ao economicismo, podendo ter comprometido sua eficiência pedagógica e didática. (LIMA, 2007, p.192).

Ao identificar os interesses empresariais como orientadores da história do SENAI, Marcelo Lima desvela o polo principal da contradição principal por ele analisada. De acordo com Tsé-tung, "dos dois polos contraditórios, um é necessariamente principal e o outro, secundário. O principal é aquele que desempenha o papel dominante na contradição. O caráter dos fenômenos é sobretudo determinado por esse polo [...]." (TSÉ-TUNG, 2001, p.73).

Assim, os interesses empresariais capitalistas acabaram por pautar a história da formação profissional capixaba e, por consequência, a brasileira. Entretanto, vale ressaltar que, de acordo com o pensamento do revolucionário chinês, os polos não são estáticos. Dadas determinadas circunstâncias, o polo principal se converte em secundário e o secundário se torna o principal. Esse movimento muda o caráter do fenômeno e carrega consigo a potência transformadora. Nesse sentido, há momentos na história do SENAI em que os polos se invertem como, por exemplo, no período entre 1972 e 1980, quando há uma preocupação com a formação geral e, portanto, com a formação mais ampla do aluno sobre os fundamentos técnicos e tecnológicos dos processos operacionais.

A pesquisa de Lima (idem) evidencia que, no processo de formação dos trabalhadores, o aumento do nível de escolaridade funciona como um indicador, como um aspecto facilitador para a absorção dos valores que o novo paradigma de produção, a partir do processo de reestruturação produtiva identificada trouxe consigo, na década de 1990. Saber ler, escrever e interpretar tornou-se um pré-requisito que, em muitos casos, segundo as declarações colhidas nas entrevistas realizadas por Marcelo Lima, é mais atrativa do que uma formação técnica rigorosa, pois seria um dado muito positivo para a adaptação e enquadramento do sujeito às demandas e necessidades da produção e das novas condições e exigências do mercado de trabalho.

\section{Considerações finais}

É possível enxergar na obra o Marcelo Lima como o pesquisador e, ao mesmo tempo, o Marcelo Lima que viveu dentro do SENAI, com experiência, tanto como aluno, quanto como professor. Verificamos grande esforço do autor em compreender a história do SENAI/ES. Nesse sentido destacamos uma categoria teórica, dentre outras que mencionaremos, reveladora da intenção do autor em realizar uma pesquisa densa. A categoria da reconstrução histórica (CIAVATTA, 2014). Ao fazer o resgate histórico dos processos, conjunturas e contextos a partir dos quais a referida instituição operou mudanças em sua oferta formativa de trabalhadores, revela processos sociais mais 
amplos e não unilateralmente determinados, como intrínseca de uma realidade complexa em suas múltiplas determinações. São, portanto, decorrentes da explicitação de uma temporalidade e de um lugar onde ocorreram

A diversidade de fontes utilizadas por Marcelo Lima permitiram ao autor fugir de análises fatalistas e factuais da história, situando os eventos na curta duração, não considerando-os apenas como dados que podem ser explicados por si sós, em sua mera descrição. O autor explora os múltiplos tempos que constituem os processos pelos quais o SENAI/ES passou, revelando seus sentidos, a racionalidade que os movia, bem como destacar as contradições presentes nos mesmos. Realiza uma costura entre os aspectos econômicos, históricos, sociais e culturais que compõem a totalidade que nos permite identificar as mediações que dão forma aos diferentes momentos e transformações ocorridos no SENAI/ES.

Nesse sentido, pode-se dizer que o autor em questão faz uma análise da longa duração do sistema capitalista na particularidade do estado capixaba, sendo ela importante por mudar a forma como se escreve a história, capturando os eventos não como fatos dados, mas como fruto da materialidade histórica que toma forma a partir das relações entre sujeitos históricos e suas várias formas de entender a realidade. Esse dado é crucial pois que não se pode ignorar outras áreas de conhecimento das ciências humanas para interpretar a realidade. "Cada 'atualidade' reúne movimentos de origem, de ritmo diferentes: o tempo de hoje data, ao mesmo tempo, de ontem, de anteontem, de outrora". (BRAUDEL, 1992, p. 18).

O que se quer dizer neste trecho de Ferdinand Braudel é que uma determinada realidade não pode ser compreendida e apreendida se a considerarmos de modo linear, ela é dialética. Da mesma forma, Marcelo Lima buscou escrever a história da educação profissional no Brasil, atendo-se ao SENAI/ $\mathrm{ES}$, não linearmente, e sem aderir à historiografia tradicional.

Podemos observar ao longo da redação de Marcelo Lima um dado que Karel Kosik (1976) nos auxilia a compreender, "descortinar" a realidade social e os "fenômenos históricos" a partir do materialismo dialético. De acordo com Kosik (idem), o pensamento dialético, permite-nos ir além das aparências dos fenômenos, isto é, daquilo que não é imediatamente captado pelo homem, pelo sujeito cognoscente. Distinguir entre representação e o conceito da coisa, distinguir essência da aparência para que assim se possa chegar a compreensão da realidade.

Neste processo de compreensão da realidade não se pode tomar os acontecimentos, como conceitos e abstrações, como atemporais ou categorias a priori. Deve-se situá-los no tempo e no espaço a fim de identificar em que condições eles se deram e se desenvolveram, qual a conexão deles com os fenômenos, aparência e essência, alcançando assim a realidade e a construção da verdade que está em processo. Conceber a verdade em processo, de acordo com Fontes (2014) é admitir que tendemos a ela, mas que ela jamais será ter- 
minada. As coisas não estão dadas no mundo e nem existem dotadas de um sentido próprio. Isso se torna ainda mais latente quando se trata da apropriação da natureza pelo homem, pela qual passa a construir novas relações e cria uma outra realidade, a humano-social.

Assim, Marcelo Lima escreve a história da educação profissional no Brasil objetivando desvelar as aparências e revelar as intencionalidades subjacentes às políticas educacionais, de modo que identifiquemos que não é somente a racionalidade econômica que explica as nuances e transformações operadas na educação profissional no Brasil. Existem articulações e intencionalidades que não podem ser compreendidas apenas em sua curta duração e que, em muitos casos, as aparentes contradições não operam de modo a tencionar os antagonismos de classes, e os conflitos, na realidade, fomentam a conformação dos sujeitos ao que o autor chama de "novos paradigmas de produção”. 


\title{
IX \\ HISTÓRIA DA SOCIALIZAÇÃO DA FORÇA DE TRABALHO EM SÃO PAULO (1873 - 1934) - A contribuição de Carmen Sylvia Vidigal de Moraes $^{{ }_{1}}$
}

\author{
Marcelo Lima \\ Jacqueline Botelho
}

\section{Introdução}

A autora do livro aqui analisado possui graduação em Psicologia (1973), mestrado em Educação (1978) e doutorado em Sociologia pela USP (1990). É professora titular da Faculdade de Educação da USP, com larga experiência na área de Educação, com ênfase em Educação e Trabalho, atuando principalmente nos temas da educação, educação do trabalhador, história da educação, educação profissional e políticas públicas.

O trabalho de Moraes (2003) intitulado Socializaşão da força de trabalho: instrução popular e qualificaşão profissional, elaborado no âmbito da Sociologia, realiza minuciosa reconstrução histórica da esfera do Trabalho e da Educação, situada na importante e decisiva relação espaço-tempo: no estado de São Paulo, no período de 1873 a 1934. Por meio de inúmeras fontes secundárias, mas principalmente primárias, a pesquisadora remonta aos discursos das elites paulistas, explicitados nos documentos e relatórios das instituições de ensino e / ou publicados nos jornais: "O Correio Paulistano", A Província de São Paulo" e "O Estado de São Paulo", entre outros.

O trabalho de Moraes parte de um conjunto de indagações sobre quais, como, por que, para que, com que meios e métodos operaram as iniciativas de socialização dos trabalhadores manuais no espaço-tempo referido. Sua problemática desdobra-se no desenvolvimento histórico das propostas e práticas de qualificação profissional e de instrução popular, empreendidas por lideranças empresariais e / ou governamentais e dos discursos justificadores dos administradores, docentes e reformadores das várias instituições de instrução primária e ensino profissional elencadas.

Iniciando pelo Período Imperial, a obra de Moraes chega até o primeiro governo provisório da Era Vargas, recuperando um cenário importante para a consolidação do movimento operário e da luta de classes no Brasil, o que evidenciou um processo bastante peculiar. Apesar de já possuirmos algumas fábricas em funcionamento desde a segunda metade do século XIX, especialmente nas principais cidades, até 1888 , as lutas de classes no Brasil ainda

\footnotetext{
*DOI - 10.29388/978-85-53111-86-2-f.167-180

${ }^{1}$ Este capítulo é parte da pesquisa desenvolvida no Projeto de Pesquisa (CIAVATTA, (2012).
} 
giravam em torno da questão da escravidão e, "mesmo após o fim desta, persistiram grandes obstáculos para a formação da classe trabalhadora livre, associados à diversidade da origem dos novos assalariados" (MATTOS, 2009, p.33).

Com base numa teoria da história orientada pelo conceito marxista de luta de classes, a autora apresenta uma cronologia não linear ao buscar a histo ricidade das inciativas de socialização dos trabalhadores manuais no espaço tempo referido. Coerente com a dialética marxiana, descreve o processo histórico tendo em vista as tendências de avanço e de recuo próprias do movimento da realidade. Com riqueza de dados sobre o perfil dos educandos e os tipos de cursos em cada fase, expõe a forma complexa, como a organização e a função social dos espaços escolares submeteram-se às forças de permanências e de resistências.

O texto revela as principais mudanças ocorridas nos projetos ideológicos conduzidos pelas elites, destacando as principais rupturas e inflexões sofridas pelas práticas educativas para explicar e descrever as transformações dos projetos educacionais hegemônicos em cada fase histórica. Contribui de modo bastante relevante, do ponto de vista historiográfico, para a reconstrução das fases e etapas da história da socialização da força de trabalho, elucidando e problematizando a periodização em cada passo do processo histórico.

Articulando aspectos qualitativos e quantitativos em coerência com a base material de seu objeto, a autora afirma que "o aumento do número de escolas, de cursos e de vagas nas escolas profissionais estaduais, no Liceu, nas escolas ferroviárias" e no SENAI (Serviço Nacional de Aprendizagem dos Industriários) não foi suficiente para atender as demandas da urbanização e da industrialização (MORAES, 2003, p. 430).

Preocupada com o impacto qualitativo das mudanças pedagógicas e políticas em cada fase histórica, a autora elenca as mudanças mais significativas nas instituições mais relevantes, sem perder os detalhes quantitativos que dão base a esse movimento da realidade. Conclui que apesar da busca incessante das elites, em responder aos seus interesses hegemônicos e às necessidades industriais, de formação de mão-de-obra qualificada e de constituição de um mercado de trabalho livre, ocorre vários momentos em que a oferta educativa e o desenvolvimento das forças produtivas entram em compasso, mas, sobretudo, em descompasso entre si.

Ao demonstrar a trajetória dos estabelecimentos, as visões de seus administradores, seus métodos, públicos-alvo e prática pedagógica, indica a especificidade e a singularidade de cada instituição, sem cair num determinismo exógeno ou relativismo endógeno, articulando as amplas determinações da totalidade histórica, sem se render ao localismo culturalista que dissocia as instituições do processo histórico mais amplo. Ou seja, a autora, ao abordar seu objeto, não cai em reducionismos. Desloca sua análise do singular para o universal por meio da mediação da particularidade para obter os elementos mais 
estruturantes da totalidade que explicam social e historicamente seu tema de pesquisa (KOSIK, 1976; LUKÁCS, 2010; CIAVATTA, 2014).

Moraes (2003) utiliza várias categorias de análise que servem como mediações fundamentais para a compreensão do seu objeto, quais sejam, históricas, econômicas, políticas e educacionais: trabalho livre, trabalho compulsório, luta de classe, história das instituições, função social do ensino; instrução primária, eugenia, qualificação profissional, disciplinamento, formação do trabalhador nacional e organização racional do trabalho. Nos limites deste texto, elegemos alguns eixos analíticos que constituem a estrutura do artigo.

São três os itens principais. No item 1, destacamos os Principais Eixos Analíticos e os conceitos fundantes da investigação que deram origem ao livro de Moraes. No item 2 sinalizamos os Projetos Educacionais constituídos no espaço-tempo do período pesquisado. Tais projetos tiveram como pano de fundo e determinação mais ampla A Luta de Classes e a Formação e o Controle do Mercado da Força de Trabalho que dão título ao item 3 e que explicam a totalidade histórica que envolve o objeto de pesquisa. Os itens 3.1 e 3.2, respectivamente, por sua vez, denominados Escola Quartel-Convento-Autosuficiente e Escola-Fábrica-Escola descrevem a especificidade e materialidade dos projetos educacionais produzidos pelas elites paulistas, cujas implicações ideológicas e pedagógicas são analisadas nas considerações finais.

\section{Principais eixos analíticos}

A luta de classes que envolve o processo de formação e de controle do mercado da força de trabalho é o campo da totalidade que constitui pano de fundo deste estudo. Neste contexto, movem-se dois projetos educacionais fundamentais, elaborados e implementados pelas e para as elites paulistas exercerem sua hegemonia. Um projeto que tem o formato assistencial e moralista, criou e manteve várias instituições do tipo quartel-convento-auto-suficiente (dos anos de 1870 a 1890); e o outro que estabeleceu o formato racional e psicotécnico, que criou e manteve estabelecimentos do tipo escola-fábricaescola (dos anos de 1890 a 1930).

\section{Projetos Educacionais}

Em nossa análise sobre o livro, dois períodos (1870 a 1890 e 1890 a 1930) ganham destaque diante dos processos, dados e fatos históricos apresentados. Em que pesem as interpenetrações das fases em tela e a diacronia entre as histórias das instituições de ensino, consideramos o processo histórico do Liceu de Artes e Ofícios, expressão da vanguarda pedagógica do ensino industrial em São Paulo. Encontramos um ponto de inflexão importante na periodização dos projetos educacionais das instituições de ensino, na sua articulação com as demandas de mão-de-obra. Acreditamos que um momento re- 
levante de transformação ocorre quando tem início a administração de Ramos de Azevedo no Liceu de Artes e Ofícios de São Paulo, em meados dos anos 1890.

$\mathrm{Na}$ medida em que o Liceu vai se transformando de orfanato em unidade de produção ligada ao setor da construção civil, novas bases vão se estruturando e um novo projeto educacional passa a dirigir seus objetivos e práticas educacionais. Deixará de ser um mero "depósito de crianças" para se tornar espaço de ensino profissional, formador de oficiais e contramestres, dando início, anos mais tarde, à implementação do método Della- $\operatorname{Vos}^{2}$ no contexto do formato pedagógico denominado de fábrica-escola.

Posteriormente, na gestão de Roberto Mange, esse mesmo projeto educacional vai se tornar ainda mais articulado com as demandas de qualificação de mão-de-obra para o trabalho em mecânica para empresas ferroviárias, e, posteriormente, para a incipiente indústria da época. Neste movimento, o horizonte pedagógico do liceu, com influência nas demais instituições, será o de formar operários cada vez mais especializados por meio do formato escolafábrica. A partir dos anos 1920, com a criação da Escola de Mecânica do Liceu, laboratório das inovações de Mange, o método Della-Vos já implementado desde o início do século XX por Ramos de Azevedo, vai incorporar os princípios do taylorismo e da organização racional do trabalho nos currículos e práticas de ensino profissional, cujo resultado lançará as bases para elaboração das séries metódicas ocupacionais.

Nessa lógica, o ensino profissional assume uma vertente mais industrial, em que o processo de inserção de alunos e trabalhadores vai perdendo seu caráter compulsório e passa a se orientar pela psicotécnica. Por essa orientação, tanto educandos quanto trabalhadores precisam ser formados e selecionados conforme os ditames das funções do posto de trabalho ou do destino ocupacional previamente determinado. Daí surgirão o SESP (Serviços de Seleção do Estado de São Paulo) e, posteriormente, o CEFESP (Centro de Formação e Seleção do Estado de São Paulo), os quais serão substituídos no início da década de 1940 pelo SENAI (Serviço Nacional de Aprendizagem dos Industriários) sob o comando de seu primeiro diretor, Roberto Mange.

Deste modo, para a autora, as instituições de ensino (campo da particularidade de seu objeto, a socialização dos trabalhadores), desenvolvem atendimentos educacionais que, inicialmente, estiveram mais centrados na instrução primária e menos no ensino profissional. Posteriormente, o atendimento escolar desloca sua concepção pedagógica e objetivo formativo, bem como o público alvo. Abandona-se o projeto de estabelecimento de ensino do tipo quartel-convento-autossuficiente" (vertente correcional e moralista) para a forma fábrica-escola-fábrica" (vertente racional e produtivista).

\footnotetext{
${ }^{2}$ Victor Della-Vos (1829-1890), educador russo, elaborou um método de treinamento manual.
} 
A autora descreve e articula uma cronologia sequenciada dialeticamente, que permite perceber como os estágios técnico-produtivos e os projetos educacionais se articulam, se aproximam e se afastam em cada fase histórica. O fio condutor que confere historicidade aos projetos educacionais e políticos da burguesia paulista é a oferta escolar materializada nas instituições. Ganha destaque no grupo de estabelecimentos pesquisados, a Casa dos Educandos Artífices que, posteriormente, será transformada em Liceu de Artes e Ofícios de São Paulo e que, mais à frente, transformar-se-á em Escola de Mecânica. Sua infraestrutura, tipos de cursos, público alvo, metodologia de ensino e ideologia educacional vão se metamorfoseando no tempo. Como afirma a autora: "a ação do grande capital cafeeiro não se limitou às estradas de ferro ou às empresas de serviços urbanos, mas atingiu também o setor financeiro e, em menor grau, o comercial” (MORAES, 2003, p 192). Porém, após definida a face urbana do grande capital, há maior diferenciação dos seus interesses, o que traz reflexos para as estratégias econômicas e educacionais adotadas.

Moraes (2op. cit.) opera com a hipótese de que a difusão do ensino popular e do ensino profissional visa contribuir para a criação de condições mais estáveis para a acumulação do capital, através do controle institucional da formação e reprodução de uma força de trabalho sujeita às novas exigências do processo produtivo. Neste caso, "a Sociedade Propagadora da Instrução Popular e, mais tarde, o Liceu de Artes e Ofícios de São Paulo, "vai se constituir não só em espaço institucional de disciplinarização do trabalho, mas em mais um núcleo de organização e mobilização das frações dominantes " (Idem, p. 34).

\section{A Luta de Classes - Formação e Controle do Mercado de Força de Trabalho}

Para Moraes, em coerência com sua base epistemológica, a luta de classes constitui a totalidade mais ampla, que forma o conjunto de determinações sociais, econômicas e tecnológicas que estão na base dos projetos educacionais e as instituições de ensino em tela. Entre os muitos objetivos, nem sempre unânimes, que presidiram as ações e os discursos das elites paulistas envolvidas na gestão e na formulação dos projetos educacionais, destaca-se a intencionalidade de exercer a hegemonia do controle da formação do mercado livre da força de trabalho. Tal projeto hegemônico tenta responder às muitas contradições que envolvem três processos históricos complexos que vão da transição da Monarquia à República, da economia escravista ao trabalho livre e do predomínio da atividade agroexportadora ligada ao café à emergência da industrialização e urbanização.

Os limites das medidas eugênicas de reclusão da infância pobre e de importação da força de trabalho europeia, para fins de branqueamento da população, foram se tornando evidentes à medida que o desenvolvimento das 
forças produtivas e os conflitos de classe vão se impondo. Tal contexto implicará na transformação dos discursos e práticas das elites paulistas em relação aos seus projetos educacionais, demarcando as disputas na burguesia local que se moverá sem muitas rupturas internas. A tendência majoritária será de superar o discurso que tem o trabalho como fim moral, para afirmar o trabalho como fim produtivo.

Desta forma, o texto de Moraes evidencia a longa duração e as idas e vindas que percorrem a transição do trabalho escravo para o trabalho livre no Brasil. Segundo Moraes (idem), a "formação de um mercado de mão de obra consistiu num longo e difícil processo constituído por práticas diretamente repressivas e violentas, destinadas a impedir o acesso do trabalhador à propriedade da terra", aos meios de produção e, ao mesmo tempo, para viabilizar seu controle sobre o processo produtivo (ibid., p. 44). Na superação do modo escravista, o trabalho não foi apenas reproduzido e sim constituído como tal. Para Kowarick (1987) citado por Moraes, tais práticas foram acompanhadas de outras, de caráter cultural e educacional, de maneira que aqueles indivíduos, alienados dos meios materiais de vida "não só precisassem como também estivessem dispostos a trabalhar para os outros" (ibid., p. 44).

O processo histórico analisado demonstra momentos de crise que ensejam rupturas e descontinuidades, não apenas nas condições objetivas, mas também nas visões de mundo em disputa. A crise do modo escravista e do trabalho compulsório vai impactar as concepções de trabalho das classes dominantes, cuja estratégia de produção de excedentes terá que absorver, a partir de determinado momento, o trabalho livre e tudo que o envolve. Prisioneira de uma concepção arcaica de trabalho em que os trabalhadores "ex-escravos" só trabalhariam de modo forçado, as elites tiveram que superar essa visão pelo menos nos seus discursos para formar uma nova classe vocacionada para o trabalho livre.

Sobre isso, Moraes (2003), afirma que "as modificações nas relações de trabalho implicam em mudanças nas representações construídas pelos grupos dominantes sobre o próprio trabalho enquanto atividade produtiva, e sobre o novo elemento que surgia na vida social, o trabalhador livre" (Ibid., p. 161). Para tanto, segundo a autora, no discurso, era necessário "nobilitar o trabalho, livrá-lo do preconceito e do estigma da indignidade herdado da escravidão, reconvertendo-o no seu outro, no seu oposto, no culto ao trabalho na ilusão da liberdade" (ibid., p. 45).

A grande contradição que atravessa o discurso da elite sobre o trabalho é que, de modo maniqueísta, a partir de seus interesses, os mesmos grupos dominantes que distinguiam negativamente os escravos pelo trabalho, num determinado momento tiveram que conferir ao trabalho um novo significado de afirmação social. Nos seus projetos educacionais pretendiam difundir a ideia de que o trabalho seria o "portador da nova esperança de ascensão social, instrumento pelo qual todos se igualariam como cidadãos" (ibid., p. 45). 
Outra contradição ocorreu quando a estratégia de importação da força de trabalho branca, no contexto da emergência da luta sindical, pôs em xeque a tentativa de, simultaneamente, prover a mão de obra e branquear a sociedade. Mais uma vez, segundo Moraes (ibid.), a escola profissional foi tomada como solução para esta questão. Neste sentido, a instrução primária e o ensino industrial eram vistos como "veículo seguro para a nacionalização", e a necessidade de sua difusão como "questão patriótica":

[...] precisamos ter operários nossos, evitando-se a importação de elementos, muitas vezes banidos de suas terras de origem pelas ideias subversivas que professam, e que tudo anarquizam, pois, não lhes pesa na consciência, a desorganização social de uma terra extraordinariamente hospitaleira (SILVEIRA, 1920, apud MORAES p. 328).

Para Serva (1920), os governos e os patrões deveriam "criar e multiplicar em todos os meios fabris" instituições que dignificassem e elevassem o operário ao nível intelectual e moral das outras classes, integrando-o na atual ordem das coisas, tais como escolas, instituições de seguro, aulas técnicas de aperfeiçoamento, conferências, bibliotecas, salões, teatros, bilhares, salas e campos de todos os esportes. Na visão das elites, "desde que os homens são seres 'racionais', seria possível haver 'entendimento' entre eles pela harmonização de seus interesses", isto é, mediante a "harmonia de esforços de partilha do produto do trabalho coletivo da sociedade" (SERVA, apud MORAES, ibid., p. 226).

No período estudado por Moraes (ibid.), ocorrem as principais transformações da instrução primária e do ensino profissional no estado de São Paulo, economicamente o mais forte no país. São Paulo, por seu papel precursor nas estradas de ferro, na industrialização e no protagonismo empresarial na educação, será um dos espaços privilegiados para o estudo da gênese dos métodos, das práticas pedagógicas e das formas de organização que se darão ao ensino industrial no Brasil. As atividades desenvolvidas no estado se anteciparão ao SENAI, ao Sistema "S" e à Rede Federal de Educação Profissional e Tecnológica. Recuperamos, brevemente, os elementos chaves dos dois formatos de escola, os dois projetos educacionais desenvolvidos em tempos históricos distintos.

\subsection{Escola Quartel-Convento - Autossuficiente}

Para a autora (ibid.), os interesses imediatistas dos fazendeiros e a presença de uma indústria incipiente, "impeliam as 'elites' dirigentes", diante da crise do uso do trabalho escravo (e depois do trabalho infantil), a criar instituições com vistas a produzir uma eugenia como solução para o processo de urbanização para "conter os 'excessos' sociais da vadiagem, mendicância ou orfandade, fundando asilos, orfanatos e hospitais psiquiátricos ( p. 173). 
Do ponto de vista das elites, o dispositivo do Código de Menores ${ }^{3}$, ao proibir o trabalho de rua para menores com até 8 anos, não resolveu o problema de como fazer para encher o vazio do tempo ocioso das crianças abandonadas. Pesavam sobre elas "as circunstâncias físicas das intempéries, a incerteza da alimentação, a promiscuidade, causas da debilidade e moléstia" e ainda as "pavorosas condições morais da rua" (ALMEIDA JR. apud MORAES, 2003, p. 299). Mais ou menos autoritária, elitista ou preconceituosa é a visão da classe dominante. Dependendo das necessidades impostas socialmente, vão se estabelecer formas de incorporar estes setores marginalizados a instituições para seu aproveitamento como força de trabalho, farta e barata, em situações de escassez de mão-de-obra. Mas, em geral, "são sempre consensuais quanto à exigência de moralizá-los e cerceá-los do convívio social" (ibid., p. 299-301).

Nesses tipos de instituições voltadas para a socialização dos setores populares, o espaço concedido aos alunos, a organização do tempo de trabalho e de lazer são previamente planejados de maneira que todos os internos saibam que estão sob vigilância constante, de modo que possam "fazer uso ordenado e regrado do espaço e do tempo" (GRIGNON, 1971 apud MORAES, 2003 , p. 53). Até muitas instituições funcionavam como "mero depósito de crianças, que sujeitas à imposição da vontade institucional e submetidas a estrita vigilância, deveriam receber apenas o aprendizado da obediência" (ibid., 2003 p. 59).

A partir dos elementos historiográficos garimpados pela autora (ibid.), delineia-se uma primeira fase que vai de 1873 a 1894 na qual, dentre os muitos fatos elencados, ligados a instituições de ensino, destaca-se a criação da Casa dos Educandos Artífices em 1873 e sua posterior transformação no Liceu de Artes e Ofícios de São Paulo que, até 1894, abriga uma estrutura frágil de tipo muito próximo aos quartéis e aos conventos. Os alunos são compulsoriamente inseridos, vivem em semirreclusão, e são obrigados a gerar, pelo seu trabalho e pela sua produção, a manutenção do estabelecimento autossuficiente, o que caracteriza sua pedagogia assistencial e moralista.

No final do século XIX as escolas, como as sociedades protetoras, dependiam de "donativos" das companhias de estradas de ferro e da renda das oficinas (ibid., p. 81). Anualmente, cursos práticos como os da alfaiataria tinham sua produção exposta ao público e vendidas e "o dinheiro arrecadado era dirigido para reposição dos gastos ou revertido para os alunos como pecúlio aos órfãos, quando completavam o período de internação" ( $A$ Provincia de São Paulo apud MORAES, ibid., p. 79).

A combinação de vários fatores relacionados à sobrevivência material dos estabelecimentos influenciava o seu funcionamento. A manutenção dos estabelecimentos, a gestão empresarial-filantrópica, a subvenção oficial deficitária, fazia com que tais espaços fossem mantidos pelos próprios alunos, cujo

\footnotetext{
${ }^{3}$ Em 1891 foi estabelecida a idade mínima para o trabalho no Brasil, com a promulgação do Decreto ${ }^{\circ} 1.313$ que determinava a idade mínima de 12 anos para o trabalho.
} 
trabalho compulsoriamente imposto gerava obediência, ocupação e produção que os tornava precariamente autossuficientes atendendo a objetivos educacionais muito restritos em relação à formação profissional.

\subsection{Escola -Fábrica-Escola}

Os estudos historiográficos que desenvolvemos nos permitem apreender uma periodização que indica os estágios de desenvolvimento histórico da instrução primária e do ensino profissional, que se situa no espaçotempo de São Paulo na virada do século XIX para o XX, e que vai até o primeiro governo Vargas. Este período demarca uma nova fase do projeto educacional das elites paulistas, através das experiências inovadoras do Liceu de Artes e Ofícios de São Paulo, instituição essa que se constituiu como vanguarda pedagógica ao superar as práticas pedagógicas anteriores iniciadas por Ramos de Azevedo. Mas, sobretudo, a transformação se fará a partir de Roberto Mange, que dará vida a uma concepção e pratica pedagógica vinculadas ao formato racional e psicotécnico, os estabelecimentos do tipo Escola-FábricaEscola).

Durante os diferentes governos do primeiro período republicano, a atuação do Estado e da iniciativa privada convergiam para os mesmos objetivos, construir e expandir uma rede de ensino. Embora não descuidassem das providências voltadas para a criação de escolas secundárias e superiores, em número e qualidades desejadas, incidiram com particular ênfase sobre a organização do ensino primário e a formação de seus professores. O controle disciplinar da população pobre que se aglomerava nas cidades, acrescida dia a dia pela chegada de imigrantes e, a partir de meados de 1910, dos imigrantes rurais que passavam a ser incorporados ao mercado de trabalho urbano, incluía uma ênfase particular na "educação sanitária" (MORAES, 2003, p. 344).

O Liceu de Artes e Ofícios, em sua terceira fase, passou por uma reestruturação física e pedagógica na gestão de Ramos de Azevedo. "Em 1895 é amplamente reformulado e instalado em prédio novo com execução completa de seu programa como escola profissional de artes e ofícios" (ibid., p. 175). Essa remodelação implanta um amplo programa voltado para a formação de quadros intermediários para indústria da construção civil (ibid., p. 177).

Mantido como instituição não pública, mas ainda precariamente subsidiada pelo poder público, constituiu-se como estabelecimento privado de ensino, motivo de orgulho do setor empresarial. Em 1915, por ocasião da exposição do mobiliário produzido nas oficinas, o Jornal "Estado de São Paulo" elogia a escola caracterizando-a como exemplo de "criação da beneficência particular" "de administração extraoficial" Atribui o sucesso de sua "eficiente e produtiva ação como instituto profissional" ao fato de sua direção não pertencer "ao organismo burocrático do Estado" (O Estado de São Paulo de 24/01/1915 apud MORAES, ibid., p. 178). 
O Liceu, conhecido posteriormente pelos seus vínculos com as empresas ferroviárias e pelo trabalho no campo da mecânica, ganhou importância na formação de quadros para os setores produtivos emergentes, em complemento aos cursos de Engenharia Civil e de Arquitetura da Escola Politécnica. A ligação entre os dois estabelecimentos ocorre, em primeiro lugar, em nível do corpo docente. Segundo Moraes (ibid.), além de Ramos de Azevedo, faziam parte da sociedade e da diretoria do Liceu: Luiz Anhaia de Melo, João Pereira Ferraz, Victor da Silva Freire, Francisco Ferreira Ramos, Urbano Vasconcelos, Geraldo de Paula Souza, Augusto Ramos e outros (Ibid., p. 180). De 1890 a 1934, um número bastante expressivo de membros do Liceu exercerá funções políticas partidárias ocupando, por vezes cargos, na administração pública (ibid., p.186).

A ligação do Liceu com o setor produtivo e com o Estado manterá a instituição num dilema de servir ao meio empresarial, mas também de depender do subsídio público, contexto que explica a questão pedagógica que atravessará, definindo e redefinindo sua identidade, inicialmente como fábricaescola e posteriormente como escola-fábrica. O produto do trabalho das oficinas do Liceu vai se tornando responsável por parcela cada vez maior da manutenção da escola, reafirmando não só os objetivos de autossuficiência da instituição, como também seus propósitos de lucratividade. Siqueira Campos, em 1920, afirma que "a deficiência do nosso meio em operários competentes neste gênero de trabalho, justifica plenamente a montagem de uma oficinaescola" (SIQUEIRA CAMPOS apud MORAES, ibid., p. 362).

A proposta educativa do Liceu baseava-se na criação de "oficinas escolas" em oposição às "escolas oficinas". A ênfase nas "oficinas escolas" significava priorizar a transmissão do conhecimento durante a prática profissional, de maneira a instruir fazendo. O aluno, admitido como simples aprendiz, se instruía, observando o trabalho dos mestres ou realizando parte dele (MORAES, 2003, p. 362). Segundo Severo, "a grande indústria escola seria sempre mais lucrativa (a exemplo do Liceu) do que estabelecer a pequena escola profissional, sempre dispendiosa, incompleta, e, por vezes, de discutível utilidade prática" (apud MORAES, ibid., p. 364).

Para superar essa prática, Roberto Mange vai propor uma maior distinção entre os espaços formativos e os espaços produtivos. Para Mange, a oficina-escola ensejava distorções, fazendo com que aprendizes ficassem submetidos a uma repetição excessiva dos movimentos que precisam ser realizados apenas para o domínio da habilidade e não para a produção. Nesse sentido, a gestão de Mange demarcará uma formação baseada na "fábrica-escola". Para Mange a "industrialização" das oficinas da escola, cujo objetivo era "explorar o trabalho dos alunos com fins comerciais" poderia desvirtuar os fins pedagógicos como é o caso do modelo do self-supporting (SEVERO apud MORAES, ibid., p. 381). 
Já na década de 1920, Roberto Mange e Paulo Pestana, defensores iniciais da função industrial das escolas, como forma de gerar fonte de recursos e melhor aproximar o ensino das necessidades da produção, fazem restrições à sua industrialização completa. Segundo Mange, introduzir no ambiente de estudos "a luta pela vida, viria a prejudicar o desenvolvimento de aptidões e capacidades. Tal ação faria manietar o princípio da sucessão metódica dos trabalhos". Deste modo, a escola, mesmo dispondo de recursos gerados pela sua própria produção, não poderia dispensar o auxílio pecuniário do Estado (MORAES, ibid., p. 381).

Mas, na fase fábrica-escola, o Liceu, foi adquirindo mais contornos de uma empresa e colocando os objetivos educacionais em plano secundário. Os objetivos da instituição inicialmente escolares, "passaram a ser, depois, exclusivamente de interesse fabril mantendo apenas o ensino primário noturno para os aprendizes". Segundo Luderitz (1925),

[...] existe ali o regime de aprendizagem espontânea; o aluno entra pequeno, analfabeto quase sempre, vai para uma oficina percorrendo em vários anos, as diversas especializações de um grupo de ofícios correlatos e feita, após cinco ou seis anos, sua prática na profissão, aprendeu a ler e escrever e desenhar, um pouco; sai um homem feito, ótimo operário. (LUDERITZ, 1925, apud MORAES p. 385).

Diante da amplitude assumida pela questão operária, a Escola de Mecânica do Liceu de Artes e Ofícios atualiza o projeto educacional das elites progressistas (industrialistas, racionalistas e positivistas) ao relacionar "a organização científica do trabalho", o "ensino profissional" e o "recrutamento de oficiais", superando os métodos rotineiros que "lançam jovens nos formigueiros da oficina industrial, deixando-os aprender como puderem" ( $O$ Estado de São Paulo, 28/09/1929 apud Moraes,2003, p. 244). Por intermédio da "psicotécnica", da "pesquisa de aptidões" é possível obter-se "economia de tempo na aprendizagem", redução do número de acidentes e economia de energia e de material (ibid., p. 245).

$\mathrm{Na}$ virada do século, mas, sobretudo a partir dos anos 1920, o processo de constituição de um mercado da força livre de trabalho foi acompanhado pela formulação de estratégias pontuais para disciplinarização e sujeição dos trabalhadores. Essas estratégias vão tomar a organização fabril como paradigma para reordenação da sociedade (ibid., p. 233). Nesse movimento, o projeto educacional renova-se para atender às novas necessidades geradas pela modernização das relações capitalistas, às necessidades colocadas pela racionalidade industrial. Ou seja, a instituição escolar, através de seus diferentes níveis e graus passa a ser utilizada como mecanismo de legitimação e reprodução das relações sociais de exploração e opressão inerentes a esse tipo de sociedade, favorecendo a produção de representações e práticas conformadoras e reafirmadoras do poder dominante (ibid., p. 247). 
A difusão dos princípios do taylorismo tinha por finalidade interferir tanto no processo de socialização da força de trabalho assalariada, como na formação ideológica da tecnocracia industrial (ANTONACCI, apud MORAES, 2003, p. 248). Medidas racionalizadoras permeiam a proposta educacional desde a organização e funcionamento dos sistemas escolares e seus objetivos sociais de hierarquização e disciplinarização social, até a adoção de "métodos modernos" (MORAES, ibid., p. 248).

\section{Considerações Finais}

O trabalho de Moraes possibilita acompanharmos a relação entre Estado e os trabalhadores, sob o prisma da instrução popular como estratégia pedagógica fundamental das elites dominantes. A autora destaca a influência das organizações privadas patronais junto às instituições de instrução popular, na conformação da luta de classes em favor da classe dominante, através da construção da estrutura organizacional e pedagógica da escolarização no Brasil com o apoio do Estado. A escola segue bem representada como instrumento patronal no período destacado, definida pelas necessidades do capital.

A autora retrata a história política de pactuação de classes e arrefecimento das lutas dos trabalhadores promovida pelas elites, como herança da aliança entre as classes dominantes rurais e urbanas no Brasil, e do fim do tráfico de escravos fomentado por interesses econômicos e pela pressão internacional. Fortalecendo a hegemonia da burguesia industrial, especialmente pós-crise de 1929, o Brasil consolidou as indústrias de bens de consumo não duráveis, sob a égide do modelo de substituição de importações.

O texto de Moraes traz a passagem do núcleo de instrução da Fábrica-Escola para a Escola-Fábrica. No regulamento das escolas profissionais oficiais, no primeiro formato, constava a proibição dos alunos participarem dos movimentos grevistas, sob pena de expulsão da escola, demonstrando total subordinação dos interesses pedagógicos aos fabris. Após a escolarização, no trabalho, o controle e a avaliação moralista permaneciam presentes, trazendo fortes conteúdos racistas como herança do passado escravista. No segundo formato, o controle do Estado veio complementar as ações da iniciativa privada. Seguindo a proposta de Victor Della Vos, as escolas que traziam a mesma concepção anterior, apresentavam-se mais completas, visando a formação e não a produção, para no final produzir o trabalhador. Esse modelo constituiu a base pedagógica do CEFESP que deu origem ao SENAI.

Neste trabalho podemos perceber como importantes elementos historiográficos nos ajudam a compreender o tema em análise, no qual a mediação espaço-tempo atravessa de modo não linear, mas eivado de inúmeras contradições na disputa pelo controle do mercado de trabalho livre na sociedade paulista no início da República. Destaca-se a força explicativa da obra no contexto 
das tensões e soluções buscadas para as crises econômicas num campo de luta de classes com implicações decisivas para a educação dos trabalhadores. 



\section{$\mathrm{X}$ \\ RELAÇÕES E TENSÕES ENTRE TRABALHO, ESCOLA E PROFISSIONALIZAÇÃO - O livro de Silvia Maria Manfredi ${ }^{*}$}

Sandra Morais

Rosângela Rosa

\section{Introdução}

A proposta desta pesquisa é compreender de que forma Silvia Maria Manfredi (2002) escreve a história da educação profissional. Percebemos que para resgatar a história da Educação Profissional no Brasil, Manfredi vai além das dimensões escolares. Ela vai pesquisar o que se tem produzido historicamente em outros espaços sociais: sindicatos, empresas, associações de bairro, associações comunitárias, movimentos sociais. A autora investiga além da perspectiva oficial e da orientação hegemônica. Seu livro escrito no ano de 2002 faz parte da Coleção Docência em Formação, voltada prioritariamente para frequentadores de cursos de formação de educadores e, também, para especialistas em Educação Profissional. Assim, foi estruturado para servir de subsídio à formação inicial e continuada de profissionais que vão atuar (ou já atuam) em atividades de Educação Profissional, em diferentes níveis e espaços formativos.

O livro está dividido em duas partes: na $1^{\mathrm{a}}$. Parte, intitulada "A Educação Profissional ontem e hoje", que a autora considera central, são analisadas as relações entre educação, trabalho e sociedade, dando destaque à educação escolar, mas com a ressalva que ela não esgota a formação para o trabalho. Nesta primeira parte, a autora também discorre sobre a educação profissional no Brasil desde o período colonial até a República em 1990. Na 2a. Parte, intitulada "Diferentes protagonistas: concepções, práticas e políticas educativas", Manfredi vai recuperar os projetos políticos e sociais em três âmbitos: Estado, sociedade civil, movimento sindical e movimentos sociais.

Sua observação sobre a historicidade dos períodos está alicerçada em diversos autores que abordam a educação, a história, a história do ensino profissional, aspectos culturais, sociológicos, políticos, filosóficos, econômicos e outras questões de fundo pertinentes à sua produção.

\footnotetext{
*DOI - 10.29388/978-85-53111-86-2-f.181-198

${ }^{1}$ MANFREDI, Silvia Maria. Educação profissional no Brasil. São Paulo: Cortez, 2002. Este texto foi desenvolvido como parte do Projeto de Pesquisa CIAVATTA (2012).
} 
O tempo histórico, incorporado pelos grupos dos Annales $^{2}$ quando identifica a longa duração às estruturas, a média duração às conjunturas e a pequena duração aos acontecimentos, está presente no desenvolvimento de sua proposta analítica.

Para construir a história da educação no e para o trabalho, no Brasil, Manfredi se depara com duas dificuldades: "a tradição historiográfica de pesquisa que privilegiou a educação propiciada nos espaços escolares, e, como afirma Cunha (2000), os estudos acerca da educação escolar, que têm privilegiado pesquisas sobre o ensino superior e sobre o ensino médio, em detrimento do ensino profissional" (p. 65). Para Cunha isso se explica, "pelo fato dos historiadores da educação brasileira se preocuparem, principalmente com o ensino das elites e do trabalho intelectual" (MANFREDI, op. cit., p. 65, apud CUNHA, 2000d, p. 89, grifos da autora). Logo, são recentes as investigações das práticas de educação que ocorrem em outros espaços sociais.

O trabalho ousado de Manfredi ainda incorpora, ao final, como anexo, comentários críticos sobre o Plano Nacional de Educação de 2001.

\section{A autora e sua obra}

Silvia Maria Manfredi nasceu na província de Cueno, na Itália, em março de 1946. É professora aposentada da UNICAMP e atualmente é presidente do Instituto Paulo Freire na Itália, onde reside. A sua trajetória de pesquisa e o livro que estamos analisando estão vinculados à sua vida pessoal e profissional. Atuou como pedagoga dos movimentos de educação popular no Brasil nos anos 60 e 70. Participou também dos movimentos populares na cidade de São Paulo contra a ditadura civil-militar. Pesquisou do DIEESE (Departamento Intersindical de Estatística e Estudos Socioeconômicos), atuando também na formação sindical dos trabalhadores.

Nos anos 1990 participou da Formação Sindical da CUT (Central Única dos Trabalhadores de São Paulo e em nível nacional). Entre seus principais desafios diante dessa trajetória estava a questão: por que dentro das pesquisas acadêmicas não era dada voz aos trabalhadores no campo da educação em geral?

No livro da tese do doutorado, desenvolveu a análise das práticas educativas no movimento sindical no Estado de São Paulo. Ampliando suas análises para o Brasil, resgatou as suas principais experiências de educação sindical, tendo como fontes entidades sindicais de âmbito nacional, como a FASE (Federação de Órgãos para Assistência Social e Educacional), o DIEE-

\footnotetext{
2 A Escola dos Annales, liderada primeiramente por Marc Bloch e Lucien Febvre, foi um movimento historiográfico surgido na França, durante a primeira metade do século XX (BURKE, 1992).
} 
$\mathrm{SE}^{3}$ e algumas das centrais sindicais já organizadas.

A autora destaca que nessa pesquisa fez o esforço de recuperar historicamente as práticas educativas, desde os anarquistas, observando, quais foram as práticas de educação sindical mais realizadas ao longo da história do movimento, até os anos 1980. Ressalta, ainda ter recuperado algumas das práticas dos partidos políticos de esquerda, concluindo que a formação sindical, nos anos 1940 e 1950, constituía-se nas ações assumidas, na maior parte, pelos partidos políticos, e menos pelas entidades sindicais. Teve uma participação ativa nos partidos políticos e movimentos que atuaram no processo de resistência e luta contra a Ditadura Militar, sendo uma das protagonistas de um movimento de transformação social, nos anos 1968-1969, junto aos setores da sociedade civil brasileira que lutaram pela redemocratização. Participou das campanhas de alfabetização, no período de 1965 a 1969, durante o primeiro período da Ditadura Militar.

As bases teóricas do livro que estamos analisando são, segundo a autora histórico-sociológicas. Cita três vertentes principais: os clássicos marxistas, como Gramsci; os historiadores marxistas como Edward P. Thompson, Eric Hobsbawn e Peter Burker; a corrente francesa da Nova História e os autores brasileiros como Luiz Antônio Cunha, Gaudêncio Frigotto, Acácia Kuenzer, entre outros.

Manfredi trabalha com diferentes sujeitos e atores sociais que atuam no campo da educação profissional vinculados ao Estado e ao campo social da educação. Vê o campo da educação profissional como um espaço de disputas de projetos, de políticas educacionais e de políticas sociais. Logo, é um espaço de luta entre o Estado, através do MEC (Ministério da Educação e Cultura e do MT (Ministério do Trabalho), os empresários e os trabalhadores.

No entanto, destaca que existem outras entidades da sociedade civil que também participam dessa disputa, como por exemplo, o MST (Movimento dos Trabalhadores sem Terra). Ela pesquisa como se deu essa disputa durante os governos de Fernando Henrique Cardoso (1995-1998-2002) e do governo Lula (2003-2007-2010).

No ano de 2016, Manfredi lançou um novo livro denominado "Educação Profissional no Brasil - Atores e Cenários ao longo da História”. Nele faz não só uma revisão de alguns capítulos do livro que estamos analisando, atualizando-o, mas incluindo também uma terceira parte onde analisa os governos Lula de 2003 à 2010, e o primeiro ano do governo Dilma (2011). Ressalta, principalmente, que a história e as lutas dos trabalhadores nesse período não podem jamais ser esquecidas.

As experiências e a militância de Manfredi nos ajudam a compreender a sua opção em realizar um trabalho emancipatório de educação das classes subalternas. Sua trajetória profissional foi centrada na experiência do Sindicato

${ }^{3}$ O DIEESE nasceu da luta dos dirigentes sindicais brasileiros e foi fundado em 1955, com o objetivo de desenvolver pesquisas que subsidiassem as demandas dos trabalhadores. 
dos Metalúrgicos de São Paulo, onde realizou um trabalho de educação, e pesquisas em educação popular no Grupo de Educação Popular na Pontifícia Universidade Católica - PUC São Paulo, onde desenvolveu uma série de materiais didáticos produzidos para o movimento popular, o movimento sindical, baseado na metodologia da história de vida. Tais trabalhos foram nomeados como "Cadernos dos Trabalhadores". Manfredi se ocupa, principalmente, dos seguintes temas: educação sindical, história, movimento sindical. Suas pesquisas ${ }^{4}$ são desenvolvidas nas áreas: educação e trabalho, educação e movimentos sociais, história oral e educação sindical e profissional.

\section{As fontes de pesquisa}

O uso das fontes varia no tempo e no espaço, de acordo com o interesse do pesquisador, as fontes documentais são a matéria-prima dos historiadores, e, se constituem como um elemento de suma importância na produção historiográfica.

[...] nem sempre os monumentos ou os documentos afloram de forma que se tornem conhecidos e utilizáveis pelo homem para entender como viveram e vivem os próprios homens. Assim, não resta alternativa ao historiador: é preciso definir claramente o que deseja estudar, recortando e delimitando o objeto de investigação; feita a(s) escolha(s), é necessário buscar outro tipo de fonte que ajude a reconstruir (em pensamento) o objeto de investigação delimitado. (LOMBARDI, 2004, p. 156).

No trabalho de pesquisa de Silvia Maria Manfredi, identificamos pela descrição das fontes, uma quantidade significativa de documentos ${ }^{5}$. Como ressalta Pinsky (2008, p.7), as fontes têm historicidade e, na busca desta historicidade, a autora elegeu documentos primários, fontes de época. Saviani permite ampliar a compreensão sobre o tema:

\footnotetext{
${ }^{4}$ A autora publicou e organizou vários livros, tem artigos e capítulos de livros publicados no Brasil, sobre educação profissional, formação de profissionais de educação, formação e educação popular, formação sindical e outros temas afins.

${ }^{5} \mathrm{O}$ trabalho apresenta como fontes primárias documentos da CUT (Central Única dos Trabalhadores), CGT (Comando Geral dos Trabalhadores), CNI (Confederação Nacional da Indústria), SESI (Serviços Social da Indústria),, SENAI (Serviço Nacional de Aprendizagem Industrial), IEL (Instituto Euvaldo Lodi), CNM (Confederação Nacional dos Metalúrgicos), CONCUT (Congresso Nacional da CUT), DIEESE (Departamento Intersindical de Estudos Estatísticos e Socioeconômicos), Força Sindical, MST, (Movimento dos Trabalhadores Rurais Sem Terra), MTb, (Ministério do Trabalho), Sefor (Secretaria de Formação), Planfor (Plano Nacional de Qualificação do Trabalhador), SM-SP (Sindicato dos Metalúrgicos de São Paulo), SNF/FS, (Sindicato Nacional da Força Sindical) STI. (Sindicato de Trabalhadores de Impostos).
} 
[...] Assim as fontes históricas não são a fonte da história, ou seja, não é delas que brota e flui a história. Elas, enquanto registros, enquanto testemunhos dos atos históricos são as fontes do nosso conhecimento histórico, isto é, é delas que brota, é nelas que se apoia o conhecimento que produzimos a respeito da história. (SAVIANI, 2006, p. 29-30).

Segundo Andreotti $(2005$, p. 3) tudo que compõe um acervo de documentos, constitui-se em fontes de pesquisa. Elas emergem do movimento de investigação do pesquisador, são fontes produzidas no contexto temporal na qual se inserem. São classificadas como fontes primárias quando são produzidas por quem teve contato com os fatos relatados.

O trabalho de análise documental de Manfredi consistiu, também, em uma significativa busca de referências em outros autores que escrevem sobre educação profissional no Brasil, as fontes secundárias. A autora utilizou documentos que permitem uma compreensão crítica dos processos de reordenação institucional em curso na sociedade brasileira.

\section{O Tempo Histórico - A longa duração das estruturas, a média duração das conjunturas e a breve duração dos acontecimentos}

A obra de Manfredi corresponde a um período histórico longo. Sua análise aborda desde o período da educação jesuítica, para formação catequética dos índios brasileiros, até a história contemporânea, portanto, atravessa séculos. Mas sua pesquisa focaliza as diversas conjunturas da vida nacional e os principais acontecimentos que marcam a concepção e a organização da educação profissional no Brasil.

O passado só se torna história quando expressamente interpretado como tal; abstraindo-se dessa interpretação ele não passa de material bruto, um fragmento de fatos mortos, que só nasce como história mediante o trabalho interpretativo dos que se debruçam, reflexivamente, sobre ele. (RÜSEN, 2001, p. 77).

Elegemos como referência, para análise da questão tempo, Ferdinand Braudel, considerando a pesquisa do livro, Mediações históricas de trabatho e educação (CIAVATTA, 2009). Nessa matéria, a grande contribuição de Braudel é a dos tempos múltiplos, as diversas dimensões que podem e devem ser levadas em conta na pesquisa:

A duração social, esses tempos múltiplos e contraditórios da vida dos homens que são não só substância do passado, mas também a matéria da vida social atual [...] para nós, nada há mais importante, no centro da realidade social, que esta viva e última posição, infinitivamente repetida, entre o instante e o tempo lento no decorrer. Quer se trate do 
passado, quer se trate da atualidade, torna-se indispensável uma consciência nítida dessa pluralidade do tempo social para uma metodologia comum das ciências do homem. (BRAUDEL, apud CIAVATTA, 2009, p. 88-89).

Braudel (1987) considera três tipos de tempo: a reconstrução, ou seja, a organização do material do conhecimento, a concepção do autor e o tempo vivido da realidade. Inclui, em sua dialética da duração, o tempo real e o tempo reconstruído; o tempo reconstruído é a visão geral da história do historiador. Braudel visualiza estrutura, conjuntura e evento como camadas cuja espessura vai se modificando com o correr da história.

A pesquisa de Braudel (id.) concebe os tempos heterogêneos (temporalidades diferentes), classificados como: os tempos de longa duração, o tempo médio das conjunturas e o tempo breve dos acontecimentos. Esses três tempos fazem referência a três ordens de durações históricas das realidades analisadas pelas ciências sociais e pela história.

O historiador e filósofo alemão Rüsen (2009), desenvolveu estudos que também nos interessam por abordarem a teoria da história e sua relação com o trabalho desempenhado pelo historiador. O pensamento histórico torna-se especificamente científico quando segue os princípios da metodização, quando submete a regras todas as operações da consciência histórica, cujas pretensões de validade se baseiam nos argumentos das narrativas, nas quais esses fundamentos são aplicados sistematicamente.

Serão estas as concepções de tempo e do trabalho histórico que permearão nossas análises. Pretendemos, portanto observar de que forma a autora realizou seu trabalho historiográfico, tendo por base, tais conceitos.

\section{Categorias de análise e historiografia}

Na pesquisa que subsidia este artigo sobre o livro de Manfredi, alguns conceitos são imprescindíveis para construção de categorias analíticas na historiografia, como caminho para a compreensão da totalidade social. Trabalharemos com conceitos mais gerais na perspectiva de esclarecer aspectos na realidade social da educação e do trabalho, e as relações estabelecidas no tempoespaço em que os fenômenos ocorrem, considerando serem a história e sociedade duas realidades inseparáveis.

Vilar (1985), no estudo Iniciação ao vocabulário da análise histórica, nos lembra que "o objeto da ciência histórica é a dinâmica das sociedades humanas" (p. 42). Assim, para dominar a matéria histórica é necessário estudar os tipos de fatos que a constituem no tempo-espaço e na totalidade social a que pertencem. A historiografia precisa da historicidade como categoria fundamental para sua constituição. Interessa-nos, por isso, observar de que forma Manfredi constrói sua análise histórica partindo desses referenciais. 
Outra questão a ser considerada refere-se às categorias de análise. Ao aprofundarmos as análises, percebemos que o estudo baseado em categorias nos permite tomar os objetos e ordená-los de modo diferenciado. Quanto às categorias e conceitos, Ciavatta (2012) esclarece:

\begin{abstract}
Na língua portuguesa, categoria e conceito são termos utilizados quase indistintamente nos trabalhos científicos, podem até ter o mesmo significado enquanto termos que se referem a algum atributo dos seres. Mas também podem servir a uma ordenação mais precisa desses atributos. [...] Categorias e conceitos são termos que lidam com o visível e o invisível. Tanto os objetos e fenômenos visíveis quanto os invisíveis ou de pensamento, são seres materiais ou mentais (afetivos, emocionais, intelectuais etc.) em situação de relação com outros tantos seres e servem para ordenar a realidade ao nível do pensamento e do discurso oral, escrito etc. Por isso, sua denominação geral ou específica é relativa ao universo a que se referem (p. 69).
\end{abstract}

Para ampliar a nossa compreensão sobre o uso das categorias na pesquisa, recorremos a Marx (1982), considerando a importância das categorias para apreender a síntese social e recuperar as relações sociais com caráter histórico e transitório do modo de produção, em uma época determinada. Assim, nossa "lente" para olhar o trabalho de Manfredi se constituirá com as categorias apresentadas a seguir.

\title{
4.1. Trabalho e profissão
}

Manfredi (2002) destaca que as relações entre trabalho, emprego, escola e profissão são muito mais complexas do que imaginamos. Ressalta também que no senso comum, o termo trabalho vem logo associado à ideia de emprego, e que as relações entre trabalho e escola são cercadas de "visões ambíguas e idealizadas" (p. 31).

São ambíguas na medida em que negam a importância da escola e supervalorizam a experiência do trabalho, acreditando que o trabalho é a verdadeira escola. De outro lado, há visões que superestimam a importância da escola, acreditando que ela forma o profissional que vai ingressar no mundo do trabalho. Para a autora são visões "estereotipadas e reducionistas de relações e de processos históricos complexos" (id., p. 32).

Segundo a autora, são as diferentes esferas da sociedade, compreendidas entre as relações econômicas, sociais, políticas e culturais que determinam a complexa relação entre trabalho, escolaridade e profissão. Essas, por sua vez, são marcadas por uma rede de determinações, mediações e tensões. Logo, o sistema de educação escolar, assim como as instituições sociais (igreja, família, Estado, empresas, sindicatos etc.) são, historicamente, "datado(s) e situado(s)". A autora vai trabalhar com algumas categorias para apresentar as "múl- 
tiplas e complexas relações entre trabalho, emprego, profissionalização e escolarização" (id., p. 32).

Sabemos que o trabalho é uma atividade social essencial para as civilizações. Segundo Dereymes (1995), o trabalho é a base para estruturação das categorias sócio-profissionais, constituindo-se não só em identidades socioculturais, como, também, está sujeito a competições e conflitos. E constitui-se em objeto de ação e intervenção de políticas governamentais.

Portanto, é unânime entre os estudiosos e teóricos sobre o assunto, que a determinação da noção de trabalho e as suas formas concretas de efetivação são históricas. Elas vão "variando de acordo com os modos de organização da produção e de distribuição de riqueza e poder" (MANFREDI, id., p. 34 ), como, por exemplo, nas sociedades primitivas, nas sociedades agrícolas e no seu desenvolvimento.

Importante ressaltarmos, conforme Manfredi, que a divisão social do trabalho está ligada diretamente às funções sociais presentes na produção, na distribuição e no comércio de bens, além de serem fundamentais as funções ligadas à política e à religião. Os trabalhadores pré-industriais controlavam todo, ou grande parte, do seu processo de trabalho. No entanto, na passagem da produção de subsistência para a produção visando o mercado, ocorreu uma metamorfose fundamental. Surgiu o capitalismo como um novo modo de produção, na Europa, entre os séculos XV e XVI. Porém, nos países mais pobres que foram colonizados pelos europeus, como é o caso do Brasil, essas transformações ocorrerão muito tempo depois, com o esgotamento da Colônia, o fim da escravidão, o crescimento do trabalho assalariado e sua expansão no século $\mathrm{XX}^{7}$.

Ao se referir à origem das Corporações de Ofícios, Manfredi destaca que elas estão presentes a partir da divisão social do trabalho, responsável por constituir grupos homogêneos de pessoas e instituições "posteriormente substituídas pelos grupos ocupacionais ou profissionais" (id., p. 39). Logo, as profissões nascem não só pela complexidade e pelas modificações nas funções de comando, controle e defesa social, como também pelas necessidades inerentes às transformações dos processos produtivos. Manfredi cita dois importantes autores, Thompson (1989) e Hobsbawn (1987), que pesquisam a fundo as transformações que aconteceram nos diversos ofícios.

\footnotetext{
${ }^{6}$ As palavras profissão e profissionalização, tem a mesma raiz latina, professione, ato ou efeito de professar, "uma crença, sentimento, opinião ou modo de ser". A autora utiliza os dois termos, ao que parece, indistintamente. Entendemos que, neste contexto, a palavra profissão tem o sentido de "atividade ou ocupação especializada, e que supõe determinado preparo"; a profissionalização é "o ato de tornar-se profissional" de adquirir o preparo.

${ }^{7}$ Para análise detalhada, ver Prado Júnior (2000) e Mello (1986). Sob o tema "o capitalismo tardio", Melo discute a análise da CEPAL (Comissão Econômica para a América Latina) com foco no "problema da especificidade do capitalismo periférico, mais precisamente, com as peculiaridades da industrialização capitalista, no contexto latino-americano" (BELLUZZO, 1986)
} 
As transformações ocorridas na passagem do trabalho artesanal para o fabril e posteriormente industrial, ocorridos entre os séculos XVIII e XIX, é que produzem o trabalhador livre, de atividade assalariada. Enguita (1989) vai ressaltar as seguintes características presentes no trabalho assalariado sob a égide do capitalismo. A primeira delas é a separação entre trabalho manual e intelectual. Logo, a seguir, destaca que: "o controle hierárquico e a disciplina são essenciais para que o capital possa alocar tarefas, impor velocidades e intensificações, punir a má qualidade" (p.10, apud MANFREDI, 2002, p., 43). A terceira característica fundamental, diz respeito à fragmentação / desqualificação que, segundo o autor, são inerentes ao processo de trabalho no modo de produção capitalista.

Manfredi ressalta, entretanto, que, apesar de o trabalho assalariado ser uma modalidade recorrente nas sociedades capitalistas contemporâneas, ainda persistem outras formas, "como o doméstico e o trabalho por conta própria (ou autônomo)" (id., p. 44). Nas sociedades industriais modernas, as ocupações e funções relacionam-se aos diferentes setores e ramos da economia: indústria, comércio, agricultura e serviços. Por outro lado, o grupo dos trabalhadores assalariados é heterogêneo e amplo e exerce diferentes funções, com níveis de escolaridade diferenciados e com diferentes graus de subordinação ao capital

No Brasil, a partir da década de 1990, quando a indústria deixa de ser direcionada não só para o mercado interno, mas para o competitivo mercado internacional, "o país passou a conviver, pela primeira vez desde os anos 1930, com a perda absoluta e relativa de postos de trabalho na indústria manufatureira" (id., p. 48). Assim, Manfredi reafirma, que, conceitualmente, há uma diferença entre trabalho e emprego. Que tanto os tipos de trabalho, como as condições de emprego, dependem muito mais de questões estruturais do que de processos educativos. Só a educação, enquanto processo social, não gera trabalho nem emprego.

A criação de novas ocupações e de novos postos de trabalho está relacionada ao crescimento econômico, às políticas de distribuição de renda, à criação de novos empregos, entre outros aspectos. Logo, "nessa linha de argumentação, a educação profissional, enquanto prática social é uma realidade condicionada, determinada e não condicionante de qualificação social para o trabalho e para o emprego" (id., p. 50). Por outro lado, o desenvolvimento tecnológico, advindo da ciência moderna, está gerando mudanças quantitativas e qualitativas na estrutura ocupacional e nos postos de trabalho.

\subsection{Educação e Educação Profissional}

Analisando a nova institucionalidade do projetos educacionais, no âmbito do Estado, a partir dos anos 1990, Manfredi destaca que após a implantação da Lei de Diretrizes e Bases da Educação, Lei 9.394/96 e do Decre- 
to Federal 2.208/97, instituíram-se as bases para a reforma do ensino profissionalizante no Brasil. Durante este processo, diferentes projetos são defendidos por diversos protagonistas sociais como por exemplo, os trabalhadores, os empresários e o governo.

No âmbito do governo de Fernando Henrique Cardoso, nas duas gestões (1995-1998-2002), encontram-se dois projetos distintos: um do Ministério do Trabalho e outro do Ministério da Educação. No âmbito da sociedade civil, várias entidades de educação e pesquisa, do movimento social e sindical, organizaram-se no Fórum em Defesa da Escola Pública.

O projeto defendido pelo Ministério do Trabalho, por meio da Secretaria de Formação e Desenvolvimento Profissional (SEFOR), enfatizava que devem ser desenvolvidas nos alunos as habilidades de conhecimentos básicos, específicos e de gestão, visando "o desenvolvimento plural do indivíduo e o reconhecimento e a valorização dos saberes adquiridos por meio das experiências de trabalho, e seu credenciamento garantindo a possibilidade de reingresso no sistema educacional formal", e negava a dicotomia até então existente entre Educação Básica e Educação Profissional, (op. cit., p. 116).

Neste projeto, a Educação Profissional é vista como política pública, fazendo parte de um plano nacional de desenvolvimento econômico e tecnológico, ligados às políticas de emprego, trabalho e renda. As políticas do Ministério do Trabalho previam não só a descentralização das atividades, adotando recursos públicos, privados e externos, como também a articulação com várias entidades, passando dos sindicatos e Organizações Não-Governamentais, até as estruturas formativas do Sistema "S" e da rede pública.

O projeto do Ministério da Educação, por meio da Secretaria Nacional de Ensino Técnico (Senete), difundiu a proposta do Sistema Nacional de Educação Tecnológica. Segundo essa visão, era necessário que o Brasil ingres sasse em um desenvolvimento igual aos países do Primeiro Mundo, detentores de tecnologia de ponta. Kuenzer (1997) é uma forte opositora desse projeto, como destaca Manfredi, pois para alcançar esse patamar seria necessário termos uma sólida educação geral tecnológica, capaz de preparar profissionais para desenvolver e gerar tecnologia.

No que concerne a Sociedade Civil, Manfredi destaca os projetos provenientes dos educadores e de organizações populares e sindicais e os projetos dos empresários industriais. Os projetos da Sociedade Civil e das entidades de profissionais da educação, foram articulados no Fórum de Defesa da Escola Pública, como destacamos. Era um projeto avançado que "propunha a criação da escola básica unitária, sustentada pela justificativa de construção de um sistema de educação nacional integrado que propiciasse a unificação entre trabalho, ciência, tecnologia e cultura" (MANFREDI, id., p. 119-120).

Nessa forma de organizar a escola e o sistema de ensino, tanto a cultura quanto o trabalho, são fundamentais para a formação dos homens multilateralmente. Segundo essa proposta, a formação profissional, e suas diferen- 
tes especializações, ocorreriam depois da conclusão do ensino básico. Previase, também, a universalização do ensino público e gratuito para crianças e adolescentes com idade de frequentar a escola.

Manfredi destaca que os empresários brasileiros e suas entidades de representação: a CNI (Confederação Nacional da Indústria) e a FIESP (Federação dos Industriais do Estado de São Paulo), que pertencem aos setores mais dinâmicos e modernos da economia, enfrentaram vários embates. A partir de meados dos anos 1990, passaram a conviver "com desafios decorrentes dos processos de modernização produtiva e de globalização econômica" (op. cit., p. 122). Esses desafios podem ser constatados à medida que tiveram que reformar não só os sistemas de formação profissional, de que, historicamente, eles sempre se ocuparam, mas também lidar com a superação dos baixos níveis de escolaridade, presentes na sociedade brasileira, além de conviver com o "descompasso existente entre a formação geral propiciada pela escola e aquela exigida pelos processos de modernização produtiva e de globalização da economia" (op. cit., p. 123).

O projeto de reforma de ensino médio e profissional que foi implantado pelo governo, através do Decreto 2.208/97, no entanto, separou a formação acadêmica da Educação Profissional. A reforma da Educação Profissional imposta, ao estabelecer a separação entre o ensino médio e o profissional, gerando sistemas e redes distintas, provocou críticas contundentes. Kuenzer e Ferreti (1999), por exemplo, criticam a volta da dualidade estrutural e a ruptura entre o acadêmico e o tecnológico. A justificativa de redução de custos para essa posição é contestada pelos autores, pois ela não só compromete que os setores das classes populares tenham acesso ao ensino médio, como também elitiza o ensino, privatizando-o.

\section{3 - Educação dos Trabalhadores}

No Brasil, a educação dos trabalhadores é questão antiga em suas organizações. Segundo estudos de Manfredi (1986) em jornais sindicais, diversas categorias (alfaiates, gráficos, metalúrgicos, bancários) desde a década de 20 até meados dos anos 70 , contêm indicações de cursos, de breve duração com temática profissionalizante. A autora cita, por exemplo, a famosa escola proletária da União dos Trabalhadores Gráficos, existente na década de 1930, em São Paulo "que teve por mestres intelectuais brasileiros, como Azis Simão e Raquel de Queiroz" (MANFREDI, 2002, p. 242).

Com a ascensão do "sindicalismo oficial", no final da década de 1940 e início da década de 1950, os sindicatos organizaram escolas regulares de ensino primário, escolas técnicas de nível ginasial, cursos noturnos e outros. No período de 1962 a 1974, Manfredi destaca, também em São Paulo, atividades educativas mais sistemáticas, desenvolvidas nos sindicatos: cursos regulares de 
$1^{\circ}$. e $2^{\circ}$. Graus ${ }^{8}$, cursos profissionalizantes de curta duração e cursos especiais. Essas atividades eram realizadas através de convênios com órgãos competentes ligados ao Ministério do Trabalho, ou através de convênios com entidades oficiais - Serviço Nacional de Aprendizagem Industrial - Senai, Serviço Social do Comércio - Sesc e Serviço Social da Indústria - Sesi.

Destaca também que durante o período dos governos militares (principalmente entre 1968 e 1974) os cursos supletivos de $1^{\circ}$. e $2^{\circ}$. Graus, das entidades sindicais, "se transformaram em verdadeiros refúgios para alguns militantes de esquerda" (op. cit., p. 243). A apropriação e a manutenção do saber técnico pelo movimento operário brasileiro, constitui-se numa "bandeira histórica", na luta contra a "desqualificação e a expropriação do saber a que o capital o tem submetido" (op. cit., p 244). Depois do fim da Ditadura Civil-militar, a partir dos anos 1990, com as transformações técnicas e organizacionais decorrentes da reestruturação produtiva e da globalização, os trabalhadores e suas organizações passam a enfrentar outras questões referentes à formação profissional.

Durante as décadas de 1980 e 1990, o movimento sindical brasileiro, segundo Manfredi, passou a ter um papel mais ativo, não só fazendo propostas de políticas públicas, como também tornando-se agentes formadores. Esse processo é proveniente das transformações econômicas, sociais e políticas, ocorridas com a internacionalização da economia. Em 1996, com a liberação dos recursos do FAT (Fundo de Amparo ao Trabalhador), através do PLANFOR (Plano Nacional de Qualificação de Trabalhador), do Ministério do Trabalho, as centrais sindicais passaram a desenvolver programas de âmbito nacional.

Manfredi destaca as iniciativas das três principais centrais sindicais brasileiras: CUT (Central única dos Trabalhadores), FS (Força Sindical) e CGT (Comando Geral dos Trabalhadores). São experiências diferenciadas e desiguais, relativas às concepções, às propostas político-pedagógicas, aos programas e grupos sociais a serem atingidos. Ao analisar as concepções e propostas das três centrais sindicais, Manfredi destaca alguns pontos de convergência e outros de distanciamento.

A CUT, por exemplo, prevê que o acesso à educação é um direito social e um dever do Estado. Segundo essa visão, ela deve contribuir criticamente para a construção de uma contra hegemonia ao projeto neoliberal. Fazendo um contraponto, Manfredi destaca que, no entanto, "as três centrais defendem a articulação entre a educação básica e a formação profissional e destas com as políticas de emprego" (op. cit., p. 279). Quanto à necessidade de mudanças político-estruturais, a CGT é menos enfática que a CUT. A Força Sindical, por sua vez, propõe metas para elevar o nível de escolaridade e qualificação profis -

\footnotetext{
${ }^{8}$ Essas iniciativas iniciam-se antes da Ditadura, em 1964, e prosseguem durante o regime ditatorial (1964-1985). Estende-se da vigência da LDBEN (Lei de Diretrizes e Bases da Educação Nacional), Lei n. 4.024/61 à Lei do Ensino de $1^{\circ}$. e $2^{\circ}$. Graus, Lei n. 5.672/71.
} 
sional dos trabalhadores, envolvendo o empresariado, o governo e a sociedade civil organizada.

O trabalho de Manfredi, na recuperação de fontes, ao registrar como se desenvolveu a Educação Profissional no movimento sindical, durante as décadas de 1980 e 1990, busca demonstrar o processo de participação crescente das centrais sindicais, e possibilita compreender o papel das organizações de trabalhadores como protagonistas da formação profissional em um período importante da história da Educação Profissional no Brasil.

O momento se expressa em um campo de disputas das concepções e práticas, onde se situa o domínio do saber operacional e técnico dos trabalhadores e, concomitantemente, onde ocorre o enfrentamento das novas estratégias que servem ao domínio do capital, sobre o trabalho coletivo. A institucionalização dos projetos educativos pelas organizações de trabalhadores está situada no espaço de algumas contradições, mas tais questões não se expressam nesse estudo, salvo quando a autora sinaliza que "Embora revelem tensões e contradições entre o discurso manifesto mediante seus documentos e as práticas concretas [...] tais experiências constituem verdadeiros laboratórios no campo da educação de jovens e adultos" (id., p. 283-84).

\subsection{Movimentos Sociais e Educação}

Ao fazer a retrospectiva histórica da Educação Profissional no Brasil, Manfredi observou as políticas e iniciativas desenvolvidas ao longo do tempo para promover a formação dos trabalhadores. As relações de aproximação e distanciamento entre Estado e sociedade civil, referem-se a um espaço não homogêneo em que se situam grupos movidos por diversos ideários políticoideológicos, e onde se estabelece a disputa entre hegemonia e contra hegemonia, e se expressam muitas contradições.

É esse movimento da história que a autora tenta captar no capítulo IV, ao tratar da educação profissional e as entidades da sociedade civil. Centrase nas ONGs (Organizações Não-Governamentais), também nominados de Terceiro Setor, por suas propostas inovadoras e de criação de espaços e projetos de formação profissional. A autora apresenta e justifica a escolha do Projeto do MST (Movimento dos Trabalhadores Sem Terra) e o Projeto AXÉ no seu recorte de estudo. Os projetos selecionados não são comparados e a análise não se detém nas diferenças políticas, porém ambos os projetos englobam uma perspectiva de intervenção crítica, em realidades sociais distintas onde a desigualdade e injustiça são as tônicas. Em pauta, está a luta pela terra, a educação no campo e a luta pela sobrevivência nas periferias urbanas.

Manfredi recupera a origem das ONGs e os conceitos que as fundamentam, discorrendo sobre sua constituição e sua forma de atuação na esfera pública, baseada e outros autores. Enfoca o crescimento da participação das ONGs na Educação Profissional a partir dos anos 1990, quando se inicia o 
PLANFOR com as verbas do FAT. Mas destaca a opção por um modelo de desenvolvimento baseado nos padrões neoliberais, motivo pelo qual o mercado de trabalho se tornou cada vez mais restrito, competitivo e o Terceiro Setor cresceu. Ao descrever a classificação de Gohn (1997), apresenta as ONGs atuantes no Brasil a partir dos anos 1990, a saber: ONGs caritativas, ONGs desenvolvimentistas, ONGs cidadãs e ONGs ambientalistas ou ecológicas.

$\mathrm{Na}$ última década, as ONGs passaram a integrar a rede nacional de formação profissional, recebendo, inclusive, recursos públicos passando a atuar de modo sistemático em Programas de Educação Profissional através do PIANFOR. Porém, existem ONGs que tem recursos próprios e/ou recebem recursos de fundações privadas, nacionais e internacionais, a exemplo da Fundação Ayrton Senna, Fundação Itaú, Unicef, Anistia Internacional, ONU (Organização das Nações Unidas), UNICEF (Organização das Nações Unidas para a Infância).

Nas ONGs, segundo a ABONG (Associação Brasileira de Organizações Não-Governamentais) as atividades formativas, em grande parte, estão relacionadas a formação e são destinadas a "grupos sociais com pouca ou nenhuma oportunidade de acesso aos programas oficiais e convencionais de formação profissional" (MANFREDI, id., p. 215). São experiências ligadas ao "trabalho cooperativo e/ou à produção associada, ao desenvolvimento comunitário, à formação para serviços no campo da educação, da saúde, da segurança pública, ao conhecimento dos direitos de cidadania e ao exercício de atividades de representação político-social” (p. 215).

No âmbito do Planfor são denominadas "experiências inovadoras" e fica explícito que não se coadunam com a preparação/formação para as necessidades do mercado. Ao contrário, segundo Manfredi, pensam a "educação e a educação profissional como um direito advindo da necessidade de (com)vivência social, numa sociedade complexa e desigual como a brasileira" (id., p. 216).

Por compreender a grande diversidade de experiências e a impossibilidade de abordá-las analiticamente, naquela publicação, a autora optou por dois projetos que estão acumulando experiências há mais de uma década e estão direcionados para dois segmentos sociais, os trabalhadores rurais e as crianças e adolescente em condição de rua. Assim, os dois projetos premiados pela Unesco e Unicef, o Projeto do MST e o Projeto Axé foram definidos para o estudo.

$\mathrm{Na}$ análise de sua escrita sobre o Projeto do MST, percebemos o caráter contra hegemônico da proposta, prezando a formação de intelectuais orgânicos, participantes ativos como dirigentes na intervenção social de ocupação, de resistência, de produção da terra, em oposição ao latifúndio. A autora recupera brevemente o histórico do Movimento, o que auxilia o leitor a compreender o projeto ampliado do MST que não é só de formação, mas de construção de um movimento de massas de caráter nacional, uma organização so- 
cial na luta por um novo projeto de desenvolvimento para o Brasil. Segundo Manfredi,

[...] pode-se perceber que, no MST, a educação é entendida como um processo de formação e de transformação humana, que se dá simultaneamente mediante a participação no movimento e em ações e práticas (de escolarização e/ou outras ações coletivas) educativas intencionalmente planejadas (MANFREDI, 2002, p.223).

Na sequência do texto, quando a autora aborda o Projeto AXÉ ${ }^{9}$ constatamos seus objetivos de inclusão social de crianças e adolescentes. Como existe uma carência de oportunidades nesses segmentos da sociedade, talvez se justifique o fato do projeto estar atrelado à construção da identidade social como novo instrumento da política de consenso.

Inicialmente, o Projeto Axé estava ligado ao Movimento Nacional de Meninos e Meninas de Rua, afirmando-se como "herdeiro das lutas de afirmação dos direitos e da cidadania das crianças e adolescentes brasileiros". Atualmente se constitui como uma ONG autônoma, como foi observado pela autora no levantamento dos eixos estruturantes, é um projeto político-pedagógico que se antagoniza com a "orientação assistencialista no campo da atuação com menores e vem defendendo uma linha crítica e profissional de atuação" (p. 227-28). As convicções e pressupostos que o alicerçam também foram expostos por Manfredi, dando uma visão das referências estruturantes do Projeto. Baseia-se na cultura, na arte, na política, nos direitos humanos, na construção da cidadania, sempre considerando que esses meninos e meninas de rua são portadores de cultura, e, "a cultura é um espaço de afirmação identitária, étnica, comunitária", com espaço para a psicanálise como referencial teórico (CAPPI, 2000, apud MANFREDI, id. p. 231-32).

Ao concluir sua abordagem das duas propostas selecionadas, Manfredi nos presenteia com exemplos historicizados de ações educacionais que estão na pauta das ações contra hegemônicas, que dizem respeito à formação humana, referendadas por princípios éticos, políticos e culturais, dimensões formativas que não se restringem à mera preparação para o ingresso, a manutenção e a reinserção de mão-de-obra no mercado de trabalho.

\section{Considerações finais}

A pesquisa historiográfica desenvolvida por Manfredi nos permite entender algumas mediações presentes na Educação Profissional no Brasil, tendo como fundamentação teórica o pensamento marxista. O grande diferencial, a nosso ver, do trabalho da autora, é não só a pesquisa dos parâmetros legais,

\footnotetext{
9 "A palavra 'axé', do candomblé baiano, significa princípio vital, a energia que permite que todas as coisas existam" (id., p. 227).
} 
como também a inclusão de diversos sujeitos nos seus variados espaços sociais: sindicatos, empresas, associações de bairro, associações comunitárias e movimentos sociais. Não podemos deixar de ressaltar que esse tipo de investigação, sobre o tema em questão, é recente na nossa história.

Manfredi teve uma participação ativa nos partidos políticos e em movimentos sociais que lutaram contra a Ditadura Militar que se instalou no Brasil de 1964 a 1985. Sua trajetória acadêmica inclui também o trabalho de educação nos sindicatos e s pesquisa em educação popular. Ela recupera experiências e práticas da educação sindical e de outras agentes sociais no Brasil. Outro ponto importante a destacar no seu trabalho, é a visão crítica que traz de vários teóricos sobre o tema, junto a aspectos culturais, sociológicos, políticos, filosóficos e econômicos. Sua pesquisa está vinculada à sua trajetória pessoal e profissional.

Ao longo do trabalho, vai desenvolver o conhecimento das relações sociais entre o trabalho e a educação são mais complexas do que é propagado pelo senso comum. Trabalha com algumas categorias para explicar as múltiplas determinações entre trabalho, emprego, profissão, profissionalização, escola, escolarização. Destaca que o trabalho é a base para a estruturação das categorias socio-profissionais, sendo por isso, objeto de ação e intervenção de políticas governamentais.

Constata que no Brasil, no século XX, a partir da década de 1990, ocorre uma diferenciação no discurso sobre trabalho, emprego e educação, que é muito mais dependente de questões estruturais do que de processos educativos. Destaca ainda, as bases econômicas para a reforma de ensino profissionalizante, após a LDB (Lei n. 9.394/96) e a separação entre o ensino médio da educação profissional (Decr. Fed.al n. 2.208/97). Nesta etapa, são diversos protagonistas que defendem os seus projetos: trabalhadores, empresários e governo. A autora ressalta também alguns autores críticos ao projeto de reforma de ensino médio e profissional, implantado pelo governo federal de Fernando Henrique Cardoso.

Manfredi pesquisa também a Educação Profissional nas organizações de trabalhadores, trazendo as contribuições das três principais centrais sindicais e seus pontos de convergência e distanciamento: a CUT, a FS e a CGT.

Ao se referir as concepções e práticas de Educação Profissional dentro da sociedade civil, destaca que elas não são homogêneas, pois possuem ideologias e políticas distintas; umas estão ligadas a grupos dominantes, e outras articuladas a projetos de resistência para a elaboração de propostas alternativas.

Precisamos entender a dimensão multicultural e étnica das diferentes formas de trabalho que foram, historicamente, se construindo no Brasil (BLASS, 2000). Logo, podemos concluir que, quanto à natureza da Educação Profissional no Brasil, há uma fragmentação e diferenciação de expectativas, a partir dos diferentes interesses em jogo. Precisamos entender qual são as pers- 
pectivas e projetos, analisando qual é o lugar social de onde se origina a educação profissional, identificando diferentes interesses e iniciativas.

O trabalho historiográfico de Manfredi estrutura a Educação Profissional no Brasil compreendendo um período histórico longo, situado para além das instituições públicas de ensino, abordando a mobilização de educadoressindicalistas e de outros sujeitos sociais que acreditam em uma intervenção política fundada na educação emancipatória, em contraposição à educação instrumental voltada para os interesses do capital. A mundialização do capital, as mudanças da base técnica e organizacional das empresas, a substituição do trabalhador pela automação, entre outros fatores, evoca a importância estratégica do projeto destinado à educação dos trabalhadores.

Como admite a autora, dois aspectos relevantes devem ser considerados na análise de sua obra. O primeiro refere-se à sua abordagem histórico social crítica, onde descreve o campo da educação profissional como um espaço de lutas entre sujeitos sociais. O segundo refere-se à dimensão política de seu trabalho, à sua posição política, social e pessoal como forma de salvaguardar a história das políticas públicas da educação profissional no passado recente.

É amplo o trabalho de pesquisa apresentado por Manfredi. Sua elaboração teve por base fontes primárias, seleção e uso das categorias mais adequadas ao tratamento do tema educação profissional em entidades da sociedade civil, como as organizações de trabalhadores. Podemos concluir que, com seu trabalho, a história da educação profissional herda outro olhar. É o olhar que dialoga com diferentes instituições, com novas formas de educar, com projetos constituídos em outros segmentos, com iniciativas contra hegemônicas, com a pluralidade que confere a esta publicação diversas possibilidades de reflexão sobre temas que nos são tão caros, como é a educação da classe trabalhadora. 



\section{REFERÊNCIAS BIBLIOGRÁFICAS}

ABBAGNANO, Nicola. Dicionário de filosofia. São Paulo: Editora WMF Martins Fontes, 2012.

AKOUN, André (dir.) La Philosophie. Paris: CEPL, 1977.

ALVES, Cláudia M. C. Acervos Bibliográficos para a História da Educação. Niterói: EDUFF, 2001.

ALVES, Cláudia M. C. Estado conservador e educação no Brasil: o caso do Liceu Provincial de Niterói (1847-1851). In: NUNES, Clarice. O passado sempre presente. São Paulo: Cortez, 1992, p. 43-68.

ALVIM, Maria Rosilene B; VALADARES, Lísia do D. Infância e sociedade no Brasil: uma análise de literatura. BIB, Rio de Janeiro, n. 26, p. 3-37, 2. Sem. 1988.

ANDREOTTI, Azilde L. Acervo de Fontes de Pesquisa para a História da Educação Brasileira: características e conteúdo, 2005. Disponível em: $<\underline{w w w}$.histedbr.fae.unicmap.br>. Acesso em: 15 jul.2019.

ANTUNES, Ricardo. Os sentidos do trabalho: ensaio sobre a afirmação e a negação do trabalho. São Paulo: Boitempo Editorial, 2000.

ATTALI, Jacques. Historias del tempo. México: Fondo de Cultura Económica, 1985.

BATALHA, Cláudio. A historiografia da classe operária no Brasil: trajetória e tendências. In: FREITAS, Marcos Cezar de. Historiografia brasileira em perspectiva. São Paulo: Contexto, 1998, p. 145-158.

BATISTA, Eraldo L. Trabalho e educação profissional nas décadas de 1930 e 1940 no Brasil. Campinas: Autores Associados, 2015.

BELLUZZO, Luiz G. de Mello. Prefácio. In: MELLO, João Cardoso de. O capitalismo tardio. 4. ed. São Paulo: Brasiliense, 1986.

BENJAMIN, Walter. Obras escolhidas. Magia e técnica, arte e política. 3. ed. São Paulo: Brasiliense, 1987.

BENTIVOGLIO, Júlio. Apresentação. In: DROYSEN, Joahan Gustav. Manual de teoria da história. Petrópolis: Vozes, 2009.

BERGER, Peter e LUCKMANN, Thomas. A Construção Social da Realidade. Petrópolis: Vozes, 1973.

BERGSON, H. Matière et Mémoire. Paris: PUF, 1990

BLASS, Leila M. da Silva. A formação multicultural do trabalhador assalariado brasileiro: o invisível pertinente. São Paulo: PUC, 2000, Mimeografado.

BLOCH, Marc. Apologia da história ou O ofício do historiador. Rio de Janeiro: Jorge Zahar, 2001.

BOBBIO, Norberto, MATTEUCCI, Nicola, PAQUINO, Gianfranco. Dicionário de Política. Brasília: Editora Universidade de Brasília, 1993.

BOSI, Alfredo. Literatura e resistência. São Paulo: Companhia das Letras, 2002.

BOURDIEU, Pierre; WACQUANT, Loic. A nova bíblia do Tio Sam. Jornal Le Monde diplomatique. Edição brasileira, ano 1, n. 4., ago. 2000. 
BRAGA, Ana Beatriz. A construção social da infância trabalhadora na Primeira República. 1993. 169 f. Dissertação (Mestrado em Sociologia) - Instituto de Ciências Sociais, Universidade Federal do Rio de Janeiro, Rio de Janeiro, 1993.

BRANCO, Guilherme C. As resistências ao poder em Michel Foucult. Trans;Form/ Ação, São Paulo, 24, p. 237-248, 2001.

BRASIL. Decreto 1313 - Proíbe trabalho de menores de 12 anos, Rio de Janeiro, 1891.

BRAUDEL, Ferdinand. A longa duração. In: História e ciências sociais. Lisboa: Editorial Presença, 1982.

BRAUDEL. Ferdinand. A dinâmica do capitalismo. Rio de Janeiro: Rocco, 1987. BRETAS, Marcos Luiz. Ordem na cidade. O exercício cotidiano da autoridade policial no Rio de Janeiro: 1907-1930. Rio de Janeiro: Rocco, 1997.

BURKE, Peter (org.). A Escrita da História: novas perspectivas, São Paulo: Ed. da Universidade Estadual Paulista, 1992.

BURKE, Peter. A Escola des Annales. 1929-1989. A revolução francesa da historiografia. São Paulo: UNESP, 1991.

CADIOU, François et al. Como se faz a história. Historiografia, método e pesquisa. Petrópolis: Vozes, 2007.

CAETANO, C. G. Qualificação e ferrovias: a experiência das Escolas Profissionais Ferroviárias (1920-1945). In: M. A. R. Ribeiro (Org.). Trabalhadores urbanos e ensino profissional. Campinas, SP: Unicamp, 1986, p. 225-308.

CALAZANS, Maria Julieta Costa. ANPED - Trajetória da Pós-Graduação e Pesquisa em Educação no Brasil. Documentos ANPED, set. 1995.

CARDOSO, Ciro Flamarion. Ensaios racionalistas. Rio de Janeiro, Campus, 1988.

. Uma introdução à história. São Paulo: Brasiliense, 1986.

. (Org.) Escravidão e abolição no Brasil: novas perspectivas. Rio de Jane:

Zahar, 1988.

Escravo ou camponês? São Paulo, Brasiliense, 1987.

CARDOSO, Ciro Flamarion; VAINFAS, Ronaldo. Domínios da história. Rio de Janeiro: Campus, 1997.

CARDOSO, Irene. Narrativa e história. Com o Bruni, a experiência de uma amizade.

Tempo Social, Revista de Sociologia da USP, São Paulo, v. 12, n. 2, p. nov. 2000.

Disponível em: $<$ http://www.scielo.br/scielo.php?script=sci $\operatorname{arttext\& pid=S0103-}$ 20702000000200002 >. Acesso em: 27 abr. 2017.

CARNEIRO, Sueli. Entrevista. Margem Esquerda, v. 27, São Paulo, Boitempo, 2016.

CARONE, Edgard. A República Velha: evolução política. Coleção Corpo e Alma do Brasil. São Paulo: Difusão Europeia do Livro, 1974.

CARVALHO, José M. de. Os bestializados: o Rio de Janeiro e a República que não foi. São Paulo: Companhia das Letras, 1987.

CARVALHO, Marcus J. M. de. Liberdade: rotinas e rupturas do escravismo no Recife, 1922-1850. Recife: Editora Universitária da UFPE, 1998. 
CASADEI, Eliza Bachega. Maurice Halbwachs e Marc Bloch em torno do conceito de memória coletiva. Revista Espaço Acadêmico, n. 108, maio de 2010. Disponível

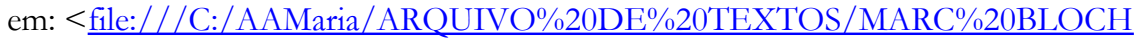
\%20e\%20HALBWACHS\%20-\%20art.\%20sobre.pdf >. Acesso em: 21 abr. 2018.

CASTEL, Robert. As armadilhas da exclusão. WANDERLEY, Mariangela Belfiore; BÓGUS, Lucia; YAZBEK, Maria Carmelita. Desigualdade e a questão social. São Paulo: EDUC, 1997.

CASTRO, Hebe M. M. de; SCHNOOR, Eduardo (Org.) Resgate - uma janela para o oitocentos. Rio de Janeiro: Topbooks, 1995.

CASTRO, Hebe M. M. de. Das cores do silêncio: os significados da liberdade no sudeste escravista - Brasil século XIX. Rio de Janeiro, Arquivo Nacional, 1995.

CENAFOR. Experiências e perspectivas sobre Escolas de Produção no meio urbano no Brasil. São Paulo: CENAFOR, 1982.

CERTEAU, Michel de. A escrita da História. Rio de Janeiro: Forense, 1982.

CHALHOUB, Sidney ; SILVA, Fernando T. Sujeitos no imaginário acadêmico: escravos e trabalhadores na historiografia brasileira desde os anos 1980. Cadernos AEL, v.14, n.26, p. 11-50, 2009.

CHALHOUB, Sidney. Trabalhadores Classes Perigosas. In: Trabalhadores VI, Campinas: Prefeitura Municipal de Campinas, 1990.

. Trabalho, lar e botequim: O Cotidiano dos trabalhadores do Rio de Janeiro da Belle Èpoque. São Paulo, Brasiliense, 1986.

. Visões de Liberdade: uma história das últimas décadas da escravidão na Corte. São Paulo: Cia das Letras, 1990.

CIAVATTA, Maria Franco (org.). Estudos comparados em educação: uma discussão teórico-metodológica a partir da questão do outro. In:

e educação na América Latina. São Paulo: Livros do Tatu, 1992.

. A escola do trabalho: história e imagens. 1993. 286 f. Tese (Professor Titular)- Universidade Federal Fluminense, Niterói, 1993.

O trabalho como princípio educativo. Uma investigação teórico-metodológica (1930-1960). 1990. Tese (Doutorado em Ciências Humanas - Educação) Departamento de Educação, Pontifícia Universidade Católica do Rio de Janeiro, Rio de Janeiro, 1990.

. A historicidade da pesquisa em educação: desafios teórico-metodológicos em trabalho e educação. In: MOURA, Dante Henrique. (Org.). Educação Profissional: desafios teórico-metodológicos e políticas públicas. Natal: IFRN, 2016a, v. 01, p. 13240.

A reconstrução histórica de trabalho e educação: um estudo sobre suas categorias. Trabalho apresentado no VII Congresso Luso-brasileiro de História da Educação, Universidade de Lisboa, 12 a 15 de julho de 2012b.

Mediações históricas de relação trabalho e educação. Gênese da disputa na formação dos trabalhadores (1930-1960). Rio de Janeiro: Lamparina / CNPq / FAPERJ, 2009. 
. O trabalho docente e os caminhos do conhecimento. A historicidade da Educação Profissional. Rio de Janeiro: Lamparina, 2015.

. (coord.) Memória e temporalidades do trabalho e da educação. Rio de Janeiro: Lamparina / FAPERJ, 2007.

. A cultura material escolar em trabalho e educação. A memória fotográfica de sua transformação. Educação e Filosofia. Uberlândia, v. 23, n. 46, p. 37-72, jul./dez. 2009.

A historicidade da pesquisa em Educação Profissional. XI Congreso Iberoamericano de Historia de la Educación de Latinoamérica, Toluca, México, 6 a 9 de mayo de 2014 (digital e impresso).

A historiografia em Trabalho e Educação e o Pensamento Crítico. Como se escreve a história da educação profissional. Projeto de Pesquisa (CNPq, 2013-2018). Rio de Janeiro, 2012 (Impresso e digital).

. A produção do Conhecimento Sobre a Configuração do Campo da Educação Profissional e Tecnológica. Holos (Natal. Online), v. 6, p. 33 - 49, 2016.

Aspectos teóricos de la producción científica del Grupo de Trabajo "Trabajo y Educación” en Brasil. Educa@UPN.MX / Revista Universitaria, v. 22, p. 1-21, 2017b.

Como se escreve a história de trabalho-educação. Caminhos para a historiografia. Niterói: UFF, 2017a (impresso e digital).

CIAVATTA, Maria; RAMOS, Marise. Ensino Médio e Educação Profissional no Brasil: dualidade e fragmentação. Revista Retratos da Escola, Brasília, v. 5, n. 8, p. 27 41, jan./jun. 2011.

CIAVATTA, Maria. Formação profissional para o trabalho incerto. In: FRIGOTTO, Gaudêncio. Educação e crise do trabalho: perspectivas de final de século. Petrópolis: Vozes, 1998.

. Historiografia em trabalho e educação - Como se constroem as categorias. Projeto de Pesquisa (CNPq, 2008-2011). Niterói, UFF, 2007.

O conhecimento histórico e o problema teórico metodológico das mediações. 1. ed. In: FRIGOTTO, Gaudêncio ; CIAVATTA, Maria. Teoria e educação no labirinto do capital. Petrópolis: Vozes, 2001.

O conhecimento histórico e o problema teórico-metodológico das mediações. In: FRIGOTTO, Gaudêncio; CIAVATTA, Maria (orgs.). Teoria e educação no labirinto do capital. 4. ed. São Paulo: Expressão Popular, 2014, p. 207-246.

O mundo do trabalho em imagens. A fotografia como fonte histórica (Rio de Janeiro, 1900-1930). Rio de Janeiro: DP \& A, 2002.

O trabalho docente e os caminhos do conhecimento: a historicidade da Educação Profissional. Rio de Janeiro: Lamparina, 2015.

CIAVATTA, Maria; GONTIJO, Rebeca; FONSECA, Celso Suckow da. In: FÁVERO, Maria de Lourdes de Albuquerque; BRITTO, Jader de Medeiros (orgs.). Dicionário de Educadores no Brasil: da Colônia aos dias atuais. 2. ed. Aumentada. Rio de Janeiro: Editora UFRJ \& MEC/INEP/COMPED, 2002. 
CIAVAT'TA, Maria; REIS, Renata. O passado escravista no presente: a sociologia histórica de Luiz Antônio Cunha. Revista HistedBR On-Line, Campinas, n. 70, p. 7086, dez. 2016.

CIAVATTA, Maria; SILVEIRA, Zuleide Simas. Celso Suckow da Fonseca. Recife: Fundação Joaquim Nabuco, Editora Massangana, 2010.

COMPARATO, Fábio Konder. A oligarquia brasileira. Visão histórica. São Paulo: Contracorrente, 2017.

CUEVA, Agustin. El virage conservador: señas y contraseñas. In: (org.). Tiempos conservadores. América Latina en la derechización de Occidente. Quito: El Conejo, 1987.

CUNHA, Luiz A. O ensino de ofícios artesanais e manufatureiros no Brasil escravocrata. São Paulo: UNESP; Brasília: FLACSO, 2000a.

O ensino de ofícios nos primórdios da industrialização. São Paulo:

UNESP; Brasília: FLACSO, 2000b.

A universidade crítica. 3. ed. São Paulo: Editora da UNESP, 2007.

Ensino médio e ensino técnico: de volta ao passado? Educação e Filosofia, v. 12, no. 24, p. 65-69, jul./dez. 1998.

. O ensino industrial-manufatureiro no Brasil. Revista Brasileira de Educação, São Paulo, n. 14, mai/jun./jul./ago., 2000d, p. 89-107.

O ensino profissional na irradiação do industrialismo. São Paulo:

UNESP; Brasília: FLACSO, 2000c.

Política educacional no Brasil: a profissionalização do ensino médio. Rio de Janeiro: Eldorado, 1973.

DECCA, Edgar de. 1930. O silêncio dos vencidos. São Paulo: Brasiliense, 1984.

DEREYMES, Jean- William. Le Travail-Histoire, perspectives. Grenoble: Presses Universitaires de Grenoble, 1995.

ELIAS, Norbert. Sobre o tempo. Rio de Janeiro: Jorge Zahar, 1998.

ENGUITA, Mariano F. A face oculta da escola. Porto Alegre: Artes Médicas, 1989.

FALCON, Francisco J. C. História cultural e história da educação. Revista Brasileira de Educação, v. 11, n. 32, p. 328-339, maio/ago. 2006.

FARIA FILHO, Luciano Mendes de. República, Trabalho e Educação: A experiência do Instituto João Pinheiro 1909/1934. Bragança Paulista: Editora da Universidade São Francisco, 2001.

FARIA FILHO, Luciano Mendes; ARAÚJO, Vânia de Carvalho. História da Educação e da Assistência à Infância no Brasil. Vitória: EDUFES, 2011.

FARIA, Sheila de Castro. Escravidão e relações familiares no Rio de Janeiro. In: Estudos sobre a escravidão II. Cadernos do ICHF, Niterói, n.23, ago/1990.

FÁVERO, M. de L. A. "O pesquisador e o desafio das fontes”. In: MENDONÇA, Ana W.C.P. et al. História da educação. Desafios históricos e empíricos. Niterói: EDUFF, 2009. 
FERREIRA, Marieta de M.; AMADO, Janaína (org.). Usos \& Abusos da História Oral. 8. ed. Rio de Janeiro: Editora FGV, 2006.

FONSECA, Celso S. da. História do Ensino Industrial no Brasil. v. 5. Rio de Janeiro: SENAI/DN, 1986.

FONTANA, Josep. A história dos homens. Bauru, SP: EDUSC, 2004.

História depois do fim da história. Bauru, SP: EDUSC, 1998.

FONTES, Virgínia. História e verdade. In: FRIGOTTTO, Gaudêncio; CIAVATTA, Maria (orgs.). Teoria e educação no labirinto do capital. 2. ed. São Paulo: Expressão Popular, 2014, p.167-189.

FOUCAULT, Michel. O sujeito e o poder. In: RABINOW, Paul e DREYFUS, Hubert. Michel Foucault - Uma trajetória filosófica. Para além do estruturalismo e da hermenêutica. Rio de Janeiro: Forense Universitária, 1995.

FRAILE, Guillermo Fr. Historia de la Filosofia. I. Grecia y Roma. Madrid: Editorial Católica, 1956.

FREYRE, Gilberto. Casa Grande e senzala. 35. ed. Rio de Janeiro: José Olympio, 1982.

FRIGOTTO, Gaudêncio. A produtividade da escola improdutiva. Um (re)exame das relações entre educação e estrutura econômico-social capitalista. São Paulo: Editora Cortez, 1984.

Educação e a crise do capitalismo real. São Paulo: Cortez, 1994.

Educação e trabalho. Boletim da ANPEd, 11'a Reunião Anual, UFRGS,

Porto Alegre, 25 a 29 de abril de 1988, v. 10, n. 2-3, abril-setembro 1988, p. 25.

Fazendo pelas mãos a cabeça do trabalhador: o trabalho como elemento pedagógico na formação profissional. Cadernos de Pesquisa, n. 47, p. 38-45, nov, 1983.

Fundamentos científicos e técnicos da relação Trabalho e Educação no Brasil de hoje. In: LIMA, Júlio César França; NEVES, Lúcia Maria Wanderley (Orgs.). Fundamentos da educação escolar do Brasil contemporâneo. Rio de Janeiro: Editora FIOCRUZ, 2006, 320 p.

Trabalho como princípio educativo; por uma superação das ambiguidades.

Boletim Técnico do SENAC, Rio de Janeiro, v. 11, n. 3, p. 175-182, set. dez. 1985.

FRIGOT'TO, Gaudêncio; CIAVATT'TA, Maria. Trabalho como princípio educativo. In: CALDART, Roseli et al. Dicionário da Educação do Campo. São Paulo: Expressão Popular, 2012.

FRIGOTTO, Gaudêncio; CIAVATTA, Maria; RAMOS, Marise (orgs.). Ensino Médio Integrado - concepções e contradições. São Paulo: Cortez, 2005.

GITAHY, M. L. C. Qualificação e urbanização em São Paulo: a experiência do Liceu de Artes e Ofícios, 1873-1934. In: RIBEIRO, M. A. R. (Org.). Trabalhadores urbanos e ensino profissional. Campinas: Unicamp, 1986. p. 24-27. 
GÓES, José Roberto de; FLORENTINO, Manolo. Crianças escravas, crianças dos escravos. In: PRIORE (Org.) História das crianças no Brasil. São Paulo, Contexto, 1999, p.177-191.

GRAMSCI, Antônio. “O Conceito de Ideologia”. Obras Escolhidas. São Paulo: Martins Fontes, 1978b.

Cadernos do Cárcere. Caderno 12. v. 2. (Os intelectuais. O princípio educativo. Jornalismo). 4. ed. Rio de Janeiro: Civilização Brasileira, 2006.

L'Ordine nuovo (1919-1920). Torino: Einaudi, 1975.

La alternativa pedagógica. Barcelona: Fontamara, 1981.

Obras escolhidas. Lisboa: Martins Fontes, 1978.

GUIDO, Humberto; SAHAD, Luiz E. N. de A e S. Tempo e história no pensamento ocidental. Ijuí: Editora Unijuí, 2006.

HARVEY, David. A produção capitalista do espaço. São Paulo: Annablume, 2005.

Condição pós-moderna. Uma pesquisa sobre as origens da mudança cultural. 5. ed. São Paulo: Loyola, 1992.

Reflexões sobre "O capital” de Thomas Piquetty. Disponível em:

$<$ https://blogdaboitempo.com.br/2014/05/24/harvey-reflexoes-sobre-O-capital-dethomas-piketty/> Acesso em: 09 mar. 2017

HARVEY, David. Space as a keyword. In: CASTREE, N. e GREGORY, D. (org.).

David Harvey: a critical reader. Malden e Oxford: Blackwell, 2006. Tradução livre:

Letícia Gianella. Disponível em: < file:// C:/Users/Maria\%20Ciavatta/Downloads/ 551-1879-1-PB\%20(2).pdf>. Acesso em: 27 abr. 2017.

HOBSBAWM, E. Marxismo y história social. Puebla: Instituto de Ciencia de la Universidad Autónoma de Puebla, 1983.

Mundos do Trabalho. Rio de Janeiro: Paz e Terra, 1987.

IAMAMOTO, Marilda Villela. Serviço social em tempo de capital fetiche: capital financeiro, trabalho e questão social. São Paulo: Cortez, 2007.

JANOTTI, Maria de Lourdes. O livro Fontes Históricas como fonte. In: PINSKY, Carla Bassanezi. Fontes Históricas. Contexto, São Paulo, 2008.

O livro Fontes Históricas como fonte. In. PINSKY, Carla B. (org.). Fontes

Históricas. 2. ed. São Paulo: Contexto, 2006.

JAPIASSÚ, Hilton; MARCONDES, Danilo. Dicionário básico de filosofia. 3. ed. Rio de Janeiro: Jorge Zahar, 1996.

KAREL, Kosik. Dialética do concreto. Rio de Janeiro: Paz e Terra, 1976. (p. 7-68).

KONDER, Leandro. O marxismo na batalha das ideias. Rio de Janeiro: Nova Fronteira, 1984.

KOSELLECK, Reinhardt. Uma história dos conceitos: problemas teóricos e práticos.

Revista Estudos Históricos, CPDoc/FGV, v. 5, n. 10, p. 134-146, 1992.

KOSIK, Karel. Dialética do concreto. Rio de Janeiro: Paz e Terra, 1976.

KUENZER, Acácia Z.; FERRETI, Celso João. Políticas Públicas referentes à formação profissional no Brasil. IN: SILVA JÚNIOR, João dos Reis; OLIVEIRA, Maria Rita (Org.). Trabalho, formação e currículo. São Paulo: Xamã, 1999. 
KUENZER, Acácia Z. Ensino de $2^{\circ}$. Grau: o trabalho como princípio educativo. São Paulo: Cortez, 1988.

Ensino Médio e Profissional: as políticas do Estado Neoliberal. São Paulo: Cortez, 1997, (Questões de nossa época).

LARA, Silvia H. Trabalhadores Escravos. In: Trabalhadores I, Campinas: Prefeitura Municipal de Campinas, 1989.

LE GOFF, Jacques. História e memória. Campinas: Editora da Unicamp, 1992.

História e memória. Campinas: Editora da Unicamp, 1996.

LIMA, Marcelo. A história da educação profissional. Os passos e descompassos históricos do SENAI-ES com os paradigmas da produção industrial no Espírito Santo 1948-1989. Vitória: O Autor, 2007.

LOBO, Eulália M. et al. Evolução dos preços e do padrão de vida no Rio de Janeiro, 18201930. Revista Brasileira de Economia, Rio de Janeiro, v. 25, n. 4, out. dez. 1971.

LOMBARDI, J. C. História e historiografia da educação: atentando para as fontes. In: LOMBARDI, José Claudinei e NASCIMENTO, Maria Isabel Moura (Orgs.). Fontes, história e historiografia da educação. Campinas, SP: Autores Associados; HISTEDBR; Curitiba, PR: PUC-PR; Palmas, PR: UNICS) Ponta Grossa, PR: UEPG, 2004.

LORENZ, Federico. Resistências. In: SARMENTO-PANTOJA, Augusto; OLIVEIRA, Mara Rita Duarte de; SOUSA, Rosângela do Socorro Nogueira; CHABABO, Ruben (Orgs). Memória e Resistência: percursos, histórias e identidades. Rio de Janeiro: Oficina Raquel, 2012, p. 14-18.

LOWY, Michel. As aventuras de Karl Marx contra o Barão de Munchhausen: marxismo e positivismo na sociologia do conhecimento. 4. ed. São Paulo: Busca Vida, 1987.

LÜDERITZ, J. Relatório apresentado a Miguel Calmon Du Pin e Almeida, Ministro da Agricultura, Indústria e Comércio. Rio de Janeiro: Oficinas Gráficas da Lito/Tipografia Fluminense, 1925.

LUKÁCS, Georg. Sociologia. In: NETTO, José Paulo (Org.). Grandes cientistas sociais. São Paulo: Ática, n. 20, 1992.

As bases ontológicas do pensamento e da atividade do homem. Temas de Ciências Humanas. São Paulo, n. 4, 1978.

Prolegômenos para uma antologia do ser social: questões de princípios para uma ontologia hoje tornada possível. São Paulo: Boitempo, 2010.

MACHADO, L. R. S. Educação e divisão social do trabalho: contribuição para o estudo do ensino técnico industrial brasileiro. São Paulo: Cortez, 1982, 154 p.

MACHADO, Lucília. Trabalho-educação como objeto de investigação. Revista do NETE-UFMG, v. 14, n.2, jul./dez. 2005.

MALERBA, Jurandir (Org.). Teoria e história da historiografia. In: A história

escrita. Teoria e história da historiografia. São Paulo: Contexto, 2006, p. 11-26.

MANACORDA, Mário A. Introducción. In: GRAMSCI, Antonio. La alternativa pedagógica. Barcelona, Fontamara, 1981. 
MANFREDI, Sílvia M. Educação Profissional no Brasil. São Paulo: Cortez, 2002.

. Educação Profissional no Brasil: atores e cenários ao longo da história.

Jundiaí: Paco Editorial, 2016.

. Educação Sindical entre o conformismo e a crítica. São Paulo: Loyola, 1986.

MARTINS, Mônica. Entre a Cruz e o Capital: a decadência das corporações de ofícios após a chegada da família real (1808-1824). Disponível em: < $\underline{\text { http: / /www0.rio.ri.- }}$ gov.br/arquivo/pdf/obras_premiadas_pdf/entre_cruz_capitall.pdf $>$. Acesso em: jan. 2017.

MARX Karl. Prefácio à contribuição à crítica da economia política. In: Para a crítica da economia política; salário, preço e lucro; o rendimento e suas fontes. São Paulo: Abril Cultural, 1982.

MARX, Karl; ENGELS, Friedrich. A ideologia alemã (I - Feuerhach). São Paulo: Ciências Humanas, 1979.

A ideologia Alemã. São Paulo: Boitempo, 2007.

. A Ideologia Alemã. Tradução: Luís Cláudio de Castro e Costa. São Paulo: Martins Fontes, 1979.

MARX, Karl. O Capital. Crítica da economia política. v. 2. Rio de Janeiro: Civilização Brasileira, 1980.

. Contribuição à crítica da economia política. São Paulo: Estampa, 1977.

pular, 2008 .

. Contribuição à crítica da economia política. São Paulo: Expressão Po-

. Crítica à filosofia do direito de Hegel. São Paulo: Boitempo, 2005.

. Manuscritos econômico-filosóficos. São Paulo: Boitempo, 2004.

. O 18 Brumário e Cartas a Kugelman. 4. ed. Rio de Janeiro: Paz e Terra, . O capital. (Crítica da Economia Política). v. 2. Rio de Janeiro: Civilização Brasileira, 1980.

. Obras Escolhidas: em três tomos. Lisboa / Moscovo: Editorial “Avante!”Edições Progresso, 1982.

MASTROGREGORI, Mássimo. Historiografia e tradição das lembranças. In: MALERBA, Jurandir (Org.). A história escrita. Teoria e história da historiografia. São Paulo: Contexto, 2006, p. 65-94.

MATTOS, Ilmar Rohloff de. O império da boa sociedade. São Paulo: Atual, 1991.

Hucitec, 1990.

O Tempo saquarema. A formação do estado imperial. 2. ed. São Paulo:

MATTOS, Marcelo B. Trabalhadores e Sindicatos no Brasil. SP: Expressão Popular, 2009.

. Recuando no tempo e avançando na análise: novas questões para os estudos sobre a formação da classe trabalhadora no Brasil. In; GOLFMACHER, Marcela; MATTOS, Marcelo Badaró; TERRA, Paulo Cruz (orgs.). Faces do trabalho: escravizados e livres. Niterói: EDUFF, 2010, p. 11-26. 
. Trajetórias entre fronteiras: o fim da escravidão e o fazer-se da classe trabalhadora no Rio de Janeiro. Revista Mundos do Trabalho. v. 1, n. 1, jan./jun. 2009.

. Trabalho, classe trabalhadora e o debate sobre sujeito histórico ontem e hoje. In: NEVES, Renake Bertholdo David (Org.). Trabalho, estranhamento e emancipação. Coleção NIEP Marx, v.1. Rio de Janeiro: Consequência, 2015. p. 91-138.

MEDEIROS, Marluce. Expansão capitalista ensino industrial. Rio de Janeiro: SENAI/DN/DPEA, 1987.

MELLO, João Cardoso de. O capitalismo tardio. 4. ed. São Paulo: Brasiliense, 1986. MENDONÇA, Sonia R. A balança, a régua e o arado: sistemas de ensino e habitus de classe na Primeira República. Cadernos do ICHIF, Niterói: UFF, n. 71, 1992.

MÉSZÁROS, István. A educação para além do capital. São Paulo: Boitempo, 2005.

Para além do capital. São Paulo: Boitempo, 2002.

MICELI, P. Além da fábrica: o projeto industrialista em São Paulo, 1928-1948. São

Paulo: Federação das Indústrias do Estado de São Paulo, 1992.

MORAES, Carmen Sylvia V. de. A socialização da força de trabalho: instrução popular e qualificação profissional no estado de São Paulo (1873 - 1934). Bragança

Paulista: EFUSF, 2003.

MOURA, Clóvis. Rebelião na senzala: quilombos, insurreições, guerrilhas. Porto Alegre: Mercado Aberto, 1988.

MUSTÈ, Marcello. La storia: teoria e metodi. Roma: Carocci, 2005.

NAGLE, Jorge. Educação e sociedade na Primeira República. Rio de Janeiro: DP \& A, 2001.

NEGRO, Antonio L.; GOMES, Flavio. Além de senzalas e fábricas. Uma história social do trabalho. Tempo Social, Revista de Sociologia da USP, São Paulo, v.18, n. 1, p. 217-240, jun. 2006.

NETTO, José Paulo. Cinco notas a propósito de la "cuestión social". Temporalis, Brasília, n. 3, 2001.

NOGUEIRA, Marco Aurélio. O bode expiatório. Época, Editora Globo, São Paulo, p. 46-53, 19 jan. 2019.

NUÑEZ, Ivan. Investigación histórica en educación [s.l., s. n., s.d.]. Impresso.

ODÁLIA, Nilo. O tempo e a história. Tempo Brasileiro, Rio de Janeiro, n. 7, p. 5370, 1965.

OLIVEIRA, Milton Ramon. Formar cidadãos úteis: os patronatos agrícolas e a infância pobre na Primeira República. Bragança Paulista: EDUSF, 2003.

PALARO, Ricardo; BERNART'T, Maria de Lourdes. O trabalho como princípio educativo e como princípio de alienação: possibilidades e limites da pedagogia da alternância. Revista HISTEDBR On-line, Campinas, n. 46, p. 296-308, jan. 2012.

PETERSEN, Silva. Introdução ao estudo da história. Temas e textos. Porto Alegre: Edição do Autor, 2013.

PINSKY, Carla B. (Org.). Fontes históricas. São Paulo, Contexto, 2008.

PIQUETTY, Thomas. O capital no século XXI. A economia da desigualdade.

Rio de Janeiro: Intrínseca, 2015. 
PRADO JÚNIOR, Caio. Formação econômica do Brasil contemporâneo. São Paulo: Brasiliense, 1963.

. Formação do Brasil contemporâneo: Colônia. São Paulo: Brasiliense / Publifolha, 2000.

QUEIROZ, Maria Isaura P. de. Relatos Orais: do "indizível” ao "dizível”. Ciência e Cultura. v. 39, n. 3 , p. 14 - 43, 1987.

REIS, João J. Rebelião escrava no Brasil. A história do levante do malês em 1835. São Paulo: Cia das Letras, 1986.

RODRIGUES, José. O moderno príncipe industrial. O pensamento pedagógico da Confederação Nacional da Indústria. São Paulo: Autores Associados, 1998.

RODRIGUES, Neidson. Educação: da formação à construção do sujeito ético. Educação \& Sociedade, Revista Quadrimestral de Ciência da Educação, CEDES, Campinas, n. 76, Especial, p. 232-257, 2001.

ROMANELLI, Otaíza. História da Educação no Brasil: 1930-1973. Petrópolis: Vozes, 1978.

RÜSEN, Jörn. Como dar sentido ao passado: questões relevantes da meta-história. História da historiografia, n. 2, p. 163-209, mar. 2009.

Razão histórica: teoria da história: fundamentos da ciência histórica. Brasília, Editora da Universidade de Brasília, 2001.

SANFELICE, José Luís. A ciência da história e a história da educação. In: SIQUELLI, Sônia Aparecida et al. (Orgs.). Fundamentos da educação: compreensões e contribuições. Uberlândia: Navegando Publicações, 2017. Disponível em: < $\underline{\text { https: } / / \text { medi- }}$ a.wix.com/ugd/35e7c6 b40cee8f4bda47f1b55b7c8af5fa5a12.pdf >. Acesso em: 15 jul. 2019.

SAVIANI, Dermeval. Breves considerações sobre fontes para a história da educação. Revista HISTEDBR On-Line, Campinas, n. especial, 2006.

Educação: do senso comum à consciência filosófica. São Paulo: Cortez /

Autores Associados, 1980.

História das ideias pedagógicas no Brasil. Campinas, SP: Autores Associados, 2007.

História das ideias pedagógicas no Brasil. Campinas, SP: Autores Associados, 2010.

. O trabalho como princípio educativo frente às novas tecnologias. In: FER-

RET'TI, Celso J. Novas tecnologias, trabalho e educação: um debate multidisciplinar. Petrópolis: Vozes, 1994.

. Sociologia e história da educação: aspectos da trajetória de um cientista militante. In: Revista Contemporânea de Educação, v. 8, n. 16, ago./dez. 2013.

SCHAFF, Adam. História e verdade. São Paulo: Martins Fontes, 1978.

SCHWARZ, Robert. As ideias fora de lugar. Estudos CEBRAP, São Paulo n. 3, 1973.

SILVA, Adriana Maria P. da. Aprender com perfeição e sem coação. Uma escola para meninos pretos e pardos na corte. Brasília: Editora Plano, 2000. 
SILVA, Eduardo; REIS, José João. Negociação e conflito, a resistência negra no Brasil escravista. São Paulo: Cia das Letras, 1989.

SILVA, Rogério Forastieri da. História da historiografia. Capítulos para uma história das histórias da historiografia. Bauru, SP: EDUSC, 2001.

SLENES, Robert. Na senzala uma flor: as esperanças e recordações na formação da família escrava. Campinas: UNICAMP, 1989.

SMITH, Adam. A natureza e causas da riqueza das nações: investigação sobre a natureza e suas causas. Os Pensadores. São Paulo: Abril Cultural, 1983.

SOARES, Luiz. C. A manufatura na formação econômica e social escravista no Sudeste. Um estudo das atividades manufatureiras na região fluminense, 18401880. 1980. 417 f. Dissertação (Mestrado em História) - Universidade Federal Fluminense, Rio de Janeiro, 1980.

THOMPSON, E. P. La formación de la classe obrera em Inglaterra. Barcelona: Editorial Crítica, 1989, tomos 1 e 2.

A formação da classe operária inglesa. A força dos trabalhadores. Vol. III. Rio de Janeiro: Paz e Terra, 1987.

TITTON, Mauro. O princípio educativo do trabalho e o trabalho enquanto princípio educativo: ampliando o debate com os movimentos de luta social. Disponível em: < http://www.anped.org.br/sites/default/files/gt09-4589-int.pdf >. Acesso em: 16 dez. 2018.

TORRES-RIVAS, Edelberto. Respuesta de Edelberto Torres-Rivas. Encuesta sobre el pensamiento crítico em América Latina. Crítica y Emancipación, Revista

Latinoamericana de Ciencias Sociales, ano 1, n. 2, p. 20-22, Primer semestre 2009.

TRAVERSO, Enzo. Il secolo armato. Interpretare le violenze del Novecento.

Milano: Feltrinelli, 2012.

La escritura de la historia entre literatura, memoria y justicia. Actuel Marx /

Intervenciones, Universidad Bolivariana, Santiago, Chile, n. 6, p. 13-26, Primer semestre 2008.

TSÉ-TUNG, Mao. Sobre a contradição. In: TSÉ-TUNG, Mao. Sobre a Prática e Sobre a Contradição. 2 ed. São Paulo: Expressão Popular, 2001. p.37-95.

TURAZZI, Maria Inez. A euforia do progresso e a imposição da ordem. A engenharia, a indústria e a organização do trabalho na virada do século XIX ao XX. São Paulo: Marco Zero / Rio de Janeiro: COPPE, 1989.

VILAR, Pierre. Iniciação ao vocabulário da análise histórica. Lisboa: João de Sá da Costa, 1985.

Pensar la historia. México, DF: Instituto Mora, 1992.

WEINSTEIN, Bárbara. (Reformação) da classe trabalhadora no Brasil (19201964). São Paulo: Cortez/EDUSF, 2000.

ZEMELMAN, Hugo. Uso crítico de la teoria. En torno a las funciones analíticas de la totalidad. México, UNU/El Colegio de México, 1987. 


\section{SOBRE OS AUTORES}

\section{JACQUELINE BOTELHO}

Assistente Social pela Universidade do Estado do Rio de Janeiro (UERJ), Doutora em Serviço Social pela UERJ, Professora da Escola de Serviço Social da UFF, Coordenadora do NEPEC/UFF e membro do NEDDATE e do Grupo THESE - Projetos Integrados de Pesquisas em História, Trabalho, Saúde e Educação (UFF-UERJ-EPSJV-Fiocruz). botelho.jacque@gmail.com

\section{JORDAN RODRIGUES DOS SANTOS}

Bacharel e Licenciado em Ciências Sociais pela Universidade do Estado do Rio de Janeiro (UERJ); Professor de Sociologia da Rede de Educação Básica do Estado do Rio de Janeiro; Mestrando em Educação pela Universidade Federal Fluminense (UFF). jordansociologia@gmail.com

\section{LÍSIA NICOLIELLO CARIELLO}

Graduanda em História pela, Universidade Federal Fluminense (UFF), exBolsista de Iniciação Científica (PIBIC-UFF) do Projeto de Pesquisa "HISTORIOGRAFIA EM TRABALHO E EDUCAÇÃO E O PENSAMENTO CRÍTICO - Como se escreve a história da Educação Profissional" (2013-2017), Mestranda em História pela Universidade Federal Fluminense (UFF). lisiacariello@hotmail.com

\section{MARCELO LIMA}

Pedagogo pela Universidade Federal do Espírito Santo (UFES), Mestre em Educação pela UFES, Doutor e Pós Doutor em Educação pela Universidade Federal Fluminense (UFF), membro do comitê científico do GT09 da ANPED, do PPGE-UFES, do NEDDATE-UFF, do Grupo THESE (UFFUERJ-EPSJV-Fiocruz) e do LAGEBES-UFES. marcelo.lima@ufes.br

\section{MARIA CIAVATTA}

Licenciada em Filosofia, Doutora em Ciências Humanas (Educação), PUC-RJ, Professora Titular em Trabalho e Educação do Programa de Pós-graduação da Universidade Federal Fluminense; Coordenadora do Grupo THESE - Projetos Integrados de Pesquisas em História, Trabalho, Saúde e Educação (UFFUERJ-EPSJV-Fiocruz). mciavatta@,terra.com.br

\section{MÔNICA ROCHA}

Bacharel em Ciências Sociais pela Universidade Federal Fluminense, Especialista em História do Brasil pela Universidade do Estado do Rio de Janeiro (UERJ), Mestranda em Educação pela UFF. monrockaz@hotmail.com 


\section{RENATA REIS}

Doutora em Educação pelo Programa de Pós-graduação da Universidade Federal Fluminense (UFF); Professora da Escola Politécnica Joaquim VenâncioFiocruz (EPSJV-Fiocruz); Pesquisadora Associada do Grupo THESE - Projetos Integrados de Pesquisas em Trabalho, História, Educação e Saúde (UFFUERJ-EPSJV-Fiocruz). rbatistella007@gmail.com

\section{ROSÂNGELA ROSA}

Doutora em Educação pelo Programa de Pós-graduação em Educação - UFF; Mestre em Ciências pela FIOCRUZ; Professora do Programa de Pós-graduação em Ensino de Ciências do Instituto Federal de Educação, Ciência e Tecnologia do Rio de Janeiro (IFRJ). Integrante do Grupo THESE - Projetos Integrados de Pesquisas em Trabalho, História, Educação e Saúde (UFF-UERJEPSJV-Fiocruz). rosangelrosa@gmail.com

\section{SANDRA MORAIS}

Historiadora, Doutora em Educação pela Universidade Federal Fluminense (UFF). Atuou como Coordenadora de Educação à Distância da disciplina História na Educação na Universidade Federal do Estado do Rio de Janeiro (UNIRIO). É integrante do Neddate/UFF. Pesquisa nas áreas de trabalho, educação, crianças e adolescentes. E-mail: sandra.morais@globo.com

\section{SÂNIA NAYARA FERREIRA}

Licenciada em Pedagogia, pela Universidade Federal Fluminense (2016), aluna do curso de Mestrado em Educação (UFF), participante do Grupo THESE Projetos Integrados sobre Trabalho, História, Educação e Saúde (UFF UERJ - EPSJV/Fiocruz) e apoio técnico do Projeto de Pesquisa "HISTORIOGRAFIA EM TRABALHO E EDUCAÇÃO E O PENSAMENTO CRÍTICO - Como se escreve a história da Educação Profissional" (20132018), coordenado pela Profa. Dra. Maria Ciavatta. E-mail: sanianayara@,id.uff.br 
$\begin{array}{ll}\text { Formato } & 15,5 \times 23 \mathrm{~cm} \\ 1^{a} \text { Edição } & \text { Agosto de } 2019\end{array}$

Navegando Publicações

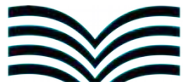

NAVEGANDO

www.editoranavegando.com editoranavegando@gmail.com

Uberlândia - MG

Brasil 


Resultado do projeto A Historiografia em TrabalhoEducação e o Pensamento crítico, este livro é uma obra coletiva coordenada pela Professora Maria Ciavatta. Discutindo preliminarmente a historiografia da relação entre trabalho e educação, a obra revisita oito estudos fundamentais representativos do pensamento crítico sobre educação profissional, formação para o trabalho e escolarização dos trabalhadores.

Nesses tempos em que vivemos no Brasil uma verdadeira "democracia suicida" com as próprias instituições ditas democráticas golpeando o Estado Democrático de Direito pela ação articulada da grande mídia, do parlamento e do judiciário, este livro, ao difundir o pensamento crítico, insere-se na luta contra os retrocessos em curso.

Trata-se de uma luta longa e difícil porque democracia suicida significa precisamente: o povo iludido por falsas promessas, no exercício de sua soberania vota contra si mesmo elegendo seus próprios algozes. Recomendo, pois, enfaticamente a leitura desta obra como antídoto às ilusões ideológicas difundidas pela mídia tradicional e pelas redes sociais reforçando, assim, a mobilização para reconstruir nossa jovem democracia destruída quando ainda buscava se consolidar.

São Paulo, 25 de março de 2019.

Dermeval Saviani, Professor Emérito da UNICAMP e Pesquisador Emérito do CNPq.

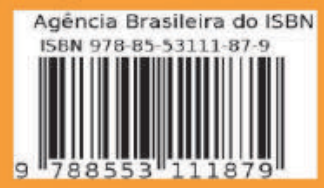

